\title{
'At the heart of the matter': A comparative analysis of youth justice transformation between New Zealand and South Africa
}

\author{
By \\ Ashley Fritha Shearar
}

A thesis

Submitted to the Victoria University of Wellington in fulfilment of the requirements for the degree of Doctor of Philosophy

Victoria University of Wellington

2013 


\section{$\underline{\text { Table of Contents }}$}

Abstract $\quad$ ix

Key words $\quad$ xi

Acknowledgements $\quad$ xi

Acronyms $\quad$ xii

Chapter 1

Introduction 1

Motivation for study $\quad 2$

$\begin{array}{ll}\text { Research approach } & 3\end{array}$

$\begin{array}{ll}\text { Structure of the thesis } & 4\end{array}$

$\begin{array}{ll}\text { Key findings } & 7\end{array}$

$\begin{array}{lr}\text { Terminology } & 8\end{array}$

Chapter 2

$\begin{array}{lr}\text { Methodology } & 9\end{array}$

$\begin{array}{lr}\text { Comparative case studies } & 9\end{array}$

$\begin{array}{lr}\text { Phenomenological research } & 14\end{array}$

$\begin{array}{lr}\text { Data collecting } & 15\end{array}$

$\begin{array}{lr}\text { Ethical considerations } & 16\end{array}$

$\begin{array}{ll}\text { Overcoming challenges } & 16\end{array}$ 


\section{Chapter 3}

\section{The history of race relations in New Zealand and South Africa}

that influenced changes to their youth justice systems

New Zealand

The Treaty of Waitangi

A policy of assimilation

Māori resistance

Uncovering the experience of Mäori in the child welfare system

Setting up the Ministerial Advisory Committee on a Māori Perspective for the Department of Social Welfare

South Africa

Apartheid

A policy of separation

African resistance

State retaliation against children involved in the struggle 33

$\begin{array}{ll}\text { Civil society starts to take notice } & 35\end{array}$

Civil society starts to consider solutions for children in conflict with the law 37

Conclusion

Chapter 4

The impact of adversity on children and youth development

The ecological approach to human development

Developing healthy attachment

Broader social influences 


\section{Chapter 5}

Youth justice transformation in New Zealand and South Africa

New Zealand

Previous legal provisions for children in conflict with the law in New Zealand 51

Exposing concerns around child abuse and neglect in New Zealand 52

Identifying the shortcomings in New Zealand's child welfare system 54

Two emerging schools of thought to address child welfare needs

Recasting the draft child welfare legislation 57

Incorporating the justice approach $\quad 59$

The influence of pilot projects in the Family Court 61

Establishing the new youth justice jurisdiction 64

The Department of Justice considers the Māori perspective 65

Designing the FGC process for youth justice 66

$\begin{array}{lr}\text { South Africa } & 69\end{array}$

Previous legal provisions for children in conflict with the law in South Africa 69

Ongoing abuse of children in the criminal justice system 70

Key political activists become part of the new South African government 73

Tapping into the New Zealand experience 74

Establishing diversion from criminal proceedings as a credible option 78

The Inter-Ministerial Committee for Young People at Risk 79

Formalising the law making process

$\begin{array}{lr}\text { Establishing the core principles and practice } & 83\end{array}$

Promoting the Child Justice Bill 83

$\begin{array}{lr}\text { Preparing for Parliament } & 85\end{array}$

Bifurcation stalls the process

Key role players keep the original principles alive 88

The government revisits the Child Justice Bill 90

The Child Justice Bill becomes law 99 
Comparing the processes of youth justice transformation between New Zealand and South Africa

$\begin{array}{ll}\text { Legislative comparisons } & 94\end{array}$

Alarm at abuses against children 96

Addressing gaps in policy and legislation 97

Working through ideological tensions 98

The political will of key government officials facilitated the changes 100

Comprehensive recasting of legislation to ensure it met the intended values and principles

$\begin{array}{lr}\text { Consultation } & 101\end{array}$

$\begin{array}{ll}\text { Piloting projects to find credible solutions } & 103\end{array}$

$\begin{array}{ll}\text { Conclusion } & 104\end{array}$

Chapter 6

$\begin{array}{lr}\text { Implementation } & 106\end{array}$

$\begin{array}{ll}\text { Implementing agencies } & 106\end{array}$

$\begin{array}{ll}\text { New Zealand } & 106\end{array}$

$\begin{array}{ll}\text { Police } & 106\end{array}$

$\begin{array}{ll}\text { Social Development } & 108\end{array}$

$\begin{array}{ll}\text { Courts } & 110\end{array}$

$\begin{array}{ll}\text { South Africa } & 112\end{array}$

\begin{tabular}{ll} 
Police & 112 \\
\hline & 113
\end{tabular}

Social Development 113

$\begin{array}{lr}\text { Courts } & 117\end{array}$

$\begin{array}{ll}\text { Challenges of Implementation } & 120\end{array}$

$\begin{array}{lr}\text { Practitioners } & 120\end{array}$

$\begin{array}{ll}\text { Staff training } & 126\end{array}$

$\begin{array}{lr}\text { Quality and Accessibility } & 128\end{array}$

$\begin{array}{ll}\text { Conclusion } & 131\end{array}$ 


\section{Chapter 7}

How international standards for children's rights are evident in

New Zealand and South African youth justice systems

The development of international standards for children's rights

International standards for the rights of children in conflict with the law

The influence of international standards for children's rights and youth justice on New Zealand and South African youth justice systems

Ratifying the UNCRC

Age of criminal capacity and children's evolving capacity

Due process

Diverting children and young people from criminal proceedings

Conclusion

\section{Chapter 8}

\section{Restorative justice principles in New Zealand and South Africa's} youth justice systems

Defining restorative justice

Involving families and communities in restorative justice processes

Restorative justice approaches strengthen compliance with international standards for youth justice

Restorative justice provisions in New Zealand and South Africa's youth justice systems 
Conclusion

Chapter 9

How social entrepreneurship contributed to youth justice

transformation in New Zealand and South Africa

Characteristics of the social entrepreneur

Joining forces to effect change

State support for social entrepreneurial ventures

Generational handover

Conclusion

Chapter 10

How policy transfer contributed to youth justice transformation in New Zealand and South Africa

Defining policy transfer

'Perfect' versus 'bounded' rationality

Conclusion

Chapter 11

Conclusion

Postscript

Appendix 1

Appendix 2

Appendix 3

Appendix 4

Bibliography 


\section{Abstract}

During the mid-1980s, Māori families challenged New Zealand's social welfare system, reclaiming their right to be involved in decisions about their children. Around the same time, parents and community groups protested the detention of hundreds of children in South Africa during the Apartheid era. These experiences helped shape both countries' youth justice systems, which reflect restorative justice principles and international standards for children's rights.

The research reported here is the first in-depth comparative analysis to compare New Zealand and South Africa's journeys to alter their youth justice systems. It asks the following key questions:

- What were the key conceptual influences that shaped youth justice transformation in New Zealand and South Africa?

- What do both countries' experiences of youth justice transformation reveal about the role of individuals, advocacy coalitions, and international influences in shaping policy and practice?

Using a phenomenological research approach, key role players from both countries were interviewed. These interviews discovered that social entrepreneurial factors gave direction to policy outcomes. All participants described their commitment to changing the status quo following their exposure to the inhumane conditions experienced by children and young people in conflict with the law. This prompted them to promote policies that diverted children from the justice system and prevented re-offending while still holding children to account for their behaviour and encouraging them to repair the harm. The participants explained their motivation to find policy solutions that empowered children, families, and victims. In both countries, social entrepreneurs resisted opposition and joined forces to develop convincing arguments for their position. This research confirmed the advantages of government support to advance social entrepreneurial ventures.

Policy transfer was also found to play a role in the change processes in both countries. This study identifies how both New Zealand and South Africa have lent their policies internationally to contribute to practical youth justice changes in countries seeking to adhere to international standards and to incorporate restorative justice principles. Significant contributions include New Zealand's family group conference, which has inspired several 
jurisdictions, as well as South Africa's diversion programmes, which have particularly benefitted other African countries.

\section{Key Words}

Child justice; International children's rights; Policy transfer; Race relations; Restorative justice; Social entrepreneurship; Social justice; Youth development; Youth justice 


\section{Acknowledgements}

First, I would like to acknowledge my supervisors, Karen Baehler and Gabrielle Maxwell. Karen, your sound academic expertise and objectivity have helped to test my thinking as well as consider the broader contributions this thesis can make to the field of policy making beyond the areas of youth justice, children's rights and restorative justice. I am very grateful for your gentle guidance which has given me the confidence to explore unfamiliar territories. Gabrielle, your involvement in this project has been a privilege, both as a participant and as a mentor. Thank you for believing in what I was trying to achieve from the beginning and for your motivation and inspiration.

Thanks to Victoria University's School of Government, in particular Amanda Wolf and Dawn Yeabsley, for providing ongoing administrative and technical assistance. I would also like to thank Bill Ryan for his encouragement and assistance during the final stretch.

Thanks to all the research participants who, by sharing openly, made this study possible. Your commitment to the cause triggered my interest in this field, influenced my thinking and served as an inspiration. It has been an honour to capture some of your stories in order to bring to life this important piece of history. This thesis is a debt of gratitude to you for what you have contributed to me personally and to this movement in general.

I would like to thank my family for their ongoing warmth, support and interest in my thesis, as well as for listening to my ideas, even from very far away.

Last but not least, I would like to thank Wayne for his patience, understanding and encouragement throughout this thesis. 


\section{Acronyms}

ACORD - Auckland Committee on Racism and Discrimination

ANC - African National Congress

CJA - South African Child Justice Act of 2008

CLC - University of the Western Cape Community Law Centre

CODESA - Convention for a Democratic South Africa

CYPF Act - New Zealand Children, Young Persons and their Families Act of 1989

DCI - Defence for Children International

DPSC - South African Detainees Parents Support Committee

DSD - South African Department of Social Development

FGC - Family Group Conference

IMC - South African Inter-ministerial Committee for Young People at Risk

NACPAN - New Zealand National Committee for the Prevention of Child Abuse and Neglect

NCRC - National Committee on the Rights of the Child

NGO - Non-Governmental Organisation

NICRO - South African National Institute for Crime Prevention and the Reintegration of Offenders

PAC - Pan Africanist Congress

SALRC- South African Law Reform Committee

TRC - South African Truth and Reconciliation Commission

UN - United Nations

UNCRC - United Nations Convention on the Rights of the Child

UNDP - United Nations Development Programme 
VOM - Victim-Offender Mediation

WARAG - Women against Racism Action Group

YES - Youth Empowerment Scheme 


\section{Chapter 1}

\section{Introduction}

The ecology of human development is really a study of how a whole society functions to raise the children who will eventually take their place within that society.

Garbarino (1982:17)

The socio-economic upheaval of recent years has devastated many communities as they face growing poverty and lack of opportunity. Individuals and families around the world are trying to adapt to their worsening circumstances while governments consider how to make the most of existing resources and implement cost cuts to a number of services (Lundberg \& Wuermli, 2012). In many cases, this has exacerbated the social exclusion of already marginalised social groups (Lundberg \& Wuermli, 2012). Children and young people in these communities risk becoming increasingly vulnerable or hopeless about their futures (International Juvenile Justice Observatory, 2012). Several studies have raised concern about the links between intergenerational social exclusion and offending behaviour by children and young people. ${ }^{1}$ To prevent this trend, it is evident that strategies to reduce offending should address the impact of these negative social experiences and create environments that will encourage children and young people to become pro-social, well-integrated citizens (International Juvenile Justice Observatory, 2012).

In 1989, the United Nations Convention on the Rights of the Child (UNCRC) became the most influential international instrument to compel nations to take into account children's vulnerability, voice and role in society when designing systems and policies to address their needs. It included the rights of children in conflict with the law, which aimed to limit children's exposure to the criminal justice system by involving families and communities in their reintegration while still holding them to account for their actions and preventing further offending. ${ }^{2}$ From the late 1980's, around the same time the UNCRC was launched, restorative justice theory started to attract interest. It offered a set of principles that could help

\footnotetext{
${ }^{1}$ Chapter 4 discusses various theories on the causes of offending by children and young people. It highlights the social factors that contribute to this behaviour evident in New Zealand and South Africa's histories of social injustice and exclusion.

${ }^{2}$ Chapter 7 discusses the evolution of children's rights instruments, looking at their general relevance to youth justice, as well as youth justice provisions and instruments more specifically.
} 
to guide responses to the complex needs of children who offend. These principles support children and young people to understand the impact of their offending and take responsibility for their criminal behaviour, while involving both victims and offenders in finding solutions to repair the harm caused by the offending with adequate guidance. ${ }^{3}$

Over the past two decades, many countries have been considering how best to incorporate and combine children's rights and restorative justice principles into their youth justice systems. ${ }^{4}$ This research contributes to the evolution of this global youth justice movement by tracing and comparing New Zealand and South Africa's journeys to alter their existing youth justice systems to reflect international standards for children's rights and restorative justice principles. While aspects of these countries' youth justice systems have been well documented, this is the first in-depth comparative analysis of youth justice transformation between the two countries. It is told from the perspective of key individuals responsible for advancing the new approach to their youth justice systems, which, in both cases, emerged from a need to respond to the effects of more general social injustices affecting children and young people in conflict with the law.

\section{Motivation for study}

Soon after becoming involved in youth justice, I learned of New Zealand's influence on South Africa's process of youth justice system change. In November 2002 I was enrolled in a course at the University of Cape Town in Probation and Correctional Practice. The head of the course enthusiastically explained how South African policy makers were developing a new youth justice system underpinned by restorative justice principles. He suggested I watch a video on family group conferences (FGC) illustrating how restorative justice principles were being applied in New Zealand. At first, I questioned whether South Africa had the capacity to apply New Zealand's restorative justice approach, particularly while the new nation was still struggling to extract itself from the shadows of its recent apartheid history.

In February 2003, I attended the first round of hearings on South Africa's Child Justice Bill of 2002, heard before South Africa's Portfolio Committee for Justice and Constitutional Development. I observed how child justice lobbyists and policy makers had united around their submissions in support of a new system that promoted children's rights and restorative justice principles. However, by the end of the hearings, the head of the Committee had

\footnotetext{
${ }^{3}$ Chapter 8 discusses restorative justice theory and identifies links to the UNCRC.

${ }^{4}$ This includes countries from most continents since the signing of the UNCRC in 1989.
} 
stymied their cause, primarily due to his concerns about the high rate of serious violent crime in South Africa which he believed required a more retributive response. While South Africa's Child Justice Bill came to a stalemate in Parliament, the key activists did not compromise on their principles. Instead, they continued to garner support for their approach as widely as possible which became a common language for most South Africans involved in child justice (including practitioners), despite the absence of a holistic legal framework. I became intrigued by the tenacity of individuals who were responsible for driving youth justice changes in South Africa and their steadfast commitment to the principles, despite significant hurdles and opposition.

After moving to New Zealand in early 2006, I started looking into New Zealand's history of the development of the Children, Young Persons and their Families Act of 1989. I was struck by two things in particular. One was the similar contextual issues and challenges that New Zealand faced in the development of its youth justice system, ${ }^{5}$ the other was that the key role players in New Zealand who drove their transformational youth justice system during the 1980s appeared to share similar qualities to the key South African role players, particularly in terms of their commitment to a similar set of core principles that resonated with restorative justice and international standards for children's rights. This discovery helped to give direction to my research approach.

\section{Research approach}

This research provides a comparative, socio-historical account of the intertwined stories of youth justice transformation in New Zealand and South Africa, by using a qualitative, interpretive methodology. A combination of literature, documentation, archival records and interviews with individuals who drove youth justice system changes in both countries were investigated to respond to the following research questions:

- What were the key conceptual influences that shaped youth justice transformation in New Zealand and South Africa?

- What do both countries' experiences of youth justice transformation reveal about the role of individuals, advocacy coalitions and international influences in shaping policy and practice?

\footnotetext{
${ }^{5}$ Part II of this thesis unpacks the history of youth justice transformation in both countries and highlights the comparisons related to social context and challenges.
} 
These additional questions helped guide the study:

- What core concepts are manifested in the youth justice policy and legislation produced in the two countries?

- How did these concepts enter the policy arena, and how were they turned into practical realities?

- How effective has the practical implementation of the reforms been?

- What forces challenge youth justice transformation and how are these forces managed in the two countries?

The common stories that emerged through this process became the building blocks from which to construct the historical narrative of the events that led to the changes to the youth justice systems in New Zealand and South Africa. In addition to using the stories to construct the historical account, key themes surfaced from the reconstruction of events, which helped to build the theoretical framework from the findings. The themes were either related to the core principles that influenced the youth justice system designs in both countries or to specific public policy processes which enabled the youth justice changes in both countries.

\section{Structure of the thesis}

Chapter 2 describes the methodology chosen to develop the cases and to triangulate the findings using interviews, documents and archival records. An elite group of twenty-one key role players were purposefully selected to participate in the research due to their contribution to youth justice transformation in both countries. A phenomenological research approach was chosen, using in-depth interviews to expose layers of insight into the participants' particular roles in swaying the youth justice system changes in both countries.

The research approach and findings guided the structure of the thesis, which has been divided into two parts to shape the dialogue between the cases. Below is an outline of the chapters divided in two parts to help map out the thesis structure.

\section{Part I-The cases}

Part I sets out the historical account of the cases. It discusses the relevant contextual factors, policy drivers, challenges and resulting youth justice changes. Chapter 3 identifies common historical strands that created a backdrop for youth justice changes in both New Zealand and South Africa. The focus of this Chapter is on how colonial powers in both countries eroded 
indigenous family structures and local customs, creating racial tensions which increasingly angered indigenous populations over time. How these tensions led to resistance from indigenous people in both countries is discussed, highlighting actions taken to end state control and abuse of their children in government institutions. In order to demonstrate the impact of the histories of social injustice on children and young people in both countries, Chapter 4 presents a selection of theories which emphasise the importance of social relationships in guiding pro-social development. These theories illuminate how negative social experiences, such as those experienced by indigenous children in New Zealand and South Africa, can often result in anti-social or criminal behaviour by children and young people. Such behaviour can further alienate them from society and draw them into the criminal justice system - as became evident in the over-representation of indigenous children and young people in state institutions in both countries prior to the changes.

Chapter 5 gives an in-depth account of how New Zealand's Children Young Persons and their Families Act of 1989 (CYPF Act) and South Africa's Child Justice Act of 2008 (CJA) ${ }^{6}$ were engineered to address these problems. It reveals the similarities in the development of each country's youth justice systems, and shows how a combination of community activism, the commitment of critical policy makers and advocates, international influences and government support created youth justice systems aimed at improving outcomes for children in conflict with the law, particularly indigenous children. Chapter 5 explains how this was achieved by limiting children and young people's exposure to the criminal justice system through keeping them in the care of families and communities wherever possible and supporting them to make amends for their offending and learn from their behaviour. Chapter 6 describes the mechanisms each country put in place to implement their new youth justice legislation and reveals some of the common challenges they faced in turning visionary policy into practice.

\section{Part II - Theories, patterns and lessons}

Part II provides a critical analysis of youth justice transformation between New Zealand and South Africa in relation to the theoretical framework that emerged from the research findings. It identifies theories emerging from the historical narrative and provides a comparative analysis of both countries' experiences in relation to the theories. While international standards and restorative justice underpin the youth systems, social entrepreneurship and

\footnotetext{
${ }^{6}$ The Child Justice Bill became an Act in 2008. This will be explained further in the thesis.
} 
policy transfer help to describe the factors that advanced the development of these systems. One set of theoretical frameworks explains the content of the reforms; the other set unpacks the process by which the ideas became realities/policy. This thesis is the story of the interaction between ideas, people and institutional processes.

Chapter 7 considers the relevance of the children's rights-based approach to youth justice changes in New Zealand and South Africa. It traces the evolution of international standards for children's rights, with a focus on youth justice standards. It discusses the extent to which these rights shaped the development of New Zealand and South Africa's youth justice systems and then considers each country's commitment to upholding these standards. Chapter 8 looks into how restorative justice principles are manifested in New Zealand and South Africa's youth justice policies, including how these principles are applied in youth justice practice. It also looks at some of the challenges to implementing these principles, particularly demonstrating how drawing on indigenous justice practices and customs can both advance the restorative justice agenda as well as cause tension. Together, Chapters 7 and 8 focus on the points of convergence between international standards for children's rights and restorative justice principles that were found to underpin youth justice system design in both countries. These are:

- the importance of community empowerment and cultural responsiveness;

- the involvement of communities and families in key decision-making and in supporting children and young people's reintegration;

- keeping children out of the criminal justice system;

- holding young people to account; and

- repairing harm

Chapter 9 explains how social entrepreneurship can serve as a vehicle for social policy change and reveals the social entrepreneurial characteristics of the research participants that strengthened their motivation to transform the existing youth justice systems. Chapter 10 looks at the ways in which policy transfer contributed to the youth justice system designs in New Zealand and South Africa, including the significance of both countries lending their policies to other countries interested in incorporating similar principles in to their youth justice systems. 


\section{Key findings}

This is the first in-depth, socio-historical comparative analysis of youth justice transformation between New Zealand and South Africa, told from the perspective of key role players who helped shape their youth justice systems into approaches that have generated interest around the world. The research found that not only are there strong similarities between the principles underpinning New Zealand and South Africa's youth justice systems, but that both countries had comparable policy making experiences. These experiences resulted in two youth justice systems with common ambitious objectives to repair harm caused by offending, reduce re-offending by children and young people, keep children and young people out of the criminal justice system and empower victims, children, families and communities.

Significantly, both countries' youth justice changes occurred within the context of more general social unrest which raised the profile of marginalised, indigenous communities striving to claim their rights to self-determination from the state.

The in-depth interviews with key role players found that a majority of them possessed social entrepreneurial qualities which added impetus to the policy changes both in New Zealand and South Africa. Furthermore, this research also provides examples which can contribute to the policy transfer literature by identifying cases where similar policy transfer approaches were adopted in both countries to help shape their youth justice systems. While international policies, approaches and practices were drawn upon, local indigenous customs and practices were also found to inspire policy makers in both countries. From a policy transfer perspective, New Zealand and South Africa were found to be both borrowers and lenders of youth justice policy at some stage during their processes of policy transformation. It has already been well-documented that policy makers in South Africa were inspired by New Zealand's youth justice approach due to its restorative nature and cultural sensitivity. This study also identifies how both New Zealand and South Africa have lent their policies internationally to contribute to practical youth justice changes in countries seeking to adhere to international standards and to incorporate restorative justice principles. Significant contributions include New Zealand's family group conference (FGC) innovation, which has inspired several international jurisdictions, and South Africa's approach to diversion which has particularly benefitted other African countries. The common experiences and challenges both countries faced when trying to convert ambitious policy into day-to-day practice provides useful lessons that can assist other countries borrowing from New Zealand and South Africa when trying to implement similar youth justice systems. 
The study is also interdisciplinary. Mansilla (2004:17) explained that there are three key factors which contribute to the success of an interdisciplinary study:

1. The degree to which new insights relate to the antecedent disciplinary knowledge in multiple disciplines involved;

2. The sensible balance reached in weaving disciplinary perspectives together; and

3. The effectiveness with which the integration of disciplines advances understanding and inquiry.

The research both drew from and contributes to the fields of public policy and administration, international law, youth justice and social development.

\section{Terminology}

Various terms exist for children and youth in the criminal justice system including youth, juveniles, children and young persons. While these terms are mostly used interchangeably in the general parts of the thesis, when considering them within either the New Zealand or the South African contexts specifically, they have definite age defined meanings that were carefully selected as part of the developments of the respective youth justice systems. In New Zealand a child in the criminal justice system is aged between 10-13 years and a young person is above 14 and under 17 years at the date of the alleged offending. In South Africa a child in the criminal justice system is aged between $10-18$ years. These age bands have implications for the way individuals are treated within their respective systems. Therefore, when discussing New Zealand's system, the terms 'children' and 'young persons' are used and when discussing South Africa's system the term 'children' is used. 


\title{
Chapter 2
}

\section{Methodology}

\begin{abstract}
A particular policy is simultaneously a historical narrative, a portrayal of particular motives and intentions at work in a particular setting, an account of prevailing ethical and moral standards at work on political and social life at some moment in history and an exercise in defining political and social reality for policy makers and the public.
\end{abstract}

(Ashford, 1992:4)

The thesis provides a historical narrative of the events that transformed New Zealand and South Africa's youth justice systems, along with new insights into youth justice policy changes in these different contexts which reflect similar drivers, values and principles. A phenomenological methodology was chosen for collecting data, which included in-depth interviews with a purposefully selected group of research participants. Participants were identified based on their role in developing and promoting the changes to each country's youth justice systems. Collectively, the inter-subjectivity revealed through their stories (Henning, 2004) illustrates the common contexts, catalysts for change and challenges to changing the youth justice systems in both countries, as presented in Part I. This then allowed for comparisons to be drawn between the two cases and to identify overarching theories, patterns and lessons that emerged, as discussed in Part II.

\section{Comparative case studies}

Using the comparative case study approach, this thesis draws on the findings to construct the historical accounts of youth justice changes and to analyse how both countries experiences contribute to theories relevant to international youth justice policy and system frameworks. According to Yin (1984:13), case studies are the "preferred strategy when 'how' and 'why' questions are being posed" which can be "invaluable in adding to understanding, extending experience and increasing conviction about a subject" (Stake in Gray 2004:123). Comparative case studies can be complicated when trying to draw parallels between what may appear to be vastly different contexts. To manage the contextual differences and make meaningful comparisons between the selected cases, Warwick advises that "if we work out principles of operational definitions in accord with the variety of social goals and meanings to which these 
dimensions are related, one society is comparable to any other society" (Warwick, 1973:120). This strategy has been used to compare the stories of youth justice transformation in New Zealand and South Africa.

Case studies rely on multiple sources of information (Patton in Gray, 2004: 131) in order to build up the cases being analysed (Gillham, 2000:22). Yin (1984:78) proposes six main sources of evidence for case studies: "documents, archival records, interviews, direct observation, participatory observation and physical artefacts". The main sources of information used for this research were documents, archival records and in-depth interviews in order to put together the story and to triangulate the findings.

\section{$\underline{\text { Documents and archival records }}$}

According to Yin (1984:81), "documents play an explicit role in any data collection in doing case studies". Secondary data analysis of strategies, policy papers, reports, letters, legislation and related discussion papers were examined to explore the sequence of events and critical influences in the processes of building new youth justice systems in South Africa and New Zealand. Documents and archival records included policy papers, national strategies, discussion papers and pieces of legislation relevant to youth justice; most notably Section 4 of New Zealand's Children, Young Persons and their Families Act of 1989 and South Africa's Child Justice Act of 2008. These documents and archival records also helped to expose some of the important theoretical underpinnings and concepts that inspired the direction and the design of the new youth justice systems in both countries. The thesis also refers to empirical studies conducted in New Zealand and South Africa which are woven into the discussion to highlight the factors that either promote or inhibit success of the new youth justice systems in each context.

Relevant secondary sources for New Zealand were accessed through the Victoria University Library and New Zealand Archives. In South Africa, secondary sources were accessed from the Library at the Institute of Criminology, the Manuscripts and Archive Department at the University of Cape Town and the Community Law Centre at the University of the Western Cape. Many documents for both countries were downloaded from the internet where available. Some participants also provided copies of documents from their personal records and collections. 


\section{$\underline{\text { In-depth interviews }}$}

Merriam (in Henning, 2004: 41) asserts that "a case study design is employed to gain an indepth understanding of the situation and meaning for those involved". In order to gain this understanding, open-ended interviews were conducted with key people involved in the conceptualisation, design, development and promotion of New Zealand and South Africa's current youth justice systems. Gillham (2000:64) refers to this strategy as "elite interviewing...when you interview someone in a position of authority or especially expert or authoritative people who are capable of giving answers with insight and a comprehensive grasp of what you are researching". Therefore, the participants selected were similar in that they each had a particular role and responsibility in shaping the new youth justice systems in both countries (Greef, 2002). They included policy makers, academics and individuals involved in youth justice within government and non-government sectors as well as key members of government responsible for helping to progress the pieces of legislations pertaining to youth justice. This allowed for the data to be "systematically collected and meanings, themes and general descriptions of the experience analysed within a specific context" (Greef, 2004:273). The research sought to discover what motivated and sustained these role players to successfully pursue their visions. Of key interest were the experiences, influences, values and traits that motivated the role players both individually and collectively. Given that the method involved 'elite interviews', the selection process was purposive.

The review of documents and archival records first helped to identify prominent role players who assisted the progress of the youth justice systems in New Zealand and South Africa. The researcher also knew and had access to some of the key role players, particularly from briefly working in the youth justice sector in South Africa. This made it possible to build up an initial list of participants. As the story took shape, new participants were identified. While some participants were aware of other informants being interviewed, there was no evidence that they discussed their interviews with each other beforehand. This helped to ensure that each participant's recall of the events being researched and their personal perspectives were not influenced by another participant's point of view, which could have compromised the triangulation of findings from the different interviews.

Yin (1984:69) believes that "the investigator must cater to the interviewees schedule and availability". A total of 21 open-ended interviews were conducted in situ in both South Africa and New Zealand. Participants were sent a letter via email explaining the background and 
purpose of the study and were invited to participate in an interview (attached as Appendix 1). Not all key role players who were involved in the process of youth justice transformation could be accessed. In these cases, their positions and roles have been described in the narratives using secondary data sources and via the accounts of various informants. Arrangements to meet were made via phone and email. All participants who could be contacted agreed to be interviewed. While they did not make up the total cohort, they were found to represent a significant group of key role players with critical roles in advancing youth justice policies in both countries. Participants interviewed were: ${ }^{7}$

\section{New Zealand:}

* Donna Hall - Member of the Ministerial Advisory Committee on a Māori Perspective for the Department of Social Welfare.

* Jacky Renouf - Chairperson for the Working Party on the Review of the Children and Young Persons Bill in 1987.

* Mike Doolan - Former National Director of Youth Services for the Department of Social Welfare and policy lead for youth justice for the Review of the Children and Young Persons Bill in 1987.

* Judge David Carruthers - Former Principal Youth Court Judge

* Dr Ian Hassall - First Children's Commissioner.

* John Angus - Former Children's Commissioner involved in the implementation of the Children Young Persons and their Families Act of 1989.

* Dr Gabrielle Maxwell - Researcher and advocate for youth justice family group conferences and restorative justice at Victoria University.

* Robert Ludbrook - New Zealand children's rights activist previously working for the Auckland Committee on Racism and Discrimination (ACORD).

* Judge Andrew Becroft - Current Principal Youth Court Judge and lawyer at the time the Children, Young Persons and their Families Act of 1989 came into force.

\footnotetext{
${ }^{7}$ Descriptions of the participants' roles are limited to their key positions in relation to the process of youth justice transformation. The thesis provides further description on their positions and involvement however, it does not describe other substantive roles these participants may have held outside of the youth justice transformation movement.

* According to Rosemary Shapiro-Liu, Dr Ann Skelton and Don Pinnock were also committee members of the Government and Non-Profit Organisations' Interdepartmental Committee for Diversion.
} 


\section{South Africa:}

* Rosemary Shapiro-Liu (Shapiro) - Former National Manager: Restorative Justice at the National Institute for Crime Prevention and Reintegration of Offenders (NICRO) and later National Director of Fundraising, Marketing and Media.*

* Dr Ann Skelton - Former member of Lawyers for Human Rights and current Director of the Centre of Child Law at the University of Pretoria

* Don Pinnock - Former Head of the Institute of Criminology at the University of Cape Town.

* Cheryl Frank - Director for the South African Institute for Security Studies, former Executive Director for RAPCAN and Justice Programme Director, Open Society Foundation for South Africa.

- Lukas Muntingh - Project Coordinator for the Civil Society Prison Reform Initiative (CSPRI) at the University of the Western Cape and former Deputy Executive Director for the National Institute for Crime Prevention and Reintegration of Offenders (NICRO)

* Dr Julia Sloth-Nielsen - Dean of Law at the University of the Western Cape and former manager of the Children's Rights Project at the Community Law Centre at the University of the Western Cape.

* Dr Jacqui Gallinetti - Former Project Coordinator for Child Justice Alliance and senior researcher for the Community Law Centre at the University of the Western Cape.

* Dr Roland Graser - Former Director of the South African National Institute for Crime Prevention and Reintegration of Offenders (NICRO) and former Head of Probation and Correctional Practice at the University of Cape Town's Department of Social Development.

* Yunus Carrim - Former Chairperson for the South African Portfolio Committee for Justice and Constitutional Development.

* Mike Batley - Executive Director for the Restorative Justice Centre in South Africa.

* Thulane Gxubane - Lecturer in Youth Justice and Probation and Correctional Practice at University of Cape Town, in South Africa.

* Researcher for the Portfolio Committee for Justice and Constitutional Development $^{8}$

\footnotetext{
${ }^{8}$ Requested to remain anonymous
} 


\section{Phenomenological research}

A phenomenological approach is interested in the subjective experience and interpretation of a situation from the perspectives of the selected participants (Lester, 1999). According to Henning (2004:37-38) the "phenomenological researcher believes that the participants can give their experience best when asked to do so in their own words... it is free and open, constrained only by the focus of the research question". Taking New Zealand and South Africa as examples, much has been written about their youth justice systems, including about some of the factors that contributed to the changes. However, the phenomenological approach allowed the researcher to explore the personal drivers and the human experiences in relation to the cases being studied. Gray (2004) explained that in order to conduct phenomenological research, the researcher must put aside any preconceptions of the phenomenon being explored to enable the results to provide "new meaning, fuller meaning or renewed meaning" (Gray, 2004:21). The findings from the interviews therefore exposed a novel and more personalised dimension to the story, not only from the individual experiences of each of the participants, but also by drawing on their inter-subjectivity and collective experiences.

A set of guided questions for the interviews was developed (attached as Appendix 2). While the guided questions were designed to provide some direction to the interviews, most of the discussions began by reminding the participants about the nature of the research, and then inviting them to tell their own stories in relation to the process of youth justice transformation in their countries. This generally led the participants to speak freely about their memories of their experience of youth justice transformation in their countries, as well as their views on the development, subsequent implementation, challenges and areas for improvement for the youth justice systems. According to Henning (2004:54), “The interviewer is a neutral facilitator who elicits the forthcoming information from the interviewee who gives these responses with the help of questions and prompts in an atmosphere of trust and accountability". Most of the interviews required minimal prompting, but probing questions were asked to reveal deeper insights in relation to the areas of exploration. In this sense, Henning (2004:57) would argue that the researcher and the participant become "coconstructors of the meaning" insofar as the researcher encourages the participants to expand on specific areas of interest through the prompts. The open-endedness of the discussions provided research data which was used to construct the historical narrative, identify the theoretical framework and conduct the comparative analysis. 
Two risks in using the phenomenological approach are (1) not being able to access the most appropriate participants, or (2) if access is gained, not eliciting open, frank engagement of the participants. If participants are not able to be accessed or have minimal interest in participating, data produced can be limited and unreliable. Fortunately, as discussed, most participants in this study could be accessed, were willing to participate and engaged openly in the interviews.

With the participants' consent the interviews were recorded using a digital voice recorder. All interviews were then transcribed verbatim by the researcher. This allowed the researcher to become more familiar with the material and to begin to recognise emerging patterns and themes for the analysis (Henning, 2004:76). The recall of events by all participants in both contexts was checked against the secondary data as well as the combination of interviews to be able to confirm accuracy and to piece together the picture for each country.

\section{Data collecting}

Yin (1984:79) refers to "three principles of data collection...[which] help to deal with problems of construct validity and reliability". These are:

a) Using multiple, not just single sources of information,

b) Creating a case study data base,

c) Maintaining a chain of evidence

According to Gillham (2000:13), given the concerns around construct validity and reliability when using the case study approach, the importance of using multiple methods is to find the points where the findings converge in order to determine their accuracy. Data collected from the documents, archival records and interviews was arranged according to the main themes that emerged. This created the narrative and provided the framework for discussion and analysis.

According to Gray (2004:143) "A form of time-series analysis is the use of chronologies, tracing events over time... chronologies not only allow for a description of events, but also for the analysis of causes". The interviews allowed for the historical narrative to be arranged chronologically in Part I of the thesis. This enabled comparisons between both countries to be drawn and analysed in terms of similar processes of change and motivations, as well as the challenges of turning policy into practice (Yin, 1984). Part II, on the other hand, analyses the data in relation to similar theoretical propositions, and draws comparisons based on the 
common themes that emerged in both cases that contribute to existing knowledge about these theories.

\section{Ethical considerations}

Given that most of this study was based on human research, ethical considerations were addressed in accordance with the Human Ethics Committee's (H.E.C.) Guidelines and Policy of the Victoria University of Wellington. Approval was sought from the H.E.C. for the project in general, as well as more specifically for the interviews with the key role players. This was granted on the 15 December 2008 by the H.E.C.

In light of General Principle 2.1 a. of the H.E.C. Guidelines, all participants were requested to provide voluntary, informed consent for participating in the study. This consent was sought using a consent form (attached as Appendix 3). Data collected during the in-depth interviews was recorded for accuracy and information. Once the interview material was woven into the thesis, the research participants were asked to cross-check their information for correctness of content and appropriateness within the context of the discussion. Any necessary adjustments were made following their feedback. Of the total twenty-one participants, four did not respond to the researcher's request for comments on the use of their interview material in the thesis.

As described in Section 4.1.e. of the H.E.C. Policy, participants were given the option to remain anonymous unless they gave signed consent to be named. It was considered preferable for the key role players to be identified given their significant contributions to the process of youth justice transformation.

There was no deception in the way the data was collected from the participants, and data collection complied with the Privacy Act (1993) as required by the General Principles 2.1.b. in the H.E.C Guidelines. Information was securely stored by the researcher.

Given that the participants came from broad range of backgrounds, the researcher ensured that appropriate measures were taken to be sensitive to their backgrounds. This included cultural sensitivities as well as a general awareness of their roles and responsibilities in relation to the topic. This was in accordance with General Principal 2.1.e. of the H.E.C. Guidelines.

\section{Overcoming challenges}

The main challenge in conducting the research was collecting data from various locations from two countries. This was both in terms of collecting largely archived documents as 
secondary data sources, as well as conducting face-to-face interviews with the participants. The researcher was based in Wellington, New Zealand during the data collection period, but travelled to Auckland and Christchurch to meet with participants in person. Two trips of approximately four weeks were made to South Africa during this period which enabled most of the South African interviews to be conducted in person including in Pretoria, Johannesburg and Cape Town. One participant from South Africa was interviewed in Australia where she was residing at the time and one was interviewed via Skype as he was not available to meet in person during the trips to South Africa.

Another challenge was the unpredictable dynamic nature of the processes of youth justice transformation in both countries at the time of conducting the research. While there had been little change to New Zealand's youth justice system in over twenty years, it was subject to some significant amendments during the research period. On the other hand, an advantage was that the CYPF Act of 1989 reached its twenty year anniversary during the research period; a milestone celebrated as testimony that it had stood the test of time. This milestone seemed to remind some of New Zealand's participants of its history and their involvement in it; they recounted their stories with detailed enthusiasm, despite the time lapse since their involvement. South Africa was still going through its process of child justice transformation during the research period. At the onset of the research, the Child Justice Bill had reached a stalemate in Parliament and there was no certainty as to whether it would progress. During the course of the research, there were significant advances, with the Bill being redrafted, heard, passed and implemented as law in South Africa. These advances could not have been anticipated by the researcher in the beginning. Nevertheless, they added richness to the exploration and analysis and bolstered the chosen dimensions for the comparative case study. It was important to ensure that the research was sufficiently anchored by the key research questions whereby the dynamic contexts could add value to the analysis rather than serve as a distraction.

It is further noted that the purposive selection of participants and the use of the phenomenological research approach means that this study represents a unique point of view in relation to the research questions. Therefore, this thesis primarily explores one side of the story, which has been largely constructed from the chosen participants' recall and insights into the research questions being explored - this includes descriptions of the challenges and opposition faced by the participants interviewed. It is, however, acknowledged that there are other points of view and dimensions to this story that have not been explored in this thesis. 
These include the perspective or challenges faced by those who opposed the changes being advanced and implemented in both countries. Also not explored in this thesis are the experiences of grass-roots community activists whose voices influenced the participants, the experience of practitioners responsible for implementing the changes, or the experiences of individuals who have been involved in the youth justice systems being described. These additional dimensions would certainly add new insight into the story. However, they were outside of the scope of this research, which was essentially concerned with the experiences of individuals in places of influence who converted the voices of the community activists into youth justice systems that aimed to respond to their needs, and who successfully drove this process in both countries. 
PART I:

$\underline{\text { The Cases }}$ 


\section{Chapter 3}

\section{The history of race relations in New Zealand and South Africa that influenced changes to their youth justice systems}

From a distance, New Zealand and South Africa's socio-political histories and contexts might seem too different to be able to draw any relevant parallels. Internationally, New Zealand, with a population of just over four million, is renowned for its commitment to the integration of European and indigenous populations, for being the first country to give women the vote and for its all-round clean, green image. With a population of approximately eleven times that of New Zealand, South Africa, on the other hand, received international notoriety for human rights abuses and oppression of indigenous populations by European settlers, epitomised by its undemocratic apartheid regime. While the transition to the 'new South Africa' certainly brought about a spirit of democracy and unity, after the honeymoon period faded, the legacy of the past proved difficult to overcome. South Africa has since become well-known for its high levels of violent crime, wide gaps between rich and poor and one of the world's worst HIV and AIDS epidemics - all of which created challenges for thousands of children.

However, when unpacking the sequence of events that led up to the significant law changes to youth justice in both countries it becomes evident that multiple comparisons can be drawn in the process of shaping their youth justice systems.

This chapter describes the impact of the history of race relations in New Zealand and South Africa, with a particular emphasis on the effects on indigenous families and their ability to care for their children. It explains the similar effects of colonisation which systematically eroded traditional ways of life and how indigenous groups resisted western influences and tried to reclaim their rights to self-determination in both countries.

\section{New Zealand}

The issue of race relations between European settlers (Pākeha) and indigenous Māori inhabitants of New Zealand (Tangata Whenua ${ }^{9}$ ) started gaining momentum during the nineteenth century. Europeans arriving in New Zealand introduced foreign trade, and many

\footnotetext{
${ }^{9}$ Māori term meaning 'people of the land' or indigenous people.
} 
Māori quickly adapted to this new system, enjoying the benefits of weapons and luxury items. Europeans in turn relied on Māori to provide manual labour and access to land (Orange, 1987:7). While a symbiotic relationship had started to form between some Māori and their European visitors, this was also a confusing time for indigenous Māori, who faced a range of colonial pressures that tugged at their sacred land, cultural beliefs and possessions and disturbed their traditional way of life. Rifts started to emerge as New Zealand became recognised as a useful trade route bringing more European settlers and traders to the islands (Orange, 1987).

\section{The Treaty of Waitangi}

British settlers soon started gaining in numbers and influence. By 1840, when encouraging Māori Iwi ${ }^{10}$ chiefs to sign the Treaty of Waitangi, British authorities took advantage of Māori vulnerability by emphasising the benefits of British protection (Orange, 1987:33). From the British perspective, the Treaty's objective was for Māori to relinquish sovereignty to the Crown on the understanding that Māori would retain self-determination (tinorangatiratanga) in relation to the management of matters of key significance to them such as land, forests, fisheries and taonga ${ }^{11}$ (Orange, 1987:1). Consedine (2001:87) notes that William Hobson, who had been appointed by the British Crown to negotiate the Treaty with Māori Iwi chiefs, was advised that "he was to obtain sovereignty, but only if Māori were willing to cede it; and he was to obtain land but on the condition that Māori retained enough for their own purposes and would not be disadvantaged". Iwi chiefs were of the understanding that the Treaty would ensure that they retained power over their land. They believed that signing the Treaty signalled their acknowledgement that foreigners had come to settle amongst them and that the Crown would be responsible for managing unruly behaviour displayed by some of their people (Orange, 1987:33; Mikaere, 2008).

Different interpretations of the English and the Māori versions of the Treaty, particularly of the meaning of the term 'sovereignty', resulted in Māori effectively being misled by the British. ${ }^{12}$ Cleave (1989) describes the different understandings as being based on a fundamentally different world view between the British and Māori, whereby the British relied on the language of "western law" and Māori had a more "anthropomorphic and mythological

\footnotetext{
${ }^{10}$ Māori term meaning tribe

${ }^{11}$ Treasures as defined by Māori tied to customs grounded in lore and ancestry.

${ }^{12}$ Mikaere (2008) argues that the differences in interpretation and meaning between these two documents is so extreme that they cannot be considered versions of the same document.
} 
interpretation" (Cleave, 1989:46-47). Cleave thus explains that for the British, the notion of sovereignty was implicitly aligned to "Empire, Queen, the Church of England and God", whereas to Māori, the notion of sovereignty is linked to "the charismatic quality $\left(\operatorname{mana}^{13}\right)$ of the chief (rangatira)" (Cleave, 1989:47).

In the years following the signing of the Treaty, the British claimed vast amounts of land in order to better accommodate their settlement. At the same time, the European settlers brought diseases for which Māori had no cure. The increasing influx of European settlers coupled with the high number of Māori deaths from battles and imported diseases eventually tipped the population balance, so that Māori became the minority (Walker, 1990:80). ${ }^{14} \mathrm{New}$ generations of European immigrants, further removed from the spirit of the Treaty, (Orange, 1987:3) systematically ignored the principles of the Treaty, taking over land and fisheries with little consideration for their sacred value to Māori. In this process, they increasingly destabilised Māori customs including cultural beliefs and language.

The degradation of the Māori language, particularly through native schools set up in the latter part of the nineteenth century where children would be punished for speaking Māori, disturbed young Māori. Walker (1990:80) points out that "the damaging aspect of this practice lay not in corporal punishment per se, but in the psychological effect on an individual's sense of identity and personal worth".

\section{A policy of assimilation}

Urbanisation of Māori increased significantly following World War II. Their survival on rural land was becoming untenable and they required employment, which the government was able to provide, largely in various factories (Durie, 1989:288). To consolidate the geographical and social merging of Māori and British the Labour government introduced their policy of assimilation in the 1930s, which compelled Māori to adopt European culture, ideas and practices (Mulgan, 1989:1). This government policy was thought to have benevolent intentions: it provided Māori with welfare benefits aimed at improving the lives of all New Zealanders and incorporated Māori people into what they considered their superior European culture and lifestyle. The New Zealand government considered this gesture morally superior to their colonial counterparts whose policies were based on principles of oppression and

\footnotetext{
${ }^{13}$ Mana is roughly translated as 'honour' or 'prestige', acquired through connection with one's heritage and genealogy, as well as through a character that reflects Māori values and culture.

${ }^{14}$ Consedine (2001:99) notes that "the Māori population, possibly as high as 200,000 at the beginning of the $\left(19^{\text {th }}\right)$ century was by its end a mere 45,000 while the European population had climbed to 770,000 ".
} 
separation rather than on principles of inclusion aimed at creating one nation comprising a mixture of races who shared the same culture, values and beliefs (Vasil, 1990:97).

However, assimilation essentially meant depriving Māori of their own rich cultural heritage, including their language. In addition to this, urban migration resulted in the erosion of important Māori family and social structures fundamental to their cultural survival and social unity (Durie, 1989). This was exacerbated, for example, by British adoption policies introduced in the early twentieth century. Rather than seeking alternative care within the extended family structure, as was customary in Māori child rearing practices, children were adopted by families that had no link to the original family. For Māori, this was a foreign way of dealing with children (Consedine, 2001).

The rise in poverty among Māori in the rural areas and an increase in their urbanisation around the war years led to an escalation in the state's concerns about Māori behaviour. Many Māori children behaved in ways which led to them being labelled juvenile delinquents. Some welfare officers suggested this behaviour was due to their struggle to adapt to the European way of life combined with the impoverished conditions many were living in (Dalley, 1998).

\section{Māori resistance}

Māori had been trying to retain tinorangatiratanga from the time of the signing of the Treaty. In the earlier years this included a number of battles against the invasion of the settlers, as well as pacifist Māori movements aimed at holding on to their beliefs and customs (Orange 1989; Walker, 1990). Te Whiti O Rangomai, for example, emerged as a notable Māori leader in the late nineteenth century. According to Keenan (2005), Te Whiti was believed to possess spiritual powers handed down through his ancestors. He encouraged his people to stage a non-violent resistance to settlers taking their land. After seeing wars fought and lost by Māori, he devised an alternative strategy to develop a community that stayed true to Māori heritage and way of life, resisting the confiscation of the land or introduction of any European influence or infrastructure. This peaceful action was met with arrests without trial and eventually a hostile takeover by the settlers (Walker, 1990).

In the years of increased urbanisation, many young Māori who moved to urban centres felt confused, isolated and lonely. They united to maintain a sense of solidarity and familiarity, and engaged in cultural practices in an attempt to hold on to their heritage and identity (Grace 
et al, 2001). After many years of trying to be heard through various formal and informal channels, and as local customs eroded, Māori became increasingly vocal and rebellious in claiming their rights. In the late 1960s, two political newsletters were formed to raise Māori awareness about how they were being disadvantaged. The newsletters resulted in the formation of 'Nga Tamatoa' in 1970 "whose members advanced the consciousness raising process amongst Māori society on issues pertaining to the erosion of Māori rights in Aotearoa/New Zealand" (Ka'ai, 2004:184). This movement was aimed at monitoring and supporting Māori in western environments, such as in criminal courts, while also ensuring that they maintained cultural awareness. Visits to rural areas were arranged so that urban Māori could spend time on marae and with elders, where they learned their language and absorbed cultural knowledge and identity (Ka'ai, 2004). This group of activists also advocated for Māori rights through petitions calling for the survival of Te Reo Māori ${ }^{15}$ as well as staging protests at annual Waitangi Day celebrations (Walker, 1989). At the time, Māori demands were still little understood by Pākeha society, who thought Māori should be satisfied with the notion of one united people of New Zealand under the Crown. The activists who were being portrayed as dangerous 'radicals' by the media, were "considered heroes and heroines by Māori of a younger generation who were inspired by their passion for the rights of Indigenous people of Aotearoa" (Ka'ai, 2004:184). This revolutionary period was coined the 'Māori renaissance': it sought to advance Māori culture as an integral part of children's upbringing and families' lifestyle, as well as being incorporated into the national identity (Walker, 1990).

Activism during the 1970s and 1980s led to important outcomes for Māori, including the Waitangi Tribunals, which were first established in 1975 under the Treaty of Waitangi Act and later amended in 1985. These tribunals were set up to hear Māori grievances as a result of breaches of the Treaty since its inception and to make recommendations to Crown for addressing the breaches (Sorrenson, 1989:160). As political protests by Māori increased during the 1970s and 1980s, Pākeha were gaining consciousness around the plight of Māori in New Zealand. They started becoming active in trying to gather evidence of inherent discrimination against Māori and publically demonstrating their disapproval.

The South African Rugby tour in 1981 brought the issue of race relations to a head in New Zealand due to the international condemnation of South Africa's apartheid laws at the time.

${ }^{15}$ Māori language 
Many New Zealanders rejected the idea of a sports team representing South Africa's racist government being invited to play in their country. According to Consedine (2001:110), "Many Māori and Pākeha agreed on the issue and came together to support the protests in a watershed moment for New Zealand, which again exposed the raw nerve of racism underpinning our society and challenged New Zealanders to think more deeply about their own country".

The 1980s became a period when most of New Zealand society started to become aware of Māori grievances, which many Pākeha previously had chosen to either ignore or undermine. The Waitangi Tribunals, marches, Waitangi Day and other protests for the rights of Māori as well as reports on institutional racism from non-governmental organisations forced the government to acknowledge that there was a problem and that perceptions of social harmony between Māori and Pākeha were misleading (Vasil, 1989; Walker, 1990). Quince (2007:14) points out that the expanding rift caused by these protests resulted in an increase in police preparing "in riot gear, armed with long batons in preparation for Māori protesters, who were often arrested and detained".

\section{Uncovering the experience of Mäori in the child welfare system}

As social activity around race relations was increasing in New Zealand, investigations into the abuses of children in the child welfare system were also taking place. Jacky Renouf ${ }^{16}$ spoke of her memories of children's institutions gained while working as a community development worker in 1981. She explained that part of her university training as a social worker required her to go to some of the residential homes, which she referred to as "punishment centres essentially". Renouf recalled being "appalled" by the state of the children there:

Some of the things I can think particularly as they related to young women were just atrocious. I mean young girls from twelve years old who went into children's homes were checked for venereal and sexually transmitted diseases. It was gross, and I am not sure it was always done by a physician. And they were also humiliated. They made them wear rompers. They were pretty ugly garments. That was for the first month or so that they were in residential care. As a young feminist at the time, I was totally appalled. But

\footnotetext{
${ }^{16}$ Interview with Jacky Renouf, dated 30 March 2010
} 
there were groups that were active, particularly in Auckland ... they were starting to make noise about residential care and the recognition that incarceration was setting them off on a course of crime, and that they went from a children's home into borstal into prison. It wasn 't working, and while it was under a welfare banner, it certainly wasn't welfare or wellbeing anyway.

Robert Ludbrook, a former member of the Auckland Committee on Racism and Discrimination (ACORD), discussed how the committee was called on to look into complaints of abuse in the children and young persons' welfare homes in the 1980's. He explained that this led to the Human Rights Commission conducting an investigation resulting in a report which was released in 1982. This report emerged after sustained campaigning by Māori. Ludbrook recalled:

It was the first major inquiry that they (the Human Rights Commission) had done. It took a couple of years as they were understaffed, and they wrote a report. It was toned down because everybody was nervous, but in the end it came to the conclusion under the United Nations Covenant of Civil and Political Rights these children were being subjected to inhumane treatment and punishment. ${ }^{17}$

Mike Doolan, who had been appointed head of residential services by the Department of Social Welfare around the same time, and who had also been working as a senior social worker in these institutions for some years previously, commended ACORD's research. ${ }^{18}$ In particular, he applauded the focus on the racism affecting children in institutions and ACORD's ability to raise this as a human rights issue through the Human Rights Commission:

It produced data that showed the disproportionate treatment meted out to Mãori youngsters because they were Māori. In other words, in controlling for other factors they were able to establish that Māori young people were four to six times more likely to be arrested, more likely to go to court and more likely to suffer a custodial disposition for the same offence than had they been white. So that was pretty important stuff. Parallel to that, they

\footnotetext{
${ }^{17}$ Interview with Robert Ludbrook 20 March 2010.

${ }^{18}$ Interview with Mike Doolan dated 7 April 2010.
} 
developed this advocacy role particularly for Māori youth, and they took the Department of Social Welfare on about their treatment of young people in the residences in Auckland. The Human Rights Commission decided to have hearings about these complaints.

Doolan noted that he had started to observe the difficulties for Māori in the system early on in his career, as he had been one of the few Pākeha appointed as a Māori Welfare officer by the Māori Affairs Department in the 1960's. These research findings reported first by ACORD and then reinforced by the Human Rights Commission, validated concerns he had held for some time without knowing how to address them. ${ }^{19}$

The Human Rights Commission's report on racism and the poor conditions in the Department of Social Welfare residences in 1982 initially resulted in a number of policy changes by the Department of Social Welfare aimed at improving the running of the institutions. ${ }^{20}$ This included the setting up of Maatua Whangai, which was developed as a collaborative effort between the Departments of Māori Affairs, Social Development and Justice aimed at putting measures in place to:

a) Prevent the 'flow' of Màori people into government institutions; and

b) Take Màori people out of these institutions and place them into the care of the Whanau ${ }^{21}$-Iwi groups.

(Maatua Whangai Policy Objectives, 1983)

Nevertheless, the 'Women Against Racism Action Group' (WARAG), a group of Pākeha women concerned about racism in New Zealand, produced a damning report in 1985 (WARAG, 1985) on the extent of inherent institutional racism in the Department of Social Welfare in New Zealand. Doolan described this report as another "curve ball" for the Director General of Social Welfare, John Grant, who concluded that the issue needed to be extensively explored. ${ }^{22}$

\footnotetext{
${ }^{19}$ Interview with Mike Doolan dated 7 April 2010.

${ }^{20}$ Ibid

${ }^{21}$ According to Judge Brown (1992:98), "Whānau is the smallest social unit within the biological family. The term covers the two preceding generations of grandparents and parents, the generation of the person concerned and the two succeeding generations of children and grandchildren".

${ }^{22}$ Interview with Mike Doolan dated 7 April 2010.
} 


\section{Setting up the Ministerial Advisory Committee on a Mäori Perspective for the Department} of Social Welfare

With civil society reports revealing concerns about institutional racism and the emerging conditions in residential homes, Ann Hercus, the New Zealand Minister of Social Welfare at the time, called for a more in-depth exploration of these matters. Following discussions with John Grant, the Director of Social Welfare, she set up the Ministerial Advisory Committee on a Māori Perspective for the Department of Social Welfare. ${ }^{23}$

This Advisory Committee was tasked with consulting Māori around the country to understand their experience of the Department of Social Welfare with a view to better addressing their needs. The terms of reference for the committee called for special consideration to be given to the following aspects:

c) Identification of Māori client needs

d) Establishing effective contact with tribal groups

e) Appropriate direction of programmes to meet community and client needs

f) Possibility for decentralisation and devolution

g) Appropriate requirements and mechanisms for accountability

h) How attitudinal change can most effectively be achieved

i) Appropriate public relations for the exercise

(Ministerial Advisory Committee, 1986:5)

Donna Hall, a young female Māori lawyer, was appointed to the Committee as its youngest member. She described her memory of being part of the Committee as follows: ${ }^{24}$

The government commissioned this small committee which was headed by John Rangihau, who remains somebody who is held in very high esteem amongst Māori ...They sought to get a mixture of elders and I was brought in because of my age... We travelled the entire country...The issues that Māori people raised were much broader than youth justice issues. There was a whole range of concerns about the way the Department (of Social Welfare) was dealing with Màori. A particular criticism was that the Department basically told Mãori what is good for us, and what we heard

\footnotetext{
${ }^{23}$ Interview with Mike Doolan dated 7 April 2010.

${ }^{24}$ Interview with Donna Hall dated 20 March 2010.
} 
was: 'How 'bout you just let us do this ourselves? We can do this better ourselves!'

Taking that particular principle thrust and applying it to children who were getting into trouble, what we heard from Māori communities everywhere and what I know from my own experience (I come from a Māori community), is that there is a sense of helplessness when it comes to care of our children because all the decisions were being made for us and about us and to us by people who often couldn't pronounce our names ...You had Päkeha policemen picking on Māori, getting sworn at, and then (the police officer) would get punched and kicked and get called all sorts of rude and horrible names by the kids. This would make the officers really cross. They would take it out on the kids - not by beating them, but by prosecuting them: 'I'll fix you, you little prick!' They would make the decision on what [the children] would be charged with. If the children were just giving the police officer a hard time, you can be sure they would get the book thrown at them. We spotted that, and knew it was not correct. There needed to be a book. That was one of the first principles that we could see needed to happen.

The second principle was that there didn't seem to be any place in the whole of the criminal justice system dealing with our children where Māori families could have a say about their kids. These were Māori families' children. The children belonged to families that had a right to have a say. But they were separate from their kids, and there needed to be a better way to do it.

Doolan explained that in his position he also had the opportunity to travel with the Ministerial Advisory Committee to listen to the voices of Māori and get direct insight into their grievances:

That was a fascinating experience. That's when what I knew in my head began to actually hit the heart. Màori people were starting to say that what you are doing might be with the best will in the world, and you might have good intentions, but it is harming us in huge ways. They were able to demonstrate the huge alienation of children from their families and from 
their hapū and iwi. The loss of children to Päkeha carers, and the pain and the hurt that goes with that were stories that we heard time and again on the $\operatorname{marae}^{25}{ }^{26}$

The report from the Ministerial Advisory Committee on a Māori Perspective for the Department of Social Welfare was named Puao-Te-Ata-Tu meaning 'Daybreak'. It signalled the hope that a new approach to working with Māori children would result from documenting the voices of Māori families and communities. In summarising their findings and overall views in light of their investigations, the Committee noted:

We comment on the institutional racism reflected in this Department and indeed in society itself. We have identified a number of problem areas in policy formation, service delivery, communication and racial imbalances in the staffing appointment, promotion and training practices. We are in no doubt that changes are essential and need to be made urgently...At the heart of the issue is a profound misunderstanding and ignorance of the place of the child in Māori society and to its relationship with whānau, hap $\bar{u}^{27}$ and iwi structures (Ministerial Advisory Committee, 1986:7).

In exploring the circumstances of Māori in New Zealand's criminal justice system, Quince (2007:3) posits that "colonisation has, in fact, directly shaped the socioeconomic position of Māori to such an extent that offending produced by poverty and other related demographics, and the sentences that such offending attracts are connected to ethnic identity... what is happening to Māori within the justice system...is happening to them because they are Māori”. This is not to say that Māori were the only social group represented in the welfare and justice systems. However, as Doolan pointed out, the ACORD report in the early 1980's found that Māori were at least six times more likely to be represented than Pākeha, despite Māori being the minority, which supports Quince's claim.

\footnotetext{
${ }^{25}$ A Marae is the traditional Māori sacred meeting place used for community gatherings. Strict protocols are followed when convening gatherings at Marae. Protocols may vary depending on the local people belonging to the Marae. Visitors to the Marae are required to respect and follow these protocols in order to be accepted by the local people allowing for open discussion and, where necessary, resolution of matters.

${ }^{26}$ Interview with Mike Doolan dated 7 April 2010

${ }^{27}$ Māori term for sub-tribe.
} 


\section{South Africa}

South Africa's colonial history shared a number of similarities with that of New Zealand, particularly once British rule was introduced. British colonists quickly took control of the wealth and the land and drew up boundaries that would prevent indigenous people from entering and residing in areas the British had moved into. By 1910, the South Africa Act prevented blacks from sitting on parliament. Three years later, the Native Land Act dictated where blacks could own land. Therefore, early colonialism in South Africa's destabilized indigenous ways of life and liberty and set the foundation for apartheid rule to be introduced (Beck, 2000).

\section{Apartheid}

The apartheid system galvanised the issues around race relations in South Africa. It entrenched racial separation through legislation imposed by the white National government in 1948. The timing of this policy was somewhat ironic on the international stage given that it was the year of the adoption of the Declaration of Human Rights. South Africa's apartheid policy undermined key elements of the Declaration, particularly with regard to racial discrimination. International opinion was deliberately ignored by the National government when creating their domestic policy, which was primarily driven by the intention to best serve white South Africans (especially the Afrikaners). Prime Minister D.F Malan and his Minister of External Affairs were concerned that signing the Declaration of Human Rights could result in international interference in domestic affairs and undermine the politics of racial segregation being established under their leadership (Shearar, 2011: 46, 63).

\section{A policy of separation}

The apartheid policies of separation that followed had a dramatic effect on the African, indigenous populations of South Africa on several levels. These included further demarcating specific areas where non-whites ${ }^{28}$ could live and move, reducing opportunities for work and education, limiting interracial association and marriage and requiring non-whites to carry pass books. ${ }^{29}$ The white population would use black people for cheap labour, often exposing

\footnotetext{
${ }^{28}$ South Africa comprises of a number of social groups. During the apartheid years, European settlers were classified as 'whites' and social groups who did not have European features were classified as 'non-whites'. These groups included Natives (or indigenous Africans), Coloureds and Indians. Categorising social groups in this way was part of the government's strategy to impose the policies of separation.

${ }^{29}$ An identification book which 'non-whites' could be asked to produce at any time by police. Non-whites were subject to arrest if books were not produced on demand. The United Nations Centre Against Apartheid (1985)
} 
them to precarious situations such underground mining, and for infrastructure work or as domestic workers for white families. These policies severely affected indigenous social unity and culture. Many indigenous African communities were used to living in rural settings within extended family structures, collectively responsible for raising children. The separatist land and labour laws, which had already started to be implemented before the introduction of the apartheid system, dislocated traditional family systems. This often resulted in parents spending lengthy periods of time away from their children with little communication. Extended families were split up, and the new living conditions also put pressure on their ability to care for children in the customary way (Atmore, 1992:3; Sachs, 1994:3; Skelton, 2005:307).

\section{African resistance}

Many black children witnessed adults in their communities being degraded, oppressed and intimidated by the apartheid government structures. As a result, they also saw these adults becoming angrier with the apartheid laws and taking increasing action to resist them. This started the struggle against apartheid, which took on various forms including protest marches and defiance campaigns. In March 1960, a pass book protest outside a police station resulted in the police opening fire and killing 69 protesters, including women and children. This event became known as the Sharpeville Massacre: it shocked the world and added fuel to the international anti-apartheid movement. Banned political opposition groups including the PanAfricanist Congress (PAC) and the African National Congress (ANC) started to form militant wings after non-violent methods of resisting apartheid had failed. These opposition strategies continued to operate underground, both inside and outside the country.

On 16 June, 1976, black South African children became a symbol of the struggle when they protested against the use of Afrikaans as a means of instruction in schools (International Defence and Aid Fund, 1988:19). Again, this non-violent demonstration which was primarily staged by black school children resulted in police opening fire leaving 176 people killed and many more injured. This incident epitomised state abuse against children and marked the beginning of more systematic and organised opposition to apartheid by young black people in

described the influx control laws governing the pass book as follows: "The intention behind the influx control laws is that all Africans must live in their respective 'self-governing homelands'. Therefore, unless an individual qualifies to live in a white area he requires permission to work in 'white' South Africa as a migrant contract labourer and may not bring his family to live with him. Furthermore, in terms of government homeland policy, once a 'homeland becomes 'independent' its citizens automatically lose their South African citizenship whether they live in a homeland or not". 
South Africa. In turn, this resulted in increased threats and human rights violations against them by the state, and an augmentation in the movement against the South African government by a number of governments and anti-apartheid groups that had formed around the world. ${ }^{30}$

Turbulent times ensued. International pressure as well as increasing violent opposition, which involved a number of black children, began to debilitate the apartheid government. As a result, the government heightened its resistance to the anti-apartheid movement through the use of force, increasing the powers of the police and even the army. The 1980s saw some of the worst abuses against children in the apartheid era as they became more vigilant and violent in their opposition (Dowdall, 1994:77). ${ }^{31}$ Dowdall (1994:79) describes this phenomenon as an "intricately interwoven blend of 'political' and 'criminal", which saw increased opportunities for the South African police to arrest, detain and torture black children.

\section{State retaliation against children involved in the struggle}

While the targeting of youth by the state had steadily increased, particularly since the 1976 youth uprising, it reached a crescendo during the state of emergency imposed by the apartheid government initially in July 1985 and then more forcefully in June 1986. This period allowed government forces to arrest individuals without a warrant and to detain anyone they suspected of activity against the apartheid government. These actions happened largely under a veil of secrecy and little information about police and military activity was released to the public. Arrests and treatment of children under this regime overrode existing policies that were in place to provide some protection to children, including the Child Care Act of 1982 which was aimed at preventing children from being ill-treated or neglected. A number of voluntary monitoring groups tried to gather as much information as possible. A report from a group called the Detainees Parents Support Committee (DPSC) released in November 1986 described their findings on violence against children perpetrated by the state as follows:

At first hearing these kinds of reports it would seem that the police and other security forces are involved in random acts of violence. However, when these reports are all taken together what is most clear is the way in

\footnotetext{
${ }^{30} 16$ June is now commemorated annually around the continent as the Day of the African Child.

${ }^{31}$ Terry Dowdall was the Director of the University of Cape Town's Child Guidance Clinic.
} 
which such incidents add up to form a systematic campaign of terror

against children (International Defence and Aid Fund, 1988:19).

According to monitoring reports by DPSC, it was calculated that at the height of the state of emergency, $40 \%$ of detainees were under the age of 18 years, and that over a five month period approximately 8,800 children were detained at a rate of about 250 children per week (Detainees Parent's Support Committee, 1986:10).

A group of doctors set up to treat detainees following their release during the state of emergency described the physical and emotional impact of the experience on children as similar to experiences of torture victims, including "renal failure, brain haemorrhage and broken limbs" as well as "post-traumatic stress syndrome" (International Defence and Aid Fund, 1988:21-22). According to the International Defence and Aid Fund (1988:22) "the fierceness and brutality of the regime's attacks on children is a reflection of the determination of children to organise and play a part in changing the society in which they lived". ${ }^{32}$ Cairns (1996) noted that during South Africa's state of emergency, what made this situation unusual compared to most others where children were exposed to political violence around the world, was that South Africa's children and youth were direct active participants and leaders in the movement. Some research conducted on the youth involved in this movement found that being ideologically connected to the political cause helped to buffer the impact of the violence and oppression meted out against them and their families and communities by the state. Lazarus (in Cairns, 1996: 55) believed that this direct involvement helped children and youth gain a sense of mastery over the situation, which would otherwise have left them impotent and victimised. Bawa (date unknown:183) notes that the South African state of emergency in particular left many children with the following options: "escape into selfdestructive anomie, anaesthetising themselves through substance abuse, or withdrawing into a world of private pain and alienation...Or they can oppose that which attempts to make them partner in their own oppression. They can fight back - both psychologically and physically, often by violent means". Dawes, who interviewed youth detained in custody during the state of emergency found that their experience of detention strengthened their commitment to the cause (Dawes, 1990:24).

\footnotetext{
${ }^{32}$ Because of the secrecy surrounding the 'state of emergency' as well as other acts of violence and abuse of power perpetuated by the state against children, particularly after 1986, it is difficult to get correct figures accurately reflecting impacts on children. According to the International Defence and Aid Fund (1988:13) the official figures of police action against children, recorded between 1984-1986, noted that approximately 300 children were killed, 11,000 detained without trial, 18,000 arrested on charges arising out of protest and 173,000 held awaiting trial in police cells.
} 


\section{Civil society starts to take notice}

As a result of the number of children being detained during the state of emergency, reports on the conditions under which they were being detained, the secrecy surrounding their detention and the uncertainty of the exact numbers, the Black $\operatorname{Sash}^{33}$ joined forces with concerned civil society organisations and individuals to launch an awareness campaign about the problem of children in prison. This campaign which was initiated on 13 November 1986 was called 'Free the Children'. Its position was that no children should be in prison awaiting trial and that alternative measures had to be found. Their first action was to send Christmas cards to Prime Minister P.W. Botha in 1986 urging him to 'free the children'. On 29 January 1987, campaign supporters held a vigil at St. George's cathedral in Cape Town after which the 'Free the Children Alliance' was formed, uniting the concerned parties to continue to gather information about children in prison and to lobby for their release. ${ }^{34}$

The then Minister of Law and Order, Adriaan Vlok, responded in writing to the Alliance that their campaign was "grossly exaggerating" the numbers and countered the campaign position by making the point that the "ANC and other radicals do not hesitate to misuse children of any age, in their efforts to make South Africa ungovernable" (Vlok, 1987). ${ }^{35}$ This letter also noted "I will not detain a child unless I consider it absolutely necessary". ${ }^{36}$ The Black Sash took exception to this comment stating "there seem to be so many cases of arbitrary detention where the children have been detained for long periods and are not even politically involved". ${ }^{37}$ They decided to collect as many names of juvenile prisoners and reasons for their being detained to submit to the Minister of Law and Order. ${ }^{38}$ Mary Burton, the National President of the Black Sash, had already made it clear in one of her initial 'Free the Children' campaign letters dated 29 January 1987 that detention of any children was unacceptable. She wrote:

\footnotetext{
${ }^{33}$ The Black Sash was established in 1955. It was a resistance organisation initially made up of white South African women who protested against a number of apartheid policies including the pass laws.

${ }^{34}$ Free the Children Alliance letter to interested agencies following their initial meeting held on 16 February 1987 (undated-from the Black Sash archives held at the Manuscripts and Archives at the University of Cape Town).

${ }^{35}$ Letter from Adriaan Vlok, Minister of Law and Order to Isobel Douglas Jones from the Black Sash dated 23 January 1987 in response to a "Free the Children" advertisement which appeared in the Weekend Post on 20 December 1986. The advertisement called for the release of children from prison, noting that "according to the Detainees' Parents Support Committee, more than 8,000 children have been detained in five months" (Black Sash archives).

${ }^{36}$ Ibid

${ }^{37}$ Letter between Black Sash members, Jenny de Tolly and Isobel Douglas-Jone dated 1 March 1987 following Adriaan Vlok's response dated 23 January 1987 (Black Sash archives).

${ }^{38}$ Ibid
} 
What we do know is that it is wrong for even one child to be held in prison or in detention. We know that this conviction is shared by millions of our fellow citizens. We commit ourselves to working together with all concerned people and organisations to bring this present shameful situation to an end. ${ }^{39}$

The Alliance continued their lobbying. In April 1988 Alliance members attended a conference held at the Wits Great Hall in Johannesburg named The Children's Commission Apartheid on Trial where individuals could discuss their experience of detention or of assisting people in detention. ${ }^{40}$ The Alliance helped to inform the public on the issue of children in detention and was successful in getting a number of children released from custody, particularly those under the age of fifteen. ${ }^{41}$ However, it was unable to achieve changes to the conditions of children in detention. This reflected the vulnerability of youth at risk of becoming involved in criminal behaviour in general in South Africa.

Don Pinnock who eventually became a senior lecturer at the Institute of Criminology at the University of Cape Town in the mid-1990s explained that he first started taking an interest in young people at risk when he lived in Long Street in the centre of Cape Town in the early 1980's. He recalled:

There were lots of kids down below involved in gang activities. I got to know them and suddenly realised they had been flushed out of District Six. ${ }^{42}$ I got really interested in how they ended up on the streets...I had this concept that society was avenging itself on kids through no fault of their own mainly through group areas removals. They ended up on the streets and were trying to re-establish a family connection, which ended up being gangs...there were no ancillary adults to correct, control or look after those kids, so they looked after themselves. ${ }^{43}$

\footnotetext{
${ }^{39}$ Campaign letter written by Mary Burton, the National President of the Black Sash (Black Sash archives)

${ }^{40}$ Report on the Children's Commission - Apartheid on Trial (1988)

41 "Their only right a name: Children under the state of emergency in South Africa" - a report prepared by Janet McCurdie on behalf of the Free the Children Alliance for the International Congress on Working for Children's Rights held in Finland from 16-18 June 1989 (Black Sash archives)

${ }^{42}$ District Six was a multi-cultural district of Cape Town, South Africa which in 1966 was declared a white's only area. This resulted in the forced removal of approximately 60,000 residents to the outlying areas of the Cape Flats. The forced removal of residents from District Six had a serious impact on the community fabric.

${ }^{43}$ Interview with Don Pinnock dated 2 March 2011.
} 


\section{Civil society starts to consider solutions for children in conflict with the law}

In 1987 the Swedish Save the Children International NGO (then known as Rädda Barden) held a summit in Zimbabwe entitled 'Children, Repression and the Law' followed by a publication by UNICEF entitled Children on the frontline: The impact of apartheid, destabilisation and warfare on children in Southern and South Africa. Both this summit and publication helped to generate support for children in South Africa (Parliament of South Africa, 2011:11). In the 1990s Brigitte Mabandla became the co-founder of the National Committee on the Rights of the Child (NCRC). This committee was initially formed outside of South Africa in Botswana in 1990. Mabandla had supported children's interests from early in her career as the youth coordinator at the Institute for Race Relations in Durban in the mid1970s. She later played a critical role in ensuring that children's rights remained a government priority during the drafting of South Africa's constitution. She also became the first coordinator for research on children's rights at the Community Law Centre at the University of the Western Cape.

Within the NGO sector, a number of key role players and leaders concerned with child justice started to emerge. In 1991, Rosemary Shapiro-Liu was working as a senior social worker for the Cape Town Branch of the National Institute for Crime Prevention and Reintegration of Offenders (NICRO) ${ }^{44}$ when she visited Pollsmoor Prison in Cape Town. There she met with children awaiting trial and witnessed the conditions they were being kept in, which she described as follows:

I went into prison to have a look at what was going on, and came across the maximum security prison at Pollsmoor - 35 young people in one room awaiting trial. The one window was really high up. They had to stand on each other's shoulders to look out that window, and if they could see out they saw the maximum security prisoners training in the yard below. Kids were in there 23 hours a day. Many of them were there for suspicion of having stolen bread or a bicycle, mixed with kids who were on suspicion of rape and murder. I was utterly appalled! $!^{45}$

\footnotetext{
${ }^{44}$ NICRO was first established in South Africa in 1910 as the Prisoners Aid Association. It is a national nongovernmental organisation which provides re-integrative support to offenders in custody prior to release and in the community.

${ }^{45}$ Interview with Rosemary Shapiro-Liu dated 11 February 2011.
} 
Distressed by what she had seen, Shapiro-Liu asked her supervisor why NICRO was not doing anything to keep these children out of prison. As a result, her supervisor suggested that she initiate a programme for this purpose. Shapiro-Liu stated "I don't even remember how I got involved in the beginning, but it became an issue for me, so I was on it. It was an intention! "46 Once Shapiro-Liu became committed to finding solutions to the problem of youth in custody, she started meeting other individuals who shared her concern. Among them was Ann Skelton, who had been working as a prosecutor for South African children during the apartheid years from 1986. Skelton recalled:
My first experience really was of being on the other side prosecuting children, and I saw what was happening to them and how there wasn't a special system for them. There were no diversion programmes; whipping was still used as a sentence. It was a really tough regime. And so I discovered pretty early on that I am not very prosecution oriented, I am more defence oriented, because I kept on wanting to assist the people I was supposed to be prosecuting. ${ }^{47}$

With her instinct to assist, Skelton joined an NGO called Lawyers for Human Rights, ${ }^{48}$ which she described as her "spiritual home". ${ }^{49}$ This decision gave her the flexibility to set up projects in areas of specific interest. Skelton explained that her experience working with children in conflict with the law inspired her to address their needs. She consequently set up a project in Pietermaritzburg, KwaZulu-Natal on South Africa's east coast between 1991 and 1992. The purpose of this project was to: "interview all the children who appeared in court before they appeared in the Magistrate's Court, get lawyers to act for them pro bono, and to make arguments to avoid the use of whipping" which she described as "very basic stuff in those days" ${ }^{50}$ Skelton tried to convince prosecutors to put children through a life-skills programme as a humane alternative to a sentence of whipping.

While concerned groups made headway in drawing attention to the problem of children in detention in South Africa, their efforts were limited while the apartheid laws prevailed. In order for efforts to gain momentum, there had to be a shift in the political climate that would

\footnotetext{
46 Ibid

${ }^{47}$ Interview with Dr Ann Skelton dated 28 September 2009.

${ }^{48}$ 'Lawyers for Human Rights' was established in 1979 in South Africa to address human rights abuses under apartheid.

${ }^{49}$ Interview with Dr Ann Skelton dated 28 September 2009.

${ }^{50}$ Interview with Dr Ann Skelton dated 28 September 2009.
} 
provide enough of a platform for these children's rights to be considered and taken seriously. The need to address the dire circumstances for children in trouble with the law in South Africa was identified by President Mandela in his opening speech as the first president elected by universal suffrage in 1994 . He noted:

The Government will, as a matter of urgency, attend to the tragic and complex question of children in detention and prison. The basic principle from which we will proceed from now onwards is that we must rescue the children of the nation and ensure that the system of criminal justice must be the very last resort.

By singling out the needs of children in the criminal justice system in this speech, President Mandela highlighted the particular vulnerability of this group of children, bearing in mind that all non-white children had been neglected and abused in many ways during the apartheid years.

\section{Conclusion}

In order to appreciate the significance of the changes to New Zealand's and South Africa's youth justice systems, it is important to understand the backgrounds in both countries that created the need for change. This chapter has highlighted key similarities in the histories of race relations between New Zealand and South Africa. The socio-economic circumstances that prevailed over generations meant that many families were unsettled and children often lost consistent contact with their parents. Many children and young people started to either actively oppose government policies, or struggled to find a sense of identity and belonging. As a result of their behaviour, children and young people in both countries ended up in state custody, where their parents were unable to either make decisions about what should happen to them or to take care of them. The theories discussed in the next chapter will consider how these social histories affected indigenous children and young people's normal development in both countries. 


\title{
Chapter 4
}

\section{The impact of adversity on children and youth development}

\author{
In the developmental process, the child forms a picture or draws a map of \\ the world and his or her place in it. If a child's map of the world depicts \\ people and places as hostile, and the child as an insignificant speck \\ relegated to one small corner, we must expect troubled development of one \\ sort or another: a life of suspicion, low self-esteem, self-denigration and \\ perhaps violence and rage.
}

(Garbarino et al, 1992)

This chapter discusses theories that explain the impact of negative social, political and economic circumstances on children's pro-social development. It starts with the premise that children and young people's social, emotional and moral development is largely determined by cues from their social environment (Tasler, 1972: 140). The ecological theory of human development provides a backdrop for demonstrating how human development is primarily a product of dynamic social experiences. It demonstrates how damaged or dysfunctional relationships, particularly as the result of social injustice or exclusion, can contribute to offending behaviour by children and young people. These social theories on the causes of offending behaviour also highlight the negative effects of New Zealand and South Africa's histories of social injustice and exclusion on children and young people's development.

\section{The ecological approach to human development}

James Garbarino, a prominent social psychologist, was concerned with the importance of the social environment on the survival and development of children and their families. In his view, understanding this context would help to develop the guiding principles for social policy that would assist children and families to thrive rather than struggle (Garbarino, 1982). In his exploration, Garbarino begins by asking the question:

Where is the beginning of this chain of relationships that binds together child, parents, aunts, uncles, grandparents, friends, neighbours, communities and professional helpers? It would be easy to cast aside the interconnections and pretend that there is 
just the developing child, or just the family as a social unit, or just the community power structure, or just the human delivering social services. It would be easy, but we believe it would not be enough. Rather we seek to capture the whole tangled mass of relationships connecting child, family and social environment (Garbarino, 1982:1).

In trying to understand these complex social influences, Garbarino was drawn to Uri Bronfenbrenner's research into what was termed 'The ecology of human development' (Bronfenbrenner, 1979). Bronfenbrenner was interested in how children's relationships and social influences affect their development and social functioning. He divided these influences into various systems which a child interacts with either directly or indirectly. These systems were called the 'microsystem', 'mesosystem', 'exosystem' and 'macrosystem' (Bronfenbrenner, 1979). Bronfenbrenner viewed human development as a process based on how an individual interacts with the different systems and the individual's experience and perception of these systems (Bronfenbrenner, 1979:22).

According to Bronfenbrenner, the micosystem represents the smallest 'unit' of interactions, which takes place between the individual and a particular setting. He states that "the factors of activity, role and interpersonal relation constitute the elements or building blocks, of the microsystem" (Bronfenbrenner, 1979:22). This could be a child's interactions in the home or a child's interactions in the school setting for example. Garbarino considers that having a variety of microsystems to interact with enhances an individual's development whereby "social risk and opportunity can exist side by side" (Garbarino, 1982:36).

The mesosystem is the more complex set of interactions between various microsystems relevant to an individual, such as between the individual, home and school for example. It reflects how human development is the product of a compounded series of dynamic relationships and experiences. Taking this further, the theory introduces the influence of what Bronfenbrenner terms the 'exosystem' (Bronfenbrenner, 1979). Bronfenbrenner posited that in some cases individuals can be influenced by the impact of situations experienced by people close to them without having to be exposed to those situations themselves. For example, if a child's father has been to prison, that child will be affected by the father's experience of prison via their interactions following the father's release, even if the child has no first-hand experience of prison. This phenomenon was noticed in research conducted by Skinner and Swartz (in Dawes, 1989:19) on the effects of political violence on children in South Africa. Common research findings among a group of young children whose parents were detained in 
custody were "sleep disorders and nightmares, fears of security forces and regressive behaviour in the form of increased dependency on adults".

The macrosystem refers mostly to the broader social context in which the micro-, meso- and exo- systems operate. Bronfenbrenner described the macrosystem as providing a "system blue print", which, within a given context, will create commonalities in the interactions within and between the other systems and relevant settings (Bronfenbrenner, 1979:26). Bronfenbrenner points out that while there may be similarities in micro- and meso- systems within one social group (such as in the way children interact with their families for example), these could be quite different to another social group: "The systems blueprints differ for various socioeconomic, ethnic, religious and other sub cultural groups, reflecting contrasting belief systems and lifestyles, which in turn help to perpetuate the ecological environments specific to each group" (Bronfenbrenner, 1979:26). Macrosystems therefore help to distinguish one social group from another due to the particular nuances and patterns of behaviour within each social group. In providing a 'system blue print', macrosystems help to shape certain norms of behaviour for the social groups.

Using the cases in this research as examples, it is notable that New Zealand's policy of assimilation and South Africa's apartheid system altered the indigenous population's system blueprints. As a result it confused social connections and belongingness for the indigenous populations in both countries, who struggled to adapt to the new, colonial macrosystems. Disruption to indigenous functioning ultimately affected the forming of normal social bonds, and children's ability to form healthy attachments with family members or consistent caring adults. This was both as a result of families being fractured through social policies and urbanisation, as well as children and young people being institutionalised by the state - either in welfare residences, where they suffered abuse or neglect (in New Zealand) or prisons where they were tortured (in South Africa).

\section{Developing healthy attachment}

Social psychologist John Bowlby explored the importance of attachment between children and their parents following his experience observing the negative effects of institutionalisation on children. He found that children with a loving and reliable relationship with their parents were less likely to display deviant patterns of behaviour. While parents are considered an important source of comfort and social support, another social psychologist who researched attachment in children, David Farrington, found that children will develop 
healthy attachments depending on the consistency of the relationship, not necessarily with a parent, but at least with a trusting and reliable caregiver. Farrington believed that "the development of affectionless characters and delinquency may have more to do with the lack of a continuous, unbroken, loving relationship with one person than with the loss of the mother specifically" (Farrington 1996:9). Werner (in Garbarino et al 1992) found similar results when researching children's resilience in communities affected by violence. He noted that a number of other caretakers "can play an enabling role" which could include siblings (albeit preferably in a "supplemental rather than substitutive" capacity) (Werner and Smith in Garbarino et al 1992:107). Persistent exposure to inconsistent, unreliable relationships can affect a child's healthy development and sense of self-worth. This in turn can inhibit their moral development and understanding of social norms. Garbarino further noted that parenting ideally should enable reciprocity. For example, this could be about the process of parents setting boundaries followed by the child challenging those boundaries, and then both parties negotiating a compromise. Garbarino believed that this approach is more likely to result in healthy, confident development and relationships than if a parent is either too authoritarian or too lax: "Neither does justice to the child's developmental needs because both undermine the social richness of the family microsystem" (1979:37).

According to Thornberry, society relies on certain mechanisms for developing an understanding and appreciation of social norms and values to guide their day-to-day activities. He referred to these mechanisms as "bonds to conventional society represented by three broad constructs: attachment to parents, commitment to school and belief in conventional values" (Thornberry 1996:211). These constructs are similar to the elements Hirshi (in Bartol et al, 1989) identified as part of his social control theory: "Attachment to parents, teachers and peers, commitment to conventional lines of activity, such as educational and occupational aspirations, involvement in conventional activity and belief about the legitimacy and morality of social norms and laws".

The experiences of many indigenous children and young people in both New Zealand and South Africa did not enable them to either form healthy attachments or to have relationships that would support development through reciprocity. The lives of many children and young people from oppressed social groups in both countries were characterised by transience, separation from families and abuse by the state. The majority of these children's development was stunted by the power dynamics where state authorities would dominate and control them, providing little opportunity for negotiation. Children and young people who were not 
institutionalised by the state were often exposed to the negative experiences of state control over the significant adults in their families which undermined their ability to best care for their children. Their homes were characterised by low socio-economic status where parents or care givers struggled to find stable employment, and where relationships often became violent, fuelled by drugs and alcohol and criminality (Farrington in Hawkins, 1996:69). Children brought up in these environments are likely to feel neglected, unwanted and abused, while at the same time learning that these behaviours are normal. These experiences in New Zealand and South Africa shaped children and young people's view of themselves as unworthy citizens and of the world as a place to fear or fight. As a result, they resisted forming significant bonds to conventional society.

\section{Broader social influences}

The Chicago School of Sociology conducted the first research into the social impact of urbanisation in the 1920's. Early on, this research discovered that "extremes in poverty, illness and crime were found disproportionately in particular parts of the city" (Bartol and Bartol, 1989: 81). Geographical mapping of disenfranchised communities helps to identify disparities between classes and social status; often referred to as the 'haves' and the 'have nots' (Bartol and Bartol, 1989:276) reflecting a Marxist formulation of criminal behaviour being born out of class inequalities. Overlaying an ecological lens suggests that chronic disadvantage, poverty and criminality endemic to certain communities or neighbourhoods can start to shape their macrosystems and perpetuate the negative cycle for children and young people. This phenomenon became increasingly evident over years of social imbalance experienced by the indigenous populations in New Zealand and South Africa. Cunneen and White (2002) found that where social norms were defined by poverty, lack of opportunity and deviance, criminal behaviour can be perceived as one of the few opportunities for success.

Shaw and McKay developed the notion of strain theory to provide an explanation for deviant behaviour through the relationship between individuals and their attempts to measure up to society's expectations and definitions of success (Bartol and Bartol, 1989). Strain theory posits that strain exists where aspirations are unachievable. Therefore, the greater the distance between an individual or a community's reality and their ability to meet their hopes and aspirations, the greater the strain experienced (Bartol and Bartol, 1989). As a result, this strain can draw individuals towards criminal behaviour to achieve their goals. Strain theory is generally considered more pronounced in communities that struggle to achieve conventional 
norms and expectations. This is exaggerated in societies driven by consumerist market economies to define achievement and success, where communities characterised by low socio-economic income and poor education are inherently disadvantaged. Coward and Ohlin (1961) found that prolific criminals are often exalted by youth in disadvantaged communities. These criminal role models are generally accessible to youth from their communities and neighbourhoods. They will often involve impressionable young people in criminal activity, giving them a sense of importance and worth which they might struggle to achieve in more privileged environments.

Barry (2006:33) observed that while strain can affect communities at large "powerlessness is perhaps the most acutely felt by young people in transition and offending is an escape from such disempowerment". As a result they resort to their "individual agency" to overcome their powerlessness (Barry, 2006:33). This may include deviant or criminal methods, particularly where conventional or legitimate means are out of reach. However, this may result in these children being labelled by society causing them to become further alienated. Tannenbaum's labelling theory, proposed in 1938, referred to the negative labels given to individuals whose behaviour appears not to match conventional norms. Negative labels can undermine a child's self-image and identity, thereby living out the behaviours that match the label (Bartol and Bartol, 1989). As a result of this experience children tend to gravitate to others with similar labels, and form their own groups where they can gain a sense of belonging and social inclusion (Sampson and Laub in Thornberry, 2006:139).

Fitting into conventional society can be particularly difficult for children and young people from disadvantaged communities. Conger and Simmons (1996) explain that children from disadvantaged environments naturally struggle in more conventional settings. As a result, they will seek out peer groups whose members are similar to them, where they can feel accepted. These peer groups then form their own set of values and norms which can reinforce deviant behaviour. During their longitudinal investigations into the causes of juvenile offending, Farrington and $\mathrm{West}^{51}$ found that children from deprived and criminal upbringings who tried to live according to conventional norms tended to cope poorly. According to Moffit (in Thornberry 2006:34), "research is beginning to suggest that abstaining from delinquency is not necessarily a sign of good adolescent adjustment" and that contextual norms and

\footnotetext{
${ }^{51}$ Farrington and West conducted a longitudinal study on 411 boys in the UK to determine the factors that contributed to offending behaviour, including causes of onset, persistence or desistence. This research is considered one of the most influential longitudinal studies into offending behaviour.
} 
rewards are better indicators of an individual's perceived success. Shaw and McKay (in Bartol and Bartol, 1989) referred to this as an "alternate mode of socialisation into a deviant subculture". However, the forming of deviant sub-groups that reflect social constructs and labels can reinforce debilitating social perceptions, often boosted by dominant social labelling structures such as popular media and political campaigning (Muncie, 1999:40), generally geared towards creating a state of "moral panic" (Muncie, 1999:122). Cunneen and White (2002:88-89) believe that labelling increases the likelihood of targeting certain individuals deemed deviant or delinquent for the purposes of "surveillance and intervention", thereby enhancing the "processes of criminalization". They believe that "viewing young people as a law and order threat has serious consequences for our ability to develop socially just responses for young people and our ability to respect young people's human rights" (Cunneen and White, 2002:95). Conventional court processes have also been condemned for their role in labelling and perpetuating criminal behaviour. Sampson and Laub (in Thornberry 2006:139) quote Garfinkle's (1956) reference to the criminal justice system as a 'status degradation ceremony'. As a result, society's reaction to offending by youth can be more damaging than the behaviour itself (in Bartol and Bartol, 1989).

While labelling may have a negative impact on children and youths' self-image, and lead to behaviour which might reinforce the label, social learning theory explains that all behaviour can be attributed to the perceived rewards it generates, thereby reinforcing it. This equation for deviant behaviour was supported by prominent social psychologists who promoted social learning theory, such as B.F. Skinner (Bartol and Bartol, 1989). The thinking is that if youth choose to repeat certain behavioural patterns, they must prefer the consequences of that behaviour. Rotter (in Bartol and Bartol: 1989:157) noted that the preferred consequences could include "status, power, affection, material goods or living conditions". Social learning theory posits that finding rewards from deviant, unconventional or illegitimate sources can result in a sense of satisfaction which helps young people cope with difficult circumstances. According to Conger and Simpson (in Thornberry, 2006:89), “aversive conditions result in these individuals being attracted to and spending much of their time with anti-social youth... These anti-social youngsters will tend to reinforce and amplify each other's antisocial tendencies". For young people this often includes thrill seeking behaviour such as reckless driving or property crime, or finding a means of escape such as through substance abuse, (which while illegitimate can also result in further serious offending behaviour such as violent or sexual offending). It is suggested that in these settings a new set of norms and 
values are created which support the group's ethos and sense of reward. These subcultures can sometimes manifest as gangs.

During a visit to the youth awaiting trial section of Pollsmoor Prison in Cape Town in 2003, when the researcher informally questioned a group of youth about their life aspirations, most responded that they wanted to become drug merchants for various gangs. ${ }^{52}$ The majority of these youth were from an area of Cape Town called the Cape Flats which has become notorious for its high rate of gang related drug and violent crime, including organised crime (Kinnes, 2000). A study carried out by New Zealand's Ministry of Social Development on youth gang members in Counties Manukau noted similar findings. This research noted that: "What can be determined is that young people in economically deprived areas in Counties Manukau may view adult gang members as role models and see adult gang membership as a status to which to aspire" (New Zealand Ministry of Social Development, 2008). This report described how during the economic downturn in the 1970's, Counties Manukau became a hub for blue-collar workers mostly consisting of Māori and Pacific Islanders who had been moving to the urban areas since the 1950's. It notes the "ingredients of social dislocation, combined with the economic depression and marginalisation in Counties Manukau created a perfect environment for gang activity which began to grow as the 1970s progressed (Gilbert and Newbold in New Zealand Ministry of Social Development, 2008).

Don Pinnock, a South African criminologist, was interested in the appeal of gangs for young people. He hypothesised that this was linked to a deeper adolescent need tied up in rites of passage into adulthood (Pinnock, 1997). After observing and interacting with a number of young people in gangs on the streets of Cape Town, he questioned whether gang involvement was merely a symptom of their circumstances, or whether they were somewhat inadvertently seeking out a developmental need. In order to explain this, Pinnock referred to a number of indigenous adolescent rituals around the world, which, rather than suppressing "youthful wildness...capture its intensity in rituals which teach and inspire while protecting social life from adolescent excesses" (Pinnock, 1997:6). Pinnock argued that young people's inherent calling for a rite of passage between childhood and adulthood becomes distorted and potentially dangerous in dysfunctional, dislocated and disenfranchised communities. In these situations, the natural guidance from adults assisting young people's adolescent transition into adulthood is disrupted, largely leaving energetic, isolated and rejected youth to figure out

\footnotetext{
${ }^{52}$ Visit to Pollsmore Prison in Cape Town as part of the University of Cape Town's Probation and Correctional Practice Honours curriculum in 2003.
} 
how to manage the transition. In contexts which offer little adult support and oversight, young people seek out respect from their peers in the form of gangs who share their sense of rejection. They compensate for a lack of socially sanctioned rites of passage through acts of violence or disregard for social conventions and law enforcers. Pinnock (1997:8) explains, "Gangs are all about this warrior energy in search of respect and rites of transgression".

\section{Offending behaviour as part of normal development}

Some criminologists contend that deviant behaviour is a relatively normal part of adolescent development (Elliott and Menard in Hawkins, 1996). This is usually explained as being due to adolescents' natural gravitation away from parents towards peer groups to guide their social development when they are leaving the protection of childhood and taking steps towards becoming independent adults. Barry (2006) explains this shift in terms of 'social capital', which depends on the importance youth place on their relationships. Low levels of attachment with parents can cause children and young people to undervalue this relationship from early on. As a result, they may seek social capital elsewhere, such as from a caring adult or from selected peer groups (Barry, 2006:48, 51). The social capital theory suggests that investing in peer relationships over relationships with parents during adolescence is common (Barry 2006:1).

Most criminologists who study juvenile delinquency agree that deviance is generally limited to a period when it is normal to test boundaries as part of the process of establishing one's identity, autonomy and independence. It is therefore viewed as being part of the normal developmental process. This was a common finding in Farrington's longitudinal studies (Farrington in Hawkins, 1996). Hence, while reinforcement of deviant behaviour may increase during adolescence, it is likely to dissipate when legitimate means for status, wealth, power and belonging become more tangible, and an individual's adult identity has formed. As such it is rare that children and youth commit very serious offences, or that their offending is persistent and enduring. In the 1960's, David Matza proposed what he referred to as 'drift theory,' which observes that juvenile delinquency is not a static state, but rather that adolescents tend to drift between delinquent behaviour and conventional norms depending on the perceived advantages at the time. He viewed this as part of the social learning process, including the development of conscience and a sense of guilt from harming others (Bartol and Bartol, 1989). In referring to Matza's theory, Barry (2006:33) notes that this experience "manifests itself in the transition phase of youth when young people fall between the two 
schools of relative protection as a child and interdependence as an adult" (Moffit in Thornberry, 2006).

While anti-social behaviour is largely limited to a period of adolescence and then tends to tail off considerably from early adulthood, Farrington (1996) and Moffit (2006) have recognised that there exists a group of life-course persistent offenders whose offending is likely to have had an early onset, often due to negative life circumstances. Moffit (2006:17) noted that the causes of anti-social behaviour between life-course persistent offenders and individuals whose criminal activity is limited and time-bound are quite distinct and should therefore be studied separately in order to best understand and address the causes of their offending behaviour. In his research into gang association as an adolescent 'rite of passage' Pinnock (1997) suggests that life-persistent offending can originate when young people fail to distinguish between reality and fantasy. He explains that there is the risk they start to believe that their gang 'ritual' behaviour is like acting in a movie. When the boundaries between reality and fantasy start to blur inextricably and youth relish in their gang status, it becomes harder to conform to social norms and conventions, potentially resulting in a life of crime. Therefore Pinnock believes there is a need to create alternative rites of passage in societies where these traditional processes have eroded. The alternative rites should allow young people to use their energy while supporting them through a safe transition into adulthood.

\section{Conclusion}

This chapter has looked at various social theories related to children's development from infancy to adolescence which explain factors contributing to offending behaviour. A common theme in many of these theories is the impact of social disadvantage and strain, a lack of healthy attachments and marginalisation on children and young people's development. Chapter 3 considered how indigenous children and young people's upbringing and worldview in both New Zealand and South Africa would have been influenced by their negative life experiences. Given that a number of these children were ending up in the criminal justice system as a result of their social identity and circumstances, changes to youth justice policies that would address their needs and support their pro-social reintegration into the community were imperative. In order for this approach to youth justice to succeed, the overarching social contexts which drove the negative outcomes for these children, young people and their families in both countries also needed to change in order to accommodate this approach. 


\section{Chapter 5}

\section{Youth justice transformation in New Zealand and South Africa}

Chapter 4 looked at some of the social theories which explained the impact of negative social circumstances on children and young people's development in New Zealand and South Africa. When trying to cope with their circumstances, indigenous children and young people in both countries were labelled, further marginalised or further institutionalised, and these perpetual negative outcomes contributed to patterns of intergenerational criminality over time. Faced with clear evidence of a downward spiral of outcomes for these populations, officials in New Zealand and South Africa believed that transforming their youth justice systems could be one way to help break the cycle in both countries. The vision for this transformation focused on a restorative, rights-based approach to youth justice, which would include and empower participants, address harm and support pro-social reintegration in the community.

This chapter provides a socio-historical account of the processes of youth justice transformation in New Zealand and South Africa, constructed from the interviews with the research participants, and supported by documents and archival records. It reveals the significance of the shifting social contexts in both countries that started to address social injustices of the past. It looks at the importance of the connections and networks that formed between key role players both nationally and between the two countries, the factors that helped shape policy design and the struggles each country faced to officially establishes a new framework for their youth justice systems. Comparisons are drawn between the cases, highlighting the similarities and differences between the processes of transforming their youth justice systems. These comparisons included how key individuals were affected by their exposure to the negative conditions experienced by children and young people in state institutions, the influence of community groups (particularly indigenous groups) who spoke out against human rights abuses and systemic racism that was affecting their ability to adequately raise their children, the determination of key role players to work through opposing positions to advance their proposals and the advantages of political interest and will in supporting the proposed youth justice changes in both countries. 


\section{New Zealand}

This section looks at the process of youth justice transformation in New Zealand resulting in the youth justice provisions in the Children, Young Persons and their Families Act of 1989. It starts by identifying some of New Zealand's responses to children in conflict with the law and reveals how Māori social uprising in the 1980s ultimately influenced the changes to New Zealand's youth justice system to address the negative impact of previous social welfare and youth justice policies.

\section{Previous legal provisions for children in conflict with the law in New Zealand}

The first legislative framework for dealing with children in conflict with the law in New Zealand was the Neglected and Criminal Children's Act 1867. It aimed at providing for "the care and custody of neglected and criminal children" (Phillip, 1945:4). This period saw a number of children being placed in industrial schools for between one to seven years. The positioning of welfare policies under the Department of Education during this time led to an increase in institutionalisation to have better control over children. This was considered to be in the interest of all New Zealanders (Dalley, 1998). However, by 1916, the Department of Education realised that it was unable to cope with the large numbers in its institutions resulting in neglect and abuse of children residing there. As a result the Department sought to deinstitutionalise children, preferring the options of fostering and community oversight. A probation system for supervising delinquent children in the community had already been set up by 1913 (Phillips, 1945).

Changes to child welfare policy resulted in the Children's Welfare Act 1925. The Department of Education created the Child Welfare Branch to oversee matters pertaining to this legislation. As with many emerging policies, this welfare approach was essentially imported from the United Kingdom and the United States and was designed to address children's needs within a European context. Offending behaviour by children and youth was primarily dealt with through general child welfare provisions. A Children's Court was established to deal with children in need of care and protection as well as children in conflict with the law. Industrial schools were abandoned, as a greater emphasis was placed on community-based care. This included boarding arrangements with foster families, with oversight and interventions provided by state welfare officers. Children coming to the attention of the welfare system were mainly given 'court ordered supervision', which would enable welfare 
officers to work closely with families and children to deal with their needs or the factors contributing to their delinquent behaviour (Dalley, 1998).

The Children's Welfare Act 1925 was eventually replaced by the Children and Young Person's Act 1974 after close on fifty years. While this Act still utilised a welfare approach to deal with children in conflict with the law, it did introduce some new features. One of those features was to distinguish between 'children' and 'young persons', with 'children' being below the age of 14 and 'young persons' being between the ages of 14 to 17 years of age. The other was the establishment of the Children's Boards (Watt, 2003:8). These Boards were made up of a police officer, a social worker and a representative of the Ministry of Māori and Island Affairs to respond to offending by children and youth (Morris, 2004). They were tasked with increasing the opportunities and options for diversion for young offenders as well as to enable increased community representation when considering outcomes for children and young people. Possible responses to children in conflict with the law included police warnings or referring children for counselling. More serious matters would generally be referred back to social welfare to be dealt with in the Children and Young Persons' Court (Morris, 2004), which replaced the previous Children's Courts (Watt, 2003:8). Like their predecessors, these courts also dealt with both children in need of care and protection as well as children in conflict with the law "and used the same welfare-based dispositions for all juveniles coming to official notice" (Watt, 2003: 9).

\section{Exposing concerns around child abuse and neglect in New Zealand}

Concerns around the abuse and neglect of children in their family homes (including sexual abuse) had been increasing since the 1970's after Henry Kempe's research on the matter had started causing an international stir (Leventhal, 1997). ${ }^{53}$ It took New Zealanders some time to come to terms with this phenomenon given their pride in New Zealand being a safe place to raise children. ${ }^{54}$ In 1979, New Zealand set up the National Advisory Committee for the Prevention of Child Abuse and Neglect (NACPAN) following a symposium to raise awareness about child abuse held in Dunedin that year (Dalley, 1998: 342). This symposium

\footnotetext{
${ }^{53}$ Interview with Dr Ian Hassall dated 2 February 2011

${ }^{54}$ Ibid
} 
and the establishment of NACPAN corresponded with the International Year of the Child. NACPAN was initially chaired by the then head of Plunket, ${ }^{55}$ David Geddis.

Ian Hassall was appointed to NACPAN to represent the New Zealand Medical Association. Hassall was a paediatrician who became aware of the effects of child abuse through his clinical work with children and families when he helped establish the Child Abuse Prevention Society (Parent Help). He stated this Society had "a much wider support base than just the health care medical area" noting:

There were health care workers and ordinary citizens who wanted to know what this new phenomenon of child abuse was all about. We set up a help line for parents who were worried that they might do harm to their children. $^{56}$

This gave Hassall insight not only into the effects of abuse, but also the needs of parents wishing to avoid abusing their children. In addition to this work, Hassall had also become involved in the Plunket Society. He noted that he was attracted to Plunket's community-based roots born out of the initiative of a group of concerned mothers committed to providing the best possible care for their children. Hassall's background as a paediatrician focusing on child abuse cases provided important insight into the phenomenon when he joined NACPAN. He advised: "Our job was to see what could be done to deal with this new and frightening phenomenon of abuse and neglect of children around the country". ${ }^{57}$ Pauline Tapp was the lawyer appointed for NACPAN to provide a legal perspective on child protection issues.

NACPAN were interested in promoting the Denver, Colorado model for addressing child care and protection needs. This model sought to establish teams of professionals from the health, welfare, justice and police sectors, primarily responsible for making decisions and intervening in all cases of child abuse and neglect. NACPAN had initially set up two of these professional teams in the early 1980's in Mangere and Otara in South Auckland. ${ }^{58}$

\footnotetext{
${ }^{55}$ Plunket is an organisation started in 1907 by Sir Frederic Truby King in Dunedin, New Zealand, to respond to the needs of mothers and babies suffering from disease and malnutrition. Plunket has since continued to service mothers and babies in New Zealand to support their wellbeing in their early years.

${ }^{56}$ Interview with Dr Ian Hassall dated 2 February 2011

${ }^{57}$ Ibid

${ }^{58}$ Ibid
} 


\section{Identifying the shortcomings in New Zealand's child welfare system}

While the broad issue of child abuse and neglect had gained in profile during the late 1970s, as noted in Chapter 3, the 1980s saw growing discontent with existing welfare provisions both for children in need of care and protection and children in conflict with the law. Reports from children's rights activists on cases of neglect and abuse in child welfare institutions had already been causing alarm. ${ }^{59}$ At the same time, police were not convinced that diversion measures imposed by the Children's Boards were proving to be effective. As a result, they started to bypass this system, making arrests for prosecution which resulted in an increase in children and young people appearing before the courts (Watt, 2003:9). This undermined the intention of the 1974 Act to minimise the stigmatising effects of the criminal justice system on children and young people. According to a report by Renouf et al (1989:1):

$$
\begin{aligned}
& \text { Officials were concerned about the ineffectiveness or unsuitability of many } \\
& \text { parts of the legislation. They had witnessed the deficiencies in the operation } \\
& \text { of the Children's Boards, the net-widening effects of its approaches to } \\
& \text { juvenile offending, the reliance on custodial care of offenders, the lack of } \\
& \text { resourcing Children's Courts and the lack offocus on 'preventive' } \\
& \text { activities. }
\end{aligned}
$$

There was a growing political will to review the Children and Young Persons Act 1974. According to Renouf et al (1989:1), there had already been amendments to the Children and Young Persons Act of 1974 in 1977, 1982 and 1983. While the first two amendments were primarily interested in enhancing children's rights in the youth justice provisions, the 1983 amendments essentially sought a number of improvements related to care and protection. The 1983 proposed amendments sought better involvement of families in child protection matters (Renouf et al, 1989:1). The establishment of the NACPAN had a strong influence on the direction of the 1983 amendments, resulting in the drafting of a Child Protection Bill. This Bill placed significant emphasis on the role of professionals in child protection matters. It was criticised for its narrow scope and limited consultation, which prevented it from progressing in Parliament (Renouf et al, 1989:3).

In 1984, Minister Hercus put together a working party to provide "an urgent and comprehensive review of the legislation in this area of the law" (Department of Social

\footnotetext{
${ }^{59}$ The WARAG and ACORD reports
} 
Welfare, 1984: iii). The working party continued to promote the professional approach to child protection recommended by NACPAN in the Child Protection Bill. This 'Review of Children and Young Persons Legislation' which influenced the content and design of the new Children and Young Person's Bill of 1984 still called for the establishment of multidisciplinary teams of professionals to respond to matters pertaining to "investigation, assessing and planning of child protection". This approach received strong backing from Geddis in particular, who had concerns about some families' ability to look after their children (Renouf et al, 1989:2).

The professional focus of the 'Denver model' was soon rejected by a number of social work practitioners who favoured a more community-based approach to caring for children (Renouf et. al.1989:3; Cheyne et al, 2000:195). The virtually simultaneous exposure of the systemic racism in the child welfare system by the Māori Advisory Committee in the Puao-Te-Ata-Tu report exacerbated this tension and agitated the policy debate.

\section{Two emerging schools of thought to address child welfare needs}

Puao-Te-Ata-Tu made thirteen recommendations to the Department of Social Welfare as a result of their findings, aimed at addressing every level of institutional racism as voiced by the community. According to the 'Te Whanau o Waiperera Report' (1998:128): "Puao-TeAta-Tu went much further than encouraging a bicultural perspective within the Department. The goal in terms of the report is a proper engagement between the Crown and Māori, sharing power and control over resources, a mutual accountability where the relationship harnesses the potential of all Māori in the most effective manner". However, at the time the Māori Advisory Committee's findings were being released, the 'Review of the Children and

Young Persons Legislation' was being considered separately. It was soon recognised that despite the similar timings of the two reviews, the legislative review had been prepared without any reference to the findings in Puao-Te-Ata-Tu.

Combining the findings from the two policy advisory groups into a single review might have provided a more comprehensive and holistic overview and approach to addressing the breadth of problems with the Department of Social Welfare at the time. However, not only were they developed separately, but they also originated from opposing interest groups and perspectives. The 'Review of the Children and Young Persons Legis lation' relied heavily on 
professional mechanisms for dealing which children, ${ }^{6061} 62$ and Puao-Te-Ata-Tu called for much higher levels of community engagement in responding to children and young people's needs. ${ }^{63}$

Doolan recalled his concerns when attending the meetings with the Māori Advisory Committee: "We had looming over us the fact that we already had a Bill in the house that was really a continuation of that paternalistic state driven model". 64 This became even more problematic once Māori realised what was happening: "Suddenly we had Māori people saying, 'they're giving us a voice, but on the other hand, they're already telling us that they know what they're going to do'. So there was huge uproar about this". ${ }^{65}$

Gabrielle Maxwell, who was working as a social psychologist based at Otago University at the time the Children and Young Persons Bill was in the House in 1986, recalled attending conferences which would be interrupted by Māori wanting to protest the Bill:

I can remember first being struck (by the strength of feeling on this issue) when I attended a mental health conference up in Auckland for which child and youth mental health was on the agenda. Suddenly groups of Māori who normally didn't attend these conferences in great numbers started turning up to all these sessions, and they basically filibustered. They didn't want to talk about anything else, except their concerns about this Bill, even if the sessions were on a totally different topic. The conference was restructured to make an opportunity for a really in-depth debate...It all came down to this Bill - the Children and Young Persons Bill. ${ }^{66}$

Renouf recalled attending a conference when the debate about the two schools of thought to address child welfare was coming to a head. Geddis had invited the Select Committee to view a presentation on the negative outcomes for children when not dealt with by professionals. Also attending the presentation was a member of parliament from Taupo who was a former medical practitioner. He dismissed several points in the presentation on scientific grounds, thereby providing an ally for the alternative school of thought with the clout of his medical

\footnotetext{
${ }^{60}$ Interview with Jacky Renouf dated 30 March 2010.

${ }^{61}$ Interview with Mike Doolan dated 7 April 2010.

${ }^{62}$ Interview with Gabrielle Maxwell dated 29 March 2010.

${ }^{63}$ Interview with Jacky Renouf dated 30 March 2010.

${ }^{64}$ Interview with Mike Doolan 7 April 2010.

65 Ibid

${ }^{66}$ Interview with Dr Gabrielle Maxwell dated 29 March 2010.
} 
and scientific background. Renouf described this event as "a funny little side-show to what was happening, but quite important", 67

As the new Children and Young Persons Bill reached parliament in November 1986, Minister Hercus also announced her acceptance of all the recommendations in Puao-Te-Ata-Tu, and agreed that a new approach was required to respond to the needs of Māori in the welfare system. ${ }^{68}$ Donna Hall credited John Grant, the then Director General of Social Welfare, with successfully advocating for the implementation of the recommendations from Puao-Te-Ata$T u{ }^{69}$ Grant advised Doolan that the money to implement the recommendations needed had to somehow come from the existing social welfare residences. After holding discussions with a number of Māori representatives and community experts on how this would happen, it was agreed that the Department of Social Welfare would stop taking new children into six of their residences with the view to ultimately closing them down. ${ }^{70}$ While the Māori Advisory Committee's recommendations were given this recognition, there was still no legislative framework to ensure their survival in the social welfare system.

\section{Recasting the draft child welfare legislation}

At the time of the 1987 elections, the Children and Young Persons Bill had stalled in Parliament. Several submissions had been made by a number of interest groups criticising the Children and Young Persons Bill for its mono-cultural perspective and disregard for the recommendations from Puao-Te-Ata-Tu (Department of Social Welfare, 1987:8). John Rangihau, (Chairperson for the Māori Advisory Committee) had addressed the Family Court highlighting the discord among Māori about the Bill. He stated that "alien concepts encapsulated in western legal forms, distanced Māori people from their cultural norms and defeated the maintenance of traditional Māori society".

The 1987 national elections resulted in a new Minister of Social Welfare under the Labour government, Michael Cullen. Minister Cullen had joined the Labour party with "three basic themes to [his] political philosophy". He described these as: "a profound belief in the essential equality of all human beings, a hatred of poverty with its grinding degradation and fundamental unfairness, and that economic and social policy must be guided by the ideals of security and opportunity" (Cullen: 2009). Renouf explained that when the Bill was tabled by

\footnotetext{
${ }^{67}$ Interview with Jacky Renouf dated 30 March 2010.

${ }^{68} \mathrm{Ibid}$

${ }^{69}$ Interview with Donna Hall dated 20 March 2010.

${ }^{70}$ Interview with Mike Doolan dated 7 April 2010.
} 
the Select Committee, two Labour representatives, Annette King and Judy Keall, "were most alarmed at the amount of disquiet there was in the community about the Bill " and immediately advised the new Minister that this needed to be resolved. ${ }^{71}$ Given Minister Cullen's personal set of values and beliefs, he supported the idea of an updated review of the Children and Young Persons Bill which would better address the needs of all New Zealander's, particularly Māori. The polarised positions that had emerged in relation to the most appropriate ways to address matters pertaining to child care and protection and children and young people in conflict with the law led Minister Cullen to seek greater consensus. He wanted the working party to 'recast' the Bill so that it met the following criteria:

- Simpler (administratively and legally)

- Flexible (providing for early intervention)

- Provided resources for services, not for infrastructure

- Culturally appropriate

(Review of the Children and Young Persons Bill', 1987)

Renouf was appointed to lead a new working party to review the existing Children and Young Persons Bill. ${ }^{72}$ She noted that in order to address the "problem areas" in the Bill, it was necessary for the working party to review the entire draft legislation rather than just certain aspects of it. ${ }^{73}$ During this process, the working party conducted a new round of community consultations to inform the content and design of the new legislation. Renouf recalls:

We encouraged the Select Committee to go to hearings on maraes. We took them right up into the back of Tuho ${ }^{74}$ country and we sat them there for about three days, and they had to listen to Māori views. It was very potent. ${ }^{75}$

Armed with a range of ideas, perspectives and influences, the working party needed to come up with a creative solution that would incorporate the complex feedback in a way that

\footnotetext{
${ }^{71}$ Interview with Jacky Renouf dated 30 March 2010.

72 Ibid; Interview with Mike Doolan dated 7 April 2010.

${ }^{73}$ Review of the Children and Young Persons Bill, December 1987.

${ }^{74}$ Tuhoe is one of the few tribes that never signed the Treaty of Waitangi and never agreed to succeed sovereignty to the Crown in New Zealand. They have remained committed to this position and active in promoting their rights to retain their sovereignty.

${ }^{75}$ Interview with Jacky Renouf dated 30 March 2010.
} 
addressed the needs of the various interest groups while still meeting the primary objectives of the task. ${ }^{76}$ Doolan recalled:

\title{
Suddenly we had this 'Eureka!' experience to put our effort and our money into 'process' instead of 'structure'. That's when the family group conference started to emerge. The resources were to be put into the family decision process, not one that we built for ourselves where we would have to appoint people to do it and pay them to do it. ${ }^{77}$
}

This new thinking helped set the foundation for developing the concept of the family group conference (FGC), which would become the cornerstone to New Zealand's approach to care and protection as well as to youth justice. It offered a way to ensure that families were included in decision making that affected them and their children. Hassall, who had been involved in the planning for the multidisciplinary professional approach to address child abuse, and who had worked with Geddis to promote this model, acknowledged that he later saw the benefits of the bicultural community-based approach proposed by the working party. He explained:

\begin{abstract}
In the first place I was keen on the Denver model because I thought it made sense and I had been involved in operating and developing it. But I saw the merit in the family involvement. I very quickly came to the conclusion that it was the right thing to do...I had been involved in Plunket for a long time and believed in the self-help model, believing that people can be entrusted with the management of their own affairs - that they knew best what they were capable of doing. I wasn't starry-eyed or idealised. There are obvious pitfalls with that model as well, but that was my development in relation to that. $^{78}$
\end{abstract}

\section{Incorporating the justice approach}

While the new working party primarily focused on revising care and protection policies, it was also tasked with reviewing the existing provisions for offending by children and young people. The first 'Review of the Children and Young Person's Legislation' (1984:1) had already acknowledged that "benevolently intended official measures employed to rehabilitate

\footnotetext{
${ }^{76}$ Interview with Jacky Renouf dated 30 March 2010.

${ }^{77}$ Interview with Mike Doolan dated 7 April 2010.

${ }^{78}$ Interview with Dr Ian Hassall dated 2 February 2011.
} 
children in difficulty can violate children's civil rights by introducing a level of interference within their lives that is out of proportion to the seriousness of the behaviour that initially prompted the intervention". This insight into the problem of imposing a welfare response to youth in conflict with the law highlighted the lack of legal due process provisions in existing legislation (which Pauline Tapp had identified during the review process), sometimes resulting in inappropriate, overly intrusive consequences for children and young people. Nevertheless, in Doolan's opinion, the 1984 review of the legislation:

....really didn't offer anything radical or new in relation to youth offending. It basically went through the process one would go through if one was an adult defendant - in other words, a pretty orthodox detection, prosecution, adjudication, sentencing sort of an approach. ${ }^{79}$

In the initial stages of the 1987 review of the Children and Young Persons Bill, Doolan was on a study tour to contemplate youth justice practices in Canada, the United States and the United Kingdom. He noticed a growing trend away from the welfare response to dealing with children in conflict with the law. The movement was towards a justice model, which emphasised responses that focused on the offending behaviour specifically and aimed to hold youth to account for their actions. Doolan maintained contact with the working party during the tour in order to update them on his findings and to discuss the implications of what he was discovering in the various external youth justice jurisdictions for New Zealand ${ }^{80}$ As a result of his study tour, Doolan published a report titled 'From Welfare to Justice', highlighting the advantages of using a justice approach to respond to youth in conflict with the law in New Zealand. ${ }^{81}$

Upon his return to New Zealand, Doolan was appointed the National Director of Youth Services and was asked to take the "policy lead for youth justice" for the review. ${ }^{82}$ Doolan's interest in promoting the justice response to youth in conflict with the law helped give shape to a youth justice approach which would replace the existing welfare provisions. Renouf noted:

\footnotetext{
${ }^{79}$ Interview with Mike Doolan dated 7 April 2010.

${ }^{80}$ Interview with Mike Doolan dated 7 April 2010.

81 Ibid

82 Ibid
} 
...the whole notion of kids being accountable and facing the people to whom they had caused the damage and things like that were coming through our working party and being reinforced in other places. ${ }^{83}$

With the shift to the justice model, the working party members wanted to ensure that the new provisions increased opportunities for alternatives to the criminal justice system for youth. According to Doolan:

We had to find a way where diversion would be possible for $100 \%$ of cases, not the $100 \%$ less those who were arrested - and arrest rates were high. Police also used to arrest because it was easier paperwork wise. It was a lot easier to take a matter to court and lay an information than it was to prepare a file that would then go to the youth aid branch of the police who would then manage the diversion. ${ }^{84}$

Therefore, while Doolan was advocating a move away from a welfare response to increase the accountability of young people in relation to their offending, he wanted to ensure that the youth justice response being developed would still emphasise diverting children and young people from formal, traditional justice processes.

\section{The influence of pilot projects in the Family Court}

While Doolan and his working party were figuring out ways to increase alternatives to formal justice processes, a small number of judges in New Zealand were starting to test some of their own ideas to divert children and young people. New Zealand's Family Court was established in the 1981 as a division of the District Court to address legal family matters. During this period, the Family Court was interested in experimenting with approaches that would increase family involvement when considering outcomes for children (Renouf et al, 1989:2). ${ }^{85}$ Judge Carruthers, who was serving as a Family Court Judge, recalled sitting in on Children and Young Persons Court hearings. He was concerned about the number of children appearing in court who he believed should have been diverted, as well as about the processes used for dealing with these youth, particularly in light of the exciting developments taking place in the Family Court. Judge Carruthers explained:

\footnotetext{
${ }^{83}$ Interview with Jacky Renouf dated 30 March 2010.

${ }^{84}$ Interview with Mike Doolan dated 7 April 2010.

${ }^{85}$ Interview with Judge Carruthers dated 17 February 2010.
} 
There was an emphasis under the legislation on diversion, but it wasn't a real emphasis. We had big lists of kids coming in. We were seeing many kids, including kids who had no business coming to court - good kids, done something stupid that kids do, very sorry about it, good family support, with no need for the courts to be involved at all. Sometimes we were expected to be the 'tellers off' - 'you go and see the judge, you get a really big telling off, and boy it serves you right!' It was all nonsense in a way, but it was how it had been for years and years... We put kids in the custody of the Director General of Social Welfare for repeat offending - the old 'moro bar kids' not escalating offending, similar offending, but they were quite often thumbing their nose at authorities, or just going through usual teenage things.

I used to sit and watch this parade, and worry about it because we had this exciting time in the Family Court trying to empower families. Another exciting part was that some practitioners in Lower Hutt were developing family decision models for care and protection work. There was a lot of experimenting which I think was very worthwhile. On the other side we were dealing with youth justice children in the way we had always done. ${ }^{86}$

Around this time, Judge Carruthers was appointed as the sole judge for Porirua District Court, to sort out some of the difficulties there. He saw this as an opportunity to try out some new ideas. He had become interested in the work of a fellow judge, Mick Brown, in Waitakere Court. Judge Brown had been seeking ways to divert children to the local marae, and involve communities and families in finding solutions to dealing with children coming into conflict with the law. ${ }^{87}$ Judge Carruthers shared Judge Brown's faith in family and communities:

His (Judge Brown) big thing was that there was such strength and power in our communities that we are actually undermining what they are doing. We should be looking at the strength of family, hapu, iwi (and) playing back to them all the time. ${ }^{88}$

\footnotetext{
${ }_{87}^{86}$ Interview with Judge Carruthers dated 17 February 2010.

${ }^{87}$ Ibid

${ }^{88}$ Interview with Judge Carruthers dated 17 February 2010.
} 
This perspective resonated strongly with the voices of Māori, heard during both the consultations by the Māori Advisory Committee and the working party tasked with reviewing the Children and Young Persons Bill. Judge Carruthers was able to take advantage of his appointment in Porirua to start a pilot project with the view to involving local families and communities in the running of court matters, particularly related to children. He and a few interested court officials started going around the community to discuss how best to work with children who were appearing in courts:

We tried to change the way in which the court was working. We picked up some wonderful Samoan and Māori community-based people who were part of the court. If a child was arrested, they would find the family and they would organise a family meeting. In a way it was a pilot pre-cursor to the 1989 [legislation].

It was very exciting and felt very good. It meant letting go of a lot of things that we had done in the past and meant not trying to be the 'big bad judge' who will come down heavily on you like a ton of bricks. We were actually trying to get the right people who could work with the families and who could do that a lot more effectively because they were with them all the time. We were only there momentarily. ${ }^{89}$

Judge Carruthers recalled meeting with Maxwell around the time he was piloting the community-based approach to dealing with children in conflict with the law at the Porirua Court. He was interested in her expert opinion in relation to what they were doing and invited her to attend his court as an observer, which she did.

The connections forming between influential people who shared similar values and ideas during the time the working party were reviewing the Children and Young Persons Bill, (such as Judge Brown, Judge Carruthers, Maxwell, Renouf and Doolan), helped to shape to the thinking for the new Bill. They added to the credibility of community-based options that favoured the involvement of families in decision-making about their children over the multidisciplinary professional Denver-Colorado model being proposed in the draft legislation.

\footnotetext{
${ }^{89}$ Interview with Judge Carruthers dated 17 February 2010.
} 


\section{Establishing the new youth justice jurisdiction}

Renouf et al (1989) noted that the issue of creating a distinct youth justice system aimed at holding children and young people to account for their actions enjoyed wide acceptance. It was generally considered preferable to establish separate jurisdictions for youth justice and care and protection, which at the time were both still being heard in the Children and Young Persons Courts. The challenge was how to separate them. It was still recognised that children in conflict with the law were vulnerable members of society, and youth justice policies needed to reflect and provide for this, including if they were to be found in need of care and protection via the youth justice channels. The Justice Department made it clear that in their view it would not be appropriate for youth justice matters to be heard in the Family Court. Their submission referred to the positive developments in the Family Court that had come into effect in the early 1980's and were proving popular and successful in terms of better family and community involvement in resolving Family Court matters. Whilst there was general agreement that the Children and Young Persons Courts should be disestablished and that care and protection matters should be shifted to the Family Court, the Justice Department expressed concern that bringing criminal matters into the Family Court jurisdiction would destabilise its success: "Criminal jurisdiction is totally at odds with the current Family Court ethos. It brings connotations of fault and punishment...grafting criminal jurisdiction onto Family Courts would change the nature of the courts so undoing the good work of the last six years" (Nixon, 1987:4).

Nevertheless, the recommendation made by the working party on the Children and Young Persons Bill (1987) was to link the Youth Court to the Family Court rather than the District Court which dealt with adult criminal matters. One reason for this was that the Family Court had better skills and experience in general in dealing with children, young people and their families. It was also to respect the wish of Māori and Pacific Island families who believed that linking the Youth Court to the District Court would quickly result in over-criminalising youth, emphasising punishment rather than reintegration and community support in preventing re-offending. The working party thought that judges presiding over the Youth Court could come from both Family Courts and District Courts "on the basis of interest and expertise" (Department of Social Welfare, 1987:67-69). 
In the end, the Youth Court was established as a separate sub-division of the District Court with the appointment of its own Principal Youth Court Judge. ${ }^{90}$ Any judges appointed to preside over the Youth Court had to illustrate that they were "suitable to deal with matters within the jurisdiction by means of his or her training, experience and personality and understanding of the significance and importance of different cultural perspectives and values" (Brown, 1992:7). Appearances before the Youth Court were reserved for serious cases, and more minor offending by young people should be dealt with outside of the criminal court procedure (Judge Brown, 1992:30). This was a fundamental principle in New Zealand's youth justice system design.

\section{The Department of Justice considers the Mäori perspective}

Trying to understand the issue of crime committed by young people, and particularly by Māori youth, was not limited to the Department of Social Welfare during the 1980's. In 1987, a report was prepared by Moana Jackson from the Department of Justice's Policy and Research Division entitled 'Māori and the Criminal Justice System - A New Perspective: He Whaipaanga Hou' (Morris, 2004:256). While this report did not specifically look at addressing the needs of Māori children under 17 years of age, it was concerned with young Māori between the ages of 15-24, who were disproportionately represented in the criminal justice system (Jackson, 1987). Jackson wanted to research this matter from a Māori perspective. To do so, he also undertook an extensive process of community consultation and discussion: "From their perceptions of the justice system may come some insights into its impact on Māori people and the seeds for positive amelioration of these effects" (Jackson, 1987:11). In his report Jackson (1987) questioned the legitimacy of 'one law for all', given that New Zealand legislation was primarily founded on British law, and therefore did not accommodate Māori values and traditions. Following from this Jackson believed that in order to understand the causes of offending by Māori:

The first supposition is that research must view the Māori offender as an entity quite distinct from the Päkeha offender. He is a person who is shaped by the cultural forces which are unique to his being Māori, and who is subject to particular influences which are consequent upon that sense of Māoriness (Jackson, 1987:39).

\footnotetext{
${ }^{90}$ Email correspondence with Mike Doolan dated 26 January 2010.
} 
This comment by Jackson about Māori resonates with Bronfenbrenner's concept of the macrosystem, in that it suggests that there is a set social code understood by Māori, which differs from the western or British social standards and worldview. As such, Jackson contended that given there is a unique set of influences that shape young Māori, offending behaviour by Māori needs to be addressed through a uniquely Māori response.

The then Minister of Justice Geoffrey Palmer noted that the 'new perspective' proposed by Jackson may result in a "criminal justice system which is truly 'equal for all”" (Jackson, 1987:6). Nevertheless, the government did not intend for the 'new perspective' to result in a separate justice system for Māori, either for children or adults. The government still wanted a single justice system that could accommodate the needs of all New Zealanders.

\section{Designing the FGC process for youth justice}

While Māori families were the most vocal in matters relating their children and young people during the consultation process, involving families in decision-making about their children and young people was considered desirable for families from any culture or community. This notion therefore became a uniting feature when considering how to create 'one law for all'. The aim of the youth justice FGC was to provide a forum where effected parties (including young people, their families/support people and victims and their families/support people) could meet to discuss and resolve the offending. This was to allow young people to recognise the impact of their behaviour, to be held to account and to take responsibility to repair the harm with the support of the family. Hall described the intention of FGCs as:

Something that the family could come with others to talk about what 'Tommy Tuck' was doing. It was intended to be a time for a family to gather in the collective sense, bringing together the strengths of that whanau, whatever they look like: 'So what can be done about this child?' 'What can we do to help you and this child?' It was intended to be a way of helping helpless, Māori families feel less helpless, because they had their own family with them and we could talk to the children. So that's what it was intended to be: a way of taking the disempowered and empowering them to have input. ${ }^{91}$

\footnotetext{
${ }^{91}$ Interview with Donna Hall dated 20 March 2010.
} 
FGCs were inspired to some extent by traditional Māori practices of conflict resolution, particularly the concept of korero tahi.$^{92}$ Joan Metge, a social anthropologist who studied Māori customs, beliefs and traditions for some decades, explained that korero tahi was a process which brought parties together to talk through issues and come to a joint resolution (Metge, 2001: 12). She noted that this could include "the making of decisions or recommendations...in the investigation of wrongdoing and the administration of restorative justice and in conflict resolution" (Metge, 2001:12). The policy makers wanted to create a model that would be flexible enough to accommodate the multi-cultural nature of New Zealand society without having to create separate youth justice systems. Therefore, the approach was intended to provide a basic framework to conduct the process, allowing the details of each case, including the running of the conference and the outcomes, to be determined by the interactions between the participants. This included any cultural preferences or considerations (Daly in Morris and Maxwell, 2001:65). The aim was for each youth justice FGC to be unique to its specific set of circumstances and decisions on how best to make amends for the offending and support children and young peoples' rehabilitation and reintegration in the community.

Policy makers also decided to create opportunities for FGCs to be called for at several different points after young people enter the youth justice system. This could be as an alternative to court through an "Intention to Charge" FGC, or at various times after being referred to a youth court. The intention was to provide ongoing opportunity to uphold the following principles:

- Criminal proceedings should not be used if there is an alternative means of dealing with the matter;

- Measures to deal with young offenders should strengthen family groups and foster their skills to deal with offending by their children and young people; and

- Young people should be kept in the community as far as is consonant with public safety. $^{93}$

FGCs were also reserved for more serious offending rather than for minor or petty offending, the majority of which would be diverted early and dealt with through alternative actions administered by Police Youth Aid. This became a significant feature of the New Zealand's

\footnotetext{
${ }^{92}$ Meaning 'talking together'

${ }^{93}$ Section 208 of the Children Young Persons and their Families Act of 1989
} 
youth justice approach as it aimed to limit children and young people's exposure to the youth justice system as much as possible to avoid the risk of being labelled as criminals.

Doolan recalled how easily the youth justice provisions were eventually accepted by the government after years of toil on a piece of legislation that was different to anything that had previously existed in New Zealand:

When the matter went to the House for the second and third reading, the government of the day offered the opposition a four hour debate. Now that's unheard of -after all the angst about this legislation, they agreed to have a four hour debate...there was pretty much unanimity from both sides in the House...I don't recall in relation to the youth justice provisions that there was any significant debate about those other than 'this looked good, and we're going to do it'. 94

The proposed title of the Bill submitted to Parliament in April 1989 was the 'Families, Children and Young Persons Act' to reflect the emphasis on the involvement of the family group in matters pertaining to children and young people (Review of the Children and Young Persons Bill, 1987:34). The Act eventually came into force on 1 November 1989 as the Children, Young Persons and their Families Act 1989 (CYPF Act).

In his valedictory speech in 2009 when retiring from government two decades after the passage of the Children Young Persons and their Families Act, Minister Cullen reflected:

\section{The highlight of my time as Minister of Social Welfare was to rewrite a flawed Children and Young Persons Bill and to produce the 1989 Act which has stood the test of time in its basics and will continue to do so providing it is properly resourced. (Cullen, 2009)}

New Zealand was able to design an innovative new youth justice paradigm following input from widespread community consultation, particularly with Māori families who had historically been most negatively affected by New Zealand's social welfare policies. The most important defining features of this legislation were the increased opportunities for diversion, the establishment of a youth justice system distinct from care and protection, the importance of including young people's families in decision making processes particularly

\footnotetext{
${ }^{94}$ Interview with Mike Doolan 7 April 2010.
} 
through the FGC and the importance of victim considerations when responding to the offending in order to repair harm. While there have been some amendments made to the CYPF Act since it came into force, New Zealand has not tampered with its original core values and principles.

\section{South Africa}

Children have a right not simply to survive and not simply to develop; they have a right to be happy; they have a right to have adventure and to explore. Again, this is particularly pertinent in South Africa where the adventure of so many South African children has been the adventure of death, confrontations, violence, escaping the state, teargas, bullets, sjamboks ${ }^{95}$, prison - not the kind of adventure that is appropriate anywhere in the world for persons of any age, and it is certainly not appropriate for children to grow up like that. ${ }^{96}$

(Sachs, 1994:2)

South Africa's Child Justice Act 75 of 2008 came into force in March 2010. It took 14 years for South Africa's youth justice legislation to pass following the end of apartheid in 1994. While this was approximately two decades after New Zealand's Children, Young Persons and their Families Act of 1989 was passed, the development of South Africa's youth justice legislation effectively dovetailed with the process of youth justice transformation in New Zealand. It was influenced by some of the New Zealand's legislations' key concepts, values and principles, which had become more clearly framed thanks to the passage of time and academic scrutiny.

\section{Previous legal provisions for children in conflict with the law in South Africa}

Prior to the end of apartheid, laws relevant to dealing with children who commit crimes were contained in the Child Care Act of 1983 and the Criminal Procedure Act of 1977. Legislation existed during the apartheid years to ensure that children were kept separately from adults in detention. However, it did not specifically require children in detention to be treated differently to adults. The Criminal Procedure Act of 1977 included some provisions for

\footnotetext{
95 A heavy whip

${ }^{96}$ Albie Sachs who was a prominent political activist and judge of the Constitutional Court of South Africa, during a conference entitled "The Right of a Child to a Secure Family Life"- Proceedings of the International Seminar of the Community Law Centre at the University of the Western Cape 25-27 March 1994.
} 
juveniles, such as the requirement for hearings to be held in camera. This law noted that attempts should be made to contact parents when children were in conflict with the law. However, there was no obligation to do so, particularly if parents were outside of the magisterial district or could not be easily traced. Therefore some children could be arrested, tried and detained without the knowledge of a parent or guardian (McLachlan: 1985). This was particularly convenient for the government during the 1980s when children were increasingly being arrested and detained in prison without trial. At that time, sentences that could be imposed on children between the ages of 7 and 18 included the death sentence, imprisonment (including periodical imprisonment), committal to an institution established by the law, fines and whipping. There were some sentences only available to juveniles, which included probation under the supervision of a probation officer, placement in the custody of any suitable person and reform school (McLachlan: 1985).

\section{Ongoing abuse of children in the criminal justice system}

By 1990 South Africa was taking significant steps to dismantle its apartheid system following the unbanning of key opposition political parties and the release of Nelson Mandela in February that year. Shapiro-Liu had begun working in collaboration with Lukas Muntingh, a sociologist who had been hired by NICRO as a researcher in Cape Town. ${ }^{97}$ They had become aware of Skelton's child justice efforts to divert children from the criminal justice system through Lawyers for Human Rights in Durban, and decided to set up a "parallel process" in Cape Town, whereby they would convince prosecutors to put youth offenders through a programme set up by NICRO as an alternative to prosecution. ${ }^{98}$ These initiatives in Pietermaritzburg and Cape Town became the first seeds of diversion and key steps towards significant changes in the youth justice system. NICRO developed a life-skills programme for children in conflict with the law which eventually became known as the Youth Empowerment Scheme (YES programme). ${ }^{99}$ Some youth were also required to do community service as a consequence of their offending.

Muntingh was responsible for looking into what was happening in the youth justice field internationally. This research included a visit to America where he met Howard Zehr. Zehr had been gaining recognition as a key figure in the restorative justice movement after

\footnotetext{
${ }^{97}$ Interview with Rosemary Shapiro-Liu dated 11 February 2011; Interview with Dr Ann Skelton dated 28 September 2009; Interview with Lukas Muntingh dated 1 October 2009.

${ }^{98}$ Interview with Rosemary Shapiro-Liu dated 11 February 2011.

${ }^{99}$ Originally known as the Youth Offenders Programme (YOP)
} 
publishing his book on restorative justice, Changing lenses: A new focus for crime and punishment in 1989. ${ }^{100}$ Muntingh brought the concept of restorative justice back to his colleagues at NICRO who subsequently started a straightforward victim-offender mediation programme. While experimenting with these alternative options Muntingh recalled:

I came across an article about what was then a new word called 'diversion'. I said to my colleagues, 'our victim-offender mediation programme and this life-skills programme are diversion programmes, and the more that we have of them, the better'...they need to be focused on the particular needs of children. ${ }^{101}$

Michelle Morris, an American academic interested in youth justice working at CLC, had started a separate project called 'youth advocates' which involved law students going to court to assist young people. ${ }^{102}$ Shapiro-Liu met Skelton and Morris at a conference on youth justice arranged by CLC in the early 1990s. Discovering the extent of their shared interests, Shapiro-Liu invited them to her office in August 1992 to begin discussing their vision for a youth justice system in South Africa. Shapiro-Liu recalls that they wrote up the key points on the back of a serviette, which included:

Number 1- we need to get a juvenile justice system for the country;

Number 2-there need to be programmes to keep kids out of the criminal justice system and make them accountable;

Number 3-(children need) to be assessed, when they went into the criminal justice system they had to be checked out in some way. ${ }^{103}$

Thereafter, they concentrated their activities on promoting these three key areas. This involved a combination of developing credible alternatives for youth in conflict with the law which could be supported through research and promoted via strategic advocacy initiatives. However, these members of civil society remained concerned about the ongoing abuse of children in detention. In October 1992, the brutal killing of a young male, Neville Snyman by his cellmates in prison (Human Rights Watch, 1994: 76) enraged child justice activists,

\footnotetext{
${ }^{100}$ Interview with Dr Ann Skelton dated 28 September 2009.

${ }^{101}$ Interview with Lukas Muntingh dated 1 October 2009.

${ }^{102}$ Interview with Dr Ann Skelton dated 28 September 2009; Interview with Rosemary Shapiro-Liu dated 11 February 2011.

${ }^{103}$ Interview with Rosemary Shapiro-Liu dated 11 February 2011.
} 
and created a platform for their cause in the form of a campaign entitled 'Justice for the Children - No Child Should Be Caged'. A campaign report was compiled by the Community Law Center (CLC) at the University of the Western Cape in collaboration with NICRO and Lawyers for Human Rights. Shapiro-Liu explained:
He (Neville Snyman) was killed because after his aunt came to visit him he went back to the cells and didn't take any chocolates or treats to the people in the cell. They were all children and they murdered him. They tortured him in various ways and they murdered him. We said, 'Never again'. We said 'Someone's going to die!' and it happened. We went wild about this and put together a programme called 'Justice for the Children-No Child Should Be Caged'. We got into every newspaper, radio, international - we just went absolutely ballistic! At that stage there started to be a rolling effect.

\begin{abstract}
About a year after this campaign was launched, Cheryl Frank, a social worker from Durban, became interested in youth justice when running diversion programmes for NICRO in Natal in 1993. Frank recalls being impressed by the active people she was meeting at that time through her work, including Skelton and Shapiro-Liu. She referred to them as "mentors" who influenced her thinking:
\end{abstract}

At that time I had been most worried about the harmful physical and emotional effects in the system. Kids were getting beaten up, raped, and obviously we had very extreme cases of that in other parts of the country. Where I was working, primarily there were issues of physical assaults and rape. My issue was to get them out of those conditions as soon as possible, and diversion offered a means to do that, although it wasn 't a comprehensive means. We did get some of them out, but there were lots of other children in the system. Diversion was an important notion to enter my head at the time. It was an important learning. My interest developed from there, and being inspired by these two people who I got to work very closely with in that first period. ${ }^{104}$

\footnotetext{
${ }^{104}$ Interview with Cheryl Frank dated 28 September 2009.
} 


\section{Key political activists become part of the new South African government}

When the African National Congress (ANC) became the first government elected by universal suffrage in 1994, a number of important political activists who had been working at CLC at the University of the Western Cape were appointed into key government positions as well as the newly established Constitutional Court. Among these was Dullah Omar, who became the Minister of Justice. Skelton noted:

\section{I don't know why I didn't predict that, but I didn't expect that Omar was going to be the Minister of Justice. I suppose I'd never thought about it because we were just 'beavering' away. Up until then, all the work was characterised as being 'anti-apartheid' and 'anti the government'. Now suddenly there was this whole huge opportunity created. ${ }^{105}$}

Dullah Omar's position made him instrumental in helping to advance the child justice cause. Youth justice was quickly placed on the new South African government's agenda due to the conditions faced by children in the criminal justice system during the apartheid years, the vast majority of whom were from oppressed racial groups. After these key political activists left the CLC to form part of cabinet, Julia Sloth-Nielsen was asked to join the CLC's Children's Rights project in April 1994. ${ }^{106}$ She explained:

The children's rights project was formed in 1990, along with the rest of CLC when returning exiles came back to write the Constitution. This was the institutional think tank of the Constitution writing process of the ANC. The people that were there at the time were Dullah Omar, Albie Sachs, Bulelani Ngcuka, Kader Asmal - everybody that went on to become either a Constitutional Court judge or a Cabinet Minister. We all started cold in 1994, because they all moved on. ${ }^{107}$

Pinnock had joined forces with Shapiro-Liu and Skelton to assist in the shaping of the new approach to youth justice. In 1994, around the time Nelson Mandela became president, Pinnock, Skelton and Shapiro-Liu drafted a document entitled 'Juvenile Justice for South

\footnotetext{
${ }^{105}$ Interview with Dr Ann Skelton dated 28 September 2009.

${ }^{106}$ Interview with Prof Julia Sloth-Nielsen dated 16 October 2009.

${ }^{107}$ Ibid
} 
Africa - Proposals for Policy and Legislation 1994/9', commissioned and supported by Minister Omar. Both Shapiro-Liu and Pinnock believed this document formed the foundation of official youth justice developments thereafter. ${ }^{108}$ In order to promote their proposal, Shapiro-Liu, Skelton and Pinnock organised a conference in Broederstroom for government and NICRO officials to explain and promote their vision. They noticed a number of ANC officials gathered for an ANC caucus at the same venue, including President Mandela. Shapiro-Liu managed to approach him and give him a copy of their proposal in person. She recalled:

I ran after him with my book...he paged through it and he said 'I've asked my government for something like this'. I said 'This is it!' He said 'Fantastic, is this from Minister Omar?' I said 'Yes. You are getting the first copy'. This conference is about presenting it to the NICRO people and to government. He said 'I'll read it tonight. Thank you so much'. 109

While this chance encounter enabled the activists to put their solutions to the issue of youth justice on the government agenda at the highest level, it was apparent from President Mandela's response that this was something he was genuinely concerned about, as noted in his inaugural speech.

\section{Tapping into the New Zealand experience}

In addition to working with Skelton and Shapiro-Liu in the early to mid-1990s, Pinnock was networking internationally to tap into ideas around youth justice policy that could be of assistance to South Africa. Skelton, described Pinnock as an "aficionado of email and internet" when the use of these modes of communication were still limited in South Africa. Pinnock reflected that they had previously been looking at several pieces of youth justice legislation from around the world, including from places such as America, Germany and Britain, but found that none of these jurisdictions had the "sort of restorative justice legislation that we approved of". ${ }^{110}$ Therefore, they turned to more indigenous justice practices in South Africa. There they found some of the inspiration they had been looking for in terms of identifying community models for conflict resolution which encouraged the participation of the affected parties in finding solutions to their problems.

\footnotetext{
${ }^{108}$ Interview with Rosemary Shapiro-Liu dated 11 February 2011; Interview with Don Pinnock dated 2 March 2011.

${ }^{109}$ Interview with Rosemary Shapiro-Liu dated 11 February 2011.

${ }^{110}$ Interview with Don Pinnock dated 2 March 2011.
} 
Skelton noted however that two people from outside South Africa responded to Pinnock's call for examples of demonstrating the application of restorative justice principles in youth justice practice. One of the respondents was Gabrielle Maxwell, who, at the time was conducting the first major research into the implementation of FGCs in New Zealand with Allison Morris (Maxwell and Morris, 1993). ${ }^{111}$ Maxwell recalls receiving the initial email from Pinnock in 1994 which was followed by subsequent correspondence inviting her to a conference on youth justice in South Africa. This conference was in response to Minister Omar's request for a committee of concerned individuals to draft legislation for youth justice. Maxwell, who was working with New Zealand's Office of the Children's Commissioner at the time, was keen to share the New Zealand model and her research findings with South Africans involved in the field. She sought support from Ian Hassall, who was the Children's Commissioner and received funding from New Zealand's Ministry of Foreign Affairs and Trade to attend the conference and meet with some of the South African child justice activists. $^{112}$

Maxwell travelled to South Africa in July 1994 where she recalled attending a workshop in Cape Town with approximately fifteen participants who were attempting to develop a proposal for a new law in South Africa about the treatment of young people who offended. ${ }^{113}$ She reflected:

\section{(The participants) were talking passionately from their hearts about what} they wanted... (I told them) about what we were doing in New Zealand and I got questioned for a long while. ${ }^{114}$

\footnotetext{
${ }^{111}$ Interview with Dr Ann Skelton dated 28 September 2009.

112 Maxwell outlines the formal programme for her visit to South Africa in her report to the Ministry of Foreign Affairs and Trade dated 17 August 2004 as including: "A seminar to a senior Criminology class at the University of Cape Town; An open lecture at the University of Cape Town attended largely by people from social service agencies, police and justice groups; A lecture at Durban Prison to which Justice and Welfare officials, Police, Prison staff and voluntary agency personnel were invited; A presentation in Johannesburg to a regional conference of workers at NICRO - an agency equivalent to the Prisoner's Aid and Rehabilitation Society here; A presentation to the staff of the National Welfare Department in Pretoria; A presentation to a National Conference in Pretoria organized for probation officers and others involved in the justice system to discuss new directions".

${ }^{113}$ This conference was held at the Institute of Criminology at the University of Cape Town. In attendance were members from CLC, Lawyers for Human Rights, NICRO, Cape Town Child Welfare, the Community Peace Foundation, and the Cape Provincial Administration.

${ }^{114}$ Interview with Dr Gabrielle Maxwell dated 29 March 2010.
} 
Skelton recalled:

We were intrigued by the fact that the Māori people had played a role in the development of the system in New Zealand, and we felt that it could resonate with African people here as well. We believed that, and it is definitely true. ${ }^{115}$

Following Maxwell's visit to South Africa, Pinnock, Skelton and Shapiro-Liu wrote an article entitled 'New Juvenile Justice Legislation for South Africa - Giving Children a Chance' (1994). ${ }^{116}$ That article described the problem of youth in conflict with the law, making reference to statistics from Africa Prison Watch at the end of 1992 that reported there were “16,459 sentenced and un-sentenced juveniles in prison" and "in 1993 alone 36,000 were sentenced to be whipped". It emphasised the need for principled youth justice legislation aimed at keeping children out of the criminal justice system. The article explained:

\section{After the UCT workshop, a handful of people remained to pull together the ideas. They were left with plans, problems, suggestions and a mandate to write a draft Bill, but still with no comprehensive programme. They began by drawing on the work of their committee, but also on legislation elsewhere in the world and on international instruments such as the United Nations Convention on the Rights of the Child, the Beijing Rules the OAU Declaration on the Rights of the Child, the South African Children's Rights Charter and the new interim Constitution.}

The article outlined the main areas the committee wanted included in new youth justice legislation and covered arrest, reception and referral, juvenile court, sentencing and custodial care. It also made special reference to the notion of including FGCs as a principal way of keeping children out of the criminal justice system. At this stage, they recommended that FGCs should be used for the majority of cases involving petty offending, which they estimated constituted approximately $70 \%$ of all juvenile offending in South Africa. They also proposed twelve principles which should underpin South Africa's youth justice legislation. The range of international and national influences noted above was clearly reflected in these principles. The principles were:

\footnotetext{
${ }^{115}$ Interview with Dr Ann Skelton dated 28 September 2009.

${ }^{116}$ University of Cape Town's Institute of Criminology Social Justice Research Project-Occasional Paper 3-94, 1994.
} 
- to protect children's access to basic rights such as food, shelter and education;

- to only use criminal proceedings as a last resort against juveniles;

- to ensure that juveniles are not discriminated against;

- children's vulnerability should afford them special protections;

- children's opinions should be heard and taken into consideration;

- due process should be followed in matters pertaining to juveniles;

- the involvement of family and community is central to the decision-making process affecting their children;

- children should take responsibility for their actions;

- age is a mitigating factor and a child's welfare should be taken into consideration in the decision-making process;

- victims should have the right to be involved in the decision-making process and have their interests considered;

- procedures and sanctions should be sensitive to cultural needs and values; and

- children in conflict with the law should be protected from publicity

(Pinnock, Skelton and Shapiro-Liu, 1994)

Pinnock noted that not only were they referring to key documents while developing the draft legislation, but they also used a live international interactive process which could help them work through the issues they were working on. He explained:

We sent out a lot of emails around the world noting the days we would be drafting the legislation and saying: 'We will be trying to codify the concepts around juvenile justice and we would appreciate your assistance'. We [exchanged] emails and sat in the Institute of Criminology with computers putting together this legislation. Every now and then there would be a 'ping' and some idea would come from some other part of the world...So the process was extraordinary in that it was being written internationally while we were doing it. ${ }^{117}$

As a result of the interest in New Zealand's youth justice system, a team of South Africans visited New Zealand with Maxwell's assistance to gain insights into how their systems were being run, particularly with regard to FGCs. Skelton and Frank were amongst the team who

${ }^{117}$ Interview with Don Pinnock dated 2 March 2011. 
visited New Zealand along with other members from NICRO and one from government in 1995. $^{118}$

\section{Establishing diversion from criminal proceedings as a credible option}

On 24 March 1995, the State versus William was heard in the Constitutional Court. This matter raised the question of the constitutionality of using whipping as a sentence for juvenile offenders before the Constitutional Court. The Constitutional Court ruled that the use of whipping as a sentence for juveniles should be abolished on the grounds that it was deemed unconstitutional. The Constitutional Court Judge Langa stated "it is my view that at this time, so close to the dawn of the $21^{\text {st }}$ century, juvenile whipping is cruel, it is inhuman and it is degrading. It cannot moreover be justified in terms of section 33(1) of the Constitution". (Case number 20/94 delivered on 9 June 1995) Once whipping was deemed unconstitutional by the Constitutional Court, most magistrates lost their preferred sentencing option, which was formerly administered immediately after sentencing with limited opportunity for review (Case number 20/94 delivered on 9 June 1995). According to Sloth-Nielsen, the removal of whipping as a sentence "threw juvenile justice into turmoil". 119

On 16 June 1995, Sloth-Nielsen held a seminar to look at the issue of the use of whipping as a sentence for child offenders following an initiative by the Regional Court Magistrates. The advantage of this Constitutional Court ruling for the youth justice movement was that magistrates now had to seriously consider using the diversion options that had been developing around the Western Cape and Natal as an alternative to whipping. ${ }^{120}$ The abolition of whipping gave the child justice advocates a gap to promote the concept of diversion to magistrates using evidence from practice that was already being implemented in some parts of South Africa, such as videos of life-skills sessions being held by NICRO social workers. ${ }^{121}$ Muntingh recalled that prosecutors were initially unsure about the new approach civil society was proposing and that it took some effort to convince them:

What was very evident from that very early stage was that the majority of prosecutors were not interested - they didn't understand it. There was a

\footnotetext{
118 This international exchange of ideas and experiences between New Zealand and South Africa will be discussed further in this thesis, in particular in Chapter 10 which looks at policy transfer between New Zealand and South Africa.

${ }^{119}$ Interview with Prof. Julia Sloth-Nielson dated 16 October 2009.

${ }^{120}$ Ibid

121 Ibid
} 
whole apprehension around diversion programmes. There were certainly doubts and questions around it. I think what we did well was to provide them with information and structure, to engage with them, and say, 'you know it's not all that threatening and the state won't collapse if you divert children and there are safeguards and procedures'. I think from there, the process picked up momentum. ${ }^{122}$

\section{The Inter-Ministerial Committee for Young People at Risk}

On 8 May 1995, the South African government made a dramatic move, releasing over 2,000 children remanded in custody. This decision came as a result of an amendment made to Section 29 of the Correctional Services Amendment Act 17 of 1994 stating that no children below 18 years of age should be detained in prison or police cells awaiting trial. The intention was to demonstrate the government's commitment to only using prison as a last resort for children awaiting trial. However, there were insufficient places of safety available and no backup systems in place to accommodate children following their release or to secure their court appearances. This issue exposed how unprepared the government was to safely accommodate the number of children remanded in custody in the community, highlighting the need to develop alternatives. As a result, an Inter-Ministerial Committee for Young People at Risk (IMC) was established in 1995 to respond to the needs of children awaiting trial. The IMC comprised of members from the ministries of Social Welfare, Justice, Correctional Services, Safety and Security, Education and Health, Labour, and

Reconstruction and Development as well as the key NGOs already involved in the process of youth justice transformation. A series of pilot programmes initiated by the IMC under the Minister of Social Welfare, Geraldine Fraser-Moleketi provided opportunities for diverting children and youth from court and custody. Section 29 of the Correctional Services Amendment Act was further amended in 1996 allowing court discretion to remand children in prison or police cells between the ages of 14 to 18 if they had been charged with committing a serious offence. However, children below the age of 14 could still only be detained in a place of safety.

The IMC soon realised that the issue of children in conflict with the law was a complex problem that went beyond simply looking at offending behaviour and alternatives to detention. As a result they made their objective the: "designing and implementation of an

${ }^{122}$ Interview with Lukas Muntingh dated 1 October 2009. 
integrated child and youth care system based on a developmental and ecological perspective" (IMC, 1996). This broadened the definition of 'children at risk' officially recognising that offending behaviour by children and youth was a symptom of larger systemic problems that needed a multi-dimensional response. This perspective resonates with Bronfenbrenner's ecological explanation of the impact of interactions between multiple social systems which has an influence on children's development, thereby requiring this to be reflected in any policy making that affects children and young people. This coincided with the increased interest in children's rights in South Africa in general, beyond the initial focus on child justice. $^{123}$

In their document entitled 'Interim Policy Recommendations' (1996:15-17) the IMC outlined a set of operating principles to frame their approach to dealing with the problem of children and youth at risk. These were the principles of:

- Accountability for the standards of service delivery

- Empowerment

- Participation of children and their families

- A family-centred approach to support and enhance the capacity of the family system

- A continuum of care for service delivery emphasising the most empowering and least restrictive interventions

- An integrated approach to service delivery amongst service providers ensuring the best use of combined capacity

- Continuity of care based on the child and family's evolving needs

- Normalisation which introduces processes that promote community integration and participation of the family and the child

- Effectiveness and efficiency

- Child-centred focusing on ensuring that any intervention is relevant and promotes a positive developmental experience for the child

- Upholding the rights of children as defined by the United Nations Convention on the Rights of the Child and the South African Constitution

- Restorative justice including accountability and making amends

- Appropriateness of interventions

- Promoting family preservation

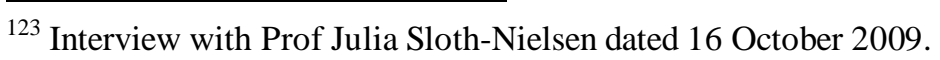


- Permanency of planning which aims to support the healthy development of children in their family environment

The 'continuum of care' approach for addressing children at risk from 'least restrictive' to 'most restrictive' aimed to identify issues ranging from care and protection to youth correctional services in order to consider points of need and intervention determined through what became referred to as a developmental assessment. ${ }^{124}$

The pilot projects implemented by the IMC relating specifically to improving youth justice facilities included FGCs (based on the New Zealand model) ${ }^{125}$ and the Arrest, Referral and Reception Centre at the Durban Magistrate Court with the view to providing an "assessment and intervention for every child under 18 years arrested in the Durban area" (Juvenile Justice Discussion Paper 79, 1999:18). It also included the One-Stop Justice Centre whereby all youth justice services including assessment, reception and referral were located close to each other to facilitate access and simplify the process for children and their families. Places of safety were also established. These were detention facilities for youth awaiting trial which aimed to ensure that good standards of practice were being maintained in line with international standards for children's rights. This included opportunities for their development and reintegration into the community (IMC, 1996).

\section{Formalising the law making process}

Minister Omar had worked alongside and supported key youth justice activists during his time as director of the CLC. While encouraging their proposals for changes to policy and legislation to transform the youth justice system, he was aware that in order for their ideas to become embedded in law, an official law making process was needed. ${ }^{126}$ As the new Minister of Justice, Omar suggested using the South African Law Reform Commission (SALRC) to formally draft the proposed youth justice legislation. ${ }^{127}$ Skelton stated that at the time she felt "a bit crest-fallen by that" stating:

\footnotetext{
${ }^{124}$ The Probation Services Amendment Act 35of 2002 introduced the legal provisions and framework for the developmental, strength-based assessment process using a restorative justice approach for children in conflict with the law pending the passing of the Child Justice Bill. This amendment Act defines 'assessment' as a process of developmental assessment and evaluation of a person and their family circumstances. This includes assessing the nature and circumstances around the alleged commission of an offence, its impact on the victim, the attitude of the alleged offender in relation to the offence and any other relevant factors.

${ }^{125}$ Interview with Mike Batley dated 30 October 2009

${ }^{126}$ Interview with Dr Ann Skelton dated 28 September 2009

${ }^{127}$ Ibid
} 
I didn't like the fact that he wanted to use what felt like some apartheid machinery that had been there all along to do this. I can now understand that he was seeing it as an opportunity to re-energise and transform these old institutions of government, and to make sure there was a rigorous process. $^{128}$

In 1997, the law reform group was put together. Skelton was made chair and Sloth-Nielsen was included as a vital member. ${ }^{129}$ Skelton described the composition as "unusual" because, apart from Sloth-Nielsen who was an astute legal academic, the members primarily came from civil society. Sloth-Nielsen explains that the reason for this was not only that the NGO sector had developed a proven expertise in the area of youth justice, but also because "they were suspicious of everybody who was linked to the former regime, which was the window of opportunity for people like Ann [Skelton] and myself to be put on". ${ }^{130}$

Skelton described her experience as follows:

For my own academic development that was a very important stage. [It meant] no longer just working on your instinct of what you knew must be right and trying to draw from UN instruments. Now we actually had to understand our own law and our own context. [We had to consider] the common law and how we were going to infuse these new ideas into our system and bring magistrates, prosecutors and people who were quite resistant to change along with us. We didn't use the word 'reform'. We used the word 'transform'. Everything was big brush strokes. You could do anything - that's what it felt like. ${ }^{131}$

By this stage they had a sense of what could work in the South African context. Skelton believed that there were specific advantages to the committee being primarily made up of the NGO sector, as they had been implementing and testing various ideas for some time, particularly around diversion. ${ }^{132}$ This was further strengthened by the establishment of the Child Justice Project in the Department of Justice in 1999. Skelton left the NGO sector to

\footnotetext{
${ }^{128}$ Interview with Dr Ann Skelton dated 28 September 2009.

${ }^{129}$ Interview with Prof. Julia Sloth-Nielsen dated 16 October 2009.

130 Ibid

${ }^{131}$ Interview with Dr Ann Skelton dated 28 September 2009.

132 Ibid
} 
manage this project for four years, thereby facilitating the blend of NGO and government ideas in the development of the youth justice approach in South Africa.

\section{Establishing the core principles and practice}

SALRC ultimately chose the term 'child' in the draft title of the legis lation rather than 'juvenile', 'youth' or 'young person'. This was to ensure consistency with the UNCRC where 'child' is defined as any person under the age of $18 .{ }^{133}$ The decision not to use the word 'juvenile' was also to avoid the negative connotations often associated with this term.

The Commission started its drafting process by consulting various government and nongovernmental agencies. They ran a series of workshops and put out an Issue Paper ${ }^{134}$ which included questionnaires for workshop participants relating to youth justice procedure. The findings from this Issue Paper were then deliberated upon with input from national and international experts. These discussions resulted in a Discussion Paper for the purpose of another round of consultations with government and NGO representatives. ${ }^{135}$ In the spirit of giving children a voice in the process, the Commission also consulted with children about issues pertaining to children in conflict with the law and incorporated their views when drafting the legislation. ${ }^{136}$ In July 2000, the SALRC released the 'Juvenile Justice Report Project 106', explaining the findings from the Issue Paper and the Discussion Paper, as well as identifying needs and making recommendations for juvenile justice law reform.

\section{Promoting the Child Justice Bill}

The drafting of the Child Justice Bill was completed in early 2001. Prior to this, Jacqui Gallinetti had spent some years working at the University of Cape Town's Legal Aid Clinic as a lawyer. One of her responsibilities during this period was to provide legal aid to children appearing at the Wynberg Magistrate's Court in Cape Town as well as in the Children's Court dealing with matters of care and protection. As such, Gallinetti had exposure to

\footnotetext{
${ }^{133}$ Chapter 3 of the "South African Law Reform Commission Report on Juvenile Justice" - July 2000. This proposal was made as a result of the general consultation process which included the issue of terminology. ${ }^{134}$ Issue Paper 9 of 1997

135 "South African Law Reform Commission Report on Juvenile Justice" - 2000:4. According to this report, groups consulted with included "the Department of Correctional Services, a variety of non-governmental organisations and representatives from various statutory Commissions, the Department of Safety and Security, the Department of Justice (both practitioners and policy-makers), NICRO, the Department of Education, intersectoral organisations and the Department of Welfare and Population Development. In addition, various briefings were held with the members of the Portfolio Committees of the Departments that would be responsible for implementation of the legislation, namely Justice, Welfare and Population Development, Safety and Security and Correctional Services".

136 "South African Law Reform Commission Report on Juvenile Justice" - 2000
} 
children's needs in a range of contexts. ${ }^{137}$ This experience provided her with a good foundation taking on a position at CLC in early 2001 to promote the Child Justice Bill and facilitate its introduction to Parliament. ${ }^{138}$ Gallinetti recalled:

There was a certain amount of concern that the Bill might not receive the necessary support from government and the legislature as well as the public, because crime is a big issue and the general perception is that 'children are the only ones who commit crime' to some extent. ${ }^{139}$

Soon after Gallinetti's appointment at CLC, the Child Justice Alliance was established under the direction of the Child Justice Project. While this Alliance comprised a driver group of key role players, it was designed to include any members of government, NGOs and individuals interested in the principles enshrined in the Bill. Gallinetti was responsible for leading the Alliance as well as raising awareness about the Child Justice Bill around the country:

It was about making people aware within the children's rights arena, the child justice arena and also to a large extent within the broader community. The messages were that this is a piece of legislation which is rights-based because of the fact that children are vulnerable. That it's a procedural system that tries to balance the rights of children with their responsibilities and that it has a preventative nature with diversion and restorative justice. That's essentially how it started and it just snowballed from there. ${ }^{140}$

Gallinetti's personal experience as a children's defence lawyer when diversion was being introduced served her well during her awareness campaign around the country. She was able to use examples from her practice to explain the benefits of the system she was trying to promote. Gallinetti found this particularly useful when meeting with magistrates who respected her experience as a lawyer with first-hand knowledge of the existing system. ${ }^{141}$ It was Gallinetti's experience of a client she named 'Gavin' that convinced her of the principles of the Bill. She explained that 'Gavin' had initially been arrested for housebreaking. His mother refused to have him at home on remand as she found him 'out of control'. As a result,

\footnotetext{
${ }^{137}$ Interview with Dr Jacqui Gallinetti dated 15 October 2009.

138 Ibid

139 Ibid

140 Ibid

141 Ibid
} 
he was held at Pollsmoor Prison in Cape Town where he was gang raped by fellow inmates. Gallinetti reflected:

I realise crime is a problem, I realise legal certainty, particularly about processes is important, but you have to weigh that with the individual child that's[sic] who's going through these sorts of things. ${ }^{142}$

Strengthening the child justice campaign, Muntingh had conducted a longitudinal evaluation of NICRO's YES life-skills diversion programme in 1997 and 2000, primarily looking at the long-term benefits of this diversion process. This research found that after three years there was only a $7 \%$ recidivism rate for the children who had been through this programme. Muntingh noted that these findings became a significant tool for swaying the opinion of the sceptics. ${ }^{143}$ Muntingh acknowledged: "Those stats became mantras...It was important for people to have some sense that there is some growth in what we were doing - that children are [sic] were being diverted". 144

\section{Preparing for Parliament}

While the members of SALRC felt confident that they had good evidence to support the proposed legislation, they were aware that the financial cost of implementation would be questioned. Therefore, in preparation for the hearings on the Child Justice Bill, the Department of Justice's Directorate of Children and Youth Affairs coordinated a costing exercise for the Bill which was released in October 2002. ${ }^{145}$ The purpose of costing the Bill was to illustrate how funding would be distributed under the new Bill and the ultimate savings that would result from the proposed approach to child justice. Whilst there had been a costing exercise during the Law Commission's process, this one was more comprehensive and aimed to provide a realistic idea about how much the required budget for the proposed system would be. Advocate Vusi Pikoli, the then Director-General for Justice and Constitutional Development stated that the "process for planning for the implementation of the Child Justice Bill has been highly innovative and sets a good example for every piece of

\footnotetext{
${ }^{142}$ Interview with Dr Jacqui Gallinetti dated 15 October 2009.

${ }^{143}$ Interview with Lukas Muntingh dated 1 October 2009.

144 Ibid

145 The Directorate of Children and Youth Affairs set up an inter-sectoral forum called the Inter-Sectoral Committee for Child Justice which included the National Prosecuting Authority, the Department of Social Development, the Department of Correctional Services, the Department of Education, the South African Police Service, the Office of the Rights of the Child, the Presidency. An economist assisted the committee. This process resulted in a report entitled "The Child Justice Bill-Budget and Implementation Plan"
} 
legislation that comes before Cabinet and Parliament". ${ }^{146}$ The costing process was aided by the fact that many aspects of the Child Justice Bill were already being implemented providing good insights into the actual costs of existing practice. ${ }^{147}$

The Child Justice Alliance also wanted to provide a children's view on the proposed Child Justice Bill, again, in line with children's right to participation. As a result, the Alliance published the "Children's Perspectives on the Child Justice Bill” in January 2002. This document was based on the views of children at "various stages of the criminal justice system", ${ }^{148}$ as well those with no personal experience of the criminal justice system.

In December 2002, South Africa's Department of Correctional Services released a power point presentation noting that at 31 December 2002 there were still 2,371 un-sentenced and 1,765 sentenced children in prison. This clearly indicated that by the time the Child Justice Bill was ready to be presented to the Portfolio Committee early in 2003, the problem of children in custody, especially those remanded in custody, still needed to be addressed. When the submissions for the Child Justice Bill 49 of 2002 were ready to be heard by the Portfolio Committee for Justice and Constitutional Development in February 2003, the members of the Child Justice Alliance, (which included the key role players over the years as well as the members of the SALRC), felt they had their bases covered. A number of submissions were made by various civil society organisations, mostly in support of the proposed legislation. Sloth-Nielsen prepared an overarching written and oral submission designed to illuminate the Portfolio Committee on child justice needs, the process of developing the Bill and the purpose of the Bill. ${ }^{149}$

\section{Bifurcation stalls the process}

Supporters of the Bill hit a wall when the Chairperson of the Portfolio Committee for Justice and Constitutional Development, Johnny De Lange, advised that he did not support all aspects of the Bill, particularly with regard to the idea that diversion should be an option available to all children irrespective of the nature of their offending. He believed that it would not be possible for the Portfolio Committee to sell this concept to the general public for

\footnotetext{
${ }^{146}$ Foreword to the "Child Justice Bill Budget and Implementation Plan" by Vusi Pikoli

147 "Child Justice Bill Budget and Implementation Plan" - October 2002:10.

148 "Children's Perspectives on the Child Justice Bill” Methodology - January 2002

${ }^{149}$ Personal observations made while attending the Portfolio Committee for Justice and Constitutional Development hearings on the Child Justice Bill 49 of 2002 in February 2003
} 
children who had committed serious offences such as rape and murder. ${ }^{150}$ De Lange's position fundamentally undermined the ethos of the Bill and was considered one of the greatest challenges to the process of youth justice transformation by most of the role players interviewed. ${ }^{151}$ Skelton explained De Lange's influence as being "much more than one person. He carried that whole Committee". ${ }^{152}$ It is not clear why he wielded this much power over the Committee, but it was evident that the Committee members did not significantly challenge his concerns at the time.

Skelton acknowledged that De Lange supported the Bill's restorative justice framework, particularly as it referred to repairing the harm experienced by victims. She also noted that he was not against the notion of diversion per se, but because he was not in favour of the option of diversion being available for all categories of offenders, he proposed what became referred to as a 'bifurcation' of processes. This meant that the option to divert a case would only apply to certain categories of offenders, and that under no circumstances should serious offenders be considered for diversion from the criminal justice system or for restorative justice interventions. This position created a fundamental rift between the Portfolio Committee headed by De Lange and the promoters of the Bill. Gallinetti described the experience as follows:

We were lulled into a false sense of security...in those first years, 2001 and 2002, in all our dealings with government, Social Development, Justice, the NPA (National Prosecuting Authority), they were all on board...They fully supported the content of the Bill....It was fantastic! It was this little 'Ra! Ra!' delegation that went to Parliament. Government and civil society were a single voice almost. And then suddenly you got the Chairperson of the Portfolio Committee who put the skids on everything. So it did, to a certain extent, blindside us. ${ }^{153}$

While De Lange's position regarding the differences between children who commit serious offences versus those who commit minor offences was understood, child justice advocates considered 'bifurcation' flawed in two ways in particular. One was that it undermined the

\footnotetext{
${ }^{150}$ Personal observations made while attending the Portfolio Committee for Justice and Constitutional Development hearings on the Child Justice Bill 49 of 2002 in February 2003

151 This included Dr Ann Skelton, Prof. Julia Sloth Nielsen, Rosemary Shapiro-Liu, Don Pinnock, Lukas Muntingh, Cheryl Frank and Dr Jacqui Gallinetti.

${ }^{152}$ Interview with Dr Ann Skelton dated 28 September 2009.

${ }^{153}$ Interview with Dr Jacqui Gallinetti dated 15 October 2009.
} 
Bill's intention to treat all children who offend from the same "philosophical departure point" such that one could "cross that divide and you could still be looking at restorative possibilities even if you were talking about murder ... (and) that your aims for your system would still be the same no matter who you were dealing with". ${ }^{154}$ The other flaw in bifurcation was that not offering diversion to serious offenders meant that they would not have the same opportunity to address their offending behaviour. Gallinetti referred to a point Muntingh had made that "it's not a question of some children being more children than other children". 155

The Portfolio Committee for Justice and Constitutional Development headed by De Lange rewrote large aspects of the Bill in line with the 'bifurcated' approach. The new version of the Bill was not accepted by the key members of the Child Justice Alliance, resulting in a stalemate and the Bill being shelved for approximately five years. The momentum that had been achieved in Parliament had effectively come to a standstill.

\section{Key role players keep the original principles alive}

The Child Justice Alliance continued to grow in strength and numbers during the parliamentary hiatus. The advocates sought evidence to convince the government and ultimately the public that their proposed approach would be the best outcome for South African children in conflict with the law. ${ }^{156}$

... the whole idea behind the Alliance when it started was to be a support for the Child Justice Bill through the Parliamentary process. Then suddenly you were faced with a period of time when the Bill wasn't in Parliament. So what do you do for four years? We started realising that we needed to do research, and that's when we started our research function. ${ }^{157}$

While it was unclear as to what, if anything was going to happen with the Child Justice Bill, there were ongoing attempts to keep the principles of the Bill alive through various civil society and academic bodies. NGOs such as NICRO continued to offer diversion programmes to children diverted by prosecutors, the National Department of Social Development (DSD) offered support and implemented strategies such as various one-stop

\footnotetext{
${ }^{154}$ Interview with Dr Ann Skelton dated 28 September 2009.

${ }^{155}$ Interview with Dr Jacqui Gallinetti dated 15 October 2009.

${ }^{156}$ Interview with Dr Ann Skelton dated 28 September 2009.

${ }^{157}$ Interview with Dr Jacqui Gallinetti dated 15 October 2009.
} 
centres and secure care facilities and concerned university departments and institutes conducted evaluations and other forms of research to gather evidence that would be useful to the cause. Training of probation officers, ${ }^{158}$ prosecutors and magistrates ${ }^{159}$ in the principles of the Bill increased during this period. The aim was to disseminate and implement the principles of the Bill as widely as possible. The Alliance also tried to keep child justice on the government radar by maintaining liaisons with relevant government officials from Justice, Social Development, and the National Prosecuting Authority. ${ }^{160}$ Upon reflection, Frank felt that while they were making efforts to keep the principles of the Bill alive, the Alliance's strategy to remain cordial with the government and the media rather than push more aggressively for what they wanted, started to take its toll on core members of the Alliance. ${ }^{161}$

Pinnock was no longer primarily involved in the child justice movement by this stage.

However, his interest in the area continued. He remained active through an NGO he had initiated called Usiko which provided diversion programmes in line with the principles of the proposed child justice legislation. Usiko offered an intensive alternative to detention using Pinnock's concept of rites of passage for young offenders (discussed in Chapter 4). This was an area Pinnock had conducted research into and continued to advocate for during his career. ${ }^{162}$ He also maintained contact with Skelton in particular, and was kept aware of the status of the Bill in Parliament. He used his skills and position as a journalist to raise concerns via the media. ${ }^{163} \mathrm{He}$ recalled:

\section{I started to put stuff in the Mail and Guardian ${ }^{164}$ and any newspaper that would take it. Basically the Child Justice Bill had been shelved. I'd like to think that those processes dragged it back into the light, because I was arguing for six or seven months - I was really hammering hard! It was in}

\footnotetext{
${ }^{158}$ Training of probation officers was mostly conducted through the University of Cape Town's Department of Social Development with the support of the government Department of Social Development. A number of amendments were made in the Probation Officers Amendment Act (no. 35 of 2002) which included conducting developmental assessments for children who come into conflict with the law, as well as including responsibilities for probation officers to facilitate Family Group Conferences and crime prevention programmes. Assistant probation officers were also introduced into this legislation, and they were often given the responsibility of finding families. Therefore, while there were delays in passing the Child Justice Bill, the probation officers allowed for the principles to be implemented in practice to some extent by the Department of Social Development through the amendments to the probation legislation.

${ }^{159}$ Training of prosecutors and magistrates in the Child Justice Bill was primarily conducted through the Justice Training College.

${ }^{160}$ Interview with Cheryl Frank dated 28 September 2009.

161 Ibid

${ }^{162}$ Interview with Don Pinnock dated 2 March 2011.

163 Ibid

${ }^{164}$ South African weekly independent newspaper
} 
all the papers. I was getting debates going. I was forcing the issue, and suddenly the Child Justice Bill came back into the parliamentary process...my job was to embarrass the government to put it back on. ${ }^{165}$

\section{The government revisits the Child Justice Bill}

While the tenacity of the activists and the media approach helped to sustain the movement to some degree, without the support from relevant government role players, limited progress could be made in passing the legislation. Hope returned when Yunus Carrim was appointed head of the Portfolio Committee for Justice and Constitutional Development. Muntingh explained that Carrim had three fundamental qualities that were of value to the process: "The new chairperson was firstly a communist, secondly an academic and thirdly a sociologist, so I think under his chairmanship, the approach just changed completely". ${ }^{166}$

Carrim's curriculum vitae provides insight into his personal involvement in and understanding of South Africa's youth movement. In the early 1970s he orchestrated antiapartheid protests at a high school and he became chairman of the National Youth Action in Pietermaritzburg in 1971-72. In 1976 he was detained without trial for arranging protests following the Soweto massacre. ${ }^{167}$ Carrim admitted that the Justice sector was not his personal passion, preferring opportunities to enhance local governments and support public enterprises. ${ }^{168}$ However, he heard the concerns of the child justice activists, and decided to bring the Child Justice Bill back on the parliamentary agenda.

We went to the Minister and Deputy Minister and said, 'The Bill has to be unlocked. It's taking too long! It's been near six years I think, and quite frankly, we want it'. You've got to be active I think. And if you are, you get much of what you want, and so the Bill was released. ${ }^{169}$

Carrim was aware of the factors that had brought the Bill to a deadlock in the parliamentary process and felt that it was important to revisit the proposed legislation using a consultative and inclusive process. ${ }^{170}$ The fact that the Alliance had managed to remain committed to the

\footnotetext{
${ }^{165}$ Interview with Don Pinnock dated 2 March 2011.

${ }^{166}$ Interview with Lukas Muntingh dated 1 October 2009.

167 Yunus Carrim MP in the South African Parliament Brief Political CV

${ }^{168}$ Interview with Yunus Carrim dated 19 October 2010.

169 Ibid

${ }^{170}$ Interview with Yunus Carrim dated 19 October 2010.
} 
process helped to mobilise the key role players at the time the Bill was being reconsidered. ${ }^{171}$ While a number of members of civil society were consulted, Skelton, Gallinetti and Daksha Kassan ${ }^{172}$ participated directly in the parliamentary discussions for the redrafting of the Bill after De Lange's substantial changes which had undermined the values, principles and spirit of the original Bill. ${ }^{173}$ Gallinetti recalled:

Suddenly there was this Child Justice Bill back. That was November/December (2007), and the hearings were going to be at the end of January. So we had an Alliance meeting. We brought everyone down and we had a workshop for two days, where we literally went through each and every provision of the Bill and divvied it up. Everyone did what their speciality was, yet we all had an idea of what we wanted in the Bill as a whole. So we had the overarching submission. We got to Parliament all ready to fight, and the new chairperson was just phenomenal. He had this very inclusive approach. ${ }^{174}$

While gathering the views of the members of the Child Justice Alliance, Carrim was also conscious that the Portfolio Committee's primary responsibility was towards the electorate. In the end, it appeared that both civil society and government remained on the same side during the process. ${ }^{175}$ Carrim acknowledged the influence of civil society on the development of the legislation. However, in his view:

We would have arrived at many of those outcomes at any event because we ourselves, many of us, come from a particular tradition. We understand the national democratic struggle in a particular way, and we're very clear that you can't resolve issues of crime, particularly crime committed by children, by being over punitive. It doesn't work. It's not productive.

Notwithstanding the huge crime challenges we have, not least from children themselves. $^{176}$

\footnotetext{
${ }^{171}$ Interview with Dr Ann Skelton dated 28 September 2009.

${ }^{172}$ A member of the Child Justice Alliance driver group based at CLC.

${ }^{173}$ Interview with Dr Ann Skelton dated 28 September 2009; Interview with Cheryl Frank dated 28 September 2009; Interview with Dr Jacqui Gallinetti dated 15 October 2009;

${ }^{174}$ Interview with Dr Jacqui Gallinetti dated 15 October 2009.

${ }^{175}$ Interview with Dr Ann Skelton dated 28 September 2009; Interview with Portfolio Committee for Justice and Constitutional Development researcher for the Child Justice Bill

${ }^{176}$ Interview with Yunus Carrim dated 19 October 2010.
} 
While the public submissions might have presented new knowledge and research to promote the Bill, members from the Portfolio Committee were particularly convinced by their own investigations on how the principles and practice were being implemented at a grassroots level. What they found was that not only were practitioners in the most remote areas familiar with the principles of the Bill, but they were able to speak about them with confidence, and could give evidence of how they put these principles into practice on a daily basis. This included processes for assessment after arrest, writing assessment reports with recommendations and providing opportunities for diversion and restorative justice. Members from the Portfolio Committee were impressed by this first-hand experience, and it helped to persuade them of the possibilities of the provisions in the Bill. ${ }^{177}$ In his report to Parliament on 23 June 2008 on behalf of the Portfolio Committee for Justice and Constitutional Development, Carrim pointed out:

Of course, public anxieties and frustrations about the levels of crime and the perception that the state is failing to curb crime have heightened. These are very understandable feelings and views, and the Committee is entirely empathetic. But the Committee cannot shape legislation on a new sustainable model of child justice with both immediate and long term goals solely on the basis of the emotions of the public, as legitimate as these are and as accountable as Parliament is to the public. The Committee is careful to avoid being populist and 'short-termist' in our approach and it is precisely because of public concerns about crime and the need to ensure the safety and security of the public that the Committee effected changes to the Bill.

\section{The Child Justice Bill becomes law}

On 25 June, 2008, the South African Child Justice Bill was brought to Parliament for a second reading debate. When introduced by the Minister of Justice and Constitutional Development, Brigitte Mabandla, she acknowledged that this was an historic occasion, particularly given her own role in promoting children's rights in South Africa. The creation of the Child Justice Bill required years of complex engineering. It had taken over fourteen years to design this piece of legislation in a way that would satisfy key stakeholders and measure up to desired standards and values.

${ }^{177}$ Presentation by Yunus Carrim at the second reading debate in Parliament on 25 June 2008 
The Bill became law on 11 May 2009, over six years since the first presentation to Parliament. While there may have been some aspects that veered from the details of the original vision, Shapiro-Liu recalls looking back to the three points that she, Michelle Morris and Ann Skelton had drawn up at their first meeting approximately sixteen years before. These aims were to develop a child justice system for the country, to implement programmes which could keep children out of the criminal justice system and make them accountable, and to have an assessment process for children when they entered the criminal justice system. Shapiro-Liu recalled, "We found that piece of paper serviette some years later and they [the original aims] were all in the proposals". ${ }^{178}$

Muntingh believed that the work by various civil society groups on creating "very reasonable, workable alternative to the... situation of prosecuting children (many of them spending very long periods in prison awaiting trial)" is what attracted people to the movement and sustained their interest over a long period of time. ${ }^{179}$

Pinnock acknowledged:

The best part about it is really what it does for kids. I think everybody who worked on it at root really were very certain. We were all angry at how kids were being treated. We were very certain and we kept saying to ourselves: 'we're working for young people at risk - that's what we are working for! They are getting a raw deal and our job is to make sure that they get a better deal'. I think that's what comes out of this child justice process. It is a cause. $^{180}$

South Africa's child justice movement started to gain momentum as a result of concerned individuals who mostly had some involvement in civil society activities. These individuals' exposure to the effects of the apartheid regime on children, especially with regard to children's detention in deplorable conditions, motivated them to seek credible alternatives to the criminal justice system and detention. While South Africa's child justice advocates and policy makers felt proud of the resulting legislation which reflected the values and principles they had fought for, they were aware that there would be a number of challenges to implementation.

\footnotetext{
${ }^{178}$ Interview with Rosemary Shapiro-Liu dated 11 February 2011.

${ }^{179}$ Interview with Lukas Muntingh dated 1 October 2009.

${ }^{180}$ Interview with Don Pinnock dated 2 March 2011.
} 


\section{Comparing the processes of youth justice transformation between New Zealand and South}

\section{Africa}

Warwick (1973:120) posits that when conducting a comparative case study it is important to "choose comparative dimensions that are in principal universal". Warwick's guidance helped to structure the discussion aimed at drawing the comparisons in the process of youth justice transformation drawn from the construction of the historical narratives between South Africa and New Zealand.

\section{Legislative comparisons}

Significant time and distance separated the emergence of New Zealand and South Africa's youth justice systems. However, the resulting legislation demonstrates considerable similarities between the principles underpinning Section 4 of the New Zealand's CYPF Act and South Africa's CJA as illustrated by the table in Appendix 4.

New Zealand's CYPF Act encompassed matters pertaining both to care and protection as well as youth justice. As such, youth justice legislation in New Zealand is subject to the overarching general objects and principles of the CYPF Act. These objects and principles emphasise the importance of promoting children and young persons' wellbeing in the community within the context of their family or family group, and with recognition of their values, culture and beliefs. The principles encourage that "a child's or young person's family, whānau, hap $\bar{u}, i w i$, and family group should participate in the making of decisions affecting that child or young person, and accordingly that, wherever possible, regard should be had to the views of that family, whānau, hapu , iwi, and family group". ${ }^{181}$ A distinct youth justice system that moved away from the traditional welfare approach was incorporated into this piece of legislation. The key provisions for youth justice are primarily found in Part 4 of the CYPF Act. Judge Brown (1992:2) referred to the youth justice provisions as representing an "act within act" where these measures are set out quite separately from care and protection. During a presentation in Sydney in 2003, Judge Becroft noted, "The combination of objects and principles in the Children, Young Persons and Their Families Act 1989 create a unique hybrid model. This model avoids the polarities of a simplistic 'welfare' / 'justice' debate'”. 182

\footnotetext{
${ }^{181}$ Children, Young Persons and their Families Act 1989 Part 1 General Principles -Section 5(a)

${ }^{182}$ As noted in the discussion of youth justice policy design in Chapter 8 .
} 
Acknowledging that the legislation remained complicated despite the working group's attempts to simplify it, ${ }^{183}$ Judge Brown (1992:2) noted that the key youth justice principles in New Zealand helped to anchor practice. These principles acknowledge that children and young people are vulnerable members of society who require appropriate safeguards and protections. They reinforce the notion that the family, whānau, hapu and iwi should be involved in decision-making processes in relation to their children or young persons who offend, as well as in promoting their reintegration. The youth justice principles in the CYPF Act also emphasise that, wherever possible, alternative measures to criminal proceedings should be sought. These included finding solutions to keep children and young people in the community while bearing in mind the need to protect the public, ensuring that any sanctions are proportionate to the offence and reflect "the least restrictive form that is appropriate in the circumstances" 184 and taking age into consideration. Furthermore, the principles call for "due regard to the interests of any victims of that offending", ${ }^{185}$ thereby providing a forum in which victims' grievances could officially be heard and acknowledged, and where outcomes would seek some level of redress for harm caused.

In South Africa, prior to the Child Justice Act (CJA) of 2008 coming into force, provisions for dealing with children in conflict with the law had been scattered through various pieces of legislation. The passing of the CJA as a single and separate piece of legislation gave overarching legitimacy to the principles and processes that had been endorsed by its creators. Unlike the CYPF Act, South Africa's CJA is self-contained and is not a section of another piece of legislation. Nevertheless, the preamble and objects of the Act recognise that it is underpinned by the values and principles of South Africa's Constitution. This means that it took into account the human rights framework that informed the Constitution. ${ }^{186}$ By the time the final versions of these pieces of legislation reached Parliament, the policy makers were able to put forward convincing arguments indicating that empowering communities to take

\footnotetext{
${ }^{183}$ Reiterated by the new Minister of Social Welfare, Jenny Shipley, in the "Government's response to the Report of the Ministerial Review Team" 1992.

${ }^{184}$ Children, Young Persons and their Families Act 1989,Part 4-Youth Justice Principles, Section 208(f)(ii)

${ }^{185}$ Children, Young Persons and their Families Act 1989,Part 4-Youth Justice Principles, Section 208(g)

186 South African Constitutional Principles: The Constitution of South Africa shall provide for the establishment of one sovereign state, a common South African citizenship and a democratic system of government committed to achieving equality between men and women and people of all races. Everyone shall enjoy all universally accepted fundamental rights, freedoms and civil liberties, which shall be provided for and protected by entrenched and justifiable provisions in the Constitution, which shall be drafted after having given due consideration to inter alia the fundamental rights contained in Chapter 3 of this Constitution (which outlines the fundamental rights of all citizens). The Constitution shall prohibit racial, gender and all other forms of discrimination and shall promote racial and gender equality and national unity. The Constitution shall be the supreme law of the land. It shall be binding on all organs of state at all levels of government.
} 
responsibility for the wellbeing and development of children and young people was in society's best interests. As a result, both pieces of legislation received unanimous support from their Parliaments. The sections below highlight key comparisons in the processes of youth justice transformation in both countries as revealed by the in-depth historical narratives in this thesis.

\section{Alarm at abuses against children}

The impetus to change youth justice policy and legislation in both New Zealand and South Africa came from the concern expressed by community activists around the conditions for children in government facilities. Whether in a New Zealand welfare residence or in a South African overcrowded prison, individuals who bore witness to the conditions in these facilities were alarmed at the human rights abuses against these children and were persuaded to take action. There was not only the concern that existing policies did not appear to be working as well as they could, or that new policy ideas were emerging elsewhere that would be worth trying, but that there was proven and evident human rights abuses in the social welfare and youth justice systems that had to be addressed through changes to policy.

In New Zealand, the problem of child abuse in state institutions had mostly been kept hidden to the general public. It was when ACORD conducted its research into the welfare residences that the extent of the problem in these homes became apparent - but ACORD's findings were not limited to exposing the child abuse. It also provided empirical evidence that the existing policies and practices were affecting Māori children significantly more than any other ethnic group, even though proportionately Māori represented less than $15 \%$ of the population. The government took heed of these concerns and initially tried to respond to them by introducing the Maatua Whangai policy to placate some of the concerns. However, as the Māori Advisory Committee found when looking into the Māori perspective of New Zealand's welfare system, the Maatua Whangai policy was not significantly improving conditions for Māori in the New Zealand's welfare system. Amending social welfare policies affecting children soon became an issue of addressing social imbalances in New Zealand. The PuaoTe-Ata-Tu report outlined the systemic racism that ran the depth of welfare policy, which was found to undermine the traditional role of the whanau, hapu and $i w i$ to raise and care for their children. This process gave Māori a voice they had been lacking for generations as successive governments since the signing of the Treaty of Waitangi acted in what they believed to be the Māori community's best interests. Māori families were being judged without being 
questioned, and their children were being separated from them without consideration of the impact this would have on the children and/or their whānau.

In contrast to New Zealand, awareness of children's rights abuses in South Africa was more common and became one of the primary reasons for the international community's condemnation of the apartheid regime. However, the extent and level of abuse, particularly in relation to children being detained without trial during the state of emergency, was kept hidden as much as possible from the public. This was similar to the secrecy around abuses of children in New Zealand's welfare residences, the majority of which were Māori. As in New Zealand, concern around the abuse of children in government facilities and the separation from their families was raised by human rights activists from community groups in South Africa, particularly the Black Sash and DPSC. They eventually became organised into the Free the Children Alliance in order to raise consciousness around this phenomenon.

The circumstances and settings may have been different in these two contexts. However, in both New Zealand and South Africa community activists exposed to children's rights abuses at the hands of the state, particularly against children from the most marginalised groups in society, prompted movements that would fundamentally change policies relating to children in conflict with the law. This illustrates the similarities around the motivation to take action in both countries.

\section{Addressing gaps in policy and legislation}

Both South Africa and New Zealand governments realised that in order to improve existing processes to respond to children in conflict with the law there needed to be significant changes to the legislation. Both countries decided to consolidate provisions for youth in conflict with the law, framed by overarching principles and guidelines related to child justice specifically.

In New Zealand, the government acknowledged that the child welfare legislation from the 1970 's needed to be reviewed. The first discussion paper for the review of children and young person's legislation identified the need to change existing policies as a result of shifting demographics, awareness of children's rights abuses in New Zealand, an acknowledgement that some interventions were disproportionate to children's actions and the over-representation of Māori in the system (Review of Children and Young Persons Legislation-Public Discussion Paper, 1984). A key concern was that the existing legislation 
was not doing enough to keep youth out of the justice system. The government acknowledged that a number of children being remanded in custody awaiting court hearings were eventually granted community-based outcomes, indicating that detention in custody was not necessary in the first instance. The Review of Children and Young Persons Legislation (1984:37) noted that: "Too many children and young people are being arrested and brought into the official system for relatively minor offences".

In South Africa, while community activists were aware of the major problems affecting children, particularly black children in custody, the real opportunity to revisit policy and legislation came with the ANC government at the end of apartheid in 1994. The political will to address this problem was embedded in South Africa's first democratic Constitution. This cause also appealed to the members of the new government, who were conscious of the extent to which child justice symbolised the struggle against apartheid. As such, the government supported law reform to ensure fair treatment of these children. A problem for South Africa when reviewing youth justice legislation was that existing laws were scattered through a number of pieces of legislation. Hence, a key purpose of the youth justice law reform in South Africa was to develop one piece of legislation which would provide procedural guidance when dealing with children in conflict with the law.

\section{Working through ideological tensions}

The political will to review existing youth justice policies and legislation was evident in both South Africa and New Zealand. However, both countries experienced ideological tensions between different groups which stymied the law reform process. While there was agreement about the problems affecting children in conflict with the law and with the shortcomings of existing policy and practice, differences emerged in relation to the most appropriate response.

In New Zealand, the initial policy review and draft legislation placed emphasis on the use of teams of professionals as primary decision makers in determining outcomes for children and young people. As a result, this proposed approach would effectively have side lined families from decision-making about their children on the basis that families lacked the knowledge, insight and skills needed to address their children's needs. Many supporters of this professional approach had such limited faith in families and communities that they believed giving families more of a voice and a role would be damaging to children. They came to this conclusion with little consultation with families or communities. The decision to set up a Māori Advisory Committee to consult with Māori families and communities on their 
experience of the social welfare system around the same time as the initial review of the Children and Young Persons Act of 1974 was not initially intended to contribute to the law reform process. However, the powerful and unrelenting voice from the Māori community during and after the consultation rounds made it clear that their desire to take primary responsibility in relation to their children in line with their customs and traditions could not be ignored. As a result, the draft Children and Young Persons Bill of 1984 which proposed a professional response to children in the welfare system and in conflict with the law came to a grinding halt. The incoming government acknowledged that opposition to the Bill was causing too much agitation and would need further review before it could proceed any further. This decision resulted in a new round of community consultations and a legislative design that better reflected the expressed interests of the community in relation to their children and young people's wellbeing. In turn, this informed the design of the FGC aimed at empowering families and placing them at the centre of the decision-making process around children and young people in the welfare and youth justice system.

As in New Zealand, South Africa's legislative process faced significant delays as a result of an ideological tension between the community interest groups and the government Portfolio Committee responsible for advancing the legislation. However, in South Africa, this happened somewhat in reverse to New Zealand's experience. The idea of splitting child justice into a 'two pronged' approach was at odds with the underlying philosophy of the Child Justice Bill and was unacceptable to the policy makers and community interest groups, mostly represented by the Child Justice Alliance. While law and policy makers and community interest groups were willing to negotiate around some of the procedural details, they made it clear to the government that they were not willing to compromise on the principals underpinning the draft legislation. Following the changes proposed by De Lange's Portfolio Committee the Bill was shelved and it took some years before it would proceed again.

In constructing the framework for the new youth justice systems, both New Zealand and South African law and policy makers set a solid foundation based on a core set of values and principles. These values and principles were cemented by support from the community, represented by community interest groups. Proposals which veered from these core principles were rejected by community interest groups particularly if they risked destabilising the foundation which underscored the importance of involving families and communities in the reintegration and development of children and young people. This principle was central to the 
objective of improving the lives of children, youth and their families, which in turn would contribute to building safer communities.

\section{The political will of key government officials facilitated the changes}

Blockages in the process of advancing youth justice reforms in both countries were largely freed up by key government officials who possessed a set of personal values that aligned with the idea of using a more inclusive, community-based approach to dealing with children in conflict with the law. In New Zealand, Cullen's appointment to the position of Minister of Social Welfare was instrumental in considering how to incorporate the strong request from Māori whānau, hapū and iwi to be responsible for decision-making around their children's wellbeing. Minister Cullen believed in seeking ways to restore social imbalances, and was therefore receptive to an approach which would empower disadvantaged communities. His support for these values and principles played an important role in advancing the youth justice system which was different to anything that had existed before, either in New Zealand or elsewhere.

Minister Carrim's appointment as Chairperson of the Justice and Constitutional Development Portfolio Committee in South Africa is believed to be cornerstone to bringing youth justice back on the government's agenda in South Africa, after approximately five years of stalemate. As with Minister Cullen, Minister Carrim's personal experiences which shaped his values contributed to his support for the version of the child justice legislation proposed by SALRC and promoted by the Child Justice Alliance. As such, he played an important role in ensuring that the draft legislation was revised after it had been altered by the former Portfolio Committee under De Lange.

Minister Cullen in New Zealand and Minister Carrim in South Africa's support for a youth justice system that gave importance to families and communities and favoured restorative, community-based outcomes over criminal justice procedures and detention for children in conflict with the law proved to be invaluable in embedding these principles as part of a credible approach to youth justice in both countries.

\section{Comprehensive recasting of legislation to ensure it met the intended values and principles}

Once the decision was made to review the Children and Young Persons Bill of 1984, the policy makers realised that a thorough review process was needed if it was going to be drafted in a way that reflected the interests of the community following the consultations. 
Given there was going to be a fundamental shift in the approach to care and protection and youth justice, the draft Bill needed to be overhauled. The advantage was that there was already a law reform process underway which could be capitalised on rather than starting from scratch, even if most of the content of the draft legislation needed to be rewritten.

Similarly, in South Africa, by the time Carrim agreed to review the Child Justice Bill, there was an existing law reform process that could be tapped into. Much of South Africa's child justice review process under Carrim involved undoing De Lange's changes to the original draft to realign it with the values and principles of the Child Justice Bill of 2002. Skelton recalled: "It was the destroyed Bill that needed to be reworked. We did try and argue to bring back the other one, but we couldn't really because this is where it had gotten to". ${ }^{187}$ As a result, much of the review process involved making the new legislation resemble the original version as much as possible.

\section{Consultation}

In considering how to address the needs of children in conflict with the law, policy makers in both South Africa and New Zealand undertook extensive processes of consultation. In New Zealand, it quickly became evident to incoming Minister Cullen that not including the recommendations from the Puao-Te-Ata-Tu report was a significant oversight in the proposed legislation that needed to be dealt with. While the Māori Advisory Committee had already consulted widely with community, Minister Cullen wanted to gather views of the community with the purpose of using their perspectives to shape the new legislation. As a result, government officials undertook a new round of community consultations, seeking experiences from families affected by the existing welfare policies, as well as community leaders, workers and activists familiar with the impact of these policies on Māori and Pacific Island communities in particular.

While there was extensive consultation with key role players from the government, nongovernment and academic sector in the development of the CJA in South Africa, a significant difference to the New Zealand process was that there was not the same level of direct grassroots level community consultation in South Africa to inform the process. Instead, South Africa relied more strongly on existing theoretical frameworks (particularly restorative justice), international standards for children's rights and youth justice, and experiences of

${ }^{187}$ Interview with Dr Ann Skelton dated 28 September 2009. 
individuals exposed to children's rights abuses in the existing youth justice system. The bulk of the initial consultation by the SALRC occurred through a process of workshops with key groups and individuals with experience in children's rights in particular, resulting in an Issue Paper (Issue Paper 9) (SALRC, 1997) identifying key themes. South Africans also consulted with international experts in the fields of restorative justice, children's rights and child justice for advice and guidance on how to shape their new child justice system.

Shapiro-Liu noted:

In South Africa it was very much driven by people who were not affected by [youth justice experiences]personally, these were academics, advocates, workers, 'lefties' who were in a 'white kabala' to begin with. But from what we had seen, we had the capacity to do stuff. It was a children's rights agenda, and we were very clear about that. I don't think there was a community consultation process, and I don't think it was essential. There was lots of community involvement, because the programmes were in the community. ${ }^{188}$

Pinnock explained that the type of relevant experiences the key players had been involved in, even if they were not directly from the community, helped to provide insights in to what would be needed: "All of us working there were part of the $\mathrm{UDF}^{189}$; were in the townships; were under fire at some time or (the other ) [sic] another". ${ }^{190}$

In his closing remarks to parliament when presenting the Child Justice Bill for its second reading on 25 June 2008, Carrim noted that he hoped that the time lapse between the first and second presentation to the Portfolio Committee enabled greater consultation with key interest groups in order to contribute to a superior version of the legislation:

We would like to think the delay served to ultimately produce a better quality Bill. Certainly, the Bill is the outcome of considerable negotiations among a range of stakeholders, and there is now substantial consensus on its content between Parliament, the Executive, NGO's, academics and other experts.

\footnotetext{
${ }^{188}$ Interview with Rosemary Shapiro-Liu dated 11 February 2011.

${ }^{189}$ The United Democratic Front a former South African opposition force which united a variety of resistance groups during apartheid.

${ }^{190}$ Interview with Don Pinnock dated 2 March 2011.
} 
In both New Zealand and South Africa, youth justice transformation occurred at a time of broader social changes, particularly with respect to addressing harmful historical racial imbalances. Overarching experiences of social uprising by disadvantaged indigenous social groups had an influence on the design of youth justice policy and legislation in both countries. These processes included seeking reparation for previous damages through the effects of colonisation and an acceptance of indigenous cultural practices - both important underlying principles in the resulting pieces of youth justice legislation in both countries. Against this backdrop, it was important for policy makers to also consider creating a youth justice system that was flexible enough to accommodate a range of cultures as well as personal circumstances of offenders, victims and families.

\section{Piloting projects to find credible solutions}

During the transformation periods in both South Africa and New Zealand, where new ideologies were shaping youth justice policy, pilot projects initiated both formally and informally helped to provide practical options and give credibility to the ideas being proposed. In New Zealand, Judge Mick Brown and Judge David Carruthers took advantage of their positions to demonstrate the possibilities of turning the principles into practice. They believed in the strength of families and communities to make the best decisions for their children and young people both in terms of consequences for their actions as well as preventing further offending through supporting their development and reintegration through processes of holding their children to account. Therefore, in their capacity, they sought to involve communities and families as much as possible in processes involving their children and young people in conflict with the law. While these community pilot projects were essentially ad hoc initiatives, they helped with the process of developing credible alternatives to existing youth justice processes which were proving ineffective. These pilot projects supported the vision being moulded by policy makers in New Zealand in the late 1980s based primarily on concepts of family empowerment and support, responsibility, restoration and reintegration into an innovation aimed at addressing the needs of all parties; the youth justice FGC.

In South Africa, youth justice lawyers and policy makers as well as NGOs such as NICRO played a significant role in trying out strategies that would put principles into practice. In the beginning, these activities were focused on keeping children out of the criminal justice system in order to prevent children from being detained or tortured. These were small scale 
local diversion initiatives which required support from the judiciary and prosecutors. For the most part these initiatives involved administering an assessment to consider whether alternatives to detention were possible, followed by a recommendation for a diversion programmes if viable. Diversion programmes largely provided basic life-skills designed to help children gain insight into the impact of their offending behaviour and to prevent further offending. In addition to providing a life-skills diversion programme, NICRO in particular started experimenting with other strategies for children using restorative justice concepts, such as trialling victim-offender mediations. Again, opportunities were limited and depended on the willingness of magistrates and prosecutors to trial these options. Later the IMC pilot projects helped to breathe life into the proposed child justice principles. By the time South Africa was seeking to pass the Child Justice Bill for a second time, the proposed practice had already taken root and was spreading to many parts of the country, in spite of the lack of a substantial legal framework to guide the practice. Frank noted:

Generally the principles were accepted a long time before the Act came into operation. The long lag time really helped in cementing the ideas. So what we were saying to the Portfolio Committee was that a lot of this is happening already - you're just putting it into legislation. It's not like other legislation that you've got to make happen. A lot of it is already in the heads of practitioners. ${ }^{191}$

While both New Zealand and South African policy makers were committed to advancing a youth justice design based on a specific set of values and principles, they needed to be able to demonstrate how these principles could be applied in practice in order to convince the government and the public of their proposed approach. Piloting initiatives as part of the process increased the credibility of what was being proposed, particularly with regard to diversion options and ways to involve the community in supporting children's reintegration. This helped to translate overarching principles into legal procedures that could be implemented widely.

\section{Conclusion}

This chapter has provided socio-historical accounts of youth justice transformation in New Zealand and South Africa, largely as constructed from the interviews with the participants.

${ }^{191}$ Interview with Cheryl Frank dated 28 September 2009. 
The key areas of comparison between these two countries' experiences of youth justice transformation highlight how these processes were part of a greater social need to empower disadvantaged and marginalised communities in both countries and to address the effects of previous policies on indigenous children, young people and their families. It further demonstrates how political will and timing plays a critical part in advancing the policy agenda of motivated community members and policy makers. While both countries were eventually successful in overhauling their youth justice systems, once the legislative frameworks were in place, the next challenge was to develop operational strategies which could bring these systems to life. 


\section{Chapter 6}

\section{Implementation}

When designing the new youth justice systems in New Zealand and South Africa, the key role players were committed to a shared set of values and principles that underpinned their vision and common goal. While successfully passing the legislation in both countries provided a clear philosophical guide for youth justice practice in both countries, mechanisms needed to be developed that would turn strategic policy into practice. This chapter looks at how the new youth justice systems were implemented in both countries, and identifies the challenges both countries have faced in trying to sustain the youth justice vision over time in practice.

\section{Implementing agencies}

While the new approach to youth justice in New Zealand and South Africa placed importance on giving families and communities an increased role in decision-making about children and young people, various government agencies were responsible for implementing the new youth justice systems. These relevant government agencies and their roles in both countries are discussed below.

\section{New Zealand}

\section{Police}

The CYPF Act identifies the New Zealand police as the gatekeepers of the youth justice system, holding them primarily responsible for ensuring that the majority of youth offenders are kept out of Youth Courts. New Zealand's police youth aid section was empowered to divert children and young people from the criminal justice system. The law provided for all minor offences to be dealt with by police with a warning. For slightly more serious offending, youth aid officers could administer a range of diversionary type processes (referred to as alternative actions) aimed at addressing the child or young person's offending behaviour while still keeping them out of court. These alternative actions include community work, written apologies to the victim or imposing curfews for example.

The role of police in the new CYPF Act received criticism from certain sectors soon after the legislation came into force, particularly frontline police who were used to operating in a 
different way. ${ }^{192}$ It required police to devolve much of their control to families and communities. Maxwell explained some of the resistance from some sectors of the New Zealand Police to the new model:

There was enormous scepticism here when [the CYPF Act] was introduced. Police ran an active campaign because they weren't consulted. It really got their backs up, and they sent someone touring around the country telling people why they should oppose it because it wasn't going to work, before it had even started. That made life very difficult to begin with. ${ }^{193}$

John Angus recalled:

First they (police) didn't like all the procedures, because they got in the way of some of the things they had been doing quite normally with young people, like loading lots of offences onto them and getting lots of confessions, questioning them without adults being present - just putting the pressure on them. Suddenly they were in this very complicated regime, when most frontline police in my experience see that enforcement and sanctions are sort of the first, second and third priority, and everything else is people getting slapped on the wrist with a wet bus ticket...The youth aid people, who had always been part of the police had to win a lot of legitimacy and respect from their peers at the police. They were a really important part of responding to offending by young people. ${ }^{194}$

The perseverance of New Zealand's youth aid officers coupled with their proven understanding of children and young people resulted in a growing respect for them from the community. The ongoing benefits of their role, especially in terms of promoting diversion, reintegration and restoration, ${ }^{195}$ have been demonstrated over time. Judge Becroft, a young lawyer at the time New Zealand's youth justice legislation passed, has since become the Principal Youth Court Judge. He believes the success of the youth aid division has been one of the most important and least celebrated contributions to New Zealand's youth justice system:

\footnotetext{
${ }^{192}$ Interview with John Angus dated 8 December 2009.

${ }^{193}$ Interview with Dr Gabrielle Maxwell dated 29 March 2010.

${ }^{194}$ Interview with John Angus dated 8 December 2009.

${ }^{195}$ Ibid
} 
I think what makes them so effective is that they give genuine substance to the legislative philosophy...I think they attract some of the brightest and most motivated police officers in the country. Not only does the country not understand how good they are, but their own police force doesn't understand. They sometimes were seen as 'namby-pamby', 'kumbaya', 'milo-drinking' social workers who ought to be wearing roman sandals not pepper spray and boots. So that's why I think they are so good. They really take the legislation seriously, know it inside out and deliver on it, highly trained and very capable. ${ }^{196}$

\section{Social Development}

In New Zealand, the Ministry of Social Development (formerly known as the Department of Social Welfare at the time the CYPF Act passed) created a new 'business unit' initially called the Children and Young Person's unit in 1992. In 1995 this was renamed the Children, Young Persons and their Families Services. Eventually in 2006, this service became part of the Ministry of Social Development, now known as Child, Youth and Family (CYF). The 'purpose built' CYF branch had an important role in the implementation of youth justice processes, particularly with regard to FGCs. Under the CYPF Act, new positions of youth justice coordinators was created for setting up and facilitating FGC processes, and youth justice social workers to monitor outcomes of FGC plans and other requirements from the Youth Court. ${ }^{197} \mathrm{CYF}$ social workers were made responsible for supervising any children ordered by the court to supervision ${ }^{198}$ including supervision with activities. ${ }^{199}$

\section{The FGC process in New Zealand}

There are two types of Youth Justice FGCs in New Zealand. One is the Intention to Charge (ITC) FGC and the other is a court ordered FGC. ITC FGCs are held as an alternative to court processes when a young person admits to the offending. They allow for FGC plans to be formulated and implemented without any charges being laid (particularly if the plan is successfully completed). Usually, the primary trigger for an ITC FGC is when the police youth aid officer decides that the matter requires a higher level of intervention than can be

\footnotetext{
${ }^{196}$ Interview with Judge Becroft dated 24 November 2009.

${ }^{197}$ Section 18(3) of the Children, Young Persons and their Families Act 1989

${ }^{198}$ Section 304 of the Children, Young Persons and their Families Act 1989. The social workers' responsibilities while supervising the young person are outlined in Section 305 of the same Act.

199 Section 307 of the Children, Young Persons and their Families Act 1989
} 
provided by any alternative action options at their disposal. The police youth aid officer therefore refers the matter to a Child Youth and Family (CYF) youth justice coordinator, who is then responsible for convening the FGC. This includes preparing the FGC by making contact with the young person, their family and victims. It allows them to explain the FGC process to all parties, answer any of their questions and to encourage them to consider any additional support people to attend and assist. All parties are told to think about what they want to say prior to the conference, and what they believe would help to make amends for the offending. With the input of the child or young person's family and the victim, FGC coordinators set up a time and date for all parties to meet for the FGC. Court ordered FGCs are initiated for matters where charges have been laid. This can be directly by the police following an apprehension or if an ITC FGC plan has failed, such as the young person denies the offending and chooses to have the matter heard in court.

CYF youth justice coordinator will generally facilitate the FGC (although in some cases a cofacilitator - not necessarily from CYF - may assist, with the agreement of the participants). FGC facilitators are responsible for guiding and overseeing the process, and ensuring that all relevant parties have their say. Also present at the conference is a police youth aid officer, the young person with their support (usually at least one parent, but this can include a range of support people from the extended family and the community, and their lawyer). Some children and young people may have representatives from Health or Education or a programme provider present, although they require consent from the participants as they are not automatically entitled members under the CYPF Act. Wherever possible, victims are present with their support people. The number of support people from family and the community on both sides usually depends on who the key participants have selected to attend.

The process begins with the FGC coordinator opening the conference and introductions. This is followed by the youth aid officer reading out the summary of facts of the offending and the youth offender admitting to the charges. Thereafter, the forum is opened to victims and their support people to express the impact of the offending. The young person is then given a chance to explain the circumstances around the offending (Daly, 2001:66). After discussing the offending, the young person and their support people are taken aside by the FGC coordinator to discuss what steps they can take to make amends for the offending. These outcomes can include a range of options usually including a written apology, community work and/or some form of financial compensation (Daly 2001:67). However, responses can 
be more creative and holistic, including elements which can directly make amends for any harm. This can include for example, young people personally repairing any damage to property, or providing a service to the victim to help make life easier or more enjoyable. Young people may also be required to attend counselling or programmes to address the factors that contributed to their offending, such as violence prevention programmes or drug and alcohol counselling. They may also attend courses that to help them to desist from further offending.

The young person and their family propose their plan to the victim, who is given the opportunity to comment on the plan and on whether it will address the offending in the victim's view. Following this negotiation, a final plan is agreed on, and timeframes are set for completing the required activities. Once an FGC is agreed on by the key parties, a CYF youth justice social worker is responsible for supporting the young person and their family to implement the plan.

While youth justice matters are treated separately to care and protection, the Youth Justice Section of the CYPF Act also provides for the needs of children and young people in need of care and protection. CYF social workers are required to intervene where issues pertaining to care and protection are identified when dealing with children and young people in conflict with the law. ${ }^{200}$ In these matters, children and young people would be subject to care and protection procedures in addition to the youth justice processes.

\section{Courts}

The Youth Court in New Zealand was an innovation of the CYPF Act set up for dealing with matters specific to youth justice. In principle, children and young people should only appear before the Youth Court in the most serious cases. The Youth Court jurisdiction primarily deals with matters pertaining to young people aged between 14 and 17 years of age. Until recently, children between the ages of $10-13$ could only have criminal proceedings against them in cases of murder and manslaughter. ${ }^{201}$ In such cases, the first hearing must be held in the Youth Court. In 2010, the New Zealand Government passed The Children, Young Persons and their Families (Youth Courts Jurisdiction and Orders) Amendment Act of 2010.

\footnotetext{
${ }^{200}$ If a Youth Justice FGC is convened which then makes recommendations and plans relating to care and protection, then that FGC is considered to have been convened under Part II of the Children, Young Persons and their Families Act 1989 which deals specifically with care and protection matters. Section 280 of the Act also allows the Youth Court to make a recommendation for the young person to be referred to care and protection services.

${ }^{201}$ Section 272 of the Children Young Persons and their Families Act 1989
} 
This amendment extended the range of sentences 12 and 13 year olds before the Youth Court can appear on, beyond murder and manslaughter, and for charges that carry a maximum penalty of imprisonment of fourteen years or more.

The Youth Court has a number of court orders at its disposal which it may impose "where a charge against a young person is proved before a Youth Court". ${ }^{202}$ These include a discharge, fines, reparation, forfeiture of property, supervision (which can either be with residence or with activities) or community work. ${ }^{203}$ The most severe order at the Youth Court's disposition is to convict the young person in the Youth Court and then transfer him/her over to the District Court for sentencing, where they are subject to the sentencing provisions under New Zealand's Sentencing Act (2002). This, however, only applies to young people of 15 years and older. ${ }^{204}$ In such cases, young people may be sentenced to the range of sentences available to the District Court under New Zealand's Sentencing Act 2002 including various forms of detention, i.e. imprisonment, home detention and community detention. ${ }^{205}$ The Youth Court has the authority to request the holding of an FGC at any time during the proceedings if it believes this will assist the decision-making process. ${ }^{206}$ It also has the power to discharge any information laid against a young person after looking into the matter (unless it is a purely indictable offence $)^{207}$, in which case it will be "deemed never to have been laid". 208

Whether a young person admits to the offending or the offending is proven in court, s/he will be referred to CYF for an FGC. The CYPF Act makes it clear that the Youth Court must take into account the recommendations of an FGC, ${ }^{209}$ and that it cannot impose any court orders without an FGC being held. ${ }^{210}$ If there is a need for any further appearance on a matter

\footnotetext{
${ }^{202}$ Section 283 of the Children, Young Persons and their Families Act 1989

203 Ibid

${ }^{204}$ Section 283 of the Children, Young Persons and their Families Act 1989 The Sentencing Act 2002 replaced the former Criminal Justice Act 1985 resulting in these amendments to the Children, Young Persons and their Families Act 1989.

${ }^{205}$ Home Detention and Community Detention became sentencing options for youth when they became introduced as sentencing options to the Sentencing Act 2002 in October 2007. Home Detention includes full time monitoring including electronic monitoring. Community Detention restricts the young person to their residence during specified times of the day. Young people may only be transferred to a District Court where charges are purely indictable or "the nature and circumstances of the offence are such that if the young person were an adult and had been convicted of the offence in a Court other than a Youth Court, a sentence of Imprisonment...or a sentence of Home Detention...would be required to be imposed on the young person".

${ }^{206}$ Section 281B of the Children, Young Persons and their Families Act 1989

207 A case that must be heard by jury trial

${ }^{208}$ Section 282 of the Children, Young Persons and their Families Act 1989

${ }^{209}$ Section 279 of the Children, Young Persons and their Families Act 1989

${ }^{210}$ Section 281 of the Children, Young Persons and their Families Act 1989
} 
following an initial court outcome, the court may not make any amendments to the initial decision until a new FGC has been convened. ${ }^{211}$ If the FGC plan is completed by the young person, the matter is taken back to court where the matter will often be discharged resulting in no criminal record. Where FGC plans are not completed, and little or no effort is made by the young person to fulfil their obligations, the court may deal with the matter through court orders, such as Supervision with Activity or Supervision with Residence (whereby the child or young person is required to spend part of their order in a youth justice residence run by Child, Youth and Family). In more serious cases, youth court judges may decide to transfer the matter to the District Court or High Court for sentencing where the child or young person can be sentenced under the adult jurisdiction and subject to the sentences available in New Zealand's Sentencing Act of 2002.

\section{South Africa}

Police

The SALRC considered whether it would be feasible for South Africa to apply a similar approach to New Zealand in terms of using police as the primary decision makers and gatekeepers to the youth justice system, including being responsible for running the majority of alternative actions to divert children from the criminal justice system. The Commission concluded that it was too soon for South African police to take on these types of roles and responsibilities given the relatively recent history of police brutality towards children in conflict with the law. Skelton noted that South African police themselves were reluctant to be responsible for such decision-making, as this "could be open to blackmail and people could come and pressurise them to withdraw cases". ${ }^{212}$ Therefore it was agreed that the decision on whether to divert or prosecute a youth justice matter would remain with the state prosecutors. Nevertheless, the new legislation still made changes to police's responsibilities to children in conflict with the law which required South African police to adjust their approach. Police are required to inform a probation officer of an arrest within 24 hours ${ }^{213}$ as well as to assist in locating the child's parent, guardian or appropriate adult (Gallinetti, 2009:36). Police are also required to follow correct referral processes depending on the child's age and the nature of their offending.

\footnotetext{
${ }^{211}$ Section 281 of the Children, Young Persons and their Families Act 1989

${ }^{212}$ Interview with Dr Ann Skelton dated 28 September 2009.

${ }^{213}$ Section 18(4)(a) of the Child Justice Act 2008.
} 
Pinnock describes some of the difficulties police have had in understanding their role since the legislation was implemented in South Africa in an article published in the 'Mail and Guardian' dated 30 September 2011. This includes police being confused by the provisions in the legislation, and therefore not following through on procedures correctly. This undermined the system and children's ability to receive appropriate interventions to address their offending behaviour. ${ }^{214}$ Much of this confusion and uncertainty by South African police is attributable to their lack of training in the provisions of the CJA. As no specialist division to deal with children in conflict with the law existed, all South African police were required to be cognisant of their responsibilities towards children under the Act. However, according to Badenhorst (2011:15), by the time the Act came into force in April 2010, only 5\% of the police force had received adequate training in the Act.

\section{Social Development}

In South Africa the law makers had to determine who would be responsible for the coordination of processes for children in conflict with the law. The SALRC believed that the creating a new 'youth justice coordinator' role like in New Zealand was probably not possible for South Africa as its general human resource capacity was limited. It was eventually agreed that this responsibility should lie with the South African Department of Social Development (DSD) and that the existing probation officers' role would be best suited to implementing a number of key provisions in the Bill. ${ }^{215}$ Probation officers had been responsible for supervising child offenders in the community for almost a century, and this position was capitalised on when the IMC began piloting community-based initiatives for children in conflict with the law in 1995 (Skelton and Tshehla, 2008:37).

Similarly to New Zealand, South Africa transformed the Department of Social Welfare to the Department of Social Development in 2002. Graser ${ }^{216}$ explained that the purpose of this change was to accommodate a wider range of social development activities linked to the process of nation building. The intention was to introduce a number of 'social service professions' including probation. Under the new umbrella of the DSD, the probation officers role expanded to include a number of additional tasks, many of which were in line with developments taking place in child justice policy prior to the CJA coming into force. This

\footnotetext{
${ }^{214}$ These comments in Don Pinnock's article also refer to observations made by Ann Skelton and James Albanie, the programme manager for the social crime prevention programme for the Department of Social Development in the Western Cape.

${ }^{215}$ Interview with Dr Ann Skelton dated 28 September 2009.

${ }^{216}$ Interview with Dr Roland Graser dated 5 May 2012.
} 
was reflected in the amendments made to the Probation Services Act in 2002 which aligned the role of probation officers with processes for child justice transformation taking place in South Africa. These amendments comprised the first legal provisions for probation officers to run FGCs and 'restorative justice as part of appropriate sentencing and diversion options' ${ }^{217}$ This legislation also introduced mandatory developmental assessments by probation officers for children in conflict with the law, and allowed for the appointment of assistant probation officers to help probation officers administer the range of community-based activities, including family finding. Adding these provisions to the Probation Officers Amendment Act in 2002 enabled some of the child justice approaches proposed in the Child Justice Bill to be implemented during the period awaiting the introduction of the new substantial legislation.

FGCs were not given the same weight in South Africa's child justice legislation that had been envisioned during the early proposals soon after Maxwell's visit to South Africa. ${ }^{218}$ Skelton explained that while the SALRC wanted to include FGCs in the child justice system, it felt that it was unrealistic to place the FGCs at the centre of the process in South Africa as it was in New Zealand: 219

We didn't really think we could completely replace our court system with sort of FGC as the centre piece (which is of course what Gay [Gabrielle] Maxwell would have suggested we should do and that we should stop thinking inside this box). We compromised on that and ended up saying that the FGC should be a diversion programme or part of the sentencing process, but it would be a referral from the court. ${ }^{220}$

According to the CJA, FGCs, VOMs or "any other restorative justice process which is in accordance with the definition ${ }^{221}$ of restorative justice" 222 can influence sentencing. These sentences are referred to as 'restorative justice sentences'. The Child Justice Court may "confirm, amend or substitute" any of the recommendations made as part of the restorative

\footnotetext{
${ }^{217}$ Amendment of Section 3 of the Probation Services Act 116 of 1991

${ }^{218}$ Interview with Lukas Muntingh dated 1 October 2009

${ }^{219}$ As described in the article written by Skelton, Shapiro-Liu and Pinnock entitled "Drafting New Juvenile Justice Legislation for South Africa-Keeping Children Where They Belong”.

${ }^{220}$ Interview with Dr Ann Skelton dated 29 September 2009.

${ }^{221}$ The definition of 'restorative justice' according to the Child Justice Act 2008 is "an approach to justice that aims to involve the child offender, the victim, the families concerned and community members to collectively identify and address harms, needs and obligations through accepting responsibility, making restitution, taking measures to prevent a recurrence of the incident and promoting reconciliation".

${ }^{222}$ Section 73(1)(c) of the Child Justice Act 2008.
} 
justice plan. If the Child Justice Court does not agree with the plan, it can impose any other sentence allowed by the CJA.

\section{$\underline{\text { Assessment and Preliminary Inquiries in South Africa }}$}

Instead of FGCs, the assessment and preliminary inquiries of children in conflict with the law were considered central processes in the CJA. According to the CJA, the pre-trial assessment must be carried out by a probation officer within 48 hours of arrest in preparation for preliminary inquiry (this is described in more detail below).

The key purposes of the pre-trial assessment are to establish the child's age and criminal capacity, to determine whether the child is in need of care and protection, to ascertain whether a child can be released to a parent or guardian and if not what placement options would be most suitable and available and to determine whether the child can be diverted (which includes whether the child accepts responsibility for his/her actions). All aspects of the assessment must be carried out in the best interests of the child. This can mean excluding a parent or guardian if it is deemed that their presence is disruptive or undermines the process (Gallinetti, 2009:34).

The CJA requires the assessment to use a developmental, strength-based approach. This approach was piloted and recommended by the IMC and had already been incorporated into South Africa's Probation Officers Amendment Act of 2002. South African social workers for children turned to Brendtro and Larson's developmental theory referred to as the 'Circle of Courage'. This model gained popularity in assessment processes aimed at what they refer to as 'reclaiming youth at risk'. This theory combined Native American traditions and contemporary research findings on positive youth development, to identify four central values fundamental to youth development: mastery, independence, belonging and generosity. These values are believed to be interconnected; if one area is lacking, the other areas could suffer as a result. This assessment therefore helps to determine where there are developmental gaps which may be contributing to offending behaviour and what measures can be put in place to address these gaps, thereby promoting children's pro-social development and reintegration.

While the Circle of Courage has not been an assessment model utilised in New Zealand, New Zealand also has an assessment model which draws in indigenous principles, called Te Whare Tapa Wha. This was initially developed as a health model in the early 1980s by Mason Durie, who compared the principles of health and wellbeing to a marae whare. It demonstrates how 
a person's wellbeing is the integrated functioning of physical (Te taha tinana), psychological (Te taha hinengaro), spiritual (Te taha wairua) and family (Te taha whänau) health. If there is a deficit in any of these areas, then other parts of the 'whare' or person will be affected, and therefore their overall wellbeing. As with the Circle of Courage model, in order to enhance a person's wellbeing it is important to address the areas of deficit to bring the person back in balance.

Gallinetti considered the assessment a significant part of the process which had evolved significantly during the child justice transformation process. ${ }^{223}$ Thulane Gxubane is a former social worker at a secure care facility who trains probation officers in their responsibilities under the CJA at the University of Cape Town. He explained the importance of the developmental assessment as follows:

You've got to be very careful what you decide. Your decision must be informed by the full picture. Sometimes you may never get a full picture in reality, but at least you would try as much as you can before you decide...Saying: 'What is in the long term interest of this person?', 'What are the strengths of this person?', 'What can we do to make sure this person doesn't have to go to Duyambu ${ }^{224}$ (or whatever)' and finding somebody who this person can relate to. So it's a whole way of looking at this process ... having a long term vision about this person. ${ }^{225}$

South African policy makers developed the 'preliminary inquiry' as the mechanism for first deciding what should happen to a child entering the child justice system. ${ }^{226}$ The idea of the preliminary inquiry was proposed early on in the planning of the child justice process. It was designed to provide a way for key role players, including the child, the child's parent(s) (or an appropriate adult or guardian) the probation officer, the magistrate, the prosecutor, to pause to consider the child's circumstances and the possibilities for diversion. ${ }^{227}$ This process should be assisted by a probation officer's assessment report outlining the child's circumstances. This forum is also intended to help determine whether the child should be referred to the Children's Court if deemed "in need of care and protection" (Gallinetti, 2009:39). If this is the case, the child is referred to a social worker to proceed with the

\footnotetext{
${ }^{223}$ Interview with Dr Jacqui Gallinetti dated 15 October 2009.

${ }^{224}$ A secure care facility for children awaiting trial in Johannesburg

${ }^{225}$ Interview with Thulane Gxubane dated 13 October 2009.

${ }^{226}$ Part 1 of Chapter 7 in the Child Justice Act 2008

${ }^{227}$ Interview with Dr Ann Skelton dated 28 September 2009.
} 
requirements under the care and protections provisions in the Children's Act of 2005 (similarly to the provisions for children and young people in need of care and protection in New Zealand's youth justice system - although South Africa's processes for determining what to do with a child in need of care and protection are quite different to New Zealand's. This discussion is outside of the scope of this thesis).

The preliminary inquiry itself is meant to be held in an informal manner for the purposes of information gathering about the needs and circumstances of the child. ${ }^{228}$ It is intended to encourage the participation of the child as well as his/her parents/guardian or an appropriate adult (Gallinetti, 2009:39). The original Child Justice Bill of 2002 proposed that all children attend a preliminary inquiry. However, the Parliamentary process altered this to allow for children charged with minor offences (as defined under the Schedule 1 offences in the legislation) be referred directly to a prosecutor to be considered for diversion without having to go through a preliminary inquiry. ${ }^{229}$ However, if the prosecutor does not divert the child, then the child will be referred to a preliminary inquiry to explore the circumstances further to consider diversion. ${ }^{230}$ Skelton believed this parliamentary decision was a practical improvement to the legislation as a number of prosecutors had already been diverting children for petty offences prior to the legislation being passed. ${ }^{231}$ For more serious offending, children must attend a preliminary inquiry to determine whether the child accepts responsibility for the offending, and if so, whether the child can be diverted. If a suitable service provider has been identified in the pre-trial assessment report, the service provider should attend the preliminary inquiry process to discuss the diversion option recommended.

\section{Courts}

In South Africa, Child Justice Courts are defined as any courts which deal with matters pertaining to children below the age of 18 years as per the provisions in the Criminal Procedure Act 51 of 1977 and the requirements under the CJA. Magistrates or High Court judges can preside over child justice cases. Any cases heard involving children must be held in camera. The child must be assisted by a parent, guardian or an appropriate adult when appearing at a child justice court. In situations where a parent, guardian or an appropriate

\footnotetext{
${ }^{228}$ Section 48 of the Child Justice Act 2008

${ }^{229}$ Section 11 of the Child Justice Act 2008

${ }^{230}$ Any child deemed in need of care and protection by the prosecutor cannot automatically be diverted and must be referred for a preliminary inquiry.

${ }^{231}$ Interview with Dr Ann Skelton dated 28 September 2009.
} 
adult cannot be traced, a presiding officer may decide to waive this obligation in the interest of proceeding with the matter as quickly as possible (Gallinetti, 2009:51).

Sentencing options available to the Child Justice Court include fines and restitution, ${ }^{232}$ a range of community-based options such as those available as community-based diversion options $^{233}$ and correctional supervision, whereby a sentenced child is monitored in the community by a probation officer (similar to a Supervision with Activity order for young people in New Zealand which is managed by a youth justice social worker). For children above the age of 14 years, this can include a period in safe custody prior to the correctional supervision by a probation officer. This is similar to Supervision with Residence orders in New Zealand. ${ }^{234}$

Where the decision is made for a child to be held in residence for a period of time, the child can be sentenced to a 'child and youth care centre'. ${ }^{235}$ Such a sentence cannot exceed a period of five years "or the date when the child in question turns 21 years old, whichever date is earliest". ${ }^{236}$ An unusual provision was included for children who commit the most serious offences under Schedule 3 of the CJA. This provision states that a child can first be sentenced to a child and youth care centre ${ }^{237}$ and then still be sent to prison after five years. ${ }^{238}$ Skelton explained that this became a significant point of contention between her and Parliament who insisted on a tough detention option for the most serious offending:

I absolutely lost it when I heard this! Imagine seeing your child sent to a place specialising in child offenders and then at the end of it saying you can go off to prison...I just said, 'You just can't do that to somebody - that 's just so inhumane!'...They got very tough. This was one of the big fights that we had at Parliament. They said 'You must draft it in a way that's constitutional then, if you think it's unconstitutional'. So the only way that I could think of that I could make it work (seeing as they were insistent on it) is to say that at the end of the five years you come back to court, and you would consider whether or not the child has progressed...Then at least you

\footnotetext{
${ }^{232}$ Section 74 of the Child Justice Act 2008

${ }^{233}$ Section $72(1)$ of the Child Justice Act 2008

${ }^{234}$ Section 276(i) of the Criminal Procedure Act 51 of 1977

${ }^{235}$ As described under the Children's Act

${ }^{236}$ Section 76(2) of the Child Justice Act 2008

${ }^{237}$ Formerly referred to as reform schools under the Department of Education, but which are being shifted to the Department of Social Development

${ }^{238}$ Interview with Dr Ann Skelton dated 28 September 2009.
} 
could say to the kid, 'look, you've got a chance here. If your behaviour is good and you've progressed, you can be out after five years. But if you misbehave, you will end up back in the prison system and there won't be anything we can do to save you'. Then at least there would be court oversight over it. And so, that is how it eventually went in. ${ }^{239}$

Imprisonment is a sentencing option available for children above the age of 14 years, and only as a measure of last resort for the shortest period of time. This sentence is also reserved for children who have committed Schedule 3 offences, or if there is a compelling reason to sentence a child above 14 years to prison who has committed offences under Schedule 1 or 2. Any child sentenced to a Scheduled 1 offence must have prior convictions in order to be considered for a term of imprisonment. No term of imprisonment can exceed twenty-five years for a child. While these provisions have been made available in South Africa's child justice legislation, New Zealand does not include provisions for sentencing children and young people to imprisonment. As noted above, children and young people in New Zealand who commit the most serious offences will be transferred to the adult jurisdiction for sentencing, which can include long terms of imprisonment.

The issue of minimum sentencing was also a point of debate during the parliamentary process in South Africa. Parliament had initially included minimum sentences in the Act as another measure to illustrate their commitment to being tough on crime. Skelton explained that she chose to not put up much of a fight around this during the process, as she was confident that she would be able to litigate against it in Constitutional Court. She achieved this in July 2009, with the Constitutional Court ruling that minimum sentencing is unconstitutional for children. ${ }^{240}{ }^{241}$ As a result, minimum sentencing is not allowed for children under the age of 18 years. Sloth-Nielsen described the significance of litigation in the process of youth justice. She noted:

Once we decide to litigate, so hold government to law and hold promises, constitutional promises, it signalled a different relationship with the NGO's ...It does mean that government realises that it can be sued...I think that's both a strength and a challenge is the concept of a constitution and $a$ legislation which you can litigate on. At the end of the day, it isn't just about

\footnotetext{
${ }^{239}$ Interview with Dr Ann Skelton dated 28 September 2009; Section 76(3) of the Child Justice Act 2008

${ }^{240}$ Interview with Dr Ann Skelton dated 28 September 2009

${ }^{241}$ Centre for Child Law v Minister for Justice and Constitutional Development and Others dated 15 July 2009
} 
the government making promises, but there are legal commitments which you can use, which can also be a challenge. ${ }^{242}$

Decisions around sentencing can also be determined through a restorative justice process such as an FGC or VOM whereby a plan is presented to the presiding officer at the Child Justice Court for consideration. The legislation does not specify under what circumstances a restorative justice sentence can or should be ordered by the court. It appears that it is up to the court whether it wishes to call for a restorative justice process to assist with decision-making. Restorative justice processes such as FGCs and VOMs in South Africa are facilitated by either a probation officer or an accredited diversion programme service provider.

\section{Challenges of Implementation}

Key youth justice role players in New Zealand and South Africa were satisfied with the inclusion of key principles in their youth justice legislation. The procedural nature of many sections of these pieces of legislation also helped to provide some operational guidance. However, these ambitious youth justice systems require adequate resources in order to provide quality services that reflect the vision underpinning the legislation. Services that support children's rehabilitation and reintegration also need to be widely available in order for the systems to be effective. Both New Zealand and South Africa have faced numerous challenges when turning policy into practice in both countries. While New Zealand has had more time to experience and work through some of their challenges, at the time of writing, South Africa is still in its early stages of implementation. Nevertheless, South Africa is already faced with some of the difficulties of turning its policy into practice, some of which are similar to those New Zealand is still grappling with.

\section{Practitioners}

The new youth justice systems in New Zealand and South Africa required both countries to identify suitable practitioners who would be responsible to implementing processes that had not previously existed. Both countries chose to select practitioners with either a set of personal life experiences or individual characteristics, or based on exiting roles with responsibilities that would most closely match their needs. In New Zealand, youth justice coordinators were originally recruited based on their good knowledge of the community as well as their demonstrated ability to connect with young people and encourage them to take

\footnotetext{
${ }^{242}$ Interview with Prof Julia Sloth-Nielsen dated 16 October 2009.
} 
responsibility for their actions. They were not required to have any specific formal qualification, but rather an ability to facilitate the FGC as well as encourage young people, families, victims and communities to embrace the underlying principles. The intention was to have minimal professional involvement at the conference, but rather to enable the participants to drive the process and the outcomes. According to Angus, "I think there was a lot of optimism about the youth justice coordinators who became passionate about family group conferences and built alliances with youth aid - a strong group of people". ${ }^{243}$

With little training or specific operational tools, the first youth justice coordinators were guided by the principles of their youth justice legislation and used personal judgement and experience to bring it to life. However, according to Judge Carruthers, the lack of training and support for these youth justice coordinators left the new youth justice system vulnerable, particularly in cases with sensitive or dangerous family dynamics which the facilitators did not have the skills to deal with:

One of the big problems we had was the lack of training for facilitators. When we appointed family group conference coordinators in '89 for both care and protection and for youth justice, a number of people had been working with this sort of model, but there was no training for it because no one knew what to do. Màori thought they knew exactly what to do because it's an ancient way of working. Others tried to systematise it. But what was lacking was a hard-eyed look at what the skills were and what the professional conduct aspects were, how to systematise those and how to train for them...There were some tricky areas with a whole lot of complications that you had to be aware of otherwise you can do great damage. You can end up making things worse if you're not professional about how you set it up and how you manage it. ${ }^{244}$

In addition to the training needs of FGC coordinators, tensions started to emerge between youth justice and care and protection arms, not least of all because of the additional prestige and higher salaries originally awarded to the youth justice coordinators. At first, funding for youth justice was abundant as a number of residential facilities had closed down to make way for the more community-based approach. Funding for these residences was initially

\footnotetext{
${ }^{243}$ Interview with John Angus dated 8 December 2009.

${ }^{244}$ Interview with Judge Carruthers dated 17 February 2010.
} 
redirected to youth justice FGC processes. This included selecting individuals to locate the most appropriate support people for the young person. The additional funding also allowed for more participants to attend the conference. However, as the funds dissipated, youth justice FGCs became watered down:

It started off with so much money we could do anything. We brought relatives back from Australia for family group conferences and that sort of thing, which was terribly good fun, and very helpful and successful. We closed $3 / 4$ of the institutions because we weren't putting kids into custody. All this money we were promised would go into this new way of thinking got moved off to something else, which inevitably happens. We had an open cheque book and then eventually the money eroded. So you ended up with quite the reverse, with people having $\$ 10.50$ for each conference, (which was the only discretionary amount to spend), so less and less people could come to the conference, and the less people you had there the more impoverished they were. ${ }^{245}$

In Judge Becroft's view, when times get tough, care and protection has tended to receive priority over youth justice for funding (Becroft 2003). According to Maxwell:

Allison and I argued in those days, that the conferences should have been put in an independent institution. You really need your youth justice coordinators outside of the child welfare system, because their money was taken - it vanished very easily. ${ }^{246}$

The requirement to distribute CYF funding among both care and protection and youth justice resulted in various restructures. These restructures reduced the status of youth justice coordinators and shifted their management to social work managers, leading to disappointment among the youth justice coordinators. Judge Becroft thought that the restructuring limited the importance of youth justice FGCs:

There was a turf war with tertiary qualified social workers - when often coordinators weren't: 'Why should they be in a more exalted position than social workers?' There was a real struggle with the trade unions to get

\footnotetext{
${ }^{245}$ Interview with Judge Carruthers dated 17 February 2010.

${ }^{246}$ Interview with Dr Gabrielle Maxwell dated 29 March 2010.
} 
coordinators up to where social workers were or coordinators down to where social workers were...I think that was an internal battle within CYF as to the role of coordinators and I think subtly the role of conferences, and I think the social work model won out....The coordinators are seen a little bit as functionaries rather than the touchstone of youth justice.

The former chief social worker, Shannon Pakura noted that 'the failure to think through the nature of the new position (youth justice coordinators), its relationship to the statutory social work position and the importance of ongoing alignment between the two resulted in a problem of our own making that need never have been' (Pakura 2004:119).

Given that South Africa's child justice processes had been tried and tested for some years prior to the passing of the legislation, by the time the legis lation came into force there was already a good indication of how it would work in practice. According to Graser:

During the period of time when it was not an Act, when it was still a Bill, many magistrates across the country were already implementing the provisions of the Bill as if it had been an Act. So the kind of things we trained probation officers in already functioned as if the Act was already being implemented for a number of years. ${ }^{247}$

However, prior to the Act, there was no obligation for the government to fund the requirements of the legislation across the country. Furthermore, while the IMC pilot projects allowed for flexibility and experimentation, once the law had passed, the processes needed to be regulated to ensure they met the required standards. ${ }^{248}$ This meant that justice officials and police had to take responsibility for their new processes, while the DSD provided the means of implementing the various community-based aspects of the legislation across the country. Providing sufficient funding and oversight for diversion programmes from a range of service providers in diverse settings from urban to rural soon became a challenge for the DSD ${ }^{249} \mathrm{~A}$ researcher for the justice portfolio committee explained that key agencies had been consulted on their capacity to implement the provisions of the new legislation during the consultation process before the legislation was passed. While the agencies were required to provide

\footnotetext{
${ }^{247}$ Interview with Dr Graser dated 5 May 2012.

${ }^{248}$ Meeting with Steven Maselesele, Director of Social Crime Prevention at the National Department of Social Development in Pretoria dated 9 March 2011 as required by Section 56 of the Child Justice Act 2008 which deals with "Provision and accreditation of diversion programmes and diversion service providers".

${ }^{249}$ Meeting with Steven Maselesele, Director of Social Crime Prevention at the National Department of Social Development in Pretoria dated 9 March 2011.
} 
assurances, she noted that a central challenge existed around coordinating funding when dealing with a variety of government agencies:

Implementation is always going to be a problem, particularly when you are dealing with more than one department, because they have ways of operating, and different budgets. The other thing is how to get the budgets in line. ${ }^{250}$

South Africa's probation officers experienced similar tensions to New Zealand's youth justice coordinators with regard to their position in relation to generic social workers. In South Africa, probation officers are expected to first qualify as social workers, after which they must complete a variety of trainings in order to undertake the specialist tasks of a probation officer. This training could include a post-graduate degree in probation practice offered at certain universities, initially in preparation for the implementation of the new youth justice legislation. During this period, there was a drive to distinguish probation services from generic social work, given the specialist skills and knowledge needed to undertake probation tasks. In 1996 a Probation Advocacy Group was set up. With the additional specialisation needed by probation officers, the Advocacy Group worked on establishing a professional board and the DSD set up a Standards Generating Body in 2004 to outline the training needs of probation staff. ${ }^{251}$ With the developments taking place in the child justice sector and a professional status being considered for probation officers, the enthusiasm of practitioners was palpable, and their dedication, knowledge and application of the provisions of the proposed legislation helped to convince the members of the Portfolio Committee of the new child justice system's potential. A researcher for the Portfolio Committee explained her perceptions of one of the Committee's visits:

We did a very nice site visit to Bloemfontein to the One-Stop Child Justice Centre. You could just see how the officials there had such a compassionate attitude, and almost a zealous attitude to what they are doing. There's a commitment to making a difference. ${ }^{252}$

\footnotetext{
${ }^{250}$ Interview with researcher for the South African Justice and Constitutional Development Portfolio Committee dated 8 October 2009.

${ }^{251}$ Ibid

${ }^{252}$ Interview with researcher for Portfolio Committee for Justice and Constitutional Development dated 8 October 2009.
} 
Over time, the impetus to distinguish probation officers as an independent profession waned, particularly with the stepping down of the key lobbyists driving the campaign (Gray and Lombard, 2008). According to Gray and Lombard (2008:7) after years of restructuring social welfare to accommodate the more general social needs by the end of apartheid:

... the fact that most probation officers are also social workers has not been properly investigated or acknowledged...Thus, the initial drive for a professional board for probation officers came from a strong advocacy group within the sector, and when two key facilitators resigned from the government department a review revealed that probation officers, were in fact, leaning towards applying for recognition as a speciality field in social work.

In South Africa, another event that overshadowed the probation service was the new Children's Act in 2005. Although the drafting of this comprehensive piece of legislation only gained momentum after work had begun on the CJA, most of the provisions related to care and protection matters were passed before the CJA come into force. This drew attention away from the CJA and increased the demands on social workers, who might otherwise have preferred to work as probation officers. ${ }^{253}$ Given that probation officers did not receive professional status in their own right, their role became increasingly interchangeable with other generic social work functions. At the same time, due to the shortages of trained probation officers, a number of untrained social workers were rotated into the roles of probation officers, thereby undermining the quality of the service. As such, probation staff lost enthusiasm for the role. According to Gxubane:

It's a huge challenge because we don't have enough probation officers. One of the problems with probation in South Africa is that you will find there is a high turnover because they don't get the recognition they deserve. Probation officers are also asked to do all sorts of other things at the same time, so people don't feel that sense of growth and specialisation. ${ }^{254}$

Graser considered that the decline in impetus to promote probation officers in South Africa is the result of the social work profession feeling threatened by the rise of probation services. Skelton and others believe that a way around the 'poaching' of probation officers to

\footnotetext{
${ }^{253}$ Interview with Dr Ann Skelton dated 29 September 2009.

${ }^{254}$ Interview with Thulane Gxubane dated 13 October 2009.
} 
undertake other social work tasks is to be able to draw in staff from other relevant sectors such as criminology or psychology who would have relevant skills and training. It appears that this option has been slow to generate support. Nevertheless, Graser commented that responding to community needs should remain the priority, irrespective of the status of any of the practitioners. ${ }^{255}$ In his view, this includes working directly alongside people in the community. He stated:

I think the answer lies in stopping to worry about our profession and look at what the needs are and doing the best thing to meet the needs. We must remember that South Africa is part of Africa... We have massive, massive problems in our communities with AIDS and poverty and crime. A few social workers cannot meet that... We need to change our whole focus from a highly professional service to a service where thousands of people go into the community and render the service there. ${ }^{256}$

\section{Staff training}

While having sufficient staff is important, appropriate training is a key aspect of successful implementation. Mike Batley, the head of South Africa's Restorative Justice Centre, noted that rapid staff turnover or lack of staff affects the implementation and nurturing of the values and principles that were intended to underpin the new youth justice practice. He explained that the training philosophy applied at the Restorative Justice Centre stemmed from the IMC model when the FGC pilot projects were being implemented. It was referred to as the 'head, heart and hands' model, geared towards instilling a holistic operating approach. However, he acknowledged that while this might work for small groups in the NGO sector, trying to achieve the same goal across entire government departments is harder. He reflected that:

To get people on board, really infuse the values and to monitor their functioning within the values of the organisation and the philosophy is a huge amount of effort. So I think if you take a large department and the department is generally less concerned about values, then this slips away and it becomes very much an individual thing. ${ }^{257}$

\footnotetext{
${ }^{255}$ Interview with Dr Graser dated 5 May 2012.

256 Ibid

${ }^{257}$ Interview with Mike Batley dated 30 September 2009.
} 
An additional risk identified by Muntingh when trying to up-skill a number of staff is that the training can become rigid and the application can be done in a "very rudimentary or mechanistic way" 258 without the correct level of knowledge or instinct to do the job to a high standard. However, Frank cautioned that no matter how good the training is and enthusiastic staff may feel afterwards, if the conditions at the place of work do not accommodate the new learning and staff's eagerness, staff can quickly become disillusioned. Like Batley, she notes that effective implementation of values and principles as well as new ideas and ways of doing things often becomes a matter of individual drive:

It's a nice thing to rally around at the time, but when it comes to what you as an individual probation officer do, there needs to be a kind of missionary zeal attached to delivering a high level quality and a particular result for that child and that family. But even in those times when you have trained people, when they go back to their work, a lot of the excitement is really tempered by what happens in their work environment. ${ }^{259}$

Maxwell considers that this can be addressed by having appropriate trainers and support people that can adapt to the needs of each context. In her view, if the trainer does not embrace the values and principles, the principles are less likely to be assimilated and applied:

\section{Government agencies tend to use professional trainers, and unfortunately you can't change a culture if you're going to employ professional trainers - they tell you 'how to', and not 'why'. Employ people who teach from the principles and give people who work in it the responsibility to implement it in the ways that they see fit within their own communities. ${ }^{260}$}

Gxubane notes that the practitioners need to work with passion for the work to be effective. He explained:

You need passion to work with offenders. You need passion generally, without a monetary reward. I suppose if people come in and they are rewarded for the effort that they put into their work, maybe some of the passion will come along the way. Once you have that passion that will keep you going.

\footnotetext{
${ }^{258}$ Interview with Lukas Muntingh dated 1 October 2009.

${ }^{259}$ Interview with Cheryl Frank dated 28 September 2009.

${ }^{260}$ Interview with Dr Gabrielle Maxwell dated 29 March 2010.
} 
In order to implement the youth justice systems envisioned by the advocates and policy makers in New Zealand and South Africa, there needs to be sufficient staff to meet the communities' needs, a training approach that can instil a similar sense of passion and enthusiasm in the staff that underpinned the design of the systems, and a work environment that supports and fosters the application of the core values and principles.

\section{Quality and Accessibility}

While selecting and training good practitioners is important for the successful implementation of new policies, ensuring widespread access to high quality services helps to provide assurances that the system is viable, thereby making it more likely to endure. As Frank notes:

There are all these battles that still have to be fought in order for us to still get a system that's workable and clean and something that children are really going to benefit from. For me, the issues are always access and quality. How do we get it happening in the areas like Noupoort that are all over the place and they have courts that sit once a week, and you have children sitting in cells for a week? And then the quality issue is what happens to that individual child and his or her individual experience of the criminal justice system, and how that prosecutor behaves, how that social worker behaves in the context of the relationship with that child. ${ }^{261}$

Judge Carruthers noted the same types of concerns crept into the youth justice system over time in New Zealand. One reason was because New Zealand was the first country to implement its new approach to youth justice, particularly with regard to FGCs, so it had limited points of reference from which to evaluate its success. Furthermore, as money ran out and demands on staff increased, the emphasis on quality deteriorated:

I saw conference coordinators having too much to do, too many conferences to run, so you couldn't put the energy into each of them. I saw really good police diversion, but that was patchy and it wasn't throughout the country. So I think the predominant thought for me was that although the work was done well, the growing way in which coordinators'status was lost within

${ }^{261}$ Interview with Cheryl Frank dated 28 September 2009. 
the Department and came down to that of what was social work, meant that you weren't getting the really key, energetic, visionary people doing that important task...The imagination and the energy about doing something different seemed to be drying up. But every so often you'd find examples of something new and fresh which revives you too. I remained optimistic, but it was a struggle. ${ }^{262}$

As in New Zealand, a key challenge to maintaining a good quality service in South Africa is related to funding and staff capacity. With high numbers of children and young people regularly entering into the youth justice system in South Africa, it is difficult for staff to keep up with the demands. According to Muntingh, this starts with the high number of police arrests, resulting in children unnecessarily being kept in custody without proper monitoring. He explains that this has a ripple effect throughout the system, including in the Child and Youth Care Centres:

I am not convinced about the quality of oversight over Child and Youth Care Centres and whether that will actually be done properly, because it should be done in a manner that is in line with international law...If children are detained and are deprived of their liberty it's effectively a prison. So let's be honest about this. Assaults do take place, and if an assault by an official takes place, it's called torture. I tried to get something of that into the regulations and the message got back to me that: 'No, we're child care workers, we don 't torture children!' Well, actually you do. It happens, it has happened, it will continue to happen. So unless you have independent oversight over the Child and Youth Care Centres, you are going to run into problems. So I think it is more about quality. ${ }^{263}$

While monitoring the quality of facilities and services for children in detention facilities is a challenge in South Africa, it is important to ensure that sufficient quality options that meet children's rights and the interests of community safety are available to divert children from custody. According to Skelton:

We don't necessarily have coverage all over the country for all the different kinds of diversion. You probably have got diversion programmes in every

\footnotetext{
${ }^{262}$ Interview with Judge Carruthers 17 February 2010.

${ }^{263}$ Interview with Lukas Muntingh dated 1 October 2009.
} 
province, and most towns, but there'll still be places where you don't have any. So, I think that is one of the big challenges, providing a range of diversion services throughout the country. ${ }^{264}$

South Africa was fortunate that a number of diversion services became available during the years leading up to the passing of the legislation, particularly by NICRO and some other smaller NGOs. While a set of minimum standards for diversion were developed during this period, there were no requirements for service providers to be accredited prior to the passing of the legislation. These regulations were introduced once the CJA became law. According the Steven Maselesele, the Director for Social Crime Prevention for South Africa's DSD, prior to the accreditation requirement it was difficult to find out the details of diversion programmes being delivered. ${ }^{265}$ Section 56 of the CJA provides guidelines for accrediting diversion service providers. While giving priority to NGOs established in providing the service, if these service providers did not meet the accreditation criteria, there was no guarantee that they could continue providing the service, and courts could not refer a child to their service. Maselesele explained that the policy framework requires national bodies to consider the applications for accreditation, to conduct site visits and to provide quality assurance systems. Once accredited, accreditation can last for up to four years. However, a service provider can become de-registered if the service is not being delivered to the required standard. They may then be sent through a quality assurance process before being able to practice again, and courts will be alerted to their status. Gxubane believes that the complicated accreditation process risks stifling the availability of services, particularly in the more remote rural areas where it may be difficult for service providers to meet the lofty and rigid government accreditation requirements. He reflected:

Some of us argued that that is going to limit the pool. Okay, set minimum standards, but anything that is offered where there is nothing, we need to support and help them to come up with something rather than discouraging it. We are discriminating against children who are coming from this kind of background. We need to look at creative ways of dealing with it, but

\footnotetext{
${ }^{264}$ Interview with Dr Ann Skelton dated 28 September 2009.

${ }^{265}$ Meeting with Steven Maselesele dated 10 March 2011.
} 
unfortunately it's one of the issues we will face with accreditation in the Act.

It's limiting. ${ }^{266}$

\section{Conclusion}

Both New Zealand and South Africa sought ways to operationalise their youth justice policies and legislation in a way that would uphold the principles underpinning the legislation. However, both countries have found that making quality services widely available is difficult. In order to fulfil the intentions of the principles, committed and skilled practitioners are required to undertake the tasks. Good support, oversight and processes of accountability are needed to ensure that the system is allowed to thrive and survive with integrity. Implementing administrative processes can help to some extent to provide a framework for evaluating the quality and spread of services. However creating overly bureaucratic procedures can distract from the spirit in which the key aspects of these youth justice systems were designed, which called for flexibility and responsiveness to situations on a case by case basis. Ironically, it seems that the blueprint for the youth justice systems in New Zealand and South Africa operated better either prior to or in the early stages of the formal implementation of the systems.

${ }^{266}$ Interview with Thulane Gxubane dated 13 October 2009. 
PART II:

Theories, patterns and lessons 


\title{
Chapter 7
}

\section{How international standards for children's rights are evident in New Zealand and South African}

\section{youth justice systems}

\begin{abstract}
Human rights, from which many of the rights of the child are derived, are concerned with both the protection of the individual from the state and the creation of societal conditions by which all individuals can develop their fullest potential.
\end{abstract}

Van Bueren (1995:4)

This chapter unpacks some of the significance of international standards for children's rights in New Zealand and South Africa's youth justice systems. This includes the extent to which youth justice standards influenced the design of each country's youth justice policies and legislation, the ways in which international standards are evident in each country's youth justice systems and where both countries have fallen short of meeting the international standards for youth justice. It starts by tracing aspects of the evolution of international standards for children's rights, with a focus on the genesis of rights for children in conflict with the law. This analysis illustrates how processes and factors that drove international standards for youth justice were similar to the processes of youth justice transformation in both countries. It also helps to confirm the value of applying general children's rights principles to this specific group of children, including their rights to participate in decisions about matters that affect them and the role of the family and community in supporting their wellbeing and reintegration. This chapter also highlights how international youth justice standards were designed to take into account the broader socio-economic factors that affect children and young people's development and contribute to their offending behaviour.

\section{The development of international standards for children's rights}

In 1923, the League of Nations adopted the first Declaration of Children's Rights (Declaration of Geneva) following Elgantyne Jebb's submission of her seminal proposal. This Declaration of Geneva comprised the following five key principles: 
1. The child must be given the means requisite for its normal development, both materially and spiritually.

2. The child that is hungry must be fed, the child that is sick must be nursed, the child that is backward must be helped, the delinquent child must be reclaimed, and the orphan and the waif must be sheltered and succoured.

3. The child must be the first to receive relief in times of distress.

4. The child must be put in a position to earn a livelihood, and must be protected against every form of exploitation.

5. The child must be brought up in the consciousness that its talents must be devoted to the service of its fellow men.

Jebb was a social activist who co-founded the International Save the Children Union. She developed these principles while reflecting on the needs of vulnerable children she had recently worked with affected by war and famine (Mulley, 2009). Jebb believed there needed to be some degree of state commitment to ensuring that children's basic needs are met at all times, even under the most difficult circumstances, and to ensure they are provided with opportunities to develop into productive citizens (Mulley, 2009). According to Van Bueren (1995:7), it was not the League's intention at the time to place "binding responsibilities on states", but the Declaration of Geneva was designed to recognise adult responsibilities to protect and provide proper social guidance to children given their inherent vulnerability. This five-point declaration became the founding document for subsequent discussions on children's rights.

In 1948, the Universal Declaration of Human Rights included some general provisions for children's rights. Specific references to children are found in Article 25(2) which states that: "Motherhood and childhood are entitled to special care and assistance. All children, whether born in or out of wedlock, shall enjoy the same social protection" and, in Article 26 which states that: "Parents have a prior right to choose the kind of education that shall be given to their children". Children's rights activists at the time thought that the Universal Declaration of Human Rights fell short in terms of highlighting the unique importance of protecting children's rights, given their inherent vulnerability and lack of maturity. As a result, a new ten-point Declaration of Children's Rights was adopted by the United Nations General Assembly in November 1959. The ten points in the UN Declaration of Children's rights placed greater emphasis on certain areas, for example, in response to situations where the risk of neglect and ill-treatment of children was greatest. More consideration was also given to 
specific rights aimed at enhancing children's development, with the preamble altruistically noting that "mankind owes the child the best it has to give". The UN Declaration of Children's Rights 1959 also introduced the concept of the 'paramountcy principle' in 1959 stating:

The child shall enjoy special protection, and shall be given opportunities and facilities, by law and by other means, to enable him to develop physically, mentally, morally, spiritually and socially in a healthy and normal manner and in conditions of freedom and dignity. In the enactment of laws for this purpose, the best interests of the child shall be the paramount consideration (my emphasis).

The issue of whether the best interests of the child should be of paramount consideration has led to much debate since its inception, largely due to cultural divergence over the role of the child in society. While all cultures acknowledged the key principles underlying child protection and development, in many countries the notion of the child's best interests being paramount over the overarching functioning of the family unit was rejected. In the initial stages of reviewing the Children and Young Person's Act of 1984 in New Zealand, John Rangihau stated that the paramountcy principle:

...subsumed the importance attached to the responsibility of the tribal group, through tribal traditions and lore, which took precedence over the view of birth parents. Thus children's interests could only be determined after having regard for, and giving due consideration to the views and concerns of the children's whänau and hapū (Department of Social Welfare, 1987:9).

This provides an example of concerns expressed in relation to the idea of children's rights being the paramount consideration. Nevertheless, John Rangihau's views were not inconsistent with promoting the best interests of the child, which he still believed should be upheld in decisions made by the whanau and hapu or the family group. The subsequent FGC design encouraged families to decide what responses and steps would enable their children and young people to take responsibility for their actions while still protecting their children's best interests. 
According to Van Bueren (1995), the two initial Declarations of Children's Rights were well meaning and provided a special focus on children. However, they were not binding and therefore resulted in little change to domestic policies around the world. It appears from Van Bueren's reading of this history that interest in children's rights regained momentum in the 1970 's, as global concern for the wellbeing of children appeared "less divisive" than other global issues, and apparently provided a more uniting platform for international diplomatic discussion (Van Bueren, 1995:25).

The launch of the United Nations Convention on the Rights of the Child (UNCRC) in New York in 1989 saw more heads of state and government gathering to sign the document than any other before. The UNCRC ultimately lowered the bar from the former paramountcy principle, noting that the "best interests of the child" must be "a primary consideration" rather than a paramount consideration (Van Bueren, 1995:46). Despite this, the new South African Constitution promulgated by President Mandela on 19 December 1996 and underpinned by universal standards for human rights included that the best interests of the child should be of "paramount importance in every matter concerning the child" (Section 28(2), Act 108 of 1996). This illustrated South Africa's commitment to improving outcomes for its children, after extensive levels of abuse and neglect during the apartheid era. South Africa's Constitution was drafted in a way that took into consideration the country's unique circumstances including its history, diversity and blend of western, African, modern and traditional lifestyles.

The UNCRC became a binding document to those who ratified it. However, Detrick (1992) points out that a key difference between international law and domestic law is that while international law may be binding, there is no enforcement mechanism for state parties who choose not to adhere to the principles. Nevertheless, she believed that the unprecedented signing of the Convention by the vast majority of nations created "a powerful moral obligation to comply with the Convention's standards" (Detrick, 1992: 640). However, international standards for children's rights have at times led to controversy and rejection when it comes to domestic application, particularly where there is uncertainty as to whether domestic principles clash with international standards. The UNCRC was developed through a process of consensus in working groups (Detrick, 1992) and therefore endeavoured to be sensitive to cultural diversity in its approach. In relation to the issue of cultural relevance, An-Na'im (in Alston, 1994:63) acknowledged that "while maintaining that this inherent tension cannot be eliminated altogether...it can and should be mediated and somewhat 
contained through procedures and processes". Na'im suggests that there should be an interface between what he refers to as "folk models" and international standards, whereby international standards founded on "global, ethical, social and political values and institutions" take into account and promote cultural diversity and nuances, thereby legitimising the application of international standards (Al-Na'im in Alston, 1994:71).

\section{International standards for the rights of children in conflict with the law}

While recognition of children's vulnerability and the need to develop international guidelines to uphold their best interests in general progressed over time from the first five-point declaration in 1923, the rights of children in conflict with the law received little attention in the initial stages of children's rights deliberations. Until the 1980's, identifying the vulnerability of children in the criminal justice system had been limited to mentioning the need to separate accused children from adults in the 1955 Standard Minimum Rules for the Treatment of Prisoners (UNICEF, 1998:2) and an acknowledgement of children's age and their requirements for rehabilitation in the 1966 Covenant on Civil and Political Rights (Van Bueren, 1995:170).

The first concerted effort to address the rights of children in conflict with the law was during the United Nations Sixth Congress on the Prevention of Crime and Treatment of Offenders held in Caracas, Venezuela in 1980. This Congress addressed the theme of "Juvenile justice before and after the onset of delinquency" and noted that addressing the needs of children either at risk of becoming or in conflict with the law while they were still developing was one of the key approaches to dealing with crime prevention more generally (United Nations Sixth Congress:3). The Congress agreed that the issue of children in conflict with the law and delinquency could not be separated from the broader socio-economic context and history which is generally likely to have contributed to their behaviour. The Congress noted:

The study of the juvenile justice system would be meaningless without an initial examination of the social fabric from which it emerged and in which it operates, the values and norms of the society in which it functions and the over-all complexities of the social, economic and political structure of society (United Nations Sixth Congress:3).

In acknowledging the relevance of the socio-economic context to understanding and addressing the needs of children who offend, the committee also noted that society therefore 
had a responsibility to address delinquency both individually and collectively. They referred to the key social units as, "the roles of family, education, community and the state and their responsibilities for the development of children and young persons" (United Nations Sixth Congress: 9).

The concept of the role of the family (including the extended family and community) became an important underlying principle in the evolution of a children's rights-based approach to dealing with children in conflict with the law. By the time the UNCRC was launched, the importance of the extended family in taking responsibility for children's well-being had become well recognised. Article 5 of the UNCRC included the role of the extended family in contributing to child protection, development and social integration. This responded to international cultural diversity where many countries place significant importance on the role of the extended family in caring for children. Article 5 of the UNCRC states that:

States Parties shall respect the responsibilities, rights and duties of parents or, where applicable, the members of the extended family or community as provided for by local custom, legal guardians or other persons legally responsible for the child, to provide, in a manner consistent with the evolving capacities of the child, appropriate direction and guidance in the exercise by the child of the rights recognised in the present Convention.

Strengthening the family's capacity to care for children and support their social development was highlighted as a key strategy to addressing delinquency by the UN Sixth Congress. This thesis underscores the importance of family involvement in the development of both New Zealand and South Africa's youth justice systems, including the involvement of extended family members and the community. In New Zealand this came through strongly during the community consultation process led by the Māori Advisory Committee and later by the Ministry of Social Welfare officials. Families expressed their dismay at government social workers taking away their children and placing them in state institutions without their input or regard for their customary child rearing processes which promoted their reintegration into the community. While South Africa's policy makers did not expressly consult with families of children in conflict with the law, the experiences of families of children in detention during the 1980s' state of emergency were well known to many South African policy makers, particularly as a result of activity from organisations like the South African Detainees Parents Support Committee (DPSC). As the new child justice legislation was 
being conceptualised in South Africa, Skelton (in Glanz, 1994:104) reflected that "new legislation should ...encourage the mobilisation of families and communities towards finding solutions and working for a reduction of juveniles offending”. In designing a range of responses to deal with children at risk in South Africa along a continuum of care, the IMC also emphasised the importance of family and community, noting that the "resourcefulness of each child should be promoted by providing opportunities for the resourcefulness of each child" (Inter-Ministerial Committee for Youth at Risk, 1998). This concept permeated South Africa's Child Justice Act which incorporated a range of responsibilities for parents or appropriate adults and communities when seeking diversion for children in conflict with the law and promoting their reintegration back into the community.

The UN Sixth Congress drew up four principles to guide the process of developing the minimum standards for juvenile justice. These principles were:

1- The responsibility of the community of nations, both individually and collectively to ensure opportunities for a meaningful life for the young as fully participating members of society;

2- The provision of carefully defined legal protections;

3- The use of pre-trial detention only as a last resort, with special institutional arrangements for confinement, taking always into account varying needs of the particular age; and

4- The use of institutionalisation only after adjudication for very serious offences.

These guidelines were deliberated on and drafted up during the Seventh United Nations Congress on the Prevention of Crime and Treatment of Offenders: Youth Crime and Justice, held in Milan, Italy in 1985. The result of the Seventh United Nations Congress was the adoption of the United Nations Standard Minimum Rules for the Administration of Juvenile Justice in 1985, more commonly known as the 'Beijing Rules'. These standard minimum rules became the first comprehensive framework for considering the rights of children in conflict with the law. In the spirit of the principles identified by the Sixth UN Congress, the Beijing Rules placed significant importance on diverting children from criminal proceedings, only using detention as a last resort for the shortest period of time, encouraging children to take responsibility for their actions and involving the community in the positive development and reintegration of children in conflict with the law. The Beijing Rules were designed to allow for social, cultural, political and economic diversity in order for the minimum standards 
to be applied in a way that was relevant to the context. Nevertheless, the participants involved in the discussions on international standards for children in conflict with the law acknowledged that youth justice is not a priority for many nations when they are grappling with trying to provide basic needs to the majority of their children, such as food, health and education (Van Bueren, 1995:171).

Like the previous more general Declarations for Children's Rights, the Beijing Rules did not provide a binding set of standards, but rather guidance on how to uphold the best interests of the child in the context of youth justice. Nevertheless, key aspects of the Beijing Rules were incorporated into Articles of the UNCRC, specifically Articles 37 and 40, and as a result become binding through that pathway once ratified by nation states and governments.

\section{The influence of international standards for children's rights and youth justice on New}

\section{Zealand and South African youth justice systems}

While both South Africa and New Zealand have their own unique traditions for raising children, international standards for children's rights provide a general framework for nation states to develop strategies to ensure that children's rights to protection, participation, survival and development are being upheld. This section considers the extent to which New Zealand and South Africa's youth justice systems have been influenced by or reflect international standards for children's rights.

\section{Ratifying the UNCRC}

When New Zealand first started revisiting its child welfare policies in 1984, neither the Beijing Rules nor the UNCRC had been established. Therefore, New Zealand could not practically rely on these international instruments to inform its new legislation. Nevertheless, the public discussion paper on the Review of Children and Young Persons legislation released in December 1984 noted the importance of children's rights. The introduction to this paper highlighted that New Zealand had responded to the International Year of the Child in 1979 by setting up the National Advisory Committee on the Prevention of Child Abuse (NACPCA). Some policy makers in New Zealand were aware that the United Nations was working on a set of standards for children's rights at the time they were drafting their new legislation. The New Zealand government had sent a representative delegation to the deliberations in the late 1980s. Ludbrook, who was present in Geneva as the UNCRC was being developed, recalled how he inadvertently became involved in the process: 


\begin{abstract}
About 1987, I got appointed to be the New Zealand delegate at a conference in Geneva at the United Nations on Human Rights education...Along the corridor, the finishing touches were being put to the United Nations Convention on the Rights of the Child - so I sat in on this which really interested me. The New Zealand delegation were not lawyers and knew nothing about the law relating to children, so I was able to help them. ${ }^{267}$
\end{abstract}

Beyond this, New Zealand relied primarily on local needs and interests through public consultation rather than on international debates about children in conflict with the law when developing its youth justice system. Ironically though, New Zealand's original youth justice provisions in the CYPF Act, which came into force the same year as the UNCRC, soon became commended internationally for their compliance with international standards for youth justice. In Judge Becroft's view, this was not evidently the result of any conscious effort on behalf of the policy makers at the time. He explained:

In New Zealand we have a 'No. 8 Fencing Wire' approach. We took a rather idiosyncratic, individualised approach that maybe only a small isolated country can take, that seemed to be consistent with the UNCRC convention that came out at the same time!...I think it was almost by accident that the Children, Young Person and their Families Act happened to harmonise. Maybe the two were born out of the same movement - so 'identical children from similar parents' - and what we came up with coincidentally reflected what was going on in the international debate. 268269

It took a few years after the CYPF Act came into force before New Zealand ratified the UNCRC on 3 April 1993. In ratifying the internationally binding document, New Zealand made the following reservations:

The Government of New Zealand reserves the right not to apply Article 37

(c) in circumstances where the shortage of suitable facilities makes the mixing of juveniles and adults unavoidable; and further reserves the right

\footnotetext{
${ }^{267}$ Interview with Robert Ludbrook dated 7 March 2010

${ }^{268}$ Interview with Judge Becroft dated 24 November 2009.

${ }^{269}$ While the CYPF Act was not specifically designed to reflect the principles of the UNCRC, it is noted that in 2003, the Children's Commissioner Act was established with one of its purposes being to better align the duties of the Commissioner with the requirements of the UNCRC. This is in the Children's Commissioner Act 2003 Part 1(3) (c-d).
} 
not to apply Article 37 (c) where the interests of other juveniles in an

establishment require the removal of a particular juvenile offender or where

mixing is considered to be of benefit to the persons concerned. ${ }^{270}$

It is not entirely clear why New Zealand chose to make these reservations, but it is assumed that they would only be applied in situations where it is considered more practical to mix young people and adults in detention facilities. ${ }^{271}$ While these reservations should only be applied as a last resort when there is a distinct shortage of adequate facilities, there is inadequate rigor around monitoring the exceptional application of these reservations, sometimes resulting in inappropriate use.

In contrast to New Zealand, South Africa was largely ostracised by the international community at the time the UNCRC was launched. As a result South Africa was not invited to attend the conference alongside the majority of heads of state and government at the United Nations in New York City in 1989. Few predicted at the time that the release of Mandela and the unbanning of opposition parties including the African National Congress (ANC) was only months away. South Africa signed the UNCRC in December 1993, when President F.W. de Klerk and Nelson Mandela were invited to do so by UNICEF, after they were jointly awarded the Nobel Peace Prize. President Mandela ratified the UNCRC on 16 June 1995, marking the symbolism of the Soweto Uprisings by hundreds of school-aged children almost twenty years before. It was also the first international human rights instrument to be ratified by the new South African government.

Sloth-Nielsen explained that in the early years of political transition, South Africans had very limited knowledge of international instruments. She noted that even she was not familiar with the concept of children's rights when asked to run the children's rights project at the Community Law Centre: "It was just an unknown territory for South African lawyers because

\footnotetext{
${ }^{270}$ Article 37(c) of the United Nations Convention on the Rights of the Child states: Every child deprived of liberty shall be treated with humanity and respect for the inherent dignity of the human person, and in a manner which takes into account the needs of persons of his or her age. In particular, every child deprived of liberty shall be separated from adults unless it is considered in the child's best interests not to do so and shall have the right to maintain contact with his or her family through correspondence and visits, save in exceptional circumstances

${ }^{271}$ Attempts were made to get more specific information about this clause from both UNICEF and the New Zealand's Department of Justice, but any responses were unable to shed light on the detail behind these reservations. It is noted that at the time of writing, there is discussion within New Zealand's Department of Corrections that mixing young persons in detention together can increase their risk and likelihood of continuing to offend. As a result, there is some discussion that it may be beneficial to mix some young people with adults in detention where the adults are at a stage in their rehabilitation that they could assist young people to desist from further offending. This approach has not been tested yet.
} 
we had been completely excluded from the international arena". ${ }^{272}$ However, according to Pinnock they soon became a touchstone for the law makers developing the new youth justice system in South Africa, and were referred to throughout the process. He explained:

The 'rights of the child' was what we were embedding. I remember one session when we went right through the rights of the child with our legislation and made sure that every piece linked up. We were promoting the Convention through what we were writing. It went in completely. It was our foundation document in many respects in how we linked into international space. The Convention was sort of happening and very prominent at the time we were writing. It was a platform internationally from which we were delivering our concepts of youth justice. Everybody who had read the Convention could understand what we were doing. ${ }^{273}$

South African child justice advocates, policy and law makers working on the CJA therefore used the UNCRC as a basis for developing the legislation, and sought to ensure that the child justice principles in Articles 37 and 40 as enshrined in the Constitution were well reflected in the proposed law changes. Sloth-Nielsen identified that: "The inclusion of key rights in the interim Constitution of 1994 and subsequently in the 1996 Constitution which have relevance for juvenile justice has ensured the lasting significance of international law provisions in domestic law" (Sloth-Nielsen, 2001:25-26). These inclusions specifically were the right for children in detention to be treated in a manner that takes into account their age, the use of detention for children as a last resort for the shortest period of time and the separation of children from adults held in custody. Developing a distinct child justice system with its own legislation constructed around international standards for children's rights was another mechanism through which South Africa could further demonstrate its commitment to the paramountcy principle in the youth justice system. The commitment to these principles is reiterated in the preamble of the CJA which notes that "the Act therefore aims to establish a criminal justice system for children, who are in conflict with the law, in accordance with the values underpinning our Constitution and our international obligations" (South Africa's Child Justice Act of 2008).

\footnotetext{
${ }^{272}$ Interview with Prof Julia Sloth Nielsen dated 16 October 2009.

${ }^{273}$ Interview with Don Pinnock dated 2 March 2011.
} 
Despite South Africa's efforts to ensure that children are separated from adults in custody, Gallinetti raised the concern that the CJA makes provision for children to be transported to court with adults. She noted that this seems in principle to contradict the intentions of the South African Constitution, and thought this was likely to be one of the issues Skelton would address through litigation. ${ }^{274}$ This provision resonates with the reservations made by New Zealand when ratifying the UNCRC.

Making national reservations when ratifying the UNCRC or including provisions counter to the spirit of the UNCRC opens systems and processes up to slippages, demonstrating a lack of vigilance and commitment to the best interest of the child. This undermines the notion that the standards laid out in the Convention should represent a bottom line for nations to strive to achieve, rather than seek ways around.

\section{Age of criminal capacity and children's evolving capacity}

In pledging their commitment to the UNCRC, nation states and governments accepted that children should participate in matters concerning them, as provided for in Article 12 of the UNCRC. This addition to the UNCRC did not exist as explicitly in the former Declarations of Children's Rights, which had been designed on the basis that children were considered passive, vulnerable members of society who required adults to speak on their behalf and uphold their rights. While the UNCRC still inherently accepts that children are vulnerable and should be protected by adults, the new concept of children's 'evolving capacity' in the UNCRC added a novel and salient dimension to the application of children's rights.

The idea that children have evolving capacities which allow them to take increasing responsibility for their actions as they mature is particularly important when considering how to respond to children in conflict with the law. Setting age limits in youth justice jurisdictions has been universally contentious since the United Nations Seventh Congress when the Beijing Rules were being established. While children in conflict with the law are still immature and vulnerable, they are also in a "process of personal development and selfrealisation" (UN Seventh Congress: 7), with which comes increased accountability and responsibility, as well as criminal capacity. ${ }^{275}$ Given that the UNCRC sets children's upper age limit at 18 years old, the provisions of Articles 37 and 40 apply to children in the criminal

\footnotetext{
${ }^{274}$ The one murder of a person under the age of 18 years in New Zealand within the justice system was by an adult prisoner while sharing transport from court without adequate restraints in August 2006.

${ }^{275}$ Also as suggested by the notion of the child's evolving capacities referred to in Article 5 of the UNCRC.
} 
justice system until they turn 18 years old. This was reinforced in the United Nations Criminal Justice Assessment Toolkit for juvenile justice (2006), which noted that when assessing compliance with international standards: "This tool is designed to apply to all children aged under 18, in accordance with the international benchmark distinguishing childhood contained in the CRC, regardless of whether the system differentiates between children and older youth, by, for example, regarding older children as 'juveniles' or as 'adults' and not children”.

Classification and nomenclature of the possible groups which fall in the age range between birth and 18 years in itself creates division and debate. For example, Abramson (in Jensen and Jepsen) believes that older teenagers do not want to be referred to as 'children' as they approach adulthood and take on more adult responsibilities. In his view, “(UN) CRC advocates say that the Convention covers everyone under 18 , but ... teenagers are marginalised. And since the young offenders are overwhelmingly teenagers, juvenile justice gets sidelined, as compared with other areas covered by the CRC". On the other hand, Cairns (1996) identified that in some instances, not referring to people up to the age of 18 years old as children has given some governments permission to ignore the inherent vulnerabilities of this group. He uses the former South African context to demonstrate this: "No politician wants to be accused of imprisoning children or worse, killing children. The solution therefore is too often to invent some other name for older children" (Cairns, 1996).

The UNCRC has, to date, deliberately not set a minimum age limit for criminal responsibility. Don Cipriani, who published a comprehensive study on the issue of setting an international minimum for criminal responsibility, states that while it "may not be the greatest challenge in juvenile justice or for children's rights around the world...(it is) consistently salient and controversial"(Cipriani, 2009:xiv). The reason identified for not setting a minimum age limit when deliberating both the Beijing Rules and the UNCRC was because age of maturity is loaded with cultural relevance and traditional sensitivities. The UN Seventh Congress acknowledged that children could not be considered to have criminal capacity from infancy (UN Seventh Congress: 9). Beyond this, the setting of the minimum age limit became one for individual states to decide on.

Setting the minimum age for criminal capacity is important for determining how the state will respond to children who offend, particularly in relation to state intervention along the 'welfare-justice' continuum (Cipriani, 2009). A possible consequence of setting the minimum 
age of criminal capacity too high (for example between the ages of 16-18) is that justice provisions, risk getting ignored. This can result in higher levels of state intervention, including disproportionate amounts of institutionalisation in relation to the offence (SlothNielsen, 2001:141). It also limits children's ability to be held to account and to take responsibility for their actions (Cipriani, 2009). Nevertheless, most nations agree that children under a certain age lack the maturity and moral development to have criminal capacity. Roman law which has historically influenced setting the minimum age of criminal capacity in a number of western jurisdictions suggests that there is an age under which a child cannot be held criminally responsible, referred to as doli incapax.

Due to the uncertainty around setting a minimum age of criminal responsibility, many countries have opted for a transitional period between childhood and adolescence where a child's criminal capacity needs to be determined in order to consider how to respond to their behaviour. Consideration for children in the transitional age bracket is referred to as the rebuttable principle. In their general comment related to children's rights in juvenile justice, the UN Committee on the Rights of the Child (2007) noted that some countries set two minimum age limits for determining criminal capacity. However, the Committee further recognised the risks in having a transitional period where a child's criminal capacity needs to be established. Skelton and Badenhorst (2011:6) explained that this can lead "to children being treated differently according to their maturity and the nature and quality of the rebuttal evidence adduced by the prosecution".

In 2007 the UN Committee on the Rights of the Child highlighted the differences in minimum age limits being applied internationally, which ranged between $7-16$ years old. The Committee noted: "In the light of this wide range of minimum ages for criminal responsibility the Committee feels that there is a need to provide the States parties with clear guidance and recommendations regarding the minimum age of criminal responsibility". As a result of their deliberations, the Committee recommended that 12 years of age be considered the minimum age of criminal capacity and encouraged nations with a minimum age below 12 to increase it". ${ }^{276}$ It further noted that there should be no exceptions to this minimum age, even in cases of very serious offending by children under the age of 12 .

\footnotetext{
${ }^{276}$ The Committee still noted that 12 years old was to be considered the starting point for a minimum age of criminal capacity and that additional increase would still be commendable. They therefore did not recommend lowering the age of criminal capacity to 12 if it had already been set higher.
} 
In developing its new youth justice legislation in the 1980s, New Zealand did not rely on international discussions on setting age limits for youth justice which set the upper age limit at 18 years. Instead policy makers chose to maintain the existing age brackets that had been set in the development of the Children and Young Persons Act of 1974. These defined 'children' as people under the age of 14 years, and 'young persons' as people between the ages of 14 to 17 years. This division provides an automatic difference in the way these two groups are treated under the CYPF Act, which only deals with youth justice matters for children and young people up to the age of 17. Therefore, in New Zealand, there is no age bracket for a rebuttable principle in which criminal capacity needs to be determined. However, there is provision for children between 10 to 14 years to be sentenced in the High Court for murder and manslaughter, without an assessment on their criminal capacity in relation to their age. ${ }^{277}$ Therefore, while New Zealand's lower age limit for criminal capacity is technically within the acceptable range by revised international standards, sentencing of children between the ages of 10 to 14 in the High Court for serious offences without consideration for their criminal capacity disregards the recommendations made by the United Nations Committee on the Rights of the Child in General Comment No.10 in 2007. This is further reinforced by New Zealand's decision in 2010 to amend its youth justice legislation to extend the range of offences for which children between the ages of 12 and 13 can appear before the youth court. The fluidity of New Zealand's provisions for responding to children and young people who offend in terms of shifting them between jurisdictions and courts essentially undermines children's rights that should apply up to the age of 18 years. New Zealand has continued to avoid aligning its youth justice system to apply to children up to the age of 18, even after ratifying the UNCRC. Nevertheless, in a conference titled 'Addressing the Underlying Causes of Offending: What is the Evidence' hosted by Victoria University in Wellington in February 2009, Ludbrook reminded the audience, that irrespective of what jurisdiction children under the age of 18 years are subject to, the same international youth justice principles in the UNCRC should apply (as noted in the Juvenile Justice Toolkit).

In New Zealand, compliance with international standards for children and young people in conflict with the law tends to become more blurry when they are transitioned to the District or High Court for sentencing. The irony is that these are likely to be children and young people who have committed the most serious or most frequent offending and are likely to

\footnotetext{
${ }^{277}$ As noted in Chapter 12, in 2010, the New Zealand Government passed The Children, Young Persons and their Families (Youth Courts Jurisdiction and Orders) Amendment Act of 2010 which extended the range of sentences 12 and 13 years old can appear before the Youth Court beyond murder and manslaughter.
} 
require more intensive age-appropriate interventions and community support to assist with their reintegration and rehabilitation. However, the adult jurisdiction has been limited in its ability to respond to the needs of children and young people in conflict with the law ${ }^{278}$ It also means in effect that New Zealand runs a bifurcated youth justice system, whereby children and young people are treated by two different jurisdictions depending on the seriousness of their offending - something that South African law makers fought hard to prevent in their system in order to ensure that children's rights principles could apply to all children in their youth justice system. Judge Becroft noted that New Zealand's reluctance to change its youth justice legislation to comply with the international standards for age is sufficient evidence of the country's limited commitment to meeting these standards:

I think what that indicates is that when push comes to shove, we don't take those international standards seriously enough...if we really, really were taking UNCRC remotely seriously, we would have changed that age a long time ago...You see, we allow under 17 year old New Zealand females to go straight to an adult prison if they're sentenced to prison as I sentenced one to $21 / 2$ years last week. We breach UNCRC there. The age mixing is breached. Several things we do that I think are unacceptable. They are not young adults, and you can't say adult crime results in adult time, because they are not adults. So it would be better if there were a specialist court that takes all those things into account - takes into account how young people straddle the young child and the adult, that it's developmentally work in progress, different interventions are required, there's still a chance to bring about change. I think it's more likely a specialist court is going to get the balance right. I think the history of transferring young people to the adult court has shown we haven't got it right, and we've just adopted a junior adult approach, which I think will achieve nothing actually. I think a fully functioning youth court with full jurisdiction would offer much greater chances of bringing a rehabilitated young person for life in the adult world. ${ }^{279}$

\footnotetext{
${ }^{278}$ At the time of writing, New Zealand's Department of Corrections is developing strategies and operational policy to better respond to the needs of youth up to the age of 25 both in prison and in the community. ${ }_{279}$ Interview with Judge Becroft dated 24 November 2009.
} 
Compared to New Zealand, the UNCRC was able to provide a universal benchmark for at least considering the upper age limit for its youth justice jurisdiction in South Africa. SlothNielsen explained that ensuring South Africa's child justice legislation applied to all people up to the age of 18 , in line with the UNCRC, was a core principle for SALRC. She noted that at the heart of the law-making process was the fact that children under the age of 18 should be treated differently to adults by virtue of their age:

When you are talking about values, I think looking at corporal punishment one starts out with the value of human dignity. But more importantly, maybe at the core, what happened between 1994 and 1999 was slow realisation of the Constitutional rule, coming from the CRC, that children under 18 are different. That there is now a dividing line and that 'under 18' is something different to 'over 18'. Once you have established that as a principle, then it gives you a lot of leeway to start experimenting and playing around, because people already believe that (children) are not the same as adults. They warrant, not necessarily lighter treatment - but you've got more malleable, growing adolescents that have got more life opportunities at stake, and with whom you can achieve more. That to me is a very fundamental point. In international terms now it's about the child's evolving capacities. ${ }^{280}$

Setting the minimum age in South Africa however, proved to be more of a challenge. When South Africa was deciding on a minimum age of criminal capacity, existing legal provisions set the age at seven years (one of the youngest in the western world) (South African Law Reform Commission, 1997), with a rebuttable principle applying up to14 years. The SALRC quickly agreed that the minimum age needed to be raised. Ten years old was considered as a starting point for increasing the minimum age of criminal capacity. Despite some discussion to increase it further, 10 years old was the age that was settled on by the government and passed into law. The rebuttable principle was retained for children between the ages of 10 and 14. Any person above the age of 14 was considered to have "full criminal capacity" (Gallinetti, 2009:17-19). ${ }^{281}$ Skelton and Badenhorst (2011) explain that South Africa had been urged to consider raising its minimum age of criminal capacity to 12 years by the United

\footnotetext{
${ }^{280}$ Interview with Prof Julia Sloth-Nielsen dated 16 October 2009.

${ }^{281}$ As noted above, any person below the age of 18 is referred to as a child, rather than making any distinction between 'children' and 'youth' or 'young persons'.
} 
Nations Committee on the Rights of the Child as early as 2000 during the initial law reform process. While the Child Justice Bill of 2002 did not propose as bold a leap in changing the minimum age of criminal capacity, strong and convincing proposals for this case were made during the submissions to Parliament in 2008. The Portfolio Committee members were reportedly interested in the suggestion to raise the minimum age of criminal responsibility to 12 years, but lacked the statistical data to convince them to take this step. As a result, they accepted the proposal for the minimum age to be raised from 7 to 10 years and to retain the rebuttable principle between 10 to 14 years. However, they also agreed to include the provision for the minimum age issue to be reviewed within five years of the legislation coming into force (Skelton and Badenhorst, 2011:32). As a result, South Africa did not comply with the more recently recommended lower age limit set by the Committee on the Rights of the Child, choosing to take a more cautious, evidence-based approach than the more principled approach they took when setting their upper age limit.

The challenge of the rebuttable principle is in trying to determine the criminal capacity for children who fall within that age bracket. Prior to the CJA, the process left little opportunity for these children to be found criminally responsible (South African Law Commission, 1997) as it amounted to a judge asking a parent if their child knew right from wrong. Not many parents would admit to their child not having developed this moral conscience as this could potentially reflect poorly on them. Therefore, only a few children were protected by this provision. Skelton and Badenhorst (2011:15) criticised this former approach to determining a child's criminal capacity, noting: "This practice was unfair because it created the risk that uneducated persons believed that they were giving evidence in mitigation and thereby assisting the child offender". Gallinetti explained that the issue of determining criminal capacity was one of the key reasons she was attracted to the child justice movement in South Africa. She recalled:

The thing that jumped out at me was the issue of age and criminal capacity - the fact that with the rebuttable presumption when the child's below 14 but above the age of 7 , one of the reasons that the project committee wanted that there be a proper assessment of age and criminal capacity was because: What does the state do? It calls mom, and says to mom: 'Does your child know (right from wrong)?' That's exactly what would happen in practice and it would be so frustrating, because of course she's not going to 
lie and say that she didn't teach her child the difference between right and wrong! So it was exactly because of those types of things that when I then started engaging with the Bill, it all just came together and made sense at the end of the day. ${ }^{282}$

The decision to retain the rebuttable principle in the CJA rather than setting a minimum age which applied to all children was in part to recognise South Africa's diverse social, environmental and cultural circumstances which could influence the speed of maturation. Protections were therefore built into the legislation for children between the ages of 10 to 14 . These children can only be prosecuted after the prosecutor has taken into account the following factors:

- the educational level, cognitive ability, domestic and environmental circumstances and the age of maturity of the child;

- the nature and seriousness of the alleged offence;

- the probation officer's assessment report;

- the impact of the alleged offence on any victim;

- the interests of the community;

- the prospects of establishing criminal capacity;

- the appropriateness of diversion; and

- any other relevant factor

(Gallinetti, 2009:18-19)

The purpose of the probation officer's assessment report includes requirements to determine the child's age as well as the child's criminal capacity and intent.

As noted, the UNCRC provides guidance on the upper age to which the principles were intended to universally apply. However, the discussion on determining the domestic age of criminal capacity, and on how the treatment of children in conflict with the law can depend on their age and the seriousness of their offending, exposes how a country's treatment of the age issue becomes a reflection of the country's commitment to international standards for youth justice. Both the bifurcated approach in New Zealand and the rebuttable principle in South Africa indicate that children are not all viewed as having equal rights, but that still in

${ }^{282}$ Interview with Dr Jacqui Gallinetti dated 15 October 2009. 
both countries individual rights are subject to the discretion of the judiciary, particularly for children between the ages of 10 - 14 (i.e. the youngest children to be able to enter the youth justice system in both countries). While children and young people should receive different responses for their offending given the need to take into account the specific circumstances and the seriousness of the offending on a case by case basis, both countries need to work on fairness of their overall provisions for responding to children and young people in conflict with the law if they want to align with the intentions of the international standards for youth justice.

\section{Due process}

Article 40 of the UNCRC covers general criminal procedure as well as suitable outcomes for children in conflict with the law. This includes treating these children:
...in a manner consistent with the promotion of the child's sense of dignity
and worth, which reinforces the child's respect for the human rights and
fundamental freedoms of others and which takes into account the child's age
and the desirability of promoting the child's reintegration and the child's
assuming a constructive role in society.

(United Nations Convention on the Rights of the Child, 1989)

While seeking to uphold children's dignity in youth justice procedures and seeking ways to divert children, Article 40 makes specific provision for upholding due process in criminal proceedings. The importance of due process in juvenile justice proceedings was highlighted in the case of Gerald Gault (among others around the same time), a fifteen year old boy from Arizona in the United States of America. Gerald Gault was accused of making obscene phone calls (In Re Gault et al, 1967). Given the speed of the proceedings, he had no counsel present and no opportunity was accorded to cross examine the complainant. The state in its position of parens patria ${ }^{283}$ declared Gerald Gault a 'juvenile delinquent' and committed him to six years in a state industrial school. It was noted that the same charge would have received a maximum penalty of two months imprisonment for an adult at the time. Gault's lawyer took the matter to the U.S Supreme Court highlighting the lack of due process when committing a juvenile to an institution. A key problem was that in adopting the position of parens patria,

\footnotetext{
283 “"The state's authority to act in place of parents for the resolution of individual cases, which often involved questions of property or guardianship...when parents were unable or unwilling-as deemed by the state itself-to provide acceptable care" (Cipriani, 2009: 5-6).
} 
the state had effectively turned matters pertaining to juvenile delinquency into civil matters rather than criminal matters (Cipriani, 2009:7). While the intention was to protect children in trouble with the law, Gerald Gault's case showed that without consideration for due process afforded in adult criminal proceedings, outcomes for youth can become more restrictive and ultimately punitive than for adults. As a result of this case, Justice Fortas (1967) wrote: "Juvenile Court history has again demonstrated that unbridled discretion, however benevolently motivated, is frequently a poor substitute for principle and procedure". In his decision, Judge Fortas also made it clear that allowing young offenders due process does not undermine other provisions for protections accorded to children who commit an offence, and acknowledged the ongoing importance of these provisions.

The Gerald Gault case and similar cases around the same time accelerated the debate to separate justice and welfare responses to children in conflict with the law in the western world. This meant that new emphasis was placed on the justice model with processes and consequences that were focused on and proportionate to the offence, rather than on the separate welfare needs of the child. This was not to say that children who committed offences did not have welfare needs or that these needs should be ignored, but rather that if these needs existed they should be considered and addressed separately. This was to ensure that due process safeguards afforded to adults, such as being considered innocent until proven guilty, the right to legal representation and consequences proportionate to the offence, would be incorporated into child justice proceedings to avoid unnecessary or excessive welfare responses to some children.

Prior to the CYPF Act, young people in conflict with the law in New Zealand were dealt with within the welfare system. This meant that there were no provisions for due process to ensure that youth were treated fairly in the system and that the response to their behaviour was proportionate to the offence. New Zealand decided to include the justice model into its youth justice legislation after Doolan observed this approach in practice during his visits to Canada, the United States and the United Kingdom in the late 1980s. As discussed in Chapter 5, he was able to convince the youth justice working group to rely on these principles rather than re-applying a welfare approach to the design of the new youth justice system. Judge Brown (1992:7) noted that the intention of the new law was to ensure that "whether a child or young person needs care or protection is a separate issue from whether or not he or she has committed offences against the law. Offending behaviour should be dealt with as just that, not as something else". Therefore, as New Zealand moved towards embedding a justice 
approach to dealing with children in conflict with the law, due process became an important feature in the new youth justice system.

By the time SALRC was drafting up the CJA in South Africa, due process in child justice proceedings was recognised as a salient right for children in the criminal justice system. South African law makers viewed due process as an important inclusion in the child justice legislation, particularly given South Africa's history of detaining children without trial, most notably during the state of emergency in the 1980s. Therefore, it was essential that children were given the right to a fair trial, that they were innocent until proven guilty and that the response was proportionate to the offence.

\section{Diverting children and young people from criminal proceedings}

Article 37 of the UNCRC deals specifically with the conditions around treatment and detention of children in conflict with the law, emphasising that detention should only be used as a "measure of last resort for the shortest appropriate period of time". It also reinforces the separation of children from adults in detention facilities. While it is accepted that there are times when depriving children of their liberty is required to keep communities safe from offenders capable of committing very serious crimes, (including rape and murder), UNICEF (1998) points out that that this should not be at the cost of upholding their rights as children up until the age of 18. This matter was specifically discussed in the United Nations Eighth Congress on the Prevention of Crime and Treatment of Offenders held in Havana, Cuba in 1990. Although this Congress was tasked with reviewing the implementation of the Beijing Rules, it resulted in the setting up of a new set of guidelines around the conditions of children in detention facilities. These are the United Nations Rules for Protection of Juveniles Deprived of their Liberty or 'Havana Rules', adopted by the United Nations in December 1990. These rules aim to ensure that children deprived of their liberty are treated in conditions that uphold their dignity and wellbeing, as well as providing for their development and possibilities for social reintegration.

International research into the detention for children and young people around the world has continuously identified inhumane treatment and conditions for children in custody which has resulted in stronger lobbies for alternative, community-based measures. One significant example is from Defence for Children International (DCI), an independent non-governmental organisation established in 1979, the Year of the Child as declared by the United Nations. Since then, DCI has been instrumental in promoting and influencing the implementation of 
children's rights around the world. Over the years, they have shown particular interest in the rights of children in conflict with the law, conducting several investigations in different countries on the topic of juvenile detention. In 2003 they published a report called 'Kids behind bars - a study on children in conflict with the law: Towards prevention, stopping incarceration and meeting international standards', which they presented to the UN Secretary General in 2005. One of the key findings from their investigations was that the principle of using detention as a last resort for the shortest appropriate period of time was often ignored: "Many (children) have committed no crime at all, such as street children, political prisoners, refugees and asylum seekers, children with mental disabilities and others detained without judicial process" (Defence for Children International, 2003). This study resulted in DCI launching a global campaign called 'No kids behind bars' to invigorate and promote the provisions of the UNCRC which calls for the prioritising of alternatives to detention for children in conflict with the law. Alternative dispositions identified in Article 40 of the UNCRC include:

Care, guidance and supervision orders, counselling, probation, foster care, education and vocational training programmes and other alternatives to institutional care shall be available to ensure that children are dealt with in a manner appropriate to their wellbeing and proportionate both to their circumstances and the offence.

According to UNICEF's Child Development Centre (1998:4) international standards for diversion are not intended to represent a "lenient" approach to dealing with the problem of youth offending. Instead they were designed help children and young people understand the impact of their offending and to develop pro-social skills from this experience. Encouraging social reintegration as part of the process is significant in reinforcing the role of the family and the community in taking responsibility in responding to children who offend. Diversion procedures should be designed to promote the best interests of the child by "avoiding the negative effects of juvenile justice proceedings, including stigma of conviction and sentence" (Van Bueren, 1995:174). They should hold children and young people to account, respond to the needs of victims' to repair the harm, prevent re-offending and promote public safety. They should also be responsive and flexible, providing scope for creative solutions which ideally involve families and the community. However, in trying to avoid the formal justice 
system, it is important that any diverted course of action does not result in a stigmatising and damaging outcome for the child (Van Bueren, 1995:180).

New Zealand's youth justice system was designed to reduce the number of children coming to court and to seek every opportunity to include families in making decisions around how to respond to offending by children and young people as well as to support their reintegration. This process was primarily made possible through the activities of the police youth aid division which provided a number of options to divert youth from the criminal justice system. In more serious cases, young people could be referred for an FGC either via police youth aid or the Youth Court Judge. As a young lawyer at the Community Law Centre in Mangere, South Auckland, Judge Becroft recalled noticing the immediate drop in the numbers of children appearing before the courts soon after the CYPF Act came into force. He stated:

I remember Judge Brown phoning me out of the blue, and he said Andrew, given your experience, you're going to see a difference. And I said 'A difference! We're just not seeing kids in court anymore! He said 'Good, good my boy.' That is the single biggest change I saw. ${ }^{284}$

According to the Ministry of Justice report published in March 2012, between 2001 and 2010 in New Zealand $80 \%$ of cases were dealt with outside of court through the use of warnings, diversion programmes and FGCs. However, according to this report, while the total number of apprehensions dropped over this period for all racial groups, the greatest decline in apprehensions was for Caucasians. Māori represented the highest number of apprehensions overall and their apprehension rate did not decline after 2006 (Ministry of Justice, 2012:6). These statistics illustrate that while the measures New Zealand put in place in 1989 to limit children and young persons' exposure to the criminal justice system have stood the test of time, there are still concerns that Māori remain disadvantaged in the system. Therefore, the youth justice provisions in the CYPF Act have not yet been able to adequately address the racial concerns around disparity and disproportionate representation of Māori children and young people in New Zealand's youth justice system, first brought to light by ACORD in the early 1980s.

Creating opportunities to divert children from the criminal justice system, particularly court processes and detention, was central to youth justice transformation in South Africa. The

${ }^{284}$ Interview with Judge Becroft dated 24 November 2009. 
intention was to develop diversion options that would hold children to account, encourage them to take responsibility for their actions and foster their positive reintegration into the community. These principles were to apply to all children, irrespective of the nature of their offending. Muntingh referred to a persuasive submission on the Bill made to the Portfolio Committee by Joan Van Niekerk from South Africa's Childline who had frequent contact with child victims of crime and the impact of offending against them, noting:
I remember that the particular thing that swayed the Committee was a submission by Joan Van Niekerk. Without much empirical proof, she said It is better to have sex offenders in a diversion programme, because then you can bring the services to them. If you want to prosecute and convict them, your chances of a conviction are so slim that that person is not going to receive any services'. I think that swayed many of the MP's or the committee members, saying 'Well you know, we do actually need to consider everybody for diversion. Even if it's a serious offence, it would be better if they do get some services. ${ }^{285}$

This submission generated interest among key members of the Portfolio Committee. It encouraged them to consider the advantages of providing children with programmes which could help them understand the impact of their offending behaviour and learn skills to avoid the same type of behaviour in the future. Muntingh explained that the notion of diversion captured his interest as a result of his own experience of getting in trouble with the law as a teenager. ${ }^{286}$ To him, one of the key benefits of diversion was that young people could be spared a criminal record. He stated:

I get calls regularly from people saying, 'Listen when I was 15 or 16 or 21 I did something stupid and I applied for a job fifteen years later and I was kicked off because I have a criminal record'. I think that is a very real achievement of diversion, and that definitely maintained my interest in it. ${ }^{287}$

Once it was established that there would not be a bifurcated approach to dealing with children in the justice system, a range of diversion options were proposed (Wood, 2003). The SALRC were able to draw from several practical examples that had emerged from the IMC pilot

\footnotetext{
${ }^{285}$ Interview with Lukas Muntingh dated 1 October 2009.

286 Ibid

${ }^{287}$ Interview with Lukas Muntingh dated 1 October 2009.
} 
projects and NGOs like NICRO to support the development of clear and detailed procedures for a range of diversion options. Sloth-Nielsen reflected:

\section{There would be some substantive law in it like standards for diversion, but mainly it would describe a process that would ensure that as few children as possible went through the criminal justice system. ${ }^{288}$}

Children in South Africa whose criminal case has gone to trial still have the opportunity to be diverted from further criminal procedure, including detention, following a court order during a trial (Gallinetti, 2009:43). A presiding officer may decide to divert a matter at any point during a Child Justice Court trial. In these cases, the proceedings will stop to await the outcome of the diversion process. If the young offender fulfils the obligations of the diversion option, the trial will no longer proceed. If the diversion process is not successful, then "the case continues in the Child Justice Court and any acknowledgement of responsibility may be recorded as an admission for the purposes of the trial" (Gallinetti, 2009:52). This allows for diversion from court proceedings to occur at any time during the process until the child is found guilty at trial, at which point they are subject to court sentencing procedures.

The CJA introduced two levels of diversion, allowing for some distinction between diversion options for minor versus more serious offences. This broadened the scope for diverting children irrespective of the nature of their offending. The distinction between the levels of diversion is also made in terms of the timeframes for which a diversion option can be imposed. ${ }^{289}$ Level 1 diversion options include, for example, a formal caution (with or without conditions), writing a letter of apology to the victim, compensation or restitution for the offending, doing community work, attending an educational or therapeutic programme or a range of orders either encouraging certain behaviours such as attending school or spending time with the family or prohibiting certain behaviours such as associating with identified peers or visiting a particular location (Gallinetti, 2009:44). Level 2 diversion options could include any of the Level 1 options, as well as interventions designed to address the seriousness of the offending behaviour such as more intensive therapeutic programmes, some of which may include a residential component or stricter oversight by a probation officer (Gallinetti, 2009:44). Diversion was therefore made possible for all cases, including rape,

\footnotetext{
${ }^{288}$ Interview with Prof. Julia Sloth-Nielsen dated 16 October 2009.

${ }^{289}$ Level 1 diversion options can be imposed for up to 12 months for children below the age of 14 years and for up to 24 months for children above the age of 14. Level 2 diversion options can be imposed for up to 24 months for children under the age of 14 years and up to 48 months for children above the age of 14. (Section 53 of the Child Justice Act 2008)
} 
armed robbery and murder. However, in these very serious criminal cases, Skelton explained: "you have to have the Director of Public Prosecution sanctioning that, and the victim has to be consulted. It's a very high threshold, but nevertheless, it's possible". 290

Skelton recognised that some of the Level 2 provisions were the government's way of allaying concerns that diverting children from criminal procedure was a 'soft approach'. One example of this was the inclusion of the possibility a diversion programme lasting four years. Skelton viewed this as "unreasonable" 291 , stating:

The way we are interpreting that is you'd have an intensive period for six weeks or something, and then you have sort of follow up, getting less and less and less. Maybe one positive effect is that we would get more after care services, which at the moment are virtually non-existent. ${ }^{292}$

Skelton believed that this satisfied the government's need to be seen as 'tough on crime' and to create more rigid, bureaucratic procedures around diversion. ${ }^{293}$ Compromises were made on both sides to address each party's position. In the end, the provisions in the CJA aimed to ensure that the 'minimum standards applicable to diversion' are based on children's rights principles as well as consideration for restorative justice, with due consideration for victims being taken into account. ${ }^{294}$

Like Judge Becroft in New Zealand, Pinnock in South Africa recalled his experience of realising that diversion provisions in the CJA were taking effect:

I was talking to the head of the youth prison at Pollsmoor, the youth B prison. He was complaining to me and saying 'This place is not nice any more', and I said 'Why?' He said, 'Because there is nobody under 18 anymore. I used to really like working with kids, and now there's nobody under 18 anymore.' And I said 'Yes! That's fantastic!' - But he was quite cross.

A lot of 'awaiting trial' kids are just not going to prison anymore. They are going back to their families or going to some sort of place that is not a

\footnotetext{
${ }^{290}$ Interview with Dr Ann Skelton dated 29 September 2009.

291 Ibid

292 Ibid

293 Ibid

${ }^{294}$ Section 55 of the Child Justice Act 2008
} 
prison-certainly not a gang situation. So, slowly, slowly, the country is putting itself into the right space with regard to child justice. ${ }^{295}$

Reports on the first year of implementation of the CJA identified a significant drop in the numbers of children being held in custody awaiting trial. According to the South African Department of Justice and Constitutional Development's first annual report on the CJA (2011), there was a "decrease of just over nineteen per cent $(19,81 \%)$ " in the first year following the CJA coming into force. This drop in numbers of children being remanded in custody has been hailed as one of the main indicators of success in the implementation of the Act (South African Department of Justice and Constitutional Development, 2011:5). Interestingly, this same report also recognised a notable decline in the numbers of children being diverted. The report could not clearly identify the reasons for this drop in diversion numbers. Suggestions included the fact that less children were being arrested (possibly due to police uncertainty around their legislated responsibilities regarding arrest resulting in their reluctance to arrest children under the age of 18) as well as a decrease in the overall rates of offending by children during the Football World Cup in South Africa in 2010 (Badenhorst, 2011). However, as Badenhorst points out, the explanations have no evidence-base. As a result, the Director-General for Justice and Constitutional Development commissioned a study into the reasons for the decline in diversion rates in 2011 (South African Department of Justice and Constitutional Development, 2011; Badenhorst, 2011). ${ }^{296}$

One of the challenges both New Zealand and South Africa has faced in terms of increasing chances for diversion from the formal justice system is that in order for children to be diverted, they must admit responsibility for their offending. However, this can be difficult when weighed against the right to a fair trial, which can then draw out the child's exposure to criminal procedure and delay access to rehabilitation and reintegration programmes. As a result, a risk is that children are encouraged to admit responsibility to increase their chances of getting diverted. According to Skelton and Frank (2004:209), “The criminal justice system emphasis in due process rights is, however, a narrow construct of rights. It is possible to give up the right to be presumed innocent through acknowledging responsibility and retaining one's human rights".

\footnotetext{
${ }^{295}$ Interview with Don Pinnock dated 2 March 2011.

296 This report had not been finalised at the time of writing.
} 


\section{Monitoring international standards for youth justice}

The 'Guidelines for Action on Children in the Criminal Justice System Recommended by Economic and Social Council Resolution 1997/30 of 21 July 1997' state that their aim was: "To implement the Convention of the Rights of the Child and to pursue the goals set forth in the Convention with regard to children in the context of the administration of juvenile justice, as well as to use and apply the United Nations standards and norms in juvenile justice". In order to monitor compliance with the international standards for children's rights, the requirement to set up a United Nations Committee on the Rights of the Child was built into the Convention. This Committee consists of eighteen experts selected from a variety of nation states, but not representing their particular nation. State parties are obliged to provide reports to the Committee identifying the measures they propose to better uphold the principles of the Convention in their domestic policies. This initial report should be submitted within two years of ratifying the Convention, with progress reports submitted every five years thereafter. The Committee can in turn make recommendations on how to improve their implementation of the principles after considering the report. ${ }^{297}$

Although international instruments were developed to guide domestic application of juvenile justice, the United Nations found that most countries fell short of meeting the minimum requirements. Hence, in 2006, UNICEF developed the 'Manual for the Measurement of Juvenile Justice Indicators'. This manual identifies fifteen indicators to measure compliance with international standards for juvenile justice and provides guidance on how nation states can gather information on their current status in the treatment of children in conflict with the law. The indicators are aimed at providing a baseline as well as identifying targets and improvements both nationally and internationally.

As a result of these juvenile justice indicators, the United Nations also developed a toolkit to assist nations with the implementation of juvenile justice systems in line with the international frameworks. This toolkit asks a series of questions about how individual nations are performing in relation to youth justice matters. The development of both the juvenile justice indicators and the comprehensive toolkit suggests an increase in vigilance by the international committee monitoring the application of youth justice practice. Twenty years after the adoption of the UNCRC followed by ongoing monitoring and research into these matters, it appears that the international community has become better able to hone in on the

${ }^{297}$ Article 43 of the UNCRC 
key shortcomings and develop clearer measures for success and construct stronger mechanisms for identifying areas of improvement. While international oversight has helped to provide some guidelines for quantifying success in youth justice systems, innovations for community-based approaches as well as alternatives to criminal proceedings and detention have also helped provide better models of how different countries can meet these arguably more nebulous standards.

Policy makers in both New Zealand and South Africa believed that provisions for overseeing the application of the youth justice legislation should be included in law. The concept of a Children's Commissioner in New Zealand was initially built into Section 9 of the CYPF Act, initially established to oversee its implementation. It was intended to be a partly independent mechanism aimed at upholding children's interests and allaying the concerns around the community-based approach to addressing children either in need of care and protection or in the justice system. Hassall, who was appointed as the first Children's Commissioner after the passing of the CYPF Act, played a significant role in ensuring that consideration was given to the role of a children's commissioner while the CYPF Act was being developed. He explained he wrote a letter to Minister Cullen with this suggestion as a way to:

...calm some of the fears that had been expressed by many people that placing the disposition of children who had been abused and neglected in the hands of the families that had been responsible would leave children in the lurch. ${ }^{298}$

As a result of this letter, he was in vited to meet with the then Minister of Social Welfare and other senior members of the government to look at this possibility. Hassall noted that he took the initiative to do this stating:

I felt very strongly that here was a process barrelling on and, as has happened in so many spheres of activity, the very people that this was all about were not there at the table. So that was why I did it. ${ }^{299}$

Hassall acknowledged that he had been influenced by other models for upholding children's interests, most notably the Norwegian Children's Ombudsman, which he noted was the first example of this role in the western world, established in 1981. He explained that in his view,

\footnotetext{
${ }^{298}$ Interview with Dr Ian Hassall dated 2 February 2011.

${ }^{299}$ Ibid
} 
the key responsibility of the Children's Commissioner was to monitor the implementation of the Act and to be an advocate for children's rights and interests. He noted that while the word "advocate" was not specifically included in the legislation, it was included in the parliamentary debates, and was therefore in Hansard. Hassall noted that he was not only interested in the establishment of a Children's Commissioner, but also in ensuring the survival of this position. As such, he sought buy-in from what he referred to as 'constituencies'. He described the survival of the office as a sort of delicate balance between retaining government support while being upfront about children's needs and the demands of those representing and advocating on their behalf:

\begin{abstract}
You couldn't afford to be, nor do I think the public expected such an office to be simply a sort of tool or a branch of government, but nor could it be independent. It couldn't be seen as a launching pad for constant or repeated attacks on the government...Having said that, one of the things I really came to the conclusion about when I was a Children's Commissioner and towards the end of my tenure was that there was a need for a voice for children which was truly independent and critical. ${ }^{300}$
\end{abstract}

In 2003, New Zealand repealed the role of the Children's Commissioner from the CYPF Act, and introduced it within its own separate piece of legislation, the Children's Commissioners Act of 2003. While this legislation retained the Commissioner's function to monitor Child, Youth and Family activities, it specifically added to its purpose the following provisions: "to confer additional functions and powers on the Commissioner to give better effect in New Zealand to the United Nations Convention on the Rights of the Child" ${ }^{301}$ and "to require the Commissioner to have regard to the Convention when carrying out the Commissioner's functions and powers". ${ }^{302}$ By explicitly making this link between New Zealand's principal monitoring mechanisms for matters pertaining to children and young people and the UNCRC demonstrates some level of New Zealand's commitment to complying with the international standards. However, in practice, while the Office of the Children's Commission speaks out publicly against practices that concern them, it has not proven to have the level of authority that can sufficiently hold government agencies to account if they do not comply with the UNCRC. This tends to show that New Zealand's commitment to these international

\footnotetext{
${ }^{300}$ Interview with Dr Ian Hassall dated 2 February 2011.

${ }^{301}$ Section 3(c) of the Children's Commissioner Act 2003

${ }^{302}$ Section 3(d) of the Children's Commissioner Act 2003
} 
instruments remains one of convenience rather than out of a sense of moral obligation to universally binding principles.

In South Africa an inter-sectoral committee ${ }^{303}$ comprising the key government departments ${ }^{304}$ involved in the implementation of the provisions in the CJA was included in the legislation. The purpose of the committee is to oversee the implementation of the legislation and to ensure that the services are being delivered as intended. According to the Act, this Committee is required to meet "at least twice a year" 305 and to report to Cabinet on the progress being made in the respective departments prior to their meetings. ${ }^{306}$ Part of their responsibilities is to develop a 'national policy framework' outlining the implementation strategy, whereby they must prioritise the steps required by each department and to be able to measure and report on progress against these steps. ${ }^{307}$ A researcher for the Portfolio Committee of Justice and Constitutional Development who assisted in forwarding the development of the 2008 version of the CJA explained:

Parliament has an oversight role, so we will be asking the departments to report regularly, like how far it's got with the implementation plan and to give us feedback on how successful things are. We'll ask them to report quite regularly on that, but our role is quite limited. It's an oversight role...we can't order them to do the work. We can make recommendations. ${ }^{308}$

As in New Zealand, while this monitoring requirement has been built into legislation it does not have full independence. While a fully independent monitoring body was not legislated for, the Child Justice Alliance in South Africa has taken on an independent monitoring role to see that the implementation of the CJA is done in the spirit in which it was developed and that key role players and the community understand its purpose and principles. Gallinetti

\footnotetext{
${ }^{303}$ Sections 94-96 of the Child Justice Act 2008

${ }^{304}$ The Director-General: Justice and Constitutional Development, who is the chairperson of the Committee; the National Director of Public Prosecutions; the National Commissioner of the South African Police Service; the National Commissioner of Correctional Services; the Director-General: Social Development; the DirectorGeneral: Education; and the Director-General: Health. (Section 94(1) of the Child Justice Act 2008. Section 94(3) states that the members of the inter-sectoral committee can "designate a senior official of his or her Department as an alternate to attend a meeting of the Committee in his or her place.")

${ }^{305}$ Section 95(a) of the Child Justice Act 2008

${ }^{306}$ Section 95(b) of the Child Justice Act 2008

${ }^{307}$ Section 96 of the Child Justice Act 2008

${ }^{308}$ Interview with researcher for Portfolio Committee for Justice and Constitutional Development dated 8 October 2009
} 
explained how the Child Justice Alliance set up a monitoring tool to guide implementation of the CJA once it came into force:

We have developed a monitoring tool, and a little booklet on getting to know

the Child Justice Act...The monitoring tool is for when the Act comes into operation...It serves a dual purpose. On the one hand it's to alert government to problems with implementation, and the other is to allow us to continue to do some research on the ground - qualitative information coming up from the practitioners. ${ }^{309}$

The monitoring tool focuses on the "nine internationally accepted child justice indicators developed by UNICEF" (Child Justice Alliance (2010) Child Justice Act Monitoring Implementation Tool). These indicators are:

- children in detention;

- duration of detention;

- children coming into contact with the juvenile justice system;

- existence of a juvenile justice system;

- $\quad$ separation from adults;

- conditions for control of quality of services for children in detention;

- protection from torture, violence, abuse and exploitation;

- prevention; and

- after-care

Despite the development of this toolkit by the Child Justice Alliance, it appears that it has not been widely utilised since the CJA came into force on 1 April 2010. Therefore, it has not yet been able to generate adequate data on these nine aspects of implementation of the legislation to evaluate compliance in the key areas. ${ }^{310}$ Nevertheless, the Department of Justice and Constitutional Development released a report on the first year of implementation of the CJA after coming into force as required under Section 96 (3). This report notes the successes and challenges of implementing the procedures required by the CJA in the first year, reporting against the requirements of the Act, using government statistics.

\footnotetext{
${ }^{309}$ Interview with Dr Jacqui Gallinetti dated 15 October 2009.

${ }^{310}$ Email correspondence with the Child Justice Alliance dated 14 March 2012.
} 


\section{Conclusion}

In summary, the United Nations Sixth Congress on juvenile justice in 1980 provided the backdrop for developing youth justice systems internationally. These discussions concluded that increasing opportunities for children to remain in the community and to develop with the assistance of families and community members should be cornerstone to any youth justice system. This meant that measures had to be put in place to keep children out of the criminal justice system, to empower families and communities to reintegrate their children, to ensure due process protections were in place and to ensure that detention would only be used as a measure of last resort for the shortest period of time. These principles became fundamental to the Standard Minimum Rules for the Administration of Juvenile Justice (Beijing Rules) in 1985, and became part of the binding principles in the UNCRC in 1989. The standards were deliberately ambitious given the range of contexts they were trying to influence around the world. However, despite any prevailing national circumstances, the Beijing Rules were intended to provide a bottom line for the treatment of children in conflict with the law everywhere. According to the United Nations International Children's Fund (UNICEF) International Child Development Centre (1998:2):

\section{The paradox is graphically illustrated in the UN general assembly resolution adopting the 'Beijing Rules', which itself states that 'although such standards may seem difficult to achieve at present, in view of existing social, economic, cultural, political and legal conditions, they are} nevertheless intended to be attainable as a policy minimum.

The hope was to provide international standards that would help to keep nation states in check when administering youth justice practice. This included the basic requirements to promote children's development and social reintegration and to avoid the negative effects of detention, described at one point by the Congress as including: "physical and sexual abuse, emotional neglect, severe malnutrition, untreated physical and mental illness, suicide, psychological trauma and 'prisonisation'” (Seventh United Nations Congress:13).

The influence of international standards for children's rights in the development of youth justice policy and legislation in South Africa and New Zealand largely depended on timing, both in terms of international developments as well as internal processes. New Zealand's adherence to international standards came about mostly by coincidence, whereas South 
Africa's came about by design. Either way, both countries agreed to the need to protect children and young people's vulnerability, particularly by maximising ways to divert them from formal criminal justice processes and ensure their reintegration into the community. Whether or not New Zealand and South Africa deliberately referred to these standards when developing their youth justice policies, the end legislative products are able to demonstrate both countries' overall commitment to these youth justice principles and they have both been internationally commended for this. However, both countries still fall short on delivering on these principles in practice. Given that there is no penalty for non-compliance with the binding principles, the risk is that they can easily be ignored if compliance seems too complicated, or if there is no domestic appetite to adhere to them. In New Zealand, it appears that increasing opportunities have been sought in recent times to be able to respond to children and young people with harsher penalties from a younger age. South Africa on the other hand is still faced with the lack of resources and major socio-economic stressors which undermine adherence with the international standards as intended in the legislation.

Nevertheless, the international standards for youth justice will continue to be monitored and should still serve as benchmarks to strive towards in order to best support children and young people's development and to provide the best opportunities to prepare them for a future outside of the criminal justice system. 


\title{
Chapter 8
}

\section{Restorative justice principles in New Zealand and South Africa's youth justice systems}

\author{
I learned that restorative justice begins with respect, that it asks for respect \\ and recognition of our common humanity and that it challenges us to \\ understand and stay true to its philosophy and principles.
}

Wonshe (2004:254)

Restorative justice is often described as a key feature in both New Zealand and South Africa's youth justice systems. Given some of the more general restorative practices happening in both New Zealand and South Africa at the time they were transforming their youth justice systems, it is perhaps of little surprise that restorative justice principles are evident in both countries' youth justice legislation. Both countries had been implementing processes to help address the social imbalances of the past and to make amends for the effects of unjust policies and practices on indigenous populations. In New Zealand, restorative practices were increasingly being exercised at a national level through the late 1970 s and ' 80 s to address social imbalances. The Waitangi Tribunals allowed Māori to express their grievances as a result of colonial rule since signing the Treaty of Waitangi, and to be compensated by the government following the Tribunal process. Hicky (2007: 222) posits:

...that although the resolution of historical Treaty grievances in New Zealand is commonly termed 'settlement', the established settlement framework and negotiation process have strong elements of a restorative justice approach. The result is a reparation model that aims to achieve some level of reconciliation between the Crown and Māori and the descendants of settlers and tangata whenua.

In a speech at a restorative justice seminar in March 2010, Honourable Tariana Turia, the coleader of New Zealand's Māori Party, referred to the Treaty settlements as "the ultimate experience of restorative justice". 
Around the time of the initial drafting of youth justice legislation in South Africa, the country was also going through a national process of healing following the end of apartheid. This was embodied in an institution called the Truth and Reconciliation Commission (TRC). The TRC was set up by the Government of National Unity ${ }^{311}$ to provide a forum for victims and perpetrators to tell stories about their experiences of human rights violations and atrocities in South Africa. Three committees were set up under the TRC: the Human Rights Violation Committee, and the Reparation and Rehabilitation Committee (jointly responsible for identifying victims, establishing the nature of their violations and their resulting needs, and providing reparative and rehabilitative assistance) and the Amnesty Committee, set up for perpetrators to give full and frank admissions of their role in administering the violations as a function of political activity, either in upholding or opposing the apartheid system. The objective was that following an honest disclosure of accounts, these perpetrators could apply for amnesty from prosecution (Maepa, 1998:67). Volume 1 of the Truth and Reconciliation Commission of South Africa Report (1998:68) notes that one of the four key tasks of the process was: "The restoration of the human and civil dignity of victims of gross human rights violations through testimony and recommendations to the President concerning reparations for victim(s)". The principles of reparation for harm, and restoration of human dignity underpinning Waitangi Tribunals in New Zealand and the Truth and Reconciliation Commission in South Africa, have been referred to as examples of restorative justice aimed at national healing. As the needs and voices of disadvantaged families and communities in both countries became increasingly apparent, this thesis finds that they filtered into the psyches of the policy makers and gave direction to the strategies for responding to children in conflict with the law.

This chapter provides a theoretical framework for restorative justice, looking at how it is defined, and some of the opportunities and challenges the approach presents in practice. It discusses how restorative justice principles have increasingly been incorporated into youth justice practices internationally. How these principles are reflected in New Zealand and South Africa's youth justice systems will be specifically examined.

\section{Defining restorative justice}

According to Maxwell (in Maxwell and Liu, 2007:6), "the core aims of restorative justice are to repair the damage created by criminal offending and restore the balance of relationships

${ }^{311}$ Name given to the first post-apartheid government in South Africa 
within the society". This usually occurs through the participation those "affected by the offending" (Maxwell in Maxwell and Liu, 2007:6) (i.e. victims, perpetrators and members of the community) (Zehr, 2002), which encourages offenders to acknowledge and make amends for the harm. Restorative justice further aims to support the reintegration of all parties following the offence. According to Mika and Zehr (in Zehr, 2002:41) one of the "signposts" of restorative justice is to "show equal concern and commitment to victims and offenders, involving both of them in the process of justice".

The notion of restorative justice started attracting interest in the late 1980s around the time Howard Zehr published his book: Changing lenses: A new focus for crime and punishment (1989) in which he contrasted the restorative justice paradigm with retributive criminal justice systems. He noted that although "both retribution and restitution have to do with righting the balance... restitution is a more concrete way to restore equity" (Zehr, 1989:193). Zehr explains that the extent to which justice processes can be termed 'restorative justice' falls on a continuum which includes, for example, aspects of participation and ultimate decision-making by key participants, offenders taking responsibility for their actions, the nature of the restitution and how it addresses identified harms (Zehr, 2007).

\section{Involving families and communities in restorative justice processes}

While victims and offenders are central to restorative justice processes, restorative justice accounts for the ripple effects of criminal behaviour, and its impact on others close to both the victim and the offender, such as families. Therefore, families of offenders (for example) can also be held to account for the offender's criminal actions and contribute to the process of compensating the victim (and, where relevant, the victim's family).

The need for restorative justice processes to address wider family and community issues depends on the factors that have contributed to the offence. These can also be rooted in entrenched social, political and economic disadvantage (Toews and Katounas, 2004; Lofton, 2004). According to Napoleon (2004), families and communities should consider how they have contributed to criminal behaviour by their children and young people. This approach decompartmentalises the static statuses of the 'victim', 'perpetrator' and respective support people and creates a more fluid space whereby the needs of all participants are acknowledged and considered important to address in order to promote healing and repair. This is particularly significant for children and youth who offend as holistic restorative justice processes can expose shortcomings in their care and protection as well as gaps in their social 
and moral development. At the same time it can provide a forum for families and communities to consider how best to assist their reintegration. This is a key consideration in the Beijing Rules which states that "Juvenile justice shall be conceived as an integral part of the national development process of each country, within a comprehensive framework of social justice for all juveniles, thus at the same time, contributing to the protection of the young and the maintenance of a peaceful order in society". (Beijing Rules - Fundamental Principle 1.4)

Holding families or communities to account for children and young persons' offending is more common in cases where families are still considered responsible for their moral development. At the same time, children and young people are expected to take responsibility for their actions and participate in the restorative justice process according to their evolving capacities. ${ }^{312}$ Witnessing the emotional and physical impact of their behaviour on their families and victims is considered important in order to begin the process of restoration. If children and young people do not take responsibility for their actions or lack the capacity or capability to do so, the ability for offenders to repair the harm is likely to be diminished. This in turn impacts on the integrity of the restorative justice process.

John Braithwaite questioned the role of reintegrative shaming as a response to criminal behaviour in his book Crime, Punishment, Shame and Reintegration (1989). He was interested in whether shaming contributes to moral development. He found that processes of shaming and reintegration are closely linked with an individual's relationships with family, friends and the greater community. He identified that one's sense of connection to their social network influences the ability to understand the impact of their offending on others and feel shame as a consequence. He stated that "individuals are more susceptible to shaming when they are enmeshed in multiple relationships of interdependency" (Braithwaite, 1989:14). Shaming without reintegration however can make individuals feel isolated and rejected, leading them to gravitate towards similarly socially outcast groups, potentially resulting in further harmful behaviour. Tasler in Mays (1972) considered this dynamic within the framework of the social learning theory. He observed:

The threat of withdrawing approval will only evoke fear if the child has learned to rely upon and to value his parent's goodwill... the contrast between the ordinary enjoyment of their approval and the distress of being

${ }^{312}$ As provided in the UNCRC and the Beijing Rules 
temporarily out of favour is essential; if the child is constantly fearful and insecure in his relationship with his parents, the withdrawal of approval technique will not succeed in establishing a specific avoidance response. (Tasler, 1972:144)

Including shaming in the response to criminal behaviour has been criticised for the potential risks it carries (Zehr, 2002; Maxwell and Morris, 2004). These risks are linked to the negative psychological impact of stigmatising shaming, particularly given how difficult it can be to get reintegrative shaming "right" (Maxwell and Morris, 2004). Maxwell and Morris (2004) pointed out that the main drawback is in the way individuals experience shaming, whether stigmatising or reintegrative. They concluded that "a sense of being shamed, of being made to feel a bad person, that endures after decisions about how to repair damage are being made, is likely to contribute to further offending" (Maxwell and Morris in Zehr and Toews, 2004:139). They reiterated that the role of the family should primarily be to support and to encourage young people to take responsibility for their actions and to repair the harm rather than bringing shame into the process.

\section{Accounting for diversity and power imbalances}

Restorative justice philosophy aims to minimise the role of the state, experts and professionals in order to allow for spontaneous and organic processes to evolve during the encounter between the key participants (Sawin and Zehr in Johnstone and Van Ness, 2007:53). Therefore, restorative justice processes and outcomes should be guided by the unique experience of the participants, their interaction and shared interpretation of the event, and agreement on the most useful consequences. This encourages participants to "own and take responsibility for the decision-making process" (Bazemore and Bell, 2004: 122). The approach permits diversity among participants, including cultural diversity, in ways that more traditional western court systems have generally avoided. Although allowing for diversity may be of advantage in multi-cultural societies, there can be some risks if the process is not well managed. Depending on the broader social context in which restorative justice processes emerge, certain inherent socio-political, cultural, racial, status or economic power imbalances may create an uncomfortable and debilitating sub-text to restorative justice interactions. While the restorative justice process is designed to promote healing, some participants may start out with negative views based on nature of the participants, i.e. victims and offenders (Warner-Roberts, 2004:243). Some victims may feel overpowered by the presence of the 
offender who violated them, and some offenders may feel overwhelmed by victims confronting them and influencing decision-making about appropriate outcomes to make amends for their offending. These perceptions can become even more pronounced in youth justice cases. Youth may become more acutely aware of their social status as minors when faced with having to take responsibility for their actions against adult victims. In turn, victims of youth offending may feel intimidated by the presence of callous youth or overbearing or protective parents of an offender (Akester, 2003).

Even in situations where power imbalances per se are not of particular significance, there could be well-meaning symbolic cultural gestures introduced by one group of participants aimed at aiding the healing process, which may be misunderstood or shunned by another party, thereby increasing the rift and damaging the delicate repair process (Umbreit and Coates, 2000). It is equally important that cultural values and beliefs are not presupposed or assumed by those responsible for organising and facilitating the process. Boyack et al (2004:275) caution that, given the uniqueness of each restorative justice process depending on individual experiences and the exchange between participants, restorative justice processes "cannot be expected to meet all the personal or collective needs of those engaged in it". This emphasises the need for participants to be well informed about the purpose and process in advance to avoid setting unrealistic expectations.

Given the potential for damage to participants in emotionally charged restorative justice settings, the idea of a neutral person to facilitate the process is considered valuable, particularly in preparing participants and making them feel safe during the process (Akester, 2003; Van Ness et al. 2001:15). In order to address the complex needs and sensitivities that characterise a restorative justice encounter, facilitators need to possess a particular set of skills and qualities. Ideally they should be able to approach the process objectively and with an open mind, allowing for the exchange to unfold naturally, without being stifling, opinionated, or imposing. At the same time, they should enable the process to reach the intended outcome of restoration and repairing the harm (Umbreit and Coates, 2000; Dumortier, 2000). One of the main benefits of having a neutral mediator or facilitator is to provide safeguards in a setting where emotions are raw and tempers can flare, while still enabling a genuine experience (Akester, 2003). In their research into the effectiveness of FGCs in New Zealand, Maxwell et al (2004) found that potential tensions between participants were generally well managed by skilled youth justice coordinators, who mitigated concerns around power imbalances. They found that "many coordinators were 
successful in assisting victims to vent their anger, families to accept what the victim was saying and both parties to move on to a constructive approach to repairing the harm" (Maxwell et al,2004: 289).

In some indigenous practices, Skelton (2007: 469-470) notes that "traditional arbitrators are appointed from within the community" and "there is no professional legal representation". McCold (1997) has questioned the benefits of having community representatives present or playing any active role in restorative justice forums. McCold (1997) believes there is a risk that these representatives could "display an attitude of moral superiority, which could disrupt the resolution process". However, it is noted that having selected community representatives present may not only be accepted but also expected in some communities, particularly where there is a high level of interconnectedness between community members and an understanding that the community leaders act in the greater good of the community as a whole.

\section{Government involvement and social transformation}

Communities that are used to relying on the state to address criminal matters may not easily accept a restorative justice model without the state maintaining some oversight. Therefore government involvement is evident in most criminal justice systems which have introduced restorative justice principles. Whether governments are willing to include restorative justice principles in their justice systems is therefore generally a top-down decision, even if the process aims to empower the participants. Although restorative justice processes have become increasingly common, many countries tend to impose bureaucratic structures around the proceedings, often at the expense of empowering the key participants (Sawin and Zehr in Johnstone and Van Ness, 2007:53). Furthermore, inclusion of restorative principles can be limited to, for example, courts accepting victim impact statements, courts ordering reparation as sanction or requiring the offender to write a letter of apology to the victim. However, even in processes where there are face to face encounters between victims, offenders and their supporters, many models will also determine which professionals should be present in the restorative justice process. While these professionals may be required to facilitate the process, sometimes other state officials may be present, such as police. In many cases, the matter is still prosecuted in court where the judge's responsibility is to consider any outcomes or recommendations from the restorative justice process in the sentencing decision (Akester, 2003). This removes the facility for participants to independently make decisions. 
Consequently, while some states are willing to include restorative justice principles in their justice systems, they are still reluctant to entirely relinquish control over criminal matters to those directly affected. This may due to the state's commitment to protecting the public and ensuring fairness in the justice system. In addition, most governments recognise that criminal justice and law enforcement are popular trump cards for political campaigning and therefore not easily abandoned by governments.

Skelton and Frank (2004:210) have suggested that "restorative justice theorists and practitioners may need to move beyond the focus on the individual and begin an evaluation of the rights of the individual within a more communitarian approach". Involving the community in restorative justice processes is based on the principle that if crime extends beyond those directly involved, the outcomes of the process have the potential to benefit the community more widely. Zehr and Toews (2004:380) posited that "without expanding the vision of restorative justice beyond the individual victim and the offender experience, the philosophy and its practice will have little impact on the creation of right relationships in the broader social context". These ideas have led to questions about whether restorative justice processes can provide a means or a platform for addressing broader social justice issues. Julich (2003) noted that restorative justice processes have the potential to contribute to social transformation. Mike Batley from the Restorative Justice Centre in South Africa believes that it is important to acknowledge community scepticism and anger when promoting restorative justice principles, and to explain how restorative justice approaches can help to address the wider social concerns. He stated:

I think that the question is how does it help in terms of safety? Obviously people feel very unsafe, and does it even address the need for safety? It doesn't specifically in the immediate sense. But if we're saying that restorative justice does look at the underlying issues, is connected to social justice dimensions, and you look at some of the research that shows that it does actually reduce repeat offending, then in a broad sense and in the longer term, it definitely helps us to build a safer society. ${ }^{313}$

While a number of successful restorative justice encounters and outcomes may help to address some aspects of social justice through the sum of their parts (Cunneen and White, 2002:383), Lofton (2004) cautions that it is simplistic to think that relying on individual

${ }^{313}$ Interview with Mike Batley dated 30 October 2010. 
processes will provide enough 'drops in the ocean' to result in any meaningful level of social transformation. In her view, "restorative justice offers no more than a compass on our journey to a healthy society" (Lofton, 2004:388), and those truly committed to social justice should take their pointers from the "restorative justice compass" and engage with the social engineers to try to effect change.

\section{Restorative justice approaches strengthen compliance with international standards for youth justice}

Restorative justice did not significantly influence the creation or development of international standards for youth justice (even though it was being discussed and debated separately at the time). Nevertheless, both restorative justice and youth justice standards were developed in the spirit of creating pathways that would minimise harm, promote responsibility, restitution and repair and contribute to healthy, respectful societies. Article 37 of the UNCRC refers to necessary safeguards in outcomes for children in conflict with the law, noting that "no child should be subjected to torture or other cruel, inhuman or degrading treatment or punishment". Article 40 encourages outcomes which nurture children's "respect for the human rights and fundamental freedoms of others" and promote "the child's reintegration and the child assuming a constructive role in society". It also calls for "appropriate and desirable measures for dealing with such children without resorting to judicial proceedings", thereby seeking alternative approaches to the criminal justice system. Principle 11 of the Beijing Rules also refers to the need to find alternatives to the criminal justice system under the section entitled 'Diversion'. In this section, Principle 11.4 specifically includes "restitution and compensation of victims" as an alternative sanction. "Financial penalties, compensation and restitution" are also considered among the 'Various Disposition Measures' under principle 18. Principles 24 and 25 refer to the mobilisation of community members and groups to assist with rehabilitation and reintegration processes for children in conflict with the law.

At the time the international standards for youth justice were being deliberated, there were few practical examples of restorative justice to illustrate the vision for community-based alternatives beyond straightforward restitution, community work or various rehabilitation programmes. While the standards advocated for children to respect the rights of others and endorsed the notion of restitution, they did not consider the option for restorative justice encounters between children who offend and their victims. However, in attempting to convert restorative justice principles into practice, experimentation in the youth justice arena proved 
to be effective in developing models or approaches that give life to restorative justice theory. What has been found is that youth justice approaches that incorporate restorative justice principles have generally tended to reflect the key youth justice principles from the international children's rights instruments. As a result, applying aspects of restorative justice in youth justice matters is now considered valuable in terms of designing alternatives to criminal proceedings for children and young people. ${ }^{314}$

Walgrave (2003:259) has warned that in developing a range of alternatives for children and youth in the name of restorative justice, "the most significant threat to the status of restorative justice within the judicial framework is the enormous confusion which surrounds the idea of 'alternative sanctions'". This said, many contemporary youth justice advocates maintain that the restorative justice continuum described by Howard Zehr allows for different aspects of restorative justice to form part of the various alternative proceedings and sanctions, and that it is desirable for at least some restorative justice principles to be reflected in youth justice practice, even if not completely.

\section{Restorative justice provisions in New Zealand and South Africa's youth justice systems}

Angus, who had sat on New Zealand's Children's Boards during the 1970s, noted that in his view one of the most important principles in any youth justice process was atonement, which enabled offenders to make up for their wrongdoings. He recalled occasions when he sat on the Children's Boards where the outcome would include the child making amends to the victim, such as by repairing something damaged or providing some sort of assistance to the victim in compensation, which he thought would help to bring about closure. While he recognised that these earlier experiences were not explicitly considered in the design of the new legislation, he found these outcomes satisfying. He explained:

When I did my social work training I remember writing something up on reciprocity and atonement as a basis for dealing with young offenders, because it seemed to me to build off how families deal with breaking rules of the family - if a kid in a family hits the younger brother, then they apologise and try to comfort them in some way, then they might suffer some sort of penalty like having to go to bed early - and that's sort of atoning for what they've done and making it good again to restore the fabric of the family in

\footnotetext{
${ }^{314}$ As desired in Article 40 of the UNCRC
} 
a way. It seemed to me a good approach to build on the atonement idea to respond to young people offending. ${ }^{315}$

Restorative justice concepts such as atonement through restitution and making amends for wrongdoing had been occurring to some extent through the former Children's Boards. However, Morris and Young (1987) in their research into Children's Boards found that this mechanism had not met the intention of either diverting children or including families to the extent anticipated in the design, including opportunities for restoration or atonement.

When New Zealand was transforming its youth justice policy during the late 1980s, the key ideas that led to restorative justice theory were just emerging internationally. New Zealand officials were putting together the pieces of information they were receiving from public consultations. Primarily these responded to the needs expressed by the local communities, and particularly related to making amends for past wrongs. Officials were concerned with how they would create a youth justice system that would empower families and communities to make decisions and care for their children and young people in their settings, rather than having them removed by the state. Doolan, who was largely tasked with the development of youth justice policy for the CYPF Act noted: "We had never heard of restorative justice in those days". 316 The members of the youth justice working group believed something was needed to convince the public that the new FGC approach would also provide assurance that young people were being held to account for their offending. Doolan explained how the idea of including victims in the process came about in the design as a means of increasing the credibility of the new approach being proposed:

Victims were included for a very strange reason - well, not strange at the time, but when we think about it in the context of restorative justice, it's not a 'kosher' reason... What we were proposing was to keep children in the context of their families rather than in the context of a group of children who were appearing before the court, and so essentially what would happen would be private. We speculated that there would be a lot of misapprehension about this in the community. How would the community know that this was an honest deal, if you like? That's when we hit upon the idea of including victims, because if victims were part of family group

\footnotetext{
${ }^{315}$ Interview with John Angus dated 8 December 2010.

${ }^{316}$ Interview with Mike Doolan dated 7 April 2010.
} 
conferences, victims could speak for themselves - whether this process was just, whether this process worked for them, whether it was an honest process or whether it was a 'slap over the wrist with a wet bus ticket-type of process' - as a lot of people, and a lot of police would say it was, without evidence to the contrary. So what we were looking to I suppose, was that if we could persuade our victims to come to the conference they would be our honest brokers of whether or not this was a fair, just process. ${ }^{317}$

Maxwell and Morris identified how FGCs reflected what were later to be seen as restorative justice principles during their first in depth evaluation of New Zealand's new youth justice originally published in 1993: Families, Victims and Culture: Youth Justice in New Zealand. Maxwell recalls how when she and Morris joined forces to research the early implementation of the youth justice provisions in the CYPF Act it was a time of exploration and discovery. She noted that she and Morris spent a lot of time deliberating on what type of approach the FGC process reflected:

It was a very formative period...There were growing points and each time we made another leap intellectually... We thought initially that it was a form of mediation. And as we moved on we thought, 'no it is not mediation'. We thought about restorative justice. I didn't meet Howard Zehr until 1992, but I had read his book and I had seen it as the idea of the whole community coming together...It didn't seem to be quite what we were seeing either. So at that point I think we said, 'well, it's not quite any of this'. But as the shape of restorative justice - the notion of it started growing at the same time, we became part of that debate. It was not really until Lode ${ }^{318}$ came and started the international restorative justice association from Belgium that we realised we were talking about restorative justice. So somewhere in that period, our views shifted to recognise rejection of notions of mediation as a model and even community meetings, but to a broader, theoretically based concept of restorative justice.

\footnotetext{
${ }^{317}$ Interview with Mike Doolan 7 April 2010.

${ }^{318}$ Referring to Lode Walgrave, a founding member of the International Network for Research on Restorative Justice who prompted thinking and discussion around the framing of restorative justice at a conference in Belgium in the early 1990's which Maxwell and Morris attended.
} 
Doolan, who was one of the key engineers of the youth justice FGC, had concerns that framing the FGC as a model for restorative justice risked limiting the full purpose and potential of the conference. He noted:

I think it was unfortunate during the 1990s before we got good family group conferences going that restorative justice came in over the top, and became quite narrow. It became focused on offender-victim mediation, what are we going to do for the victim. A lot of family group conferences were about that, reparation, putting things right, working for the victim. Practitioners stopped emphasising the second part, which was 'How do we stop this happening again?', 'How do we prevent further offending and the creation of new victims?' And that requires a services response to the situation that young people find themselves in, in the community and in the family. ${ }^{319}$

In Maxwell's view though, framing the FGC as an example of restorative justice was intended to lift it from the limitations of straightforward victim-offender mediations. While the original publication of Families, Victims and Culture: Youth Justice in New Zealand did not explicitly refer to New Zealand's youth justice system as a model for restorative justice in practice, in the preface to the 2010 edition published as part of the 'Restorative Justice Classics Series', two decades after the implementation of the CYPF Act, Maxwell and Morris reflect that when they were conducting their research they had "come to see the "Family Group Conference' as the first practical example of restorative justice in the modern western justice system. It emphasises the participation of all who are affected by the offending by acknowledging the wrong that was done and by attempting to repair the harm and it seeks ways of reintegrating the young offender into society" (2010: preface). Therefore, in their view, offender reintegration was in itself considered an important feature when framing the FGC as a restorative justice process.

Mike Batley recalled that following the sharing experiences between South Africa and New Zealand in the mid-1990s, the IMC asked him and a colleague at NICRO to set up the FGC pilot in South Africa. In describing what the concept of restorative justice meant to Batley, he noted:

${ }^{319}$ Interview with Mike Doolan dated 7 April 2010. 
It is a mind-set, an approach, a whole philosophy first and foremost...in a sense it was much more than just victim-offender conferencing where some people were limiting it. So for us it was very evident that the concept of restorative justice had so much to offer the criminal justice system of the country as a whole in terms of how we think and understand and respond to the issue of crime. ${ }^{320}$

While South Africa was influenced by New Zealand's youth justice model, policy makers were clear that they had to follow their own journey in conceptualising youth justice processes most relevant to South Africa's unique circumstances. At the time South Africa was developing its youth justice legislation, restorative justice theory was becoming well recognised, and it was a theory that sat comfortably with the values shaping South Africa as a new nation. Zehr had also made a visit to South Africa in the early years of the framing of new youth justice legislation in South Africa, which also helped to influence the thinking at the time. The commitment to restorative justice principles was made explicit in the CJA which states one of its Aims is to: "Expand and entrench the principles of restorative justice in the criminal justice system for children who are in conflict with the law, while ensuring their responsibility and accountability for crimes committed".

As explained in Chapter 6, making the FGC central to South Africa's youth justice system as it had been in New Zealand was not considered feasible by the policy makers. Skelton explained:

We realised that restorative justice for us would have to be a sort of interlinked tract where you have your main stream criminal justice system with your restorative justice options running alongside, and you try as much as possible to refer cases out at all stages of the system. ${ }^{321}$

She further recalled the process around integrating restorative justice principles and practice into the legislation, particularly following De Lange's call for a bifurcated approach:

Things had gone quite badly at Parliament so I had a rather bleak outlook to some extent. But I somehow felt that the restorative justice bits of the Act had somehow survived quite well. Very few changes were made to the FGC

\footnotetext{
${ }^{320}$ Interview with Mike Batley dated 30 October 2010.

${ }^{321}$ Interview with Dr Ann Skelton dated 28 September 2009.
} 
chapter. So there was still openness to using this as a diversion or at the sentencing stage. So to a certain extent, those provisions got through fairly intact, and I would stand by that. But the problem was that the Bill had become 'schizophrenic'. We had the restorative justice, but there was such a tough on crime agenda in the rest of it, that it really didn't fit very well at all. I would now have to say that with the revisions that were made when the Bill went back to Parliament that there's a better fit than there was at that time. So the overall principles are better integrated throughout. ${ }^{322}$

\section{The influence of indigenous practices - 'Utu' and 'Ubuntu'}

While contemporary restorative justice theory has largely been formulated through academic discourse, restorative justice principles are often said to resonate with a number of traditional, indigenous justice practices around the world. Making this connection is generally thought to elevate the worth of restorative justice approaches by suggesting that it demonstrates respect for indigenous cultures and traditions which have otherwise been undermined by western justice systems imported as part of colonisation processes. Both New Zealand and South Africa speak of how indigenous principles and models of conflict resolution are reflected in restorative justice practice in their youth justice systems. These traditions are generally founded on the historical indigenous communitarian social structures of both countries where people's survival and wellbeing depended on the bonds between one another.

In New Zealand, Māori concepts underpinning social functioning emphasised mutual responsibility and reciprocity. The concept of whanaungatanga in traditional Māori society refers to social connections which extend beyond the direct lineal kinship of whakapapa (Thomas, 2006:135). Supporting connections beyond direct kinship helped to harness harmonious relationships between members of different whānau, hapū and iwi, which might otherwise have resulted in rivalry and warfare, particularly in relation to matters of authority, status and belonging. The social code guiding these relationships and maintaining social harmony existed as a concept known as $u t u$, which essentially observed respect for each other's mana. (Quince, 2007) According to Quince, (2007): “The key dynamic in tikanga is to maintain equilibrium between all parts of the human and non-human world. This is achieved through the principle of $u t u$, meaning balance or reciprocity. If things were out of balance, then redress for $u t u$ was sought". Muru is considered a form of $u t u$ through a process

${ }^{322}$ Interview with Dr Ann Skelton dated 28 September 2009. 
of compensation where a transgression has occurred aimed at restoring the social balance. ${ }^{323}$ Metge explained that in the traditional Māori process of talking together to resolve conflict, the participation of all parties is crucial. She noted: "The principle of collective, shared responsibility is of paramount importance in korero tahi...korero tahi places the responsibility squarely on the shoulders of all participants, hosts and visitors alike" (2001:21). According to Maxwell and Morris, (1993:7): “Traditionally, for example, Māori were concerned not only with atonement for the offence and restitution to the victim, but also with the individual offender's potential for integration within the whānau, hapū and iwi'. Metge's findings support the notion that traditionally, Māori whānau rely on collective responsibility for resolving conflict over individual responsibility. She blamed colonisation and policies of assimilation for the breakdown in joint responsibility, noting: "In addressing problems of family stress among Māori...Māori emphasise the damage inflicted on Māori individually and collectively by...the alienation of many Māori from their cultural roots”. (Metge, 1995:24)

South Africa was particularly interested in New Zealand's FGC approach, not simply because it provided a helpful way to reflect restorative justice principles in practice, but also because of the context in which the FGC process developed. South Africans were attracted to the fact that New Zealand's model was inspired by indigenous customs. This resonated with South Africa's communitarian heritage which also included a system of social harmony through reciprocity. This concept is known as ubuntu. While it is often said that ubuntu is a difficult concept to translate into English, a basic translation refers to the notion of shared humanity: 'I am a person through other people'. It suggests that each person's survival and wellbeing relies on other people. Gxubane, a lecturer on youth justice at the University of Cape Town who became active in the youth justice movement, grew up in South African townships during the apartheid years. He explained:

'Ubuntu' means you must know your neighbour and you must feel comfortable about asking your neighbour to look after your house or your children. You make sure that if something goes wrong that you are the first person to help. It is that sense of connectedness, in such a way that if you have done something wrong your family will rebuke you, and your family

\footnotetext{
${ }^{323}$ Historically, the process of restitution through muru could include extreme measures referred to as a "collective plundering of the offender and the family's possessions" by Liu (2007:30). Therefore, restoring the balance was not always consistent with restoring the transgressor into the community.
} 
would go and apologise, either on your behalf, or they take you to go and apologise. $^{324}$

According to Skelton and Frank, (2001:104): "Ubuntu embodies ideas about the interconnectedness of people to each other, the importance of the family group over the individual and the value of benevolence towards all others in the community". With Maxwell's visit to South Africa in 1994, Skelton learned New Zealand's youth justice story. She explained:

We realised that there was a clear connection with what New Zealand was doing...around that time they were beginning to make the connections with restorative justice, and we could see linkages with our own traditional justice systems. ${ }^{325}$

A link developed between key role players from New Zealand and South Africa as a result of their interest in indigenous practices for conflict resolution. This connection helped to advance South Africa's thinking around how to incorporate similar ideas in their process of youth justice transformation. It was noted that traditional indigenous customs in South Africa bore resemblance to New Zealand's FGCs and could therefore be revived as part of their youth justice systems. ${ }^{326}$ In describing the opportunities for a restorative model of youth justice in South Africa in their chapter titled: Conferencing in South Africa: Returning to our future, (in Morris and Maxwell, 2001: 103-119), Skelton and Frank refer to traditional justice processes similar to Māori systems of redress through processes of discussion, negotiation and compensation to restore social balance following a transgression. They noted that while these processes were formally stifled by the apartheid government, they often continued at a community level, and reflected a similar approach to New Zealand's FGC model. A researcher for the Justice and Constitutional Development Portfolio Committee for the Child Justice Bill noted: "It (restorative justice) just made complete sense to me...in fact it fits pretty well with more African ideas and a more African approach to justice". 327

\footnotetext{
${ }^{324}$ Interview with Thulane Gxubane dated 13 October 2009.

${ }^{325}$ Interview with Dr Ann Skelton dated 28 September 2009.

${ }^{326}$ Interestingly, it appears that restorative justice models that include aspects of indigenous practice have in part been aimed at reaching out to disadvantaged indigenous social groups representing the highest percentages in crime statistics in Western jurisdictions, such as New Zealand, Australia, Canada and South Africa.

${ }^{327}$ Interview with researcher for Portfolio Committee for Justice and Constitutional Development dated 8 October 2009.
} 
Cunneen (2004) argues that there are risks in simplifying the connections between emerging restorative justice models and indigenous justice practices, describing these connections as "trivialising and patronising" (2004:345). He suggests that merely being inspired by or incorporating aspects of indigenous processes in the creation of restorative justice approaches can undermine the rich cultural context and nuances in which such practices were derived. This tends to becomes more pronounced when countries try to copy pre-packaged models from other settings. Furthermore, Cunneen (2007) questioned the appropriateness of trying to blend indigenous customs into western legal frameworks. He noted that this can be confusing and contradictory for indigenous populations in places where government structures and policies have systematically undermined indigenous cultures. Cunneen stated: “A problem for indigenous people is that the state may be seen to lack legitimacy. A restorative justice programme initiated and controlled by the state may be viewed with suspicion by indigenous peoples, who see the state in terms of its colonial functions" (Cunneen, 2007:117).

While indigenous practices were referred to during the development of both the CYPF Act and the $\mathrm{CJA},{ }^{328}$ in order for these practices to be moulded into generic practical policy solutions, the final products became structured, such as through accreditation requirements, which diluted organic traditional practices. Doolan, who had attended the community consultations during the 1980 s, described the tension in the process:

\section{Māori people made a huge contribution (in terms of) culture and relevancy.} Again, we never really got a prescription. We got a lot of emotion. We got a

\footnotetext{
${ }^{328}$ The Objects of the Child Justice Act of 2008 include the object to "promote the spirit of ubuntu in the child justice system through-

(i) fostering children's sense of dignity and worth,

(ii) reinforcing children's respect for human rights and the fundamental freedoms of others by holding children accountable for their actions and safe-guarding the interests of victims and the community,

(iii) supporting reconciliation by means of a restorative justice response and

(iv) involving parents, families, victims and, where appropriate, other members of the community affected by the crime in procedures in terms of this Act in order to encourage the reintegration of children, (Ashley, just want to check the change here from Roman numerals to letters)

(c) provide for the special treatment of children in a child justice system designed to break the cycle of crime, which will contribute to safer communities, and encourage these children to become law-abiding and productive adults (d) prevent children from being exposed to the adverse effects of the formal criminal justice system by using, where appropriate, processes, procedures, mechanisms, services or options more suitable to the needs of children and in accordance with the Constitution, including the use of diversion and

(e) promote cooperation between government departments, and between government departments and the non-governmental sector and civil society, to ensure an integrated and holistic approach in the implementation of this Act".
} 
lot of anger. We'd have people standing on the marae with Puao-Te-Ata-Tu in one hand and the law in the other and saying: 'Get rid of your law and institute this as law!'

You couldn't. They were fundamentally different instruments. So what we had to do as policy advisors was to have a third ear saying, 'What does this mean? What's the main thing coming through here?' What was coming through very strongly in our third ear was the pain of the loss of children over many generations, the unfairness that people felt about the way the state intervened and interfered in their lives, the anger from the sidelining of their social system and the way that they make decisions, including the role of the whānau, hapu, $\underline{\text { iwi. }}$. All of these things were never aligned and there was a lot of angst about that expressed by Mãori.

So how could we get a system where Māori themselves determine the process of decision-making? We had a clear steer from the government of the day that they were not prepared to develop a dual system of justice. There was to be one system of justice, and our job was to make that system as flexible as it possibly could be to incorporate any culture's understanding about how decisions are made, how problems are solved and how plans for improvement are formulated. Māori have a very strong tradition of communal decision-making. At the end of the day, that's what we borrowed. Mäori contribution to the whole outcome was that they opened the ears of government to be willing to institute a change. That was quite radical in the day. ${ }^{329}$

Hall, who was involved in the consultations and the development of the Puao-Te-Ata-Tu report, reflected on what she and her colleagues understood the community wanted and how this was converted by government officials into policy and practice. She considered the metamorphosis to be the result of non-Māori being responsible for the actual construction of the policy, legislation and operational guidelines:

That's what happens when a very, very well intentioned Päkeha Secretary General of Social Welfare structures our plan. It comes out the way he sees

${ }^{329}$ Interview with Mike Doolan dated 7 April 2010. 
it and not the way the Mãori see it. Structures that he knew from his perspective - wouldn't have been anything that any of us Māori would put up, but then we couldn't get it through. The implementation was all done by government, social welfare. They designed the process. There wasn't much input from us. 330

Therefore, irrespective of whether the community had a voice in how traditional practices could enhance policy and processes for youth justice, when the statements from first-hand experiences were taken back to the drawing board by government officials, they resulted in processes that were still unfamiliar to local communities. This ultimately undermined opportunities for genuine community empowerment and the expansion of tikanga Māori in these processes. Judge Becroft reflected on his experience of FGCs as the Principal Youth Court Judge in relation to its benefits for Māori in particular. He noted:

I think at its best it offers a context and an opportunity, and I guess a stimulus for Māori families to be much more involved in decision-making about their own young people, and for the Mãori community to be much more involved. But that will mean conferences that are well prepared, well organised, that may be held on a marae, that bring in a cultural dimension - maybe through a senior 'kaumatua'331 being invited in. It may be something we haven't delivered on. I think the opportunity is still there. ${ }^{332}$

Given that the FGC design was intended to be flexible and able to respond to a wide range of cultures including Māori, and that Māori had contributed significantly to the policy making processes through extensive consultation, it would have been helpful to incorporate some specific processes of accountability to support more indigenous Māori approaches to FGCs. Maxwell agrees FGCs have greater potential to empower communities and families:

This is the missing element - the community support, the community programmes, the mentoring that is needed if we are going to change these kids' lives, and support the families who obviously need a lot of help in many cases. So yes, the family group conference has been an incompletely

\footnotetext{
${ }^{330}$ Interview with Donna Hall dated 20 March 2010.

${ }^{331}$ Māori term for community leader.

${ }^{332}$ Interview with Judge Becroft dated 9 November 2009.
} 
realised dream, but it has been realised in many important ways. I guess that's where I feel I am now, and I feel we were even then. ${ }^{333}$

South Africa has also experienced the disintegration of traditional practices for conflict resolution and reconciliation that reflected the concept of ubuntu. Gxubane expressed some cynicism when reflecting on his perception of the community's understanding of restorative justice as proposed in South Africa's child justice legislation and its relationship to the community's contemporary experience of ubuntu.

I think the Act is trying very hard to entrench the principle of $\underline{u b u n t u}$.

Ubuntu is lost. I think it's because of crime. People are protecting their own - it's every man for himself. We are talking now about the black middle class who are adopting the western standards of living. They don't think, 'I have connected with my neighbour'. In fact they feel disconnected, because they don't trust. You find that people are staying next to each other, but they don't trust each other, and that's not ubuntu. I think that it's gone, especially amongst African people themselves, those who are deprived, those who have nothing, they'll still take from those who have little. So it is going to be a challenge. Once we use it, maybe we will start to see some fruits and people will say, yes in fact this approach does pay off. ${ }^{334}$

Batley echoed Gxubane's concerns about the erosion of ubuntu in South African communities and admitted this can affect their acceptance of restorative justice approaches when wary of the impact of crime on their daily life. Skelton and Frank acknowledged this challenge to the upholding of ubuntu in the design of the youth justice system in South Africa which aimed to include restorative processes such as FGCs. However, in identify ing the constraints, they also noted that "the process of conferencing itself may provide a catalyst to rebuild families and communities and may provide a springboard for a recommitment to ubuntu”. (Skelton and Frank, 2001: 117)

There remain useful similarities between what restorative justice wants to achieve and certain indigenous models of justice. Unpacking this further might mitigate the potential for neocolonialism which exists in some state imposed models (Bazemore et al., 1997), and reduce the risks of power imbalances in individual restorative justice encounters, whereby social

\footnotetext{
${ }^{333}$ Interview with Dr Gabrielle Maxwell dated 29 March 2010.

${ }^{334}$ Interview with Thulane Gxubane dated 13 October 2009.
} 
class or status contributes to these possible power imbalances. On the other hand, while increasing the scope for more genuine cultural responsiveness, it would still be necessary to ensure that one cultural approach does not dominate another to the point of unfairly tipping the balance in multi-cultural conferences. Cultural nuances and sensitivities are of particular relevance in restorative justice-type settings and processes for both New Zealand and South Africa, particularly given their histories of race relations and dynamic, diverse contemporary societies. Therefore, conference coordinators need to fine tune the process to enable to most satisfying and fair outcomes for all participants. This means that victims feel heard and that the response will help to make amends for the offending and that the outcome is proportionate to the offending and does not set the offender up to fail. This in itself requires input from all the participants, including when setting out the expectations at the start of the process. As noted, it is about showing all parties respect and finding ways to empower the participants by supporting their self-determination as the process unfolds. While this is considered a key principle in the process, the creation of state imposed restorative justice models that include rigid terms and conditions suggests that there has been a fundamental reluctance for states to relinquish their control over criminal justice matters. Being able to recognise this however, means that there is still a chance for both New Zealand and South Africa to consider how to best incorporate relevant indigenous practices and customs in to restorative justice processes. Particularly if these factors help to advance the restorative justice outcomes and if this is wanted, appreciated and accepted by all the participants of the restorative justice process. ${ }^{335}$ Reflecting on New Zealand's promise of being more responsive to Māori in their justice system, Hakiaka stated that "the state needs to acknowledge the validity of Māori processes as cultural imperatives and gives them the control over their decision-making processes" (Hakiaka, 2004:361).

\section{Conclusion}

This chapter demonstrates that policy makers in both South Africa and New Zealand wanted to design youth justice systems that would include strategies to repair harm and prevent further offending. Both countries were also interested in creating approaches that could resonate with local indigenous practices, and be meaningful for communities whose traditional practices had been sidelined through historical social engineering. This was by

\footnotetext{
${ }^{335}$ Gallinetti, Redpath and Sloth-Nielsen referred to the potential tensions in restorative justice dynamics in the South African context in their article Race, Class and Restorative Justice in South Africa: Achilles heel, glass ceiling or crowning glory published in the South African Journal of Criminal Justice (2004).
} 
seeking ways to bring the key stakeholders together to find solutions that would address the offending and support children and young people's pro-social reintegration. Restorative justice theory seemed to capture these core principles. The theory guided practitioners working through the complex dimensions of crime committed by children and young people, irrespective of whether restorative justice theory was specifically considered when designing the new approaches. A key advantage of the restorative justice approach for both countries was that it allowed for a range of outcomes when responding to the unique needs of the participants. However, for this to be done well, participants need to be prepared in advance, and facilitators must remain sensitive and responsive to the needs of all participants, empowering them to shape the outcomes that reflect the restorative justice principles while delicately balancing any potential power dynamics. This approach can be particularly beneficial in dynamic, multi-cultural settings like New Zealand and South Africa. However, if practitioners take short-cuts rush through the process or simply go through the motions to tick the boxes, the power of restorative justice process can wither and the approach risks losing credibility over time. 


\title{
Chapter 9
}

\section{How social entrepreneurship contributed to youth justice transformation in New Zealand and South Africa}

\author{
Our best hope for humanity lies in the power of socially motivated, highly \\ empowered individuals to fight for changes in the way we live, think and \\ behave.
}

(Skoll, 2006: v)

The experiences of shaping both countries' youth justice systems demonstrate how the combined power of committed individuals who unite around a common cause can generate social change. Although the term 'social entrepreneurship' is relatively new, the concept itself has probably been apparent over centuries and in various contexts. The term was made popular by William Drayton when he started an organisation called 'Ashoka: Innovators for the Public' in 1980. The driving principle behind Ashoka was to harness business entrepreneurship strategies to address fundamental social problems and to drive change (Davis, 2002:6). Although there are some fundamental similarities between social and conventional entrepreneurs in that they are both innovative and visionary, Ashoka did not view financial reward as a necessary by-product of the social mission. In fact, in seeking a working definition for the concept of social entrepreneurship, Roberts and Woods (2005:46) state that "many social entrepreneurs would baulk at seeing their services as 'marketable' because their raison d'être is to address a social need, not a commercial one". David Bornstein (2007), a prominent promoter of social entrepreneurship initiatives, explained that, unlike the business entrepreneur, the social entrepreneur is not motivated by monetary wealth but rather by changing the social status quo to improve people's lives and circumstances. He stated, "If you are phenomenally successful, you don't get rich - you change the world". Ashoka's emphasis is on outcomes which reflect systemic changes to a social problem. Success is ultimately reflected in the changed order (Leviner et al, 2007).

The principal quality of the social entrepreneur is their genuine, unwavering commitment to a social cause which requires innovation, dedication and savvy to address, and their wealth is created by the positive changes to respond to the identified social need. Drayton (in Davis, 2002: 6-7) states: “The entrepreneur exists to make his or her vision society's new pattern. 
(S)he is married to that vision, in sickness or in health, until it has swept the field". Nevertheless, he cautions that merely being a visionary and committed to a cause is not sufficient to be a successful entrepreneur. There must be an element of planning and strategising around how to translate the vision into social change, coupled with perseverance until the vision has been instated. The solution to the social problem must be creative and moulded to suit particular needs. This chapter describes how key role players responsible for youth justice transformation in New Zealand and South Africa possessed social entrepreneurial qualities that helped them to drive the changes despite significant barriers.

\section{Characteristics of the social entrepreneur}

A term that has been given to individuals tasked with scoping policy options is the "policy entrepreneur'. According to Mintrom (1997:740) “Policy entrepreneurs are able to spot problems, they are prepared to take risks to promote innovative approaches to problem solving and they have the ability to organise others to help turn policy ideas into government policies". Cho (2006:35) stated: "Entrepreneurs have a vision for social change and mobilise resources to pursue this vision: they are ambitious, independent and focused on achieving ends ". Although there appear to be similarities between social entrepreneurs and policy entrepreneurs, the parallels are not apparent in the related literature. This may be due to the differences in the underlying motivations driving the different entrepreneurial ventures. Roberts and Woods (2005) explain how the definition of social entrepreneurship is largely based on the particular characteristics of social entrepreneurs. Drayton states that the work of the social entrepreneur is "not a job...it is a life calling" (Drayton in Nicholls 2006:55). Accordingly, the term 'passionate' is often used to describe social entrepreneurs (Handy in Roberts and Woods 2005:46). Social entrepreneurs are also described as "caring, compassionate and moral" (Roberts and Woods, 2005:47). Mair and Noboa (2006:124) note that social entrepreneurs are motivated by a strong sense of empathy for those people for whom they want to see social change. Driven by a vision and mission to transform systemic structures and social status quo, Dees (in Nicholls 2006:23) believes that social entrepreneurs are "bold" and "relentless" in their pursuit. Considering the practical and academic criteria identified to define the social entrepreneur, Roberts and Woods (2005: 49) proposed the following definition: 
Social entrepreneurship is the construction, evaluation and pursuit of opportunities for transformative social change carried out by visionary, passionately dedicated individuals.

While both policy entrepreneurs and social entrepreneurs identify needs and seek out, develop or introduce innovative policies to address problems, policy entrepreneurs are not necessarily driven by the same kind of personal passion for a cause or an unrelenting determination to alter the status quo that characterises social entrepreneurs. Compared to social entrepreneurs, policy entrepreneurs may more readily change direction around a policy approach if they do not believe it will take root. In contrast, social entrepreneurs are more likely to fight tooth and nail for a particular vision. It is the difference between doing something because it is a job versus because it is a life calling. Therefore, it is argued that while many policy entrepreneurs may be social entrepreneurs in that they are driven by a life calling, passion and dedication to a cause, they do not necessarily have to demonstrate these qualities to merely be considered policy entrepreneurs.

The in-depth interviews conducted with the selected research participants for this thesis revealed that they each possessed a set of characteristics consistent with the definition of social entrepreneurs. They were all empowered individuals motivated by their exposure to negative social circumstances, who empathised with the people most affected by the situation that drove them to effect change. They reflected qualities of both passion and compassion and followed their mission as though it was a life calling. The participants demonstrated that they were compelled to identify the needs in relation to youth justice, the effects of the existing systems on children's development and wellbeing and its limitations in relation to promoting long term public safety. Their own significant life experiences prompted their interest in creating an alternative vision for youth justice based on a core set of values and principles that called for community-focused, rights-based, restorative justice approaches. Prabhu (1999:124) recognised that social entrepreneurial ventures often start with exposure to a situation that causes concern or distress: "the context of social entrepreneurs, that is, their involvement with the social sector or their exposure to social issues, not only allows them to recognise social opportunities, but also seems to turn them into altruistic citizens". The selection of comments below from some the participants reflect how their personal experiences motivated them to become agents of change: 
I was very involved at the practice end. Every Monday I used to trail down to court to hear the sad stories of the young people who had been arrested and therefore had to appear in court...as I look back, I had some questions about the justice of how some kid who shoplifted persistently could end up in detention essentially for 12 months or 18 months because their offending came out of a welfare paradigm. So I was quite a supporter of a new approach that would in fact be fairer to young offenders because it would deal with their offending out of more of a justice sort of paradigm.

John Angus

I had a personal investment, as I was still shocked and horrified at how kids in institutions were being treated...I was just interested to make sure that kids weren't bashed around by police.

Robert Ludbrook

We set up a pilot in Porirua, two or three of us who were really interested in doing something really different...I think all of us who played small parts in it somehow helped.

Judge Carruthers

They put the new prosecutors in what was then referred to as the juvenile court. I saw what was happening to them and how there wasn't a special system for them. It was a really tough regime. So I realised this was something that really needed to change.

Ann Skelton

You know, you get that one child who really defines the way you approach things in the future. Often in the heat of a Parliamentary debate where the Chairperson of the Portfolio Committee was talking I would say: 'Have you been in court? Has a child sat and sobbed on your shoulder because he has been hurt in Pollsmoor? No?' So those are particularly important. You don't recognise the importance when you're in it, but obviously it just leads to whatever you are doing.

Jacqui Gallinetti

We had a huge problem with children coming from the street. We felt that they were being discriminated against because they didn't have a mother or father to sign for them. We would negotiate with shelters to see whether they would be prepared to act as guardians for these 
children so that they could enjoy the same rights and privileges as any other children. This was a huge issue for me.

Thulane Gxubane

Having worked with prisoners with NICRO and prior to that as a probation officer and a parole officer for the John Howard Society in Montreal, Canada, I realised how destructive imprisonment is. My dream was to work on a system that was more positive. Restorative justice in my mind was the answer to that. That is why I was so excited about using restorative justice as the philosophical framework to develop the new youth justice system.

Roland Graser

A common feature in these statements is each participant's concern for children's wellbeing in the face of adversity based on their own personal exposure to the negative circumstances. This was mostly due to the effects of state-run systems and institutions, which resulted in the belief that there needed to be a fundamental change to the status quo. Underlying their concern was children's vulnerability and the need for systems to be sensitive to the particular needs of children in difficult circumstances and to protect them from harm and discrimination. This was the key social need underpinning the drive for youth justice transformation in both New Zealand and South Africa led by individuals who were distressed by what they had witnessed, heard and experienced.

\section{Joining forces to effect change}

According to Bornstein (2002:8):

The process begins with an entrepreneurial author: an obsessive individual who sees a problem and envisions a new solution, who takes the initiative to act on that vision, who builds teams to market that vision, who provides the creativity, energy and sustained focus to overcome the resistance, and who, decade after decade, keeps promoting that vision until a once-marginal idea becomes a new pattern.

While the power of individual social entrepreneurs is often significant, the strength behind creating a transformative movement often lies in their ability to connect with like-minded individuals who share their vision, passion and tenacity to drive change. Stone (2000) highlighted the importance of networking between key role-players to promote a particular 
policy agenda. She noted that role players "can include journalists, researchers and policy analysts as well as elected officials and bureaucratic leaders". The choice of individuals tasked with advancing a policy process will often influence the direction the policy will take. This is often as a result of interests, networks and alliances the policy entrepreneurs will make in order to formulate an argument and advance their proposition (Mintrom, 1997:739). Stone (2000) reflected on the strength of networking and linking in with coalitions who share similar ideas and values in shaping policy around certain areas. She notes, "Individual experts and knowledge organisations are not simply policy entrepreneurs but also a central force promoting collective policy learning" (Stone, 2000:7). She believed that it is through a process of agreement and shared understanding of an issue between members of a network that policies are moulded. Sabatier (in Stone, 2000) refers to these networks as "advocacy coalitions"; with members of the coalition jointly form the terms and conditions around a policy direction. Mulgan (2006:91) explains, "social entrepreneurship is more the chemistry between people rather than stemming from a single source". Social entrepreneurs are not limited by one strategy or way of doing things, but operate through different networks and systems in order to achieve their objectives. The added advantage is that this way of working broadens the scope for developing innovative solutions (Perrini and Vurro, 2006:75). Therefore, it is through joining forces and creating networks of change agents that muscle can be added to the mission and the vision can spread. This increases the opportunities for widespread support, both from the public and from the government.

Using both the New Zealand and South African experiences as examples, the joining of forces between motivated individuals became instrumental in advancing the process of youth justice transformation in both countries. First, concerned individuals who had started to become vocal and active in their capacity started to gravitate towards each other, often through joint forums and conferences that were emerging at the time. This gave them more opportunities to share their experiences, expand on their vision and spread their influence. ${ }^{336}$ From a social entrepreneurial perspective, the process of uniting starts to fan the flames of change, and allows movements to gain momentum. In describing the process in New Zealand, Doolan noted:

\footnotetext{
${ }^{336}$ In New Zealand, this was strongly evident in the joining and sharing ideas between key role players including Renouf, Angus, Doolan, Maxwell, Judge Brown and Judge Carruthers as described in Chapter 7. In South Africa the key forces that initially united were Shapiro-Liu, Morris, Skelton and Pinnock,and Muntingh who were then joined by Frank, Sloth-Nielsen and Gallinetti as described in Chapter 10.
} 
It is really important to understand that that piece of legislation (the CYPF Act) in its totality developed in a team context. While I was the policy lead for youth justice, Jacky Renouf was the policy lead for the whole of the Act, and my work slotted into hers really. ${ }^{337}$

Renouf reiterated the team effort explaining:

Mike went off knowing that I was going to be running this thing. So we set up a process whereby we kept in touch with what he was finding out in England. He was very good at keeping in touch and sending back ideas and reacting to things and saying: 'We're thinking along these paths - what are your thoughts?' He was the person who really had a lot of detailed knowledge. We had two other people on the working party who really were very good - they were the two 'in situ' on the working party, and keeping in touch with Mike. ${ }^{338}$

In New Zealand, an advantage was that the key policy advisors were committed to developing a system that addressed the problems faced by children in the welfare system by empowering families and communities to reclaim responsibility for their children. They were able to garner support for this position and approach by uniting with other influential people who shared their views. This approach collected ideas and experiences from around the country, helping to build up their stance in the youth justice debate that had emerged at the time. Renouf recalls:

The Youth Court judge, Carruthers, was very keen. I remember having a lunch time meeting with him and we sort of 'chewed the fat'. This was the interesting thing about the working party because it was sort of bouncing things off a range of people. In fact Gabrielle (Maxwell) was one of those people. We got people like her and tested ideas against them, and they would come back with some additional interesting points. They were incredibly important, because their expertise was helping to downplay other expertise that had been around before. We actually needed as a Department to have a wider set of sponsors in the community to get those ideas, to get Michael Cullen and the Government feeling okay: 'We have a number of

\footnotetext{
${ }^{337}$ Interview with Mike Doolan dated 7 April 2010.

${ }^{338}$ Interview with Jacky Renouf dated 30 March 2010.
} 
other credible people who are saying the same as the Department is saying'. So that is what was happening during that process.

By that stage other groups had mobilised in the community against this highly professionally autonomous group that were going to be the 'judges and jury' in child abuse cases, and so you had Māori and Pacific people on one hand, but you had a number of the voluntary organisations - you had Departmental social workers as well who were totally at odds with this piece of legislation (The Children and Young Persons Bill of 1984). Once again, this Bill was sort of ready to drop into Parliament and be passed, and there was another election. ${ }^{339}$

It is arguable that if committed, well-positioned individuals in New Zealand not been sensitive to the voices of Māori and push for an alternative social welfare model around family empowerment and responsibility, the FGC is unlikely to have been conceptualised. The possibility of this alternative history for New Zealand illustrates the potency of the collective forces of personal experience, consultation, innovation, passion and persuasion needed to successfully drive change. Judge Carruthers captured the process of the joining of strengths and interests, political will and the promotion of new ideas in New Zealand from his perspective:

Mick Brown, who became the first Principal Youth Court Judge, had become a friend of mine, and he'd been doing this different way of working in Waitakere. He'd gotten a 'toe in' with the Hoani Waititi Marae, he got a really good Māori liaison officer, and he was starting to divert kids to the marae, and gave me a bit of a lecture on it all...and then there was this other thing that Mike Doolan had come up with - it was a family empowerment model for both youth justice and care and protection cases...the Director General of Social Welfare put together a meeting and sought out what professional differences there were about all this, and we had a very rigorous discussion. At the same time the powers came on like the officials and people like ourselves. There was a change of mood in government. Cullen came into power so there was a whole parliamentary change as well and we ended up with the '89 Act.

${ }^{339}$ Interview with Jacky Renouf dated 30 March 2010. 
In the middle of that I met Gay (Gabrielle) Maxwell for the first time. She came and sat in the back of the court. She was able to put context around it and that's when she got involved. It was just fortuitous really because she turned out to be such a strong advocate for restorative justice, which was never identified as such but became so as a matter of practice and for this different way of working which has been picked up by so many people around the world. ${ }^{340}$

Had these elements described by Judge Carruthers not converged at the same time, New Zealand might also have lost the opportunity to contribute to other international phenomena emerging at the same time - most notably international standards for children's rights and restorative justice principles. Without the development of the youth justice FGC, it is unlikely that New Zealand would have been in a position to promote its youth justice model as a practical example of restorative justice and a community-based alternative to custody for children in conflict with the law - a model which has since influenced you th justice policy makers around the world in the design of their youth justice models, including South Africa.

Like in New Zealand, the role of social entrepreneurship in South Africa which contributed to youth justice changes occurred in stages. Both experiences illustrate the advantage of political timing in which government support helps to advance the ideas of driven and committed individuals. The first phase of the movement effectively started during the state of emergency in the mid-1980s. This was with the collective concerns expressed by the DPSC and the Black Sash in particular, gathering support for the release of children in custody. These activists raised their voices during some of the darkest years of the apartheid era by heading the 'Free the Children' campaign. They were even successful in seeing a number of children released as a result of the pressure they put on the government of the day. What is different about this campaign compared to the youth justice movement that took place around the end of apartheid is that, while this first group of activists made a humanitarian appeal for the release of children in custody, they were not proposing a fundamental change to the systems and processes that were leading to children being imprisoned. This thesis identifies a generation of activists who emerged in the early to mid-1990s when South Africa's political terrain was shifting dramatically following the release of Nelson Mandela and the start of discussions on a Convention for a Democratic South Africa (CODESA). Slowly but surely,

\footnotetext{
${ }^{340}$ Interview with Judge Carruthers dated 17 February 2010.
} 
these activists started experimenting with ideas and processes in their capacity that could offer credible alternatives to the existing youth justice policies and practices. In developing these alternatives, they became aware of concepts for children's rights, restorative justice and diversion, and tapped into indigenous customs which helped to formulate a new system for youth justice in South Africa.

While these individuals seemed to find each other and influence, encourage and support each other's emerging practices and ideas, the spread of their vision might have been limited without the strong backing of the new Minister of Justice, Dullah Omar in the first postapartheid government. As this thesis reveals, many of these social entrepreneurs were already well connected to Minister Omar through the CLC at the University of the Western Cape. He encouraged them to construct youth justice legislation that would reflect the emergent human rights framework for most social policy making taking place in South Africa from the mid1990s. This was an ideal platform for committed youth justice advocates to advance their cause for developing and creating a youth justice system based on children's rights principles within a restorative justice framework. Their approach started to gain in influence when the government realised the lack of existing community-based alternatives to imprisonment after releasing all children remanded in custody in 1995. Reflecting on the strength of social entrepreneurship ventures, South Africa's core network of youth justice activists were able to expand and spread their ideas widely, and to convince the judiciary and frontline practitioners to try their new way of dealing with children in conflict with the law. The setting up of the Child Justice Alliance played a critical role in attracting a range of groups and individuals to the new vision for youth justice in South Africa, including from the government, nongovernment and academic sectors. Gallinetti, who led the Alliance explained:

We had these little workshops, the 'road show', where I took my suitcase and presentation around, and signed people up to this newly formed Alliance. We got a lot of members that way. It was a very loose organisation...it's a voluntary network of people who are concerned with child justice issues. The people that we spoke to helped design the vision. ${ }^{341}$

Gallinetti's description exemplifies Nicholls' (2006:12) view that: "social entrepreneurs engage with network activity not only to leverage resources and strengthen their own venture, but also to deliver impact and to create new social value". Nicholls goes on to note: "Central

${ }^{341}$ Interview with Dr Jacqui Gallinetti dated 15 October 2009. 
to this strategic approach is a stakeholder world view that prioritises maximising positive impacts across the web of external and internal actors connected to a social venture". Muntingh's reflections on the South African experience strike a similar chord:

What is evident is the work of individuals and organisations grew tremendously in a very short period of time, and the Department of Social Development's approach was to consult civil society. I think as a result of that, people shared more information and got an agreement on what needs to be done. Those networks were very valuable. ${ }^{342}$

The youth justice advocates in South Africa were making significant inroads into changing the approach to the youth justice system, with grassroots transformation occurring in spite of the lack of formal policy or legislation. However, the Portfolio Committee's ability to stifle the process under De Lange's influence illustrates the power of political forces when trying to turn a vision into reality. At the same time, the refusal of the united and like-minded child justice advocates to compromise on their vision, demonstrated their commitment to changing the status quo in the particular direction they were proposing. Instead of buckling under the demands to alter fundamental aspects of their draft legislation, they continued to advocate for its core values and principles, promote them in practice and seek evidence to prove their feasibility until they could put their proposals back on the political agenda. While this was not for another six years, the interim phase proved worthwhile in shaping a stronger position in time for the change of leadership in the Justice and Constitutional Development Portfolio Committee to support the values and instate the new vision for youth justice as law in South Africa.

Skelton recollected:

The Child Justice Alliance managed to stay alive during all this time, and I think one of the real interesting success stories on this whole journey was the whole NGO involvement and how solid it was. Most of us still managed to re-emerge from wherever we were and whatever we were doing. ${ }^{343}$

Frank described how when the opportunity to revisit the Child Justice Bill came about suddenly, the network came together quickly and efficiently to prepare for the presentations:

\footnotetext{
${ }^{342}$ Interview with Lukas Muntingh dated 1 October 2009.

${ }^{343}$ Interview with Dr Ann Skelton dated 28 September 2009.
} 
It was almost like we'd all been waiting for this, we were ready for it...I remember everyone cancelled their holidays...The Parliamentary hearings were in March (2008). Everybody was desperate for it to happen and then we had one month to do it...But when the Alliance came together, we worked incredibly well. We divided things up, we managed to get an advanced version of the Bill, and we knew what the changes were going to be...everybody made submissions in Parliament on their specialised areas, so it worked out well in the end. We had agreed to the principles at the very beginning. The Alliance as a whole had understood what we wanted to achieve. $^{344}$

Despite the re-uniting of forces, Sloth-Nielsen admitted to how tiring this process became: "It becomes harder to muster up the same passion and fire through yet another round of politicians, all of whom are wet behind the ears - but one does". ${ }^{345}$ Gallinetti noted, "It all goes in cycles and you've got to carry on dealing with it. You can't moan - you've just got to deal with whatever happens". 346

\section{State support for social entrepreneurial ventures}

Mulgan (2006:81) identifies the importance of the state in advancing social entrepreneurship: "the view that the government is the enemy of social entrepreneurship is at odds with the historical evidence and at odds with contemporary experience...the best states for social entrepreneurship are those that engage with civil society, that are open, accessible active and supportive". While the social entrepreneurial venture and the joining of forces can assist to advance a cause, without government support it becomes very difficult to embed the new approach in order to make genuine inroads to changing the status quo. According to Kligner (2006:55), "Replicating a successful practice in public administration requires government capacity to overcome barriers to innovation diffusion and adoption. Among other things, capacity implies a favourable policy environment, leadership support, stakeholder involvement, adequate funding and an appropriate transfer plan". While state representatives generally need to be persuaded of the benefits of the proposed approach, if they support the idea and agree with the need for change, the opportunities for change increase significantly.

\footnotetext{
${ }^{344}$ Interview with Cheryl Frank dated 28 September 2009.

${ }^{345}$ Interview with Dr Julia Sloth-Nielsen dated 16 October 2009.

${ }^{346}$ Interview with Dr Gallinetti dated 15 October 2009.
} 
Using the experiences of youth justice transformation in New Zealand and South Africa as examples of social entrepreneurship, it is evident that the acceptance and support of key government representatives in both countries of the social entrepreneurs' vision is testimony to the need for state engagement and support to effect social change. In New Zealand, had a new government not come into power with Minister Cullen at the helm of Social Welfare in the late 1980s, the opportunity to revise the existing draft Children and Young Persons Bill of 1984 to better incorporate the voices of the community in the design of the new youth justice approach might have been missed. This could have resulted in the scales tipping towards the highly professional approach to responding to children and young people who offend, with minimal family involvement in decision-making. It is also possible that the social welfare approach to addressing children in conflict with the law might have remained, without the introduction of the justice model by Doolan. Renouf et al referred to the significance of the policy review process resulting in the Children, Young Persons and their Families Act of 1989. They noted that "the Act itself and the process of its evolution provide a rich vein for mining by political scientists/sociologists" (Renouf et al 1989:10). Among the issues highlighted, Renouf et al (1989:11) noted:
The process illustrates the accessibility of ministers in New Zealand to interest groups and the power which key figures in interest groups can obtain...It was only at the third policy phase that officials had some considerable command of the policy agenda, rather than reacting to the interest group agendas and ministerial dictates. Up until that time (and indeed during 1987 and 1988), public servants played a variety of roles: spokespeople for the disadvantaged and less articulate, mobilisers of less organised interest groups, spokespeople for practitioners mediators and consensus seekers. Such roles are at some variance with perceptions of social policy advisors as providers of rational, research-based advice to ministers as the basis for social policy changes.

South Africa experienced a similar phenomenon in the process of changing youth justice policy. Policy makers united from various interest groups with particular agendas which they hoped to advance through the policy and law making processes. Despite facing significant barriers following the initial Parliamentary process, their commitment and perseverance prevented the progress of De Lange's tinkered version of the legislation, which included the bifurcated approach that they fundamentally disapproved of. In the end, South Africa's youth 
justice social entrepreneurs demonstrated that they wielded considerable power over the process, which they sustained until they found appropriate support from the government for their mission. The new Chairperson of the Portfolio Committee for Justice and Constitutional Development, Yunus Carrim, played a crucial role in advancing a version of the legislation that satisfied the interest groups. As Skelton noted, "We had a very good relationship with that later Portfolio Committee to the extent that they allowed us to play a participatory role all the way through". ${ }^{347}$ Carrim's willingness to consult with the social entrepreneurs as well as include them in the internal Portfolio Committee process shows how they were able to make changes from the inside and that the rationale for their proposals were agreed with and taken seriously by the Committee. As noted in Chapter 5 though, Carrim pointed out that while the Portfolio Committee regularly consulted with the persuasive and dedicated group of child justice advocates, the Committee was likely to independently arrive at a similar approach under his leadership due to its own support for a similar set of values and principles for dealing with children in conflict with the law. This serves as a reminder that the Committee maintained overall control over the direction of the process. Nevertheless, the importance of the ongoing partnership between government and the civil society was recognised as being critical to the successful implementation of the CJA by Ms Sindane, the Director-General for the Department of Justice and Constitutional Development in her Department's Annual Report on the Act (2011:8). She noted:

\section{I further wish to thank the members of the Child Justice Alliance, National Operational Inter-sectoral Committee, the Provincial Child Justice Fora, the Non-Governmental Organisations and the Civil Society for their devoted efforts in making the first annual implementation of this Act the tremendous success it turned out to be. Indeed, it is through joined hands that we can create a safe country for our children.}

\section{Generational handover}

In order to ensure the survival of a social entrepreneurial mission and to entrench the changed status quo over time, a new generation of social entrepreneurs is needed to nurture and sustain the vision. Because the cause is founded on passion and dedication, the next generation should demonstrate a similar belief and level of devotion in order to keep up the momentum. In both countries, new champions for the cause started to come on board and

${ }^{347}$ Interview with Dr Ann Skelton dated 28 September 2009. 
take responsibility for progressing and promoting the new ideas, even though they may not have been involved in the initial conceptualising and planning. Rather than trying to source out the 'next generation' in New Zealand and South Africa, as advocacy networks expanded, new individuals with a personal interest and similar passion for the cause appeared to gravitate towards the mission, helping to both grow it and keep it alive. This research found that in both countries, new individuals attached themselves to the mission to transform the existing youth justice systems out of inspiration and support for the work of the pioneering social entrepreneurs. Newcomers to a social entrepreneurial venture tend to take on the role of the 'disciples' which helps to spread and advance the cause.

In New Zealand, key role players took on important positions soon after the passing of CYPF Act in order to embed the new ideas. Although they were not directly involved in the piecing together of the nuts and bolts of the policy and legislation, they had played an influential role in its development, which was recognised by the designers and was reflected in the legislation. Maxwell recalls that she had been asked to comment on the Bill before its final reading as a member of the Council of Civil Liberties. In her submission she stated that she felt there was insufficient time to deliberate on the changes that were being proposed, which would effectively overhaul the existing legislation with limited testing of the new ideas. She stated:
I was enormously supportive of the principles that were involved in the Act but was concerned that rushing it through rather than working it through may be hasty. I now realise that politically this was possibly the only way it could have happened and I am glad it did. ${ }^{348}$

While time to comment and discuss the content of the Bill was limited, Maxwell recognised the need to research the implementation of the youth justice legislation in order to assess how well the principles were being understood and applied. She noted her personal interest lay in the empowerment of families, which attracted her to the new approach:

I was deeply interested in what it meant for these children and I was deeply interested in a process that was so unusual, that was so distinctive and so different and was about empowerment. I have always been a humanist and concerned about involvement, participation and empowerment. These things

\footnotetext{
${ }^{348}$ Interview with Dr Gabrielle Maxwell dated 29 March 2010.
} 
all echoed with me. So I found it exciting, and decided that more than anything else what I wanted to do next was to become somebody who researched this process. ${ }^{349}$

Maxwell approached relevant individuals to undertake research on the new youth justice system soon after it was passed. Her research work with Morris, who she joined forces with early on, soon earned them a place amongst the key promoters of the new system, both in New Zealand and internationally. Their early research involved speaking directly with 'consumers' of the new youth justice system: the families, young people and the victims. They noted: "The interviews focused upon perceptions of, and satisfaction with, both the process and the outcome of the Family Group Conference and Youth Justice proceedings in order to determine whether or not the system made sense to its constituents" (Maxwell and Morris, 1993:16). By creating an accessible framework around the new approach, Maxwell and Morris identified some of the gaps that needed to be addressed in order to fulfil the vision in practice.

Over time, New Zealand's Principal Youth Court Judges have also proven themselves to be important role players in ensuring that the principles of the Act are kept alive. Each of their respective commitments to the values and principles of the Act have been instrumental to their survival in New Zealand's youth justice system. According to Judge Becroft:

In a way, the role of Principal Youth Court Judge became something of a leader in the youth justice sector. They carved out that leadership role that almost in biblical terms in the best sense, almost a prophetic role, where they sold the ethos to the country and they galvanised community. ${ }^{350}$

From the beginning, they have been crucial in garnering support for the new youth justice provisions and ensuring that they are well understood by the judiciary and the community. Judge Mick Brown is remembered by his colleagues as having a special ability to entice others:

Mick Brown was really important. He was the first Principal Youth Court Judge, and he was really a passionate advocate for the new provisions. He

\footnotetext{
${ }^{349}$ Interview with Dr Gabrielle Maxwell dated 29 March 2010.

${ }^{350}$ Interview with Judge Becroft dated 24 November 2009.
} 
went around talking to people trying to calm down some of the hysterical reactions. ${ }^{351}$

Judge Becroft reflected on his experience of being appointed the third Principal Youth Court Judge and the responsibility this role carries in his view. He stated:

I very much see myself as the inheritor of a philosophy that I have to work to champion and continue. But I wasn't one of the original founders of the philosophy or the creators of the philosophy. I would probably be seen as the grandson...I felt a huge obligation I guess as the third Principal Youth Court Judge to guard all that which Judge Brown and Judge Carruthers stood for...So I have come along very much as a 'Johnny-come-lately' whose felt a terrific responsibility to personally live up to their contribution and to work very hard to maintain all that they put in place.... I guess I believe in it because other New Zealanders who I deeply respect have believed in it before me, particularly Mike Doolan, Judge Carruthers, Judge McElrea, Judge Thorburn, Judge Brown, Gabrielle Maxwell. People who I have been greatly influenced by and have, I guess, inculcated in me a set of values that continue. ${ }^{352}$

Like in New Zealand, the need for new people to become involved in sustaining the cause was also evident in South Africa. Skelton noted that there was, "almost like a generational handover" which she stated was "good, because it means you can keep developing". 353 However, she recognised the difficulties in limiting key responsibilities to a small group of dedicated individuals, particularly when wanting to ensure that the message is correctly understood, received and implemented:

A big problem we have is that we are just such a small group who are really such specialists in the country that it does place quite a lot of responsibility on our shoulders...I do feel this sense of responsibility. If you've got knowledge you are duty bound to share it with as many people as possible. $^{354}$

\footnotetext{
${ }^{351}$ Interview with John Angus dated 8 December 2009.

${ }^{352}$ Interview with Judge Becroft dated 24 November 2009.

353 Interview with Dr Ann Skelton dated 28 September 2009.

354 Ibid
} 
Gallinetti shared Skelton's concern that new people coming in might lack the skills and knowledge to do justice to the cause. She stated:
One doesn't want to seem arrogant about one's knowledge about child justice, but it is a particular, long standing institutional knowledge about what is happening across a range of different departments...So those are the types of challenges - whether or not they are going to be able to get the implementation correct. ${ }^{355}$

Frank's views resonated with Skelton and Gallinetti's in terms of whether a small group of champions have the potential to spread the mission and garner support for the new system. She stated:

There are people who have come in slowly who have stuck, like Jacky (Gallinetti) - she came in a little later but is a total champion. There are people who have come and left like Daksha (Kassan), who was very strong for a while and held it together. But I almost feel that given the skills problem in this country, we failed to actually bring a whole generation of people in. ${ }^{356}$

Gallinetti also acknowledged that the new phase in the transformation requires others to pick up the cause for it to take effect: "You know, we have to let it go. This is a new era, we have ushered it in and it must go from here". ${ }^{357}$ While academics and leaders play a crucial role in sustaining the vision through their research, networking and leadership, the key to successful implementation lies in the application of the principles and procedures by the practitioners. Without a next generation of strong supporters and advocates, a mission risks becoming offset by government control, bureaucratic procedure and decision-making based on available funding and resources. According to Becroft:

These are all the dangers of a second generation. It's like any revolution I suppose. The visionaries are gone and the maintainers are there, and there

\footnotetext{
${ }^{355}$ Interview with Dr Jacqui Gallinetti dated 15 October 2009.

${ }^{356}$ Interview with Cheryl Frank dated 28 September 2009.

${ }^{357}$ Interview with Dr Jacqui Gallinetti dated 15 October 2009.
} 
can be a loss of energy, and become less principled, and we become more susceptible to swings. ${ }^{358}$

While the key policy advocates continue to drive the cause for as long as possible, over time they may not have the capacity or energy to sustain the same level of involvement. As the case studies in this thesis illustrate, policy transformation can take many years, and fresh blood is required to keep up the momentum. Furthermore, as a cause starts to shape up and take root, the process expands and more people need to assist with growing the vision. SlothNielsen acknowledged: "I think the advocacy area is never going to go away, but we also need to breed a new generation now. Ann and I are getting tired ". ${ }^{359}$ Sloth-Nielsen's experience resonates with concerns expressed by Jerr Borshee in the attempt to sustain social entrepreneurial changes over time, particularly when some of the key ingredients which help support the transformation dissipate over time: "The initial band of dedicated volunteers and employees might be burning out. Government support for a project could be waning or the cost of delivering services escalating dramatically" (Borshee in Nicholls 2006:356).

\section{Conclusion}

In conclusion, this chapter demonstrates that the processes of youth justice transformation in New Zealand and South Africa represent examples of social entrepreneurship. In framing the processes this way, it is noted that while social entrepreneurship may be made up of the passion and drive of motivated individuals, it is through the combining of their strengths that a social entrepreneurship venture can start to gain momentum and effect change. This chapter also illustrates that successful social entrepreneurial ventures require government support in order to implement alternative strategies and systems. Without this government support, social entrepreneurial initiatives can remain limited to pockets of activities (such as pilot projects) that may only endure for as long as passionate individuals drive them.

The challenges to implementation that both New Zealand and South Africa faced after their new youth justice legislation came into force reveals the difficulties with maintaining high levels of enthusiasm, integrity and support for a set of principles over time, particularly when funding priorities shift. While governments may initially play a supportive role in implementing the scaffolding for the new approach, such as strategic policy and legislation, if genuine support for the principles fades and dedication to build upon the framework

\footnotetext{
${ }^{358}$ Interview with Judge Becroft dated 24 November 2009.

${ }^{359}$ Interview with Dr Julia Sloth-Nielsen dated 16 October 2009.
} 
diminishes, the reality risks becoming a hollow reflection of the intentions. As both countries illustrate, this is often the result of converting the social entrepreneurial venture into rigid, bureaucratic procedures (Mulgan in Nicholls, 2006:92) which revert back to quantifiable outputs rather than qualitative, experiential outcomes for the consumers that reflect improvements to the social status that the social entrepreneurs worked to change (Nicholls in Nicholls, 2006:30).

In order to counter the forces that undermine the initial processes of transformation, Drayton considered the reproduction and proliferation of social entrepreneurial qualities is essential to effecting widespread change. He noted: "Given the results-based power of this transformation of the citizen sector, more and more local change makers are emerging. Some of these learn from and later expand the pool of leading social entrepreneurs" (Drayton, 2006:7). Without ongoing strong champions to sustain the mission, government agencies, responsible for implementing the practices and managing the budgets, risk reverting back to easily controllable measures. Until this risk is significantly reduced, processes of transformation will be incomplete. 


\section{Chapter 10}

\section{How policy transfer contributed to youth justice transformation in New Zealand and South Africa}

When altering their domestic youth justice systems, both New Zealand and South Africa drew on experiences and developments from within and outside their boundaries, shared their experiences internationally and illustrated how their system transformation fitted within universal theoretical frameworks for children's rights and restorative justice. This sharing of experiences expanded the impetus for change from responding to national needs to supporting international youth justice movements. In developing practical policies and procedures that reflect a shared set of core values and principles, New Zealand and South Africa have either directly or inadvertently assisted with the development of policy and legislation in other parts of the world, thereby allowing for the dispersion of processes that better align with international standards through policy transfer mechanisms. This chapter reveals how policy transfer threaded through the approaches taken in both countries when constructing their new youth justice systems, and how this has enabled them to contribute to a global movement to adopt youth justice approaches that reflect international standards for youth justice and restorative justice principles.

\section{Defining policy transfer}

According to Keith Dowding, policy transfer is "the process whereby knowledge, policies, or administrative arrangements shift from one nation or policy domain to another" (2009). Like social entrepreneurship, policy transfer is not a particularly recent or unusual concept, but some have argued that the phenomenon has become more regular and rapid in the past two to three decades, largely thanks to advances in communication technology such as the internet (Dolowitz and Marsh, 2000). Dolowitz and Marsh (2000) ask two key questions when analysing policy transfer processes: "What was transferred?", and "What degree of transfer occurred?". They propose that degrees of policy transfer can be analysed using a continuum from 'lesson-drawing' to 'coercion'. 'Lesson-drawing' is when policy makers look to policies elsewhere to help them respond to a certain problem or need that must be addressed in their context (Rose, 2005). According to Rose (2005:23): “Lesson-drawing expands the scope for choice in the national political agenda, for it adds to proposals generated by domestic experience the stimulus of examples drawn from foreign experience". In its most pristine 
form, lesson-drawing is a voluntary process whereby policy makers seek out viable strategies that have been tried and tested to apply in other contexts that they believe they could apply in their own context.

As the name suggests, 'coercive' transfer, on the other hand, is when states or policy makers are compelled to adopt certain policies that have been developed and applied elsewhere to address a problem or need. Coercive transfer is common within international community networks, where nation states have become bound by certain international treaties or conventions which include a set of standards, such as the UNCRC. Scholte (1993:69) notes that these standards often "take the shape of explicit regulation: i.e. they are officially formulated, administered and monitored, often through intergovernmental organisations". He states: "Nowadays such directives are frequently grouped into sets of rules and procedures that define a framework of acceptable behaviour regarding a specific issue in international relations" (Scholte, 1993:69). Nations struggling to find their own strategies to implement these regulations make use of examples elsewhere, which helps to demonstrate their commitment to and compliance with the international standards.

Dolowitz and Marsh (2000) suggested that analysing policy transfer along a continuum from lesson-drawing to coercion helps to identify different motivations driving the policy transfer. It also helps to unpack the extent to which the 'borrower' understands the context from which they are adopting the policy. Other notions in the policy transfer spectrum include 'copying' which involves duplicating an existing policy by another context, 'emulating' certain policy or programme ideas, and 'inspiration' "where policy in another jurisdiction may inspire a policy change but where the final outcome does not actually draw on the original" (Dolowitz and Marsh 2000:13). Stone (2001) described other iterations of policy transfer such as policy diffusion, which refers to the slow transfer of policy ideas from one context to another over time, and policy convergence, where different contexts adopt policies which ultimately resemble each other, despite any deliberate process or intention.

While discussions around policy transfer and related ideas have generally revolved around policy exchange between nations, policy transfer can also happen at other levels. For example, national policy makers may look to domestic or localised strategies they can draw lessons from to influence policy change. Communities within one country might be interested in policy or practice examples from specific communities in another country. Alternatively, a 
nation might look to solutions from a local community in another country, rather than drawing from their broader national policies (Scholte, 1993; Dolowitz and Marsh, 2000:12).

\section{'Perfect' versus 'bounded' rationality}

According to Klinger (2006:59) “Adoption of innovations is best viewed as a complex process involving organisational learning and knowledge management". Dolowitz and Marsh cautioned against some of the main pitfalls of policy transfer (2000). In their view, policy transfer failure is often the result of policy borrowers having limited knowledge of the context they are borrowing from. In particular, the various local nuances, circumstances and conditions which differentiate one context from another, and can possibly make the policy less suitable in the borrower's context. Following Herbert Simon (Simon, 1972), they contrasted 'perfect rationality' with 'bounded rationality'. Perfect rationality means that the policy borrower has fully considered the context that they want to borrow from, and the appropriateness and relevance of the policy to address their needs. However, Dolowitz and Marsh (2000:14) believe that decisions around policy transfer are seldom based on perfect rationality, and are often adopted as an expedient means to an end, based on bounded rationality. Bounded rationality means that the borrower adopts a policy without fully understanding the context and circumstances of where it was originally applied, and/or without considering the possible shortcomings in the new context. Simply because a policy is appropriate and adequately meets the needs in one context does not automatically mean that it will succeed in another context, even if the problem being addressed is similar.

As discussed in Chapter 7, New Zealand developed its youth justice policies in the CYPF Act reasonably independently to what was happening in the international youth justice movement in the years leading up the launch of the UNCRC. Therefore, the changes to New Zealand's youth justice system were not driven by a moral obligation or coercion to join in with the rest of the world. Rather they were born out of a need to address domestic concerns largely articulated by the local indigenous community. Nevertheless, certain aspects of policy transfer are identifiable in New Zealand's process of youth justice transformation which can be located at different points of Dolowitz and Marsh's policy transfer continuum. By the 1980s, policy makers in New Zealand were starting to better consider its national cultural complexities and to think about how these should be addressed through social policy and practice. There were a few forces at play during this period which started to converge. At an international level, 1979 was declared the International Year of the Child. This provided a 'universal umbrella' for considering the needs of children. While it might not have been a 
coercive force for New Zealand, it appears to at least have been a persuasive one, having been mentioned as one of the reasons for reviewing the existing Children and Young Persons Act of 1974 (Department of Social Welfare, 1984). Internally, New Zealand had already started recognising the shortcomings of existing youth justice and child protection policies, with child abuse being exposed in both family homes and welfare institutions. The need to address child welfare policy in general had clearly emerged. It was also increasingly clear that the New Zealand children and young people most affected by the existing policy and practice were Māori. Existing child welfare policies did not consider indigenous customary approaches to support children's development and social integration. The combination of internal pressures and international influences allowed policy makers to negotiate the various policy options and combinations available to them both internally and externally. With the voice of Māori causing a stir that could not be ignored by the government of the day, policy makers turned to local indigenous practices for inspiration on how to devise policy that would better respond to the needs of the indigenous community while still being nationally relevant and appropriate.

At the same time, Doolan, who was appointed the youth justice policy lead for the review of the Children and Young Persons Bill in 1987, was drawing lessons from policies being implemented in Canada, the United States and the United Kingdom, which he observed during his study tour. He was strongly influenced by the idea of moving away from a welfare model for responding to children in conflict with the law, to applying a justice model that concentrated more directly on offending behaviour, instead of making broad assumptions about the possible welfare needs of all children who offend. This was pivotal in New Zealand's process of youth justice transformation that included the application of a youth justice approach inspired by western models observed during his international tour.

According to Dolowitz and Marsh (2000:17), "If policy transfer is undertaken during periods of social, political and economic stability within a nation, such transfer is likely to be voluntary. However, if there is a form of political crisis, then policy transfer is likely to have some coercive elements". New Zealand recognised the shortcomings of its existing child protection and justice policies to address the needs of children, young people and their families at a time when there were increasing rumblings particularly related to the historical and systemic injustices towards Māori that had systematically undermined the spirit of the Treaty of Waitangi. Arguably the greatest power of coercion in New Zealand's overhaul of existing welfare policies was from Māori when they recognised the risk to their cultural 
integrity if child welfare approaches were to be further professionalised. Māori took advantage of the opportunity to stymie the initial tracking of the Children and Young Persons Bill in the mid-1980s. They noted that the Maatua Whangai policy and acknowledgment of the recommendations from the Māori Advisory Committee in the Puao-Te-Ata-Tu report were insufficient to address the failures in existing policy for Māori, and that Māori would not be satisfied until their needs were recognised in legislation.

While New Zealand policy makers wanted to address Māori concerns, they were also subject to government pressures to avoid creating separate or parallel justice systems, and to design a system that could universally address to the needs of all New Zealanders. Similarly to New Zealand, South African policy makers also wanted to ensure that their design could accommodate local experience and indigenous needs and customs, which had continued to be informally run at a community level, including during the apartheid years. Therefore, both countries drew lessons on local experiences when developing the new legislation. Pinnock explained how insights into local, indigenous practice helped to give direction to some of the early shaping of South Africa's new youth justice system:

We knew what was coming up at a community level, which was why that process of putting the legislation together was interesting, because we were taking what we were seeing on the streets and trying to bring it up in this legislative process. And then we were taking history and anthropology also and putting it together and trying to formalise it into a legislative process. ${ }^{360}$

Both cases illustrate a voluntary process of lesson drawing, both from external policies being implemented elsewhere, as well as from policies and customs which existed internally at a local community level. These policy transfer processes demonstrate what Stone (2000:2) described as "the logic of choice in selection of policy ideas, the cognition and interpretation of circumstances or environment and (bounded) rationality in imitation, copying and modification by decision makers". The process started with a need to address "dissatisfaction in the status quo" (Dolowitz and Marsh, 2000:14) driving the voluntary process of seeking out existing policies that could assist in addressing national concerns.

While noting that policy transfer usually involves a 'borrower' and a 'lender' Dolowitz and Marsh (2000) noted that these identities are fluid and interchangeable. New Zealand's youth

${ }^{360}$ Interview with Don Pinnock dated 2 March 2011. 
justice system, including the youth justice FGC, became recognised as a unique, innovative model created out of inspiration from local and international contexts, emulation of the emerging justice approach to respond to children in conflict with the law and modification of local indigenous practices to meet the expressed youth justice needs within New Zealand's domestic context. Soon after implementing the youth justice FGC model, New Zealand moved into the position of becoming the 'policy lender', rather than the 'borrower'. Framing youth justice FGCs as an example of restorative justice in practice helped make the approach more accessible to youth justice policy makers and advocates in other countries. In fact, New Zealand government agencies were still working through the operational procedures for FGCs when policy makers from other countries started showing interest in the model. The fact that FGCs were designed to allow for flexibility and responsiveness to the needs of the participants on a case by case basis provided leeway for other countries to experiment with the operational details. This flexibility arguably made the approach even more attractive to external policy makers, as it emphasised the core set of values and principles which resonated with international standards for children's rights to address youth justice matters. At an international level, these values and principles had become binding and therefore coercive for the nations who had signed the UNCRC. Maxwell recalled her role in the international dissemination of New Zealand's youth justice model:

The Australian trip was the first of many experiences where I was invited to foreign countries or foreign jurisdictions to talk about what was happening here. It became the start of a change process in those countries, which has succeeded to a greater or lesser extent. It was about being sort of a seed scatterer' really. The ideas were around. Everybody had them, and read the influential books and the UN Convention. Braithwaite's book was widely read Howard Zehr's work was widely read. Ours was the first real live example of the process in action...I went to twenty-five different states over those years, because people were reaching out. ${ }^{361}$

According to Angus, the former Children's Commissioner, "I think that New Zealanders do get proud of the things we've done that people copy overseas. There has been a lot of copying of the family group conference, and I think lots of people think it's a really good idea". 362 Maxwell and Morris were celebrated both locally and internationally for articulating the

\footnotetext{
${ }^{361}$ Interview with Dr Gabrielle Maxwell dated 29 March 2010.

${ }^{362}$ Interview with John Angus dated 8 December 2009.
} 
parallels between New Zealand's FGC and restorative justice principles. They became instrumental in both promoting a model of restorative justice that could be applied elsewhere, as well as drawing on similar practices from other parts of the world to increase the practical application of restorative justice in different contexts. They were widely published and were asked to speak at a number of conferences and forums about New Zealand's youth justice approach. It was good timing for New Zealand to become a 'lender' of its pioneering youth justice model where other nations might have been scratching their heads for ideas on how to meet the international standards for youth justice.

South Africa was one of the countries that benefitted from New Zealand's youth justice model. It took on the role of 'borrower' of international policy, particularly in the early stages of its youth justice system development. Concerted efforts to transform existing youth justice policies in South Africa started to gain traction during a period of political crisis, when the country was going through a process of social upheaval and national transformation following the end of apartheid. After many years of isolation from the international community, South Africa found its place in the international community and signed a number of international treaties and conventions they had refrained from during the apartheid years. This included, as noted previously, the binding principles of the UNCRC. In so doing, the government showed a commitment to implementing policies that would meet its new found international obligations and enhance its global acceptance.

A group of policy makers and child justice advocates had already started to unite around the cause for children in conflict with the law, recognising the urgent need to change the existing procedures and conditions in South Africa. In addition to experimenting with programmes that would increase options for diversion from courts and prison, they had started to look at policies, programmes and processes elsewhere from which they could draw lessons, ideas and inspiration for developing and framing their own policy and legislation. Muntingh recalled his interest in Zehr's work after a visit to the United States in the early 1990s, when NICRO and Lawyers for Human Rights had informally started implementing diversion programmes. Zehr's work on restorative justice started having an influence on the thinking of South African child justice advocates, which led them to seek out examples of restorative justice practices that would suit South Africa's context and assist in their process of developing a new child justice approach. As noted previously, this led Pinnock to put out his feelers internationally using rapidly developing technology for global networking, to find examples of restorative justice approaches that would be suitable for South Africa's context. As this 
thesis identifies, this resulted in the connection to New Zealand's youth justice system via Maxwell.

South Africa's connection to New Zealand is arguably the most referred to aspect of policy transfer that took place in the early stages of South Africa's child justice transformation process. Research participants from South Africa identified several ways in which New Zealand's youth justice system helped to provide answers for what they were looking for to address their needs. Following Pinnock's contact with Maxwell, the policy transfer process appears to have quickly become quite intimate and direct, starting with Maxwell's visit to South Africa. Pinnock described the importance of Maxwell's visit to South Africa at the time of conceptualising the legislation. He stated:

(Maxwell) was hugely useful, because she could give us the entire New Zealand perspective. It jumpstarted our process quite rapidly...She came in with a package of concepts and ideas that were really useful. ${ }^{363}$

From the earliest opportunity, Maxwell worked closely with Skelton, Pinnock and ShapiroLiu in assisting to draft up some of the original core ideas and processes. Soon after, new momentum in the youth justice development process was gained through the setting up of the IMC, which called for a specific FGC pilot project. This led to the visit of the South African delegation to New Zealand which included Skelton and Frank, giving them an opportunity to observe New Zealand's youth justice system in practice first hand in order to bring home their findings and consider how they could contribute to the development of South Africa's child justice system. Mike Batley who had started to become increasingly interested in the opportunities for restorative justice in South Africa recalled:

The IMC eventually asked us if we would house the project on family group conferencing, which used the New Zealand model specifically. We would then test it using the New Zealand model. And it was through this process there was actually a team who visited New Zealand to look at how it was done. Somebody from New Zealand came here and Howard Zehr all as part of that process, so that was how we were exposed to restorative justice and how it was being implemented in New Zealand. ${ }^{364}$

\footnotetext{
${ }^{363}$ Interview with Don Pinnock dated 2 March 2011.

${ }^{364}$ Interview with Mike Batley dated 30 October 2009.
} 
Although South Africa considered youth justice policies from a number of jurisdictions when conceptualising its own youth justice system, the lessons drawn from New Zealand were highly influential in South Africa's design process. This was particularly in terms of restorative justice opportunities for diversion which enhanced community and family involvement while also making allowance for South Africa's cultural diversity. Frank described the influence of her trip to New Zealand as follows:

They organised for us to see as much of the system as possible, including sitting in on family group conferences, sitting in on court, going around with the cops, seeing intervention programmes... While we did that we also visited universities and made presentations about what we were dealing with... We spent time talking to facilitators and talking about why they do the work they do, and why they are committed to these processes...(as well as) why it's so important for the parents and grandparents to be there...I became convinced for the first time about restorative justice coming back from that. I also had cautious optimism about how traditional justice mechanisms could be integrated. I certainly came back with a feeling that this could work for us. ${ }^{365}$

Judge Becroft noted his concern that some 'borrowers' of New Zealand's youth justice policies had not captured the full range of benefits New Zealand's system had to offer. While he supported the distribution of the FGC model, he believed that a number of borrowing nations applied bounded rationality in terms of just focusing on the FGC. As a result they often missed the greater opportunities for diversion offered by New Zealand's police youth aid sector. Instead, many jurisdictions started investing resources into FGCs for minor offending, rather than for the more serious offending for which they were intended in the New Zealand design. He noted:

Our system is often 'marketed' as an 'FGC system'. That's misled a lot of the world I think in that FGCs are used for some pretty minor offending really. I don't think people realise that they are reserved for the top end, and they are mandatory. That's because we haven't 'marketed' the role of a specialist uniformed police constabulary who deals with young offenders. I know of no country in the world that's got such a specialist highly trained

${ }^{365}$ Interview with Cheryl Frank dated 28 September 2009. 
force to deal with young offenders. And that's what we don't publicise. We don't let that be known to the rest of the world. ${ }^{366}$

Judge Becroft's point suggests that what other countries are missing from New Zealand's youth justice system is the greater gradation of intervention. For example, in New Zealand the police youth aid sector initiatives mean that the majority of youth offenders can be diverted without any need to be referred to an FGC. In his view, if more countries adopted the approach used by New Zealand's youth aid sector, they would increase opportunities to divert minor offending, and reserve higher levels of intervention like the FGC where there is greater need.

As intrigued as South African policy makers were with New Zealand's youth justice model, there were significant contextual differences between the two countries, particularly in terms of South Africa's transitional government structures and bureaucracies as well as the shortage of adequate human resources. These circumstances made it difficult for South Africa to copy New Zealand's model directly. The SALRC recognised these differences when developing the legislation and consulting with key groups internally. After a process of consideration, deliberation and modification, the policy makers adapted New Zealand's model to suit South Africa's needs and reality. In the end, South Africa did not make FGCs mandatory or reserve them only for the most serious offending. South Africa's adaptation of FGCs in its youth justice system as well as its decision not to give police more responsibility in terms of running diversion programmes as in New Zealand was not a question of 'uninformed transfer' or 'incomplete transfer', which Dolowitz and Marsh argued was likely to result in failure (Dolowitz and Marsh, 2000:17). Rather, the policy makers followed a rational process, weighing up the pros and cons of the policies they wanted to borrow. They were tasked with designing a system that would be feasible and acceptable to both the government responsible for implementing the youth justice system as well as the general South African public. The SALRC, after giving the model extensive consideration, did not believe the government would be able to resource a child justice system with FGCs as a mandatory central process. ${ }^{367}$ They wanted to retain the option for FGCs and believed that it added value to the design of South Africa's child justice system. However, they did not want the limitations in implementing New Zealand's FGC model to restrict diversion opportunities for children in conflict with the law in South Africa. It is arguable that South Africa did not apply a process

\footnotetext{
${ }^{366}$ Interview with Judge Becroft dated 24 November 2009.

${ }^{367}$ South African Law Reform Commission Juvenile Justice Report-Project 106 - July 2000:9
} 
of 'perfect rationality' when borrowing from New Zealand's youth justice policy approaches, as policy makers did not set out to discover everything possible about New Zealand's context before considering the application of its approaches in South Africa. However, South Africa was clearly inspired by and learned lessons from New Zealand's youth justice approach. It borrowed those aspects of New Zealand's system they believed would help them meet the restorative justice principles underpinning their new system, and would help to fulfil international obligations for youth justice after signing the UNCRC.

As with New Zealand, the development of South Africa's child justice system soon grabbed the attention of youth justice policy makers, academics and advocates internationally, even some years before the legislation had been formally drafted. This was largely as a result of a commitment to a set of values and principles by policy makers and child justice advocates that were taking root within the international children's rights and restorative justice communities. These networks had been growing in strength and membership since the early 1990s. Pinnock, who played a significant role in linking in with the growing international network, recalled the reciprocal interest in youth justice thinking and approaches that were developing and taking shape:

When Rosemary and Ann and I were wandering around the world, and giving talks in Germany and Holland and places like that, people were aghast! They had never heard of legislation like that. It was so exciting! We were at the cutting edge of juvenile justice. And the reason was that we were taking indigenous systems and formalising them into western concepts of legal process. I remember we gave a talk in Germany, and people were asking 'How did you think of this?' 'Where did it come from?' 'We've got these problems. Will you come and help us with our legislation?' The whole established western world was asking for help from this little country in the south of Africa in terms of their youth justice stuff. We had a lot of exposure... We were getting information, but we were also being asked to talk. At that time, the juvenile justice stuff going on here was at the forefront of the debates going on worldwide in the venues that we were circling in American and European venues. ${ }^{368}$

\footnotetext{
${ }^{368}$ Interview with Don Pinnock dated 2 March 2011.
} 
Like New Zealand, South Africa has been able to share ideas at international forums on strategies for responding to children in conflict with the law. As a result of South Africa's advances in its youth justice processes, other African nations started turning to South Africa for ideas and inspiration. Given the delays before South Africa's youth justice system came into force, some African nations began implementing aspects of South Africa's proposed child justice policies even before the South African government had passed Child Justice Act of 2008. Sloth-Nielsen reflected:

\section{I do think that we managed to keep some kind of a distinctive system that can be called a juvenile justice system, and that we can hold up, and have held up, because our system has been borrowed all over the continent. In fact it's operating in some other African countries already. So I think there is something worthy of an African reality. ${ }^{369}$}

Therefore, South Africa also soon shifted from being a 'borrower' to a 'lender' of its youth justice policy. While policy and legislation was being drafted and promoted in South Africa, key role players including Skelton and Sloth-Nielsen in particular started taking on roles and projects that would further extend the influence of their ideas internationally, as well as increase their opportunities to directly tap into relevant debates and discussions that could influence and enhance domestic developments. They have both played important roles in United Nations-driven projects. These include the United Nations Development Programme (UNDP) Child Justice Programme in South Africa where Skelton was appointed director, and the Juvenile Justice Manual and Toolkit for the United Nations Office for Drugs and Crime, which both Sloth-Nielsen and Skelton contributed to. Over the years, their work and influence has helped to elevate the importance of child justice on the African agenda. For example, they were both part of a conference advisory team for the Kampala Conference titled Deprivation of Children as the Last Resort organised by the African Child Policy Forum and Defence for Children International held in Uganda in November 2011. The purpose of this conference was to continue to help African nations to:

Contribute to the improvement of laws, policies, systems and procedures in the justice system in Africa when it deals with children by awareness raising on the gaps in the child justice system in Africa among policy makers, CSOs, academia, and other relevant stakeholders. Identification and

\footnotetext{
${ }^{369}$ Interview with Prof Julia Sloth-Nielsen dated 16 October 2009.
} 
sharing of good practice models and concrete actions in the justice system when it deals with children and promotion of learning and linking among African states and developing, recommending and advocating for the guidelines on child friendly justice in Africa to be endorsed and enforced by African States.

The developments in South Africa were of particular interest to other African nations given the responsiveness to indigenous African customs and needs, which perhaps resonated more closely with them than existing western models. Many of these African nations, including countries like Namibia, Tanzania, Kenya and Uganda would also be coerced into improving their existing youth justice laws as a result of their binding commitments under the UNCRC which all their governments had ratified. These obligations were further reinforced on the continent through the launching of the African Charter on the Rights and Welfare of the Child in 1999, which included provisions for dealing with children in conflict with the law. South Africa's Child Justice Act has helped to provide an example of how child justice policy can be developed in the African context within a framework which respects international standards for youth justice.

\section{Conclusion}

Both New Zealand and South Africa's experiences of youth justice transformation demonstrate the advantages of creating networks and advocacy coalitions to shape and advance their youth justice approaches. In addition to their internal networks, key policy makers and activists connected with international networks that either shared similar values and principles or had implemented strategies that appealed to them. The research participants revealed how they used their skills and abilities not only to draw from lessons that accumulated through international networks, but also to make sense of the learning and consider the relevance and appropriateness for the context to which the policies and lessons might apply. Despite opposition and challenge, a small group of social entrepreneurs in both New Zealand and South Africa found each other, rallied around the cause and drove successful campaigns. These campaigns not only resulted in an overhaul of the internal systems for youth justice, but have had a ripple effect on other countries around the world. Young (2006:57 in Nicholls) explains, "small groups of committed people can find points of powerful leverage - and achieve a tipping point". The fact that both countries have become youth justice policy lenders to other countries demonstrates how their experiences have 
helped to strengthen opportunities to develop youth justice policies around the world that both meet the international standards for youth justice and encourage the application of restorative justice principles in other youth justice systems. 


\section{Chapter 11 \\ Conclusion}

Youth justice developments have increasingly emphasised society's responsibility to protect children, encourage their participation and help children to reach their potential. Pro-active, holistic, restorative approaches to addressing juvenile delinquency have been found internationally to result in the best outcomes for children, young people, families and communities. These ideas and principles contributed to the development of both New Zealand and South Africa's youth justice systems. This research explored and compared the experiences of New Zealand and South Africa's youth justice reform by asking two key research questions discussed below.

\section{What were the key conceptual influences that shaped youth justice transformation in New Zealand and South Africa?}

At the heart of the youth justice policy making processes in both countries was a powerful human rights agenda which permeated the thinking of the individuals in places of influence, most notably the participants in this research. The research found that policy makers were committed to the core values and principles that reflected international standards for children's rights at a time when both countries were going through processes of national change to address social imbalances and historical injustice. Given the damaging effects of colonisation on indigenous and non-European populations, changes to both youth justice systems sought to make a contribution to redressing the imbalances of the past. This was not least of all because the problem of children in the criminal justice system had become both a symptom and a symbol of racial imbalances in both countries. The core values and principals formed the foundation for both pieces of youth justice legislation.

The discussion on the selected social psychological theories in Chapter 4 demonstrated some of the impact of social injustice and exclusion on children and young people's development which undermined the role of family and community. This signalled the importance of creating strategic and operational policy settings that involve families and communities in decision-making about their children's wellbeing and enable a strength-based approach to increase resilience and children's pro-social development. 
The youth justice changes in both countries were also set against a growing consciousness and awareness of indigenous culture and traditions, accompanied by movements to better integrate these traditions into mainstream society. In New Zealand this was the Māori renaissance; in South Africa, the African renaissance. Policy advisors in New Zealand sought to incorporate Māori views while forming their policies. The intention was to support families and communities to apply their customs and traditional knowledge to respond to children in conflict with the law in a way they felt was safe and appropriate. In South Africa, while human rights considerations were central to most social policy reform at the time the youth justice legislation was being drafted, the Truth and Reconciliation Commission was also promoting the African indigenous notion of $u b u n t u$, in the hope of uniting South Africans and reminding them of their common humanity and inter-connectedness. This resonated with policy makers working on youth justice changes at the time who wanted to infuse the principles of $u b u n t u$ into their youth justice legislation.

While policy makers drew on indigenous, communitarian concepts when designing their youth justice systems, the approaches were designed to be flexible and responsive to any culture within both countries' diverse and multi-cultural societies. The aim was for the approaches to be relevant, recognisable and applicable to indigenous populations in both countries, but at the same time transferrable to any cultural settings because the underlying principles were essentially of universal importance. As a result, neither youth justice system's legislation refers to specific indigenous practices, even though, comparisons are often drawn between youth justice principles and approaches and traditional indigenous customs to demonstrate their relevance to these groups (Tauri, 1998).

The research findings demonstrate that a holistic approach to youth justice should include an understanding of the factors which contribute to the offending as well as the most suitable responses to repair harm to victims and prevent further offending. These complex considerations and objectives re-emphasise the need for flexibility in responses to offending by children and young people. Practitioners do not need to know the intricacies of each situation, but they should possess the skills to encourage participants to engage in youth justice processes within the overarching legislative principles. When participants and practitioners are guided by the core principles, a number of relevant responses are possible (Maxwell et al, 2004). This research highlights that the common factors which shaped New Zealand and South Africa's youth justice systems were: 
- the need to enhance social justice

- the need to support children and young people's development and reintegration in the community

- the influence of restorative justice principles that involve those affected by the crime (victims, offenders, their families and communities) in decision-making and finding solutions that will repair the harm, and

- the influence of indigenous cultural perspectives

Both New Zealand and South African policy makers are proud of creating youth justice systems based a particular set of values and principles. However, neither country has been able to fully realise their goals to empower families and communities to support better outcomes for children and young people in conflict with the law (especially indigenous families and communities). The risk is that the people close to the process lose faith in the youth justice system. Both countries have faced two key criticisms of their youth justice approaches that have threatened to derail their success. One criticism is that the existing youth justice systems do not adequately punish or deter prolific and serious young offenders. ${ }^{370}$ The research found that the participants maintained that it is always preferable to respond to children and young people in a way that takes into account their vulnerability and evolving capacities while addressing the factors that contribute to their offending behaviour. They believe that empowering families and communities to support children and young people's reintegration will ultimately lead to better, long-term results than separating them from their families and detaining them in unfamiliar environments where they mix and learn more criminal tricks from other young offenders.

The other criticism is that many families and communities do not have the experience, tools or ability that best meet their children's needs without significant intervention. This concern is often raised in relation to families who suffer from factors such as chronic unemployment, limited education, drug and alcohol addiction and histories of criminality and imprisonment all factors that have been identified as affecting children and young people's development in this thesis. The concern is that these negative family conditions amplify children's vulnerability and ultimately increase the likelihood that these children will engage in criminal

\footnotetext{
${ }^{370}$ This was a particular concern for De Lange, in South Africa who stymied the process of change for a number of years. It has also been a key driver of opponents in New Zealand. This has recently resulted in harsher penalties for a wider range of offences which can now affect children from a younger age in New Zealand.
} 
behaviour. ${ }^{371}$ Many disadvantaged families and communities agree that their social circumstances limit their skills and ability to care for their children. They argue that they need support and easy access to relevant services to strengthen their capability to enable better outcomes for their children and young people. If the state invests in processes that strengthen and support families' abilities to raise their children, rather than in mechanisms that take over the role of families and communities, this may generate enduring results that could reverse negative intergenerational cycles. As Garbarino (1982:219) noted:

$$
\begin{aligned}
& \text { If the policies that guide actions by both public and private endeavours are } \\
& \text { to be truly and actively pro-child, then policy makers must consider } \\
& \text { carefully the potential effects of their decisions on the parents' ability to } \\
& \text { provide for their children's physical needs and to maintain enduring } \\
& \text { supportive relationships that are necessary for emotional and social } \\
& \text { wellbeing. }
\end{aligned}
$$

Part of the problem is that government officials tend to develop stringent bureaucratic procedures and standards that can fit within often unpredictable budgets. These procedures help government officials maintain control and oversight over the processes, indicating governments' reluctance to hand power over to families and communities. Building on existing research is needed to identify processes that achieve the best outcomes for children and young people who offend from the most disadvantaged families and communities, to know how to support them to address their offending and to reintegrate them into the community. Incorporating more organic locally defined processes in evaluation procedures and outcomes may increase family, community and victim involvement, which can become limited when boxed in by bureaucratic and administrative process. According to Graser:

We need to go back to the founding principles. They worked for years, and everything was developed very well...It seems to me the process has to crash before people realise we've got to do something about it - we have to revive it. $^{372}$

\footnotetext{
${ }^{371}$ In New Zealand, this was the main opposition to the FGC approach. In South Africa, this is identified as a particular concern in communities which still struggle from high levels of poverty and dislocation, exacerbated by the major social impact of HIV-Aids which has contributed to a growth in the phenomenon of child headed households.

${ }^{372}$ Interview with Dr Graser dated 5 May 2012.
} 
Even with better support for disadvantaged families, there is still a need to reduce endemic disparities in society which continue to marginalise particular social groups. For New Zealand, the divide between the Crown and Māori world views and lifestyles still creates social strain. In South Africa, while the legacy of apartheid still affects social dynamics and race relations, capitalist forces are now driving a large wedge between the very rich and very poor irrespective of race in South Africa.

\section{What do both countries' experiences of youth justice transformation reveal about the role of individuals, advocacy coalitions and international influences in shaping policy and practice?}

The study reveals how the youth justice policy direction in both countries was strongly steered by key passionate individuals in places of influence. Participants in both countries described their commitment to changing the status quo following their exposure to the inhumane conditions experienced by children and young people in conflict with the law. These experiences prompted them to promote policies that divert children from the justice system and prevent re-offending while still holding children and young people to account for their behaviour and encouraging them to repair the harm. They resisted opposition to their approach and joined forces to develop convincing arguments for their position. This research found that these qualities resonated strongly with the criteria used for identifying social entrepreneurs. Importantly, research participants from both countries acknowledged that uniting with other key role players around a shared cause to improve outcomes for children and young people in conflict with the law was vital to their success. Although there may have been some ideological differences between the role players, their commitment to a common set of principles helped them to create relationships and working groups that gave traction to their youth justice movements. In tracing back the genesis of international standards for children's rights it was interesting to note that the initial idea to generate a set of children's rights started with one woman, Eglentyne Jebb. Jebb, following her exposure to children during the war, was determined to develop universal measures that would ensure children's protection and survival (Culley, 2009). Her drive and passion for this cause ultimately influenced changes to both New Zealand and South Africa's youth justice systems.

The importance of government support to advance social entrepreneurial ventures was also confirmed. However, even with government support, there is a need to continuously entice new individuals to the cause who share and support the vision if the underlying values and 
principles are to endure. The research describes the challenges of sustaining the social entrepreneurial ventures and provides insight into ways to overcome these challenges. It emphasises the importance of attracting new generations to the cause who share the vision of the previous generations. This includes government officials responsible for drafting policy and legislation, and practitioners who bring the policy and legislation to life. Of course, changes and adjustments are needed over time to allow systems to adapt to contemporary social contexts. Robust systems of accountability with committed governance structures are needed to oversee and guide the processes as well as to respond to critique from independent monitors. Such mechanisms help to ensure that the systems are being run honestly and with integrity.

While committed individuals joined forces to advance youth justice transformation in New Zealand and South Africa respectively, policy transfer from internal and external sources helped to stimulate and give direction to the youth justice systems in both countries. Policy transfer was also found to provide a point of convergence and learning between New Zealand and South Africa, particularly when South Africa was developing its youth justice system. The experience of policy transfer between the two countries demonstrated how one country can borrow policies from another and adapt them to its own domestic realities and needs. Using the two research cases as examples, while South African policy makers drew lessons from New Zealand's youth justice approach, they were able develop processes that better suited their circumstances given some of the unique social experiences that lingered from the previous apartheid regime. Therefore, New Zealand's policies helped to inspire South Africa's process of youth justice transformation rather than shape it.

Sharing ideas internationally to promote a common universal vision for youth justice illustrates how social entrepreneurship ventures are not limited to space and time, but can also drive change on a global scale through a process of policy transfer generated by international networks. The research identified how policy makers from both countries have become part of international youth justice networks and advocacy coalitions. These networks assist the development of youth justice systems in other countries that aim to meet international child justice standards and incorporate restorative justice principles. Within these coalitions, new ideas and adaptations of approaches continue to emerge, with attempts to improve practice around the core principles. New Zealand and South Africa have become important youth justice policy lenders to a number of other countries following the implementation of their youth justice systems. As a result, they have a responsibility to 
consider the impact of their policies and practices beyond their own borders and to demonstrate the best examples of policy and practice.

The research found that experiences of youth justice transformation in New Zealand and South Africa demonstrate ways to develop a youth justice approach that meets international standards for children's rights, utilises a holistic interpretation and application of restorative justice principles, and responds to the voices of community activists in policy formation. Nevertheless, the application of youth justice principles in both countries remains a work in progress. As identified, another generation of committed and passionate individuals and groups is needed to continue the implementation of the youth justice principles coupled with the political will to support this as part of the government's agenda. One area that could be enhanced in both countries is the involvement of children and young people in youth justice processes. Research on children and young people in the justice system indicates that when their needs are met and opportunities created for their future, they are less like to offend (Maxwell et al, 2004). This includes listening to their views on their experiences and their ideas on what would make a difference for them, as well as ensuring that these views are given weight in determining outcomes. This could include enabling young people to contribute to youth justice policy development. 


\section{Postscript}

In September 2012 I joined the youth justice policy team at New Zealand's Ministry of Social Development where I became part of an inter-agency ${ }^{373}$ initiative to review youth justice policy in New Zealand. This experience involved consulting with a number of practitioners, young people, community leaders and academic experts around the country with a focus on four key areas to generate discussion: prevention, diversion, FGCs and youth courts. ${ }^{374}$

Reminiscent of the voices from the community consultation from the 1980s, this recent round of consultation has once again urged government agencies to empower families and communities to enable them to take responsibility for decision-making which supports their children's development and reintegration. There was still strong support from the community for the principles and philosophy underpinning the youth justice system. However, there was also a call for improvements in practice and for providing opportunities to support children, young people and their families through difficult circumstances that have resulted in offending behaviour - consistent with the research findings.

Here is an opportunity for New Zealand to revive its youth justice system and to live up to its potential. Given New Zealand's trailblazing history in this area, should it be successful in enhancing its practice, it may provide renewed encouragement to other countries, including South Africa, through further policy transfer. Perhaps it is also an opportunity for New Zealand to learn lessons from South Africa's experience of youth justice transformation, particularly with regard to its approach to international standards for children's rights and its more explicit consideration for and reference to restorative justice principles.

\footnotetext{
${ }^{373}$ Government agencies involved include the Ministry of Social Development, the Ministry of Justice, Police, the Ministry of Health, the Ministry of Education and the Department of Māori Affairs (Te Puni Kokiri). ${ }^{374}$ Associate Minister for Justice and Social Development, Honourable Chester Burrows, who has taken a particular interest in youth justice in New Zealand, launched the initiative.
} 


\section{Appendix 1}

Dear

\section{REQUEST FOR AN INTERVIEW ON THE PROCESS OF YOUTH JUSTICE TRANSFORMATION}

I am a PhD student with the School of Government at Victoria University in Wellington. The topic of my thesis is a comparative analysis of youth justice transformation between South Africa and New Zealand. I have obtained Victoria University ethics approval for this research.

This research aims to explain the impact of significant role players in shaping the process of youth justice transformation both in South Africa and New Zealand with an emphasis on the Child, Young Persons and their Families Act of 1989 in New Zealand and the Child Justice Bill of 2002 in South Africa $^{375}$. In order to capture this information I wish to conduct in-depth interviews with key people who played a significant role in conceiving, designing and promoting the new approach to youth justice.

The focus of these in-depth interviews will be on identifying the values and principles underlying the process of youth justice transformation in both countries, and the inspiration for key role players in advancing these values and principles in policy and legislation. They will include policy and law makers; academics; those involved youth justice in both government and non-government sectors; key members of parliament tasked with promoting laws pertaining to youth justice; and members of national committees reporting to the United Nations Committee on the Rights of the Child.

I would like to invite you to participate in one of these in-depth interviews. Where possible, the interviews will be held face to face, but if not, we could talk by telephone. The interview should last approximately $1-1 \frac{1}{2}$ hours. It will be tape recorded, and you will be given the opportunity to check the information for accuracy prior to analysis.

Information from the in-depth interviews will be used as part of the comparative analysis which explores the rationale and notable influences driving youth justice transformation both in South Africa and New Zealand. Unless you give consent to have your name used, you will not be identified.

The content of the interviews will be kept in a confidential and safe manner in either a locked file or, if electronic, in a password protected file and will only be able to be accessed by the researcher and

\footnotetext{
${ }^{375}$ At the time participants were initially invited to participate the Child Justice Act of 2008 had not come into law. Invitations made after the legislation passed referred to it as the Child Justice Act of 2008.
} 
my supervisors, Dr Gabrielle Maxwell and Dr Karen Baehler from the School of Government at Victoria University in Wellington.

The thesis will be submitted to the School of Government for marking and deposited at the University Library. It is likely that articles will be submitted for publication in scholarly journals. The content of the interviews will be destroyed two years following the submission of the research.

Should you have any further questions regarding the research, please do not hesitate to contact me at

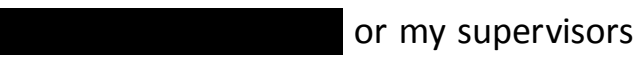

Thank you.

Sincerely yours

Ashley Shearar 


\section{Appendix 2}

\section{Key questions to be explored during the interviews:}

1- What was your role around the time youth justice policy and legislation was being developed/came into effect?

2- What key concepts did you consider important to include in the process of youth justice transformation?

3- What were your main influences in determining what was important to include in the process of youth justice transformation?

4- What do you consider was your main contribution to the development/promotion/implementation of new youth justice policy?

5- How were you able to make this contribution?

6- How did you see the main concepts you believed important to include in the process of youth justice transformation manifested in youth justice policy and legislation?

7- In what ways did you see those concepts transform into practical reality?

8- What do you consider the most effective outcome of youth justice transformation policy and legislation?

9- What do you consider the main challenges to the youth justice policy and practice?

10- How do you think these challenges can best be managed?

11- Anything to add?

Thank you. 


\section{$\underline{\text { Appendix } 3}$}

\section{VICTORIA UNIVERSITY OF WELLINGTON \\ Te Whare Wananga o te Upoko o te Ika a Maui

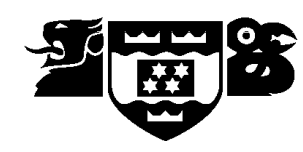

CONSENT TO PARTICIPATE IN RESEARCH

Title of Project: A Comparative Analysis of Youth Justice Transformation in South Africa and New Zealand

I have been given and understood an explanation of the research project. I have been given an opportunity to ask questions and had them answered to my satisfaction. I understand that I may withdraw myself (or any information I have provided) from this project before March 2011 without having to give reasons and without penalty of any sort.

I understand that any information I provide will be kept confidential to the researcher and the supervisors.

$\square$ I agree to take part in this research.

I consent to information or opinions which I have given to be attributed to me in any reports on this research.

$\square$ I would like the tape recordings of my interview returned to me at the conclusion of the project 
$\square$ I wish to have an opportunity to check the transcripts of the interview before publication

$\square$ I understand that the data I provide will not be used for any other purpose of released to others without my written consent.

$\square$ I would like to receive a summary of the results when it is completed.

Signed:

Name of Participant:

Date: 


\section{Appendix 4}

\section{Table identifying similarities in the key concepts underpinning the CYPF Act and the CJA}

\begin{tabular}{|c|c|}
\hline New Zealand & South Africa \\
\hline $\begin{array}{l}\text { Development } \\
\text { - Consideration should be given to the wishes of the child or young person, so } \\
\text { far as those wishes can reasonably be ascertained, and that those wishes } \\
\text { should be given weight as is appropriate in the circumstances, having regard } \\
\text { to the age, maturity, and culture of the child or young person (s5(d)) } \\
\text { - A child or young person's age is a mitigating factor in determining - } \\
\text { i. } \quad \text { whether or not to impose sanctions in respect of offending by a } \\
\text { child or young person; and } \\
\text { ii. the nature of any such sanctions (s208(e)) } \\
\text { - The vulnerability of children and young persons entitles a child or young } \\
\text { person to special protection during any investigation relating to the } \\
\text { commission or possible commission of the offence by that child or young } \\
\text { person (s208(h)) } \\
\text { Any sanction imposed on a child or young person who commits an offence } \\
\text { should - } \\
\text { i. take the form most likely to maintain and promote the development } \\
\quad \text { of the child or young person within his or her family, whānau, } \\
\text { hapu, and family group; and } \\
\text { ii. take the least restrictive form that is appropriate in the } \\
\text { circumstances; (s208(f)) }\end{array}$ & $\begin{array}{l}\text { Development } \\
\text { - Fostering children's sense of dignity and worth (s2(b)(i)) } \\
\text { A child must not be treated more severely than an adult would have been } \\
\text { treated in the same circumstances (s3(b)) } \\
\text { Every child should, as far as possible, be given an opportunity to participate } \\
\text { in any proceedings, particularly in terms of this Act, where decisions } \\
\text { affecting him or her might be taken (s3(c)) } \\
\text { - Every child should be addressed in a manner appropriate to his or her age } \\
\text { and intellectual development and should be spoken to and be allowed to } \\
\text { speak in his/her language, through an interpreter if necessary. (s3(d)) } \\
\text { - Every child should be treated in a manner which takes into account his or } \\
\text { her cultural values and beliefs (s3(e)) } \\
\text { A child lacking in family support or educational or employment } \\
\text { opportunities must have equal access to available services and every effort } \\
\text { should be made to ensure that children receive similar treatment when } \\
\text { having committed similar offences (s3(h)) } \\
\text { Diversion } \\
\text { Prevent children from being exposed to the adverse effects of the formal } \\
\text { criminal justice system by using, where appropriate, processes, procedures, } \\
\text { mechanisms, services or options more suitable to the needs of children and } \\
\text { in accordance with the Constitution, including the use of diversion (s2(d)) }\end{array}$ \\
\hline
\end{tabular}




\section{Preventing further offending}

- Any measures for dealing with offending by a child or young person should so far as is practicable to do so address the causes underlying the child's or young person's offending (s208(f))

\section{$\underline{\text { Restorative justice principles }}$}

- In the determination of measures for dealing with offending by children or young persons, consideration should be given to the interests or views of any victims of the offending (for example, by encouraging the victims to participate in the processes under this Part dealing with offending $(\mathrm{s} 208(\mathrm{~g})$ )

- Any measures should have proper regard for the interests of any victims of the offending and the impact of the offending on them

\section{Involving families and communities}

- Any measures for dealing with offending by children or young persons should be designed -

i. to strengthen the family, whānau, hapu, iwi and family group of the child or young person concerned; and

ii. to foster the ability of families, whānau, hapu, iwi and family groups to develop their own means of dealing with offending by their children and young persons (s208c)

\section{Timeliness}

- Decisions affecting a child or young person should, wherever practicable, be made and implemented within a time-frame appropriate to the child's or young person's sense of time (s5(f))

\section{Care and protection}

- Criminal proceedings should not be instituted against a child or young person solely in order to provide any assistance or services needed to advance the welfare of the child or young person, or his or her family,

\section{Preventing further offending}

- Provide for the special treatment of children in a child justice system designed to break the cycle of crime, which will contribute to safer communities and encourage these children to become law-abiding and productive adults (s2(c))

\section{Restorative justice principles}

- Promote the spirit of ubuntu in the child justice system (s2(b))

- Reinforcing children's respect for human rights and the fundamental freedoms of others by holding children accountable for their actions and safe-guarding the interests of victims and the community (s2(b)(ii))

- Supporting reconciliation by means of a restorative justice response (s2(b)(iii))

\section{Involving families and communities}

- Involving parents, families, victims and, where appropriate, other members of the community affected by the crime in procedures in terms of this Act in order to encourage the reintegration of children (s2b(iv))

- Parents, appropriate adults and guardians should be able to assist children in proceedings in terms of this Act and, wherever possible, participate in decisions affecting them $(\mathrm{s} 3(\mathrm{~g}))$

\section{Timeliness}

- All procedures in terms of this Act should be conducted and completed without unreasonable delay $(\mathrm{s} 3(\mathrm{~g}))$

\section{Care and protection}

- If it appears to the inquiry magistrate during the course of a preliminary inquiry that:

a) a child is in need of care and protection referred to in Section 150 


\begin{tabular}{|c|c|}
\hline whānau or family group (s208(c)) & $\begin{array}{l}\text { (1) or (2) of the Children's Act, and it is desirable to deal with the } \\
\text { child in terms of sections } 155 \text { and } 156 \text { of the Act: or } \\
\text { b) the child does not live at his or her family home or in appropriate } \\
\text { alternative care; or } \\
\text { c) the child is alleged to have committed a minor offence or offences } \\
\text { aimed at meeting the child's basic need for food and warmth } \\
\text { the inquiry magistrate may stop the proceedings and order that the child be brought } \\
\text { before a children's court referred to in section } 42 \text { of that Act and that the child be } \\
\text { dealt with under the said sections } 155 \text { and } 156 .(\mathrm{s} 50)\end{array}$ \\
\hline
\end{tabular}




\section{Bibliography}

Akester, K. (2003), 'Restorative justice, victims' rights and the future' in Articles and views on RJ - Restorative justice consortium.

An-Na'im, A. (1994), "Cultural transformation and the normative consensus on the best interests of the child" in Alston, P. (Ed.) The best interests of the child-Reconciling culture and human rights. (Unicef-Clarendon Press: Oxford)

Ashford, D.E. (1992), History and context in comparative public policy. (University of Pittsburgh Press: Pittsburgh)

Atmore, E. (1992), Apartheid and South Africa's children. (Clearing House: Washington)

Austin, J.E (2006), 'The three avenues for social entrepreneurship research' in Mair, J., Robinson; J. and Hockerts, K. (Eds.) Social entrepreneurs. (Palgrave McMillan: Hampshire)

Badenhorst, C. (2011), 'Overview of the implementation of the Child Justice Act, 2008 (Act 75 of 2008) 'Good intentions, questionable outcomes'. (Open Society for South Africa: Cape Town)

Barry, M. (2006), Youth offending in transition-The search for recognition. (Routledge: London and New York)

Bartol, C.R. and Bartol, A.M. (1989), Juvenile delinquency-A systems approach (Prentice Hall: New Jersey)

Bawa, U. (date unknown), 'Organised violence in apartheid South Africa: Children as victims and perpetrators'.

Bazemore, G.and Bell, D. (2004), 'What is the appropriate relationship between restorative justice and treatment?' in Zehr, H. And Toews, B. (Eds.) Critical issues in restorative justice. (Monsey, New York Criminal Justice Press)

Beck, R. B. (2000). The history of South Africa. (Greenwood Publishing Group)

Becroft, A. (2003), 'Past lessons and future challenges-A paper for the Australian Institute of Criminology/NSW Department of Juvenile Justice Juvenile Justice Conference, Sydney 1-2 December 2003.

Becroft, A. (2009), 'Are there lessons to be learned from the youth justice system?' in Maxwell, G. (Ed.) Addressing the causes of offending. What is the evidence? (Institute of Policy Studies, School of Government: Victoria University, Wellington)

Bornstein, D. (2007), Ten questions with David Bornstein, Available at http://blog.guykawasaki.com/2007/09/social-entrepre.html\#ixzz1fW1lmzBI 
Bornstein (2002), Private correspondence in Davis, S. (2002) Social entrepreneurship: Towards an entrepreneurial culture for social and economic development. Prepared for the Youth Employment Summit, September 7 - 11, 2002.

Borschee, J. (2006), 'Social Entrepreneurship: The promise and the perils' in Nicholls (Ed.) Social Entrepreneurship: New Models of Sustainable Social Change. (Oxford University Press: Oxford)

Boyack, J., Bowen, H. and Marshall, C. (2004), 'How does restorative justice ensure good practice?' in Zehr, H. and Toews, B. Critical issues in restorative justice. (Monsey, New York: Criminal Justice Press)

Braithwaite, J. (1989), Crime, shame and reintegration (Cambridge University Press, Cambridge)

Braithwaite, J. (2000), Standards for restorative justice - United Nations Crime Congress: Ancillary meeting: Vienna, Australia.

Brookes, D.R. (2000), Evaluating restorative justice programmes - United Nations Crime Congress: Ancillary meeting: Vienna, Australia.

Bronfenbrenner, U. (1979), The ecology of human development - Experiments by nature and design. (Harvard University Press: Cambridge, Massachusetts and London, England)

Brown, M. (1992), 'Juvenile justice in New Zealand'. National Conference on Juvenile Justice 22-24 September 1992.

Cairns, E. (1996), Children and political violence (Blackwell Publishers: Oxford)

Campaign letter written by Mary Burton, the National President of the Black Sash (Black Sash archives)

Campbell, T.D. (1992), 'The rights of the minor: as person, as child, as juvenile as future adult' in Alston, P., Parker, S. and Seymore, J. (eds.) Children, rights and the law (Clarendon Press: Oxford)

Carrim, Y. Member of Parliament in the South African Parliament - Brief Political CV.

Catalano, R.F. and Hawkins, D.J. (1996), 'The social development model-A theory of antisocial behaviour' in Hawkins, J.D. (Eds.) Delinquency and crime-Current theories (Cambridge University Press. USA)

Cheyne. C, O'Brien. M and Belgrave, M. (2000), Social policy in Aotearoa-New Zealand-A critical introduction. (Oxford University Press: Australia and New Zealand)

Child Justice Alliance (2010), Child Justice Act monitoring implementation tool. (Community Law Centre: University of the Western Cape) 
Cho, A.H. (2006), 'Politics, values and social entrepreneurship: A critical appraisal' in Mair, J., Robinson; J. and Hockerts, K. Social entrepreneurs. (Palgrave McMillan: Hampshire)

Cipriani, D. (2009), Children's rights and the minimum age of criminal responsibility: A global perspective. (Ashgate Publishing: Burlington)

Cleave, P. (1989), The sovereignty game: Power, knowledge and reading the Treaty (Institute of Policy Studies-Victoria University Wellington)

Conger, R.D. and R.L. Simons (2006), 'Life course contingencies in the development of adolescent anti-social behaviour: A matching law approach' in Thornberry, P.T.

Developmental theories of crime and delinquency. (Transactional Publishers: USA)

Consedine, R. And Consedine, J. (2001), Healing our history -The challenge of the Treaty of Waitangi. (Penguin Group NZ: Auckland)

Cunneen, C. (2004), 'What are the implications of restorative justice's indigenous traditions?' in Zehr, H. and Toews, B. (Eds.) Critical issues in restorative justice. (Monsey New York, Criminal Justice Press)

Cunneen, C. (2007), 'Reviving restorative justice traditions?' in Johnston, G. and Van Ness, D. (Eds.) Restorative justice handbook. (Willan Publishing: Cullompton)

Cunneen, C. and White, R. (2002), Juvenile justice: Youth and crime in Australia.

Melbourne: (Oxford University Press: Melbourne)

Dalley, B. (1998), Child welfare in $20^{\text {th }}$ century New Zealand (Auckland University Press)

Davis, (2002), Social entrepreneurship: Towards an entrepreneurial culture for social and economic development. Prepared by request for the Youth Employment Summit, September 7-11, 2002

Dawes, A. (1990), 'The effects of political violence on children: A consideration of South African and related studies' in International journal of psychology 25 North Holland

Defence for Children International (2005), 'No kids behind bars campaign', Defence for children in conflict with the law to combat state violence - contribution by to the UN Secretary General Study on Violence against Children July 2005.

Defence for Children International (2011), Deprivation of children's liberty as a last resort. Kampala Conference, 7-8 November 2011. Available from the World Wide Web at: http://kampalaconference.info/index.php?option $=$ com_contentand view $=$ articleandid $=49 \mathrm{andIt}$ emid $=37$

Department of Social Welfare (1984), Review of Children and Young Persons Legislation Public Discussion Paper (Wellington: Department of Social Welfare)

Department of Social Welfare (1987), Review of the Children and Young Person's Bill Report of the Working Party on the Children and Young Person's Bill (Wellington: Department of Social Welfare) 
Detrick, S. (1992), The United Nations Convention on the Rights of the Child-A guide to the 'Travaux Preparatoire'. (Martinus Nijhoff Publishers: Dordrecht, Boston, London)

Dolowitz, D.P. and Marsh, D. (2000), 'Learning from abroad: The role of policy transfer in contemporary policy-making'. Governance: An international journal of policy and administration, Vol 13, No 1, January 2000; pp5-24. (Blackwell Publishers)

Doolan, M. (1988), From welfare to justice: Towards new social work practice with young offenders. An overseas study tour report. (New Zealand Department of Social Welfare: Wellington)

Dowdall, T. (1994), 'The right of a child to a secure family life' Proceedings of the International Seminar of the Community Law Centre at the University of the Western Cape 25-27 March 1994.

Dowding, K. (2009) in McLean, I. and McMillan, A. (Eds.) The Concise Oxford dictionary of politics. (Oxford University Press: Oxford)

Drayton, W. (2006), 'The citizen sector transformed' in Nicholls, A. Social entrepreneurship: New models of sustainable social change. (Oxford University Press: Oxford)

Dumortier, E. (2000), Neglecting due process for minors: A possible dark side of the restorative justice implementation. (Free University of Brussels: Brussels)

Durie, M.H. (1989), 'The Treaty of Waitangi: perspectives on social policy' in Waitangi Māori perspectives on the Treaty of Waitangi. (Oxford University Press: Auckland).

Elliott, D.S. and Menard, S. (1996), 'Delinquent friends and delinquent behaviour' in Hawkins, J.D. (Ed.) Delinquency and crime - Current theories. (Cambridge University Press: USA)

Farrington, D.P. (1996) 'The explanation and prevention of youthful offending' in Hawkins, J.D. (Ed.) Delinquency and crime - Current theories. (Cambridge University Press: USA)

Free the Children Alliance (1988), The Children's Commission - Apartheid on Trial. Conference held at the Wits Great Hall in Johannesburg, April 1988.

Free the Children Alliance (undated), 'Letter to interested agencies following their initial meeting held on 16 February 1987' (Black Sash archives - Manuscripts and Archives: University of Cape Town)

Gallinetti, J. (2009), Getting to know the Child Justice Act. (Child Justice Alliance, Community Law Centre: University of the Western Cape)

Garbarino, J. (1982), Children and families in the social environment. (Aldine Publishing Company: New York) 
Gabarino, J., Dubrow, N., Kostelny, K. and Pardo, C. (1992), Children in danger: Coping with the consequences of community violence. (Jossey-Bass Publishers: San Fransisco)

Gillham, B. (2000), Case study research methods. (Continuum: London, New York)

Grace, P., Irihapeti, R. and Dennis, J. (2001), The silent migration-Ngati Poneke Young Māori Club 1937-1948. (Huia Publishers:Wellington)

Gray, D.E. (2004), Doing research in the real world. (Sage Publications: London)

Gray, M. and Lombard, A. (2008) 'The post - 1994 transformation of social work in South Africa', International Journal of Social Welfare (Special issue guest edited by Mel Gray), 17(1) (2008)

Greeff, M. (2002), 'Information collection: Interviewing' in De Vos, A.S. (eds.) Research at grassroots-For the social sciences and human service professions (2nd Ed.). (Van Schaik Publishers: Pretoria)

Hakiaka, M. (2004) 'What is the state's role in indigenous justice processes?' in Zehr, H. and Toews, B. (Eds.) Critical issues in restorative justice. (Monsey New York, Criminal Justice Press)

Henning, E. (2004), Finding your way in qualitative research. (Van Schaik Publishers, Pretoria)

Hickey, M. (2007), 'Negotiating history: Crown apologies in historical Treaty of Waitan gi settlements' in Maxwell, G. and Liu, J. (Eds.) Restorative justice and practices in New Zealand. (Institute of Policy Studies: Wellington)

Human Rights Watch (1994), Prison conditions in South Africa. (Human Rights Watch: New York)

International Defence and Aid Fund (1988), Apartheid's violence against children - Fact paper No 15

In Re Gault, 387 U.S. 1[1967] In Re Gault et.al. Appeal from the Supreme Court of Arizona, No. 116 Argued December 6, 1966, Decided May 15, 1967)

Inter-ministerial Committee for Youth at Risk (1998), Piloting change for youth at risk (IMC: South Africa)

International Juvenile Justice Observatory (2012), 'Criminality or social exclusion? Justice for children in a divided world'. The fifth biennial conference of the international juvenile justice observatory. 6 - 7 November 2012, London.

Jackson, M. (1987), Māori and the criminal justice system-A new perspective: He Whaipaanga Hou (New Zealand Ministry of Justice: Wellington) 
Jensen, E. and Jepsen, J. (2006), Juvenile law violators, Human rights and the development of the juvenile justice system. (Hart Publishing: Oxford)

Johnstone, G. (2004), 'How, and in what terms should restorative justice be conceived?' in Zehr, H. and Toews, B. (eds.) Critical issues in restorative justice. (Monsey, New York Criminal Justice Press)

Julich, S. (2003) Critical issues in restorative justice: Advancing the agenda in Aotearoa. (Massey University, Auckland)

Juvenile Justice Drafting Consultancy (1994), Juvenile justice for South Africa: Proposals for policy and legislative change. (Cape Town: Allies Printers)

Ka'ai, T. (2004), 'Te Mana o te Tangata Whenua-Indigenous assertions of sovereignty'. In $K i$ te whaiao: An introduction to Māori culture and society. (Pearson Education, Auckland, New Zealand)

Keenan, D. (2005), 'Te Whiti-o-Rongomai III' in The dictionary of online biography. Available from the World Wide Web at http://www.teara.govt.nz/en/biographies/2t34/1

Kinnes, I. (2000), From urban gangs to criminal empires - The changing face of gangs in the Western Cape. (Institute of Security Studies, Monograph Series No. 48, June 2000, Pretoria)

Klinger, E. (2006) 'Diffusion and adoption of innovations: A development perspective' in Bertucci, G. (Ed) Innovations in governance and public administration: Replicating what works. (Department of Economic and Social Affairs: United Nations)

Letter between Black Sash members, Jenny de Tolly and Isobel Douglas-Jone dated 1 March 1987 (Black Sash archives: University of Cape Town)

Leventhal, J. (1997). 'The prevention of child abuse and neglect: Pipe dreams or possibilities?' in Clinical child psychology and psychiatry. Vol. 2; p 489-500.

Leviner, N., Crutchfield, L.R. \& Wells, D. (2006), 'Understanding the impact of social entrepreneurs: Ashoka's answer to the challenge of measuring effectiveness' in R. MosherWilliams (ed.), Research on Social Entrepreneurship: Understanding and Contributing to an Emerging Field, (ARNOVA Occasional Paper Series, vol. 1, no. 3, pp. 89-104).

Liu, J. (2007), 'Social and historical contexts for restorative and retributive justice: Te ao pō - Te ao mārama (Worlds of dark and light)' in Maxwell, G. and Liu, J. (eds.) Restorative justice and practices in New Zealand: Towards a restorative society. (Institute of Policy Studies: Wellington)

Lofton, B.P. (2004), 'Does restorative justice challenge systemic injustices?' in Zehr, H. and Toews, B. Critical issues in restorative justice. (Monsey, New York, Criminal Justice Press)

Lundberg, M. \& Wuermli, A. (2012), Children and youth in crisis: Protecting and promoting human development during economic shocks. (World Bank Publications) 
Mabandla, B. (2008), Introductory speech by Ms Brigitte Mabandla, MP, Minister for Justice and Constitutional Development, in second reading debate on the Child Justice Bill, on Wednesday, 25 June 2008, in the National Assembly, Parliament

Maepa, T. (1998), 'The Truth and Reconciliation Commission as a model of restorative justice- Restorative justice in practice' in Beyond Retribution-Prospects for Restorative Justice in South Africa. (Volume 1 of the Truth and Reconciliation Commission of South Africa Report)

Mair and Noboa (2006), 'Social entrepreneurship: How intentions to create a social venture are formed' in Mair, J., Robinson; J. and Hockerts, K. Social entrepreneurs. (Palgrave McMillan: Hampshire)

Mandela, N. (1994), State of the Nation Address, President Mr NR Mandela-Houses of Parliament, May 24, 1994

Maxwell, G., Lo, T. and Wong, D.S.W. (2005) 'Introduction: The changing themes in youth justice' in Lo, T. and Wong, S.W. and Maxwell, G., (eds.) Alternatives to prosecution: Rehabilitative and restorative models of youth justice. (Singapore: Marshall Cavendish)

Maxwell, G., Kingi, V., Robertson, J., Morris, A. and Cunningham, C. (2004), Achieving effective outcomes in youth justice. (New Zealand: Ministry of Justice)

Maxwell, G. and Morris, A. (1993) Families, victims and culture: Youth justice in New Zealand. (New Zealand: Ministry of Social Development)

Maxwell, G. and Morris, A. (2001), 'Family group conferencing and reoffending' in Morris, A. and Maxwell, G. (eds.) Restorative justice for juveniles - Conferencing, Mediation and Circles. (Hart Publishing: Portland, Oregon)

Maxwell, G. and Morris, A. (2004), 'What is the place of shame in restorative justice?' in Zehr, H. and Toews, B. (eds.) Critical issues in restorative justice. (Monsey, New York: Criminal Justice Press)

McCold, P. (2004), 'What is the role of community in restorative justice theory and practice?' in $\mathrm{H}$. Zehr and B. Toews (eds.), Critical issues in restorative justice (Monsey, New York Criminal Justice Press)

McCurdie, J. (1989), Their only right a name: Children under the state of emergency in South Africa, report prepared on behalf of the Free the Children Alliance for the International Congress on Working for Children's Rights held in Finland from 16-18 June 1989 (Black Sash archives: University of Cape Town)

McLachlan, F. (1985), 'Children in prison: South Africa' in Centre Against Apartheid, Notes and Documents No. 2/85. (United Nations: New York)

Meintjies, H., Hall, K., Marera, D.H. and Boulle, A. (2006), Child-headed households in South Africa: A statistical brief. (Children's Institute: University of Cape Town) 
Metge, J. (1986), In and out of touch-Whakamaa in cross-cultural contexts. (Victoria University Press: Wellington)

Metge, J. (1995), New growth from old-The whānau in the modern world. (Victoria University Press: Wellington)

Metge, J. (2001) Korero tahi - Talking together. (Auckland University Press: Auckland) Mikaere, A (2008), Te Tiriti and the Treaty: Seeking to reconcile the irreconcilable in the name of truth. (unpublished report)

Ministry of Justice (2012), Trends for children and youth in the New Zealand justice system. (Ministry of Justice: New Zealand)

Mintrom, M. (1997), 'Policy entrepreneurs and the diffusion of innovation', in American journal of Political Science. Vol. 41, No 3 (July 1997) pp. 738 - 770. (Midwest Political Science Association)

Moffitt, T.E. (2006), 'Adolescence-limited and life course persistent offending: A complementary pair of developmental theories' in Thornberry, P.T. (ed.) Developmental Theories of Crime and Delinquency. (Transactional Publishers: USA)

Morris, A. and Young, W. (1987), 'Juvenile justice in New Zealand: Policy and practice' in Study series 1, Institute of Criminology. (Victoria University Press: Wellington)

Morris, A. and Maxwell, G. (2001), Restorative justice for juveniles: Conferencing, mediation and circles. (Oxford: Portland-Oregon)

Morris, A. (2004), 'Youth Justice in New Zealand', Youth crime and youth justice: Comparative and cross-national perspectives Crime and Justice-A Review of Research Vol. 31

Mosher-Williams, R. (2006), Research on social entrepreneurship: Understanding and contributing to an emerging field. Arnova Occasional Paper Series: Vol. 1(3) (Washington D.C.)

Mulgan, G. (2006), 'Cultivating the other invisible hand of social entrepreneurship: Comparative advantage, public policy, and future research priorities' in Nicholls, A. (Ed.) Social entrepreneurship: New models of sustainable social change. (Oxford University Press: Oxford)

Mulgan, R. (1989), Māori, Pākehā and Democracy. (Oxford University Press: Melbourne) Mulley, C. (2009), The woman who saved children-A biography of Eglantyne Jebb, founder of Save the Children. (One World Publications: Oxford, England)

Muncie, J. (1999), Youth and crime-A critical introduction. (Sage Publications, London, Thousand Oaks) 
Muntingh, L. (1998, 2000), The effectiveness of diversion - a longitudinal evaluation of cases. (Cape Town: South Africa National Institute for Crime Prevention and Reintegration of Offenders)

New Zealand Department of Social Welfare (1983), Maatua Whangai Policy Objectives

New Zealand Ministerial Advisory Committee on a Māori Perspective for the Department of Social Welfare (1988), Puao-te-ata-tu (Day break): the report of the Ministerial Advisory Committee on a Māori Perspective for the Department of Social Welfare (Wellington: The Department of Social Welfare)

Nicholls, A. (2006), 'Introduction' in Nicholls, A. (Ed.) Social entrepreneurship: New models of sustainable social change. (Oxford University Press: Oxford)

Nixon, M. (1987), 'Appendix Four' in New Zealand Department of Social Welfare, Review of Children and Young Persons Bill (Report of the Working Party on the Children and Young Person's Bill)

Orange, C. (1987), The Treaty of Waitangi. (Allen and Unwin: Wellington)

Pakura, S. (2004), The Family Group Conference 14-year journey: Celebrating the successes, learning the lessons, embracing the challenges Paper presented at the American Humane Association's Family Group Decision-making Conference and Skills-Building Institute, June 6-9, 2004, in Harrisburg, Pennsylvania, USA. Available at:

http://www.familypower.org/library/au05_pakura.html

Parliament of the Republic of South Africa (2011), Promoting children's rights in South Africa: A handbook for members of Parliament, (Parliament of the Republic of South Africa)

Perrini, F. and Vurro, C. (2006), 'Social entrepreneurship: How intentions to create a social venture are formed' in Mair, J., Robinson; J. and Hockerts, K. (eds.) Social entrepreneurs. (Palgrave McMillan: Hampshire)

Phillips, E. (1945), Juvenile Delinquency in New Zealand, (Whitcombe and Tombs: New Zealand)

Pinnock, D. (1997), Gangs, rituals and rites of passage. (African Sun Press: Cape Town)

Pinnock, D. Skelton, A. and Shapiro, R. (1994), New juvenile justice legislation for South Africa-Giving children a chance. Occasional Paper Series 3-94 (Institute of Criminology: University of Cape Town)

Pinnock, D. (2011), 'Child Justice Act undercut from within' in the Mail and Guardian dated 30 September 2011. Available at http://mg.co.za/article/2011-09-30-child-justice-actundercut-from-within

Quince, K. (2007), 'Māori and the criminal justice system in New Zealand' in Tolmie, J. and Brookbanks, W. (eds.) The New Zealand criminal justice system, pp. 1-26 (Auckland, LexisNexis) 
Renouf, J., A. Lagzdins and Angus, J. (1989), Children, Young Persons and their Families Act 1989 - The process of social policy development. (New Zealand Department of Social Welfare)

Report on the "Children's Commission-Apartheid on Trial" (undated) Letter between Black Sash members, Jenny de Tolly and Isobel Douglas-Jones dated 1 March 1987 following Adriaan Vlok's response dated 23 January 1987 (Black Sash archives: University of Cape Town).

Roberts, D. and Woods, C. (2005), 'Changing the world on a shoestring: The concept of social entrepreneurship' in University of Auckland Business Review, ISSN 1174-9946, 45-51.

Rose, R. (2005), Learning from comparative public policy - A practice guide. (Routledge: London and New York)

Saayman vs. the State (CAandR 82/2007 [2007] ZAECHC 109 [7 December 2007]

Sachs, A. (1994) The right of a child to a secure family life-Proceedings of the International Seminar of the Community Law Centre at the University of the Western Cape 25-27 March 1994

Sampson, R.J. and Laub, J.H. (2006), 'A life-course theory of cumulative disadvantage and the stability of delinquency' in Thornberry, P.T. (ed.) Developmental theories of crime and delinquency. (Transactional Publishers: USA)

Sawin, J.L. and Zehr, H. (2007), 'The ideas of engagement and empowerment' in Johnstone, G. and Van Ness, D. (Eds.) Handbook of restorative justice. (Willan Publishing: Devon)

Scholte, J.A. (1993), International relations of social change. (Open University Press: Buckingham)

Shearar, J.B. (2011) Against the world: South Africa and human rights at the United Nations 1945-1961, (Unisa Press: Pretoria)

Simon, H. (1972), 'Theories of bounded rationality' in C. B. McGuire and R. Radner (eds.), Decision and Organization. (Amsterdam: North-Holland Publishing Company)

Skelton, A. (1994), 'Developing a comprehensive juvenile justice system in South Africa' in Glanz, L (ed.) Preventing juvenile offending in South Africa, (Human Science Research Council: Pretoria)

Skelton, A. (2005), The influence of the theory and practice of restorative justice in South Africa with special reference to child justice. (LLD: University of Pretoria: Pretoria)

Skelton, A. (2007), 'Regional reviews: Africa' in Johnstone, G and Van Ness, D.W. (eds.) Handbook of restorative justice. (Willan Publishing: Devon) 
Skelton, A. and Badenhorst, C. (2011), The criminal capacity of children in South AfricaInternational developments and consideration for a review (The Child Justice Alliance: University of the Western Cape)

Skelton, A. and Frank, C. (2001), 'Conferencing in South Africa: Returning to our future' in Morris, A. and Maxwell, G. (Eds.) Restorative justice for juveniles - Conferencing, mediation and circles. (Hart Publishing: Oxford - Portland, Oregon)

Skelton, A. and Frank, C. (2004), 'Does restorative justice address human rights and due process issues?' in Zehr, H. and Toews, B. (eds.) Critical issues in restorative justice. (Monsey, New York Criminal Justice Press)

Skelton, A. and Tshehla, B. (2008), Child justice in South Africa. Monograph 150. (Institute for Security Studies: Pretoria)

Skoll, J. (2006), 'Preface' in Nicholls, A. (ed.) Social entrepreneurship: New models of sustainable social change. (Oxford University Press: Oxford)

Sloth-Nielsen, J. (2001) The role of international law in South Africa's juvenile justice reform process (Doctoral thesis; University of the Western Cape)

Sorrenson,M.P.K. (1989:160), 'Towards a radical interpretation of NZ history' in Waitangi Māori Perspectives on the Treaty of Waitangi. (Oxford University Press: Auckland)

South African Department of Justice and Constitutional Development (2002), Child Justice Bill Budget and Implementation Plan. (Department of Justice and Constitutional Development: Intersectoral Committee for Child Justice)

South African Department of Justice and Constitutional Development (2011), 'Annual report on the implementation of the Child Justice Act, 2008 (Act 75 of 2008)'

South African Law Reform Commission (1999), Juvenile Justice Discussion Paper 79

South African Law Reform Commission Juvenile Justice Report-Project 106 - July 2000

Stone, D. (2001), Learning lessons, policy transfer and the international diffusion of policy ideas. Centre for the Study of Globalisation and Regionalisation (CSGR) Working Paper No. 69/01. (University of Warwick, Coventry: UK)

Tauri, J. (1998), 'Family group conferencing: A case study of the indigenisation of New Zealand's justice system' in Current issues in criminal justice. Vol. 10, No.2, November (University of Sydney: Sydney)

Thomas, N. (2006), Key concepts of Tikanga Māori (Māori Custom Law) in Tai Tokerau past and present. (Auckland University Press: Auckland)

Thornberry, T.P. (1996), 'Empirical support for interactional theory' in Hawkins J.D. (ed.) Delinquency and crime current theories. (Cambridge University Press: USA). 
Toews, B. and Katounas, J. (2004), 'Have offenders needs and perspectives been adequately incorporated into RJ?' in Zehr, H. And Toews, B. (eds.) Critical issues in restorative justice. (Monsey, New York Criminal Justice Press)

Trasler, G. (1972), 'The context of social learning' in Mays, J.B (ed.) Juvenile delinquency, the family and the social Group (Longman: Bristol)

Turia, T. (2010), Speech: Taranaki restorative justice seminar. Available at http://www.voxy.co.nz/politics/speech-taranaki-restorative-justice-seminar-hon-tarianaturia/5/42808. (24 March 2010, Taranaki)

Umbreit, M.S. and Coates R.B. (2000), Multi-cultural implications of restorative justice: Potential pitfalls and dangers. (Centre for Restorative Justice and Peace-making, School of Social Work University of Minnesota St. Paul, Minnesota)

United Nations Committee on the Rights of the Child (2007), General Comment No.10 Children's rights in juvenile justice. $44^{\text {th }}$ Session, Geneva 15 January - 2 February 2007.

United Nations (1980), Sixth United Nations Congress on the Prevention of Crime and the Treatment of Offenders: Juvenile Justice: Before and after the onset of delinquency: Caracas, Venezuela, 25 August to 5 September 1980

United Nations (1985) Seventh United Nations Congress on the Prevention of Crime and the Treatment of Offenders: Youth, Crime and Justice: Milan, Italy, 26 August to 6 September 1985

United Nations (1990) Eighth United Nations Congress on the Prevention of Crime and the Treatment of Offenders: Prevention of delinquency, juvenile justice and protection of the young-Policy approaches and directions: Havana, Cuba 27 August to 7 September 1990

United Nations (2006), Cross-cutting issues in juvenile justice-Criminal justice assessment toolkit. (United Nations, New York)

UNICEF (1987) Children on the frontline: The impact of apartheid, destabilisation and warfare on children in Southern and South Africa.

UNICEF International Child Development Centre (1998), 'Juvenile justice' in Innocenti Digesti 3.

Van Bueren, G. (1995), The international law on the rights of the child. (Martinus Mijhoff Publishers: Dordrecht).

Van Ness , D., Morris, A. and Maxwell, G. (2001), 'Introducing restorative justice' in Morris, A. and Maxwell, G. (eds.) Restorative justice for juveniles - Conferencing, mediation and circles. (Hart Publishing: Oxford - Portland, Oregon) 
Vasil R, (1990), What do Māori want? New political perspectives. (Random Century: New Zealand)

Waitangi Tribunal Report (1998), 'The Whānau o Waiperera Report' in Wai 414 (GP Publications)

Walgrave, L. (2004), 'Has restorative justice appropriately responded to retribution theory and impulses?' in Zehr, H. and Toews, B. (eds.) Critical issues in restorative justice. (Monsey, New York: Criminal Justice Press)

Walgrave, L. (2003), 'Restorative justice for juveniles: just a technique or a fully-fledged alternative?' in Johnstone, G. (Ed.) Restorative Justice Reader. (Willan Publishing: Devon)

Walker, R. (1990), Kaiwhawha tonu matou-Struggle without end. (Penguin Books)

WARAG Report (1985). Report of the Women Against Racism Action Group. Wellington: Department of Social Welfare.

Warner-Roberts, A. (2004), 'Is restorative justice tied to specific models of practice?' in Zehr, H. and Toews, B. (eds.) Critical issues in restorative justice (Monsey, New York: Criminal Justice Press)

Warwick, D.P. (1973), Comparative research method. (Prentice-Hall International Inc.: London)

Watt, E. (2003), A History of youth justice in New Zealand. (New Zealand Ministry of Justice: Wellington)

Wonshé (2004), "How does the "who, what, where and when" affect the practice of restorative justice?' in Zehr, H. and Toews, B. (eds.) (2004) Critical issues in restorative justice. (Monsey, New York Criminal Justice Press)

Wood, C. (2003), Diversion in South Africa-An overview of policy and practice from 1990 2003. Occasional Paper 79 October 2003 (Institute of Security Studies: Pretoria)

Yin, R. (1984), Case study research: Design and methods. (Sage publications: London)

Young, R. (2006), 'For what it is worth: Social value and the future of social entrepreneurship' in Nicholls, A. (ed) Social entrepreneurship: New models of sustainable social change. (Oxford University Press: Oxford)

Zehr, H. (2002), The little book of restorative justice (Good Books; Intercourse, PA)

Zehr, H. (1990), Changing lenses: A new focus for crime and justice (Herald Press: Scottdale, Pennsylvania, Waterloo, Ontario)

Zehr, H. and Toews, B.(2004), 'Social justice' in Zehr, H. and Toews, B. (eds.) Critical issues in restorative justice (Monsey, New York Criminal Justice Press) 
Zehr, H. (2007), 'Restorative justice continuum' Tributary stream of a healing river. Available at: http://wn.com/restorative_justice_continuum_howard_zehr_phd_emu. (Heartspeak productions)

\section{Treaties}

Treaty of Waitangi (1840)

Universal Declaration of Human Rights (1948)

Declaration of Children's Rights (Declaration of Geneva) (1959)

Covenant on Civil and Political Rights (1966)

Standard Minimum Rules for the Treatment of Prisoners (1955)

United Nations Guidelines for the Prevention of Juvenile Delinquency (The Riyadh Guidelines) (1990)

Havana Rules for youngsters deprived of their liberty (1990)

United Nations Convention on the Rights of the Child (UNCRC)

United Nations Standard Minimum Rules for the Administration of Juvenile Justice (The Beijing Rules) (1985)

\section{Legislation}

New Zealand Children, Young Persons and their Families Act of 1989

New Zealand Children, Young Persons and their Families (Youth Courts Jurisdiction and Orders) Amendment Act of 2010

New Zealand Children and Young Persons Bill of 1984

New Zealand Children and Young Person's Act of 1974

New Zealand Children's Welfare Act of 1925

New Zealand Neglected and Criminal Children's Act 1867

South African Child Care Act of 1982

South African Child Justice Act of 2008

South African Child Justice Bill of 2002

South African Constitution of 1996

South African Correctional Services Amendment Act of 1994 
South African Criminal Procedure Act of 1977

South African Probation Services Amendment Act 35of 2002 